\title{
PRELIMINARY EVALUATION OF ENVIRONMENTAL ISSUES ON THE USE OF PEAT AS AN ENERGY SOURCE
}
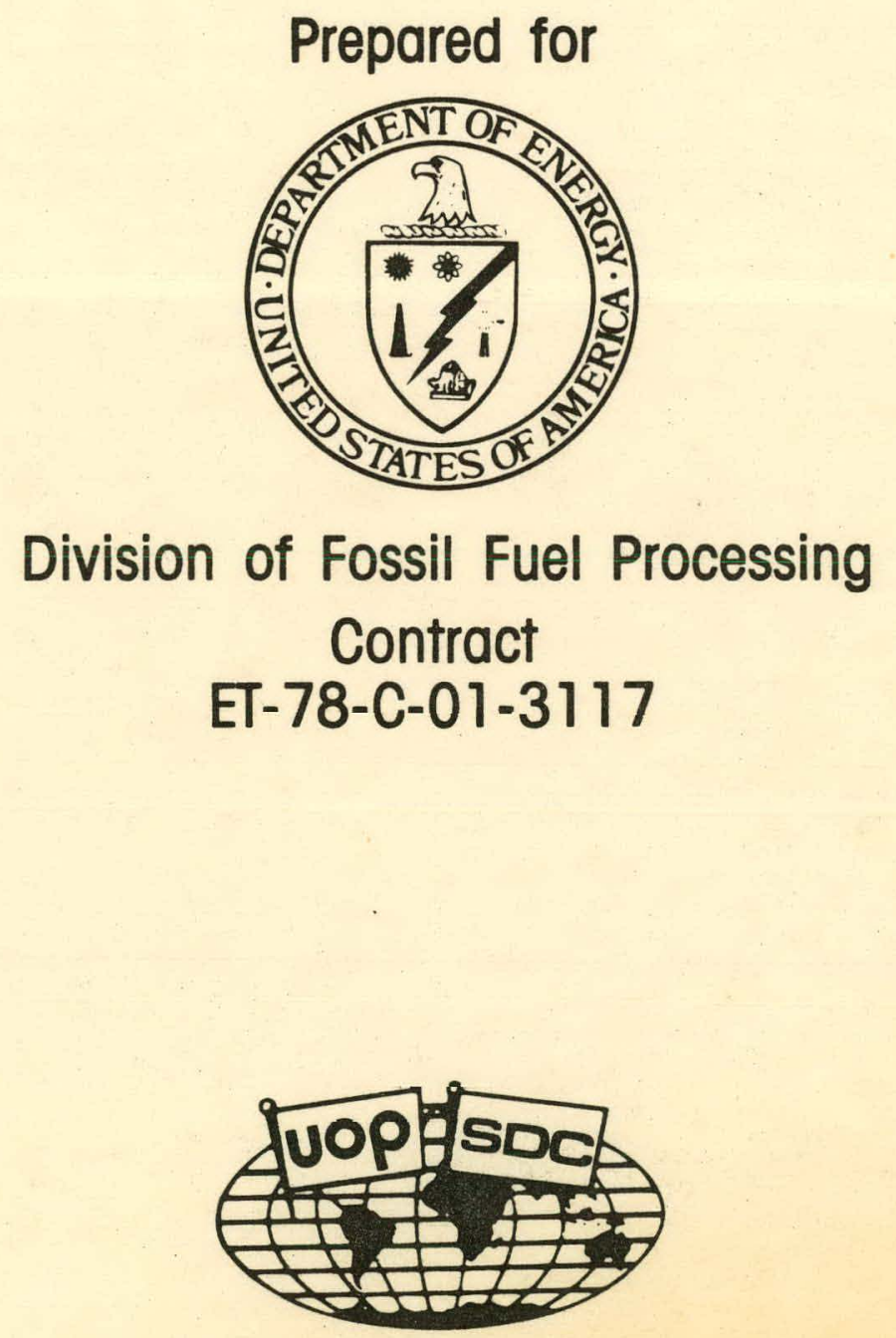

A JOINT VENTURE OF UOP INC. AND SYSTEM DEVELOPMENT CORPORATION 


\section{DISCLAIMER}

This report was prepared as an account of work sponsored by an agency of the United States Government. Neither the United States Government nor any agency Thereof, nor any of their employees, makes any warranty, express or implied, or assumes any legal liability or responsibility for the accuracy, completeness, or usefulness of any information, apparatus, product, or process disclosed, or represents that its use would not infringe privately owned rights. Reference herein to any specific commercial product, process, or service by trade name, trademark, manufacturer, or otherwise does not necessarily constitute or imply its endorsement, recommendation, or favoring by the United States Government or any agency thereof. The views and opinions of authors expressed herein do not necessarily state or reflect those of the United States Government or any agency thereof. 


\section{DISCLAIMER}

Portions of this document may be illegible in electronic image products. Images are produced from the best available original document. 


\section{DISCLAIMER}

This report was prepared as an account of work sponsored by the United States Covernment. Neither the United States nor the United States Department of Energy, nor any of their employees, makes any warranty, express or implied, or assures any legal liability or responsibility for the accuracy, completeness, or usefulness of any information, apparatus, product, or process disclosed, or represents that its use would not infringe privately owned rights. Reference herein to any specific commercial product, process, or service by trade name, mark, manufacturer, or otherwise, does not necessarily constitute or imply its endorsement, recommendation, or favoring by the United States Government on any agency thereof. The views and opinions of authors expressed herein do not necessarily state or reflect those of the United States Government or any agency thereof.

\section{PATENT STATUS}

This technical repult is being transmitted in advance of DOE patent clearance and no further dissemination or publication shall be made of the report without prior approval of the DOE Patent Counsel.

\section{TECHNICAL STATUS}

'This technical report is being transmitted in advance of DOE review and no further dissemination or publication shall be made of the report without prior approval of the DOE Project/Program Manager. 
PRELIMINARY EVALUATION OF ENVIRONMENTAL. ISSUES ON THE USE OF PEAT AS AN ENERGY SOURCE

\section{MASTER}

R. KING

S. RICHARDSON

A. WALTERS

L. BOESCH

W. THOMSON

J. IRONS

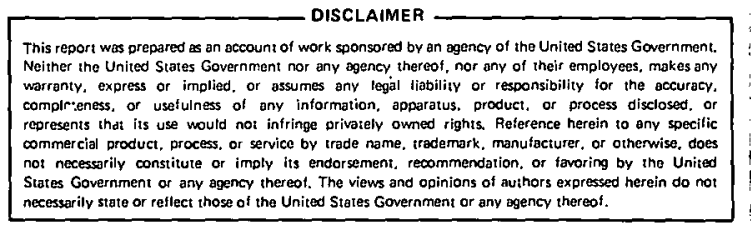

UOP/SDC, A Joint Venture

7929 Westpark Drive

Mclean, Virginia 22102

March 14, 1980

Prepared for the

United States Department of Energy

Division of Fossil Fuel Processing

Work Performed Under Contract No.

ET-78-C-01-3117 


\section{TABLE OF CONTENTS}

SECTION

PAGE

1 STUDY OBJECTIVES

2 OVERVIEW OF PEAT DEVELOPMENT

2.1 Introduction

2-1

2.2 Present Peat Utilization

2-1

2.3 Basic Technologies of Peat for Energy

2-3

2.4 Resource Extraction

2-9

2.5 Reclamation

2-17

2.6 Scales of Development

$2-20$

3 . ENVIRONMENTAL ISSUES

3.1 Introduction 3-1

3.2 Scope and Content of Issues . 3-1

3.3 Issue Identification $3-4$

3.4 Water Resource Issues . . . . 3-13

3.5 Water Quality Issues 3-21

3.6 Air Quality Issues 3-27

3.7 Aquatic Ecosystems Issues 3-37

3.8 Terrestial Ecosystem Issues 3-42

3.9 Health and Safety Issues 3-48

3.10 Regulatory Issues. 3-53

3.11 Solid Waste Issues 3-58

3.12 Secondary Devel opment Issues 3-60 
TABLE OF CONTENTS (continued)

4 STATE ANALYSIS

4.1 Introduction 4-1

4.2 Alaska 4-3

4.3 Minnesota 4-11

4.4 Wisconsin $4-15$

4.5 Michigan $4-20$

4.6 New York

4.7 Maine 4-31

4.8 North Carolina 4 4-37

4.9 South Carolina $\quad 4-42$

4.10 Florida $4-46$

4.11 Louisana $\quad 4-52$

5 UNIFORM DATA COLLECTION $5-1$

APPENDIX A - EXPANDED ISSUES AND DATA REQUIREMENTS

APPENDIX B - FEDERAL ENVIRONMENTAL LEĠİSLATION B-1

APPENDIX C - LIST OF PERSONS CONTACTED DURING STUDY

APPENDIX D - LETTER AND QUESTIONNAIRE . D-1

APPENDIX E - REFERENCES E-1

APPENDIX F - GLOSSARY OF TERMS F-1 


\section{LIST OF FIGURES}

Figure No.

Issues - Environmental

Issues - Socioeconomic

Issues - Constraints

Michigan Peat Resource Areas

Maine Peat Resource Areas

North Carolina Peat Resource Areas

Work Elements of the Peat Development 


\section{LIST OF TABLES}

Table No.

Title

Page

2.1

World Extraction of Peat

2-2

2.2

U.S. Peat Production 1977

$2-2$

2.3

Appropriate Harvesting and Energy

Conversion Technologies for Peat

2-6

2.4

Comparison of Peat Extraction Methods

$2-15$

Factors Governing Site Specific Reclamation

-

Urograms

2-18

2.6

250 MMscfd Pcat SNG Facility Requirements.

$2-23$

2.7

60 MW Peat Fired Power Plant Requirments

$2-25$

2.8

1 MW Peat Fired Steam Generator Facility

Requirements

$2-29$

3.1

Water Resource Environmental Issues

3-14

3.2

Water Quality Environmental Issues

$3-22$

3.3

Air Quality Fnvirnnment.al Issues

$3-28$

3.4

Aquatic Ecosystem Environmental Issues

$3-37$

3.5

Typical Terrestrial Resource Commitment for a 800 MW Power Plant

3.6

Terrestrial Ecosystem Environmental Issues

$3-11$

3.7

Health and Safety. Environmental Issue

3.8

Regulatory Environmental Issues

Alaska Peat Development Factors

4-6

4.2

Minnesota Peat Development Factors

4-12

4.3

Wiscuns in Peat Development Factur's

4-18

4.4

Michigan Peat Development Factors

$4-23$

4.5

New York Peat Development Factors

4-29 
4.6

4.7

4.8

4.9

4.10

5.1

5.2

5.3

5.4
Maine Peat Development Factors

4-34

North Carolina Peat Development Factors

$4-40$

South Carolina Peat Development Factors

$4-44$

Florida Peat Development Factors

4-49

Louisiana Peat Development Factors

Work Elements of the Peat Development

$$
\text { Environmental Program }
$$

$5-4$

Field Environmental Studies for Peat

Resource Development

$5-8$

Potential Sources of Local Instate

Environmental Data

$5-12$

Federal Agencies Principal 
AQCR

BACT

BOD

Btu

CEQ

$\mathrm{CO}$

$\mathrm{CO}_{2}$

COD

COE

$\cos$

$\mathrm{CS}_{2}$

CZM

CZMP

DOE

DOI

EIA

EIR

EIS

EO

[FA

FWPCA

$\mathrm{g} / \mathrm{dscm}$

$\mathrm{gr} / \mathrm{dscf}$

$\mathrm{H}_{2} \mathrm{~S}$

$\mathrm{hr}$

$1 \mathrm{~b}$

LNG

$M$

MM

MERRA

MW

Min

NAAQS
Air Quality Control Region

Best Available Control Technology

Bio-Chemical Oxygen Demand

British Thermal Unit

Council Environmental Quality

Carbon Monoxide

Carbon Dioxide

Chemical 0xygen Demand

Corps of Engineers

Carburlyl sulfide

Carbon Disulfide

Coastal Zone Management

Coastal Zone Management Program

Department of Energy

Department of Interior

Environmental Impact Assessment

Environmental Impact Report

Environmental Impact Statement

Emission offset

[nvironmental Protection Agency

Federal Water Poliution Control Act

grams per dry standard cubic meter

grains per dry standard cubic foọt

Hydrogen Sulfide

hour

pound

Liquefied Natural Gas

Thousand

Million

Michigan Energy Resource Research Association

Megawatt

Minute

National Ambient Air Quality Standard 


\section{GLOSSARY OF ABBREVIATIONS AND ACRONYMS (Continued)}

NEPA

NESHAP

NIOSH

NMHC

NO

$\mathrm{NO}$

$\mathrm{NO}_{2}$

NOAA

NSPS

OSHA

$\mathrm{PAH}$

PDU

Ppm

PSD

RCRA

ROW

scfd

SDWA

SIP

SNG

$\mathrm{SO}_{x}$

$\mathrm{SO}_{2}$

$\mathrm{SO}_{3}$

TSCA

TSP

USDA

USFWS

USGS

WRC
National Environmental Policy Act

National Emission Standards for Hazard Air Pollutant

National Institute of Occupational Safety and Health Non-Methane Hydrocarbon

Nitrogen Oxide

Nitrogen Oxides

Nitrogen Dioxide

National Oceanic and Atmospheric Administration

New Source Performance Standards

Occupational Health and Safety Act

Polynuclear Aromatic Hydrocarbon

Process Development Unit

parts per million

Prevention of Significant Deterioration

Resource Conservation and. Recovery Act

Right of Way

Standard Cubic Feet per Day

Safe Drinking Water Act

State Implementation Plan

Substitute Natural Gas

Sulfur Oxides

Sulfur Dioxide

Sulfur Trioxide.

Toxic Substances Control Act

Total Suspended Particulate

United State Department of Agriculture

United States Fish and Wildlife Service

United States Geological Survey

Water Resource Council 


\section{SECTION 1 - STUDY OBJECTIVES}

For centuries, peat has been an important source of fuel in a few areas of the World. Since the United States has substantial peat resources, interest has been expressed in the Congress and in the Executive Branch with regard to the possibility of using peat as a partial solution to our energy problems, particularly in regions that are otherwise poor in fossil fuels. At the request of. the Department of Energy, UOP/SDC has conducted a study to characterize the environmental issues, that would arise from an extensive peat utilization program.

This study is one of six project areas that DOE is currently pursuing in developing peat gasification technologies. The Federal peat program objective is... "to develop technologies for converting peat to substitute natural gas in an economical and environmentally acceptable manner." The program is intended to address the technical and environmental problems and issues that need to be resolved prior to the use of peat. As shown in Figure 1-1, work is under way in five of the project areas at this time. The Environmental Impact Assessment project consists of three phases; this study is the initial phase.

During this phase, scoping of the environmental issues has been completed. The environmental issues and concerns identified will be dealt with in detail during Phase II, when state and Federal interagency efforts will concentrate on data collection, data analysis, and further environmental research. Both the issue identification and data collection efforts will be directed ultimately at preparation of an Environmental Impact Assessment that will be completed during Phase II. Because of the variety of conditions and issues found within the... country, a number of generic peat utilization development schemes will be selected to evaluate environmental impacts on a local basis. 


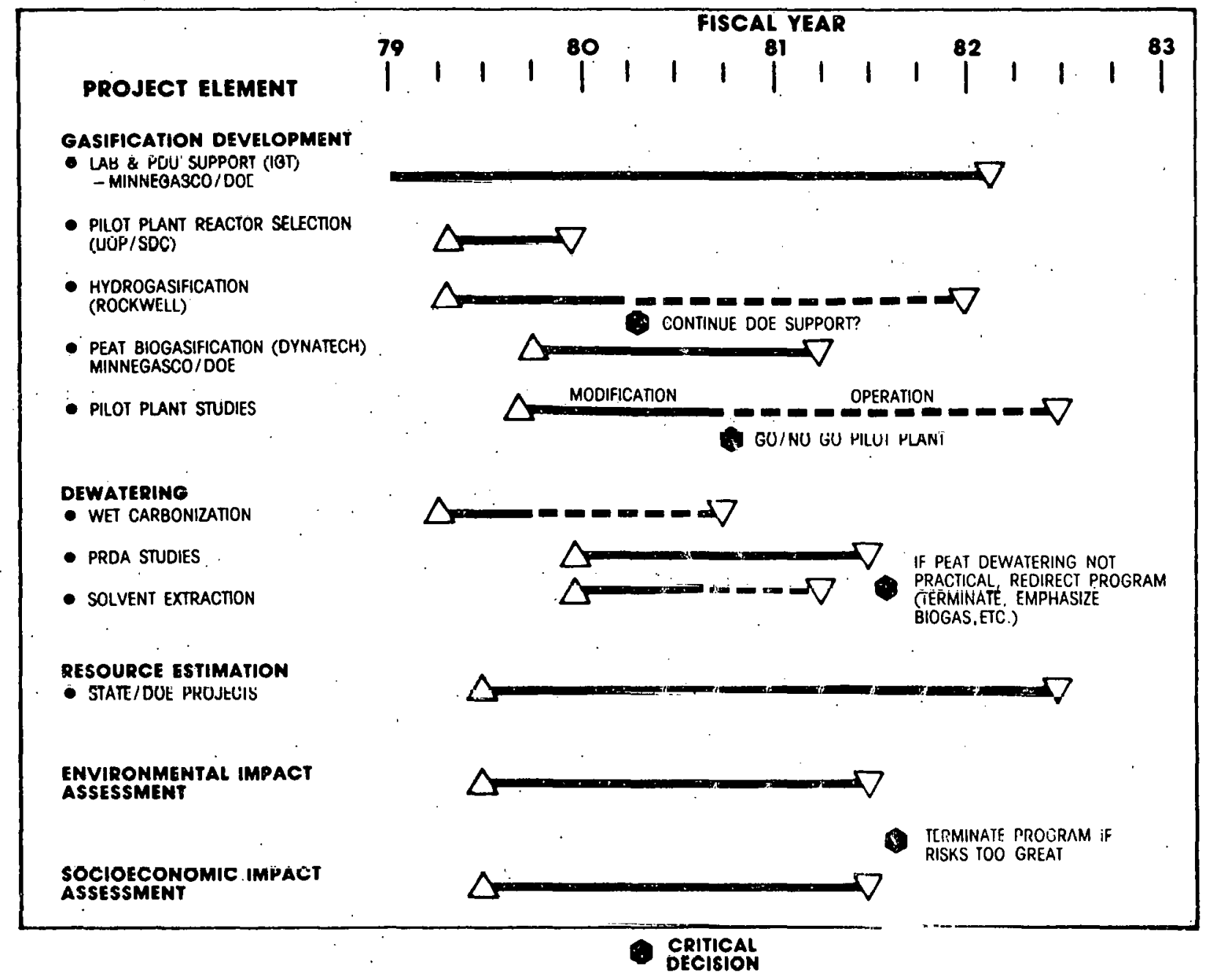

Figure 1-1 DOE Peat Program Milestones 


\subsection{STUDY OBJECTIVES}

If a major peat program is undertaken, the technologies that will need to be developed could have both immediate and long term effects on the socioeconomic and environmental values of a region. Early recognition of these effects will permit rational management and technical resource decisions to be made to deal with potential problems.

Accordingly, the objectives of this preliminary report are to:

- Identify the environmental issues and potential problems;

- Examine the significance of issues in the geographical regions where peat use could be developed; and

- Establish a methodology by which issues can be resolved or clarified through future coordinated private, state, and Federal programs.

In generating candidate peat development issues, UOP/SDC conducted literature searches and contacted state and Federal agencies that regulate the utilization of natural resources and energy development, potential energy developers, and special interest groups that are normally considered advocates of environmental protection. The resource and technical requirements for large-scale peat gasification facilities were analyzed, using available data, to identify potential problems that would ultimately become environmental issues if development were to occur.

For the purpose of this study, topics were identified as environmental issues when lhe response from contacts or analysis indicated that there was significant debate or controversy over the proper resolution. Identification of a topic as an issue does not necessarily mean that there is a negative or positive impact associated with it, but rather that no supporting consensus can be reached. For instance, a major issue would be determining the mix and 
allocation of alternative energy development schemes in a particular region. This issue is broad and covers many facets of energy, economics, policies, 'and technical and environmental factors for which neither negative nor positive benefits are clearly identified. However, many of the specific issues identified by this study are normally perceived by the individual or group contacted as potentially having an adverse impact on the natural environment. The following is a specific example of one of these issues: "Bog waters have a low pH, which may affect the water chemistry of the receiving watercourse if the bog is drained." This issue will remain unresolved until generic modeling and sitespecific research provide sufficient data to elucidate the complex effects, control strategies are developed to mitigate the negative aspecls, and regulatory processes are implemented to assure compliance.' Technical solutions to the issues raised do not necessarily mean a final resolution of the problem in the eyes of the public or local and state officials, so the opinion and views of the public will need to be considered thoroughly.

Issues will affect each person or set of interest groups differently, depending upon their economic, social, political, and environmental viewpoints. UOP/SDC makes no attempt to identify issues based upon changes in perceived trends, values, and public concern. The study was originally intended to identify the specific environmental issues involved in large-scale peat gasification development. This was broadened, however, at the directiun of the DOE Task Monitor to include issues involved in small and moderate scales of peat development. The environmental issues list that UOP/SDC has developed, though reasonably comprehensive, does not include all the complex and varied energy development environmental options, public preferences, and interests that exist. New issues will emerge as development becomes more site specific and closer to reality; therefore, the entire process must remain flexible enough to identify these new issues and to develop strategies for their resolution. In this study, UOP/SDC confined its attention to what appeared to be the most important issues and discussed them with key officials in Federal and state agencies and with representatives of environmental groups. The complex interrelationship of environmental concerns and energy requirements with economic and political factors was not studied in depth, although it is recognized that these factors must be taken into account before final policies are established for a peat utilization program. 
For the purposes of this study, it has been assumed that:

- Large-scale peat gasification facilities are technically feasible,

- Large-scale peat gasification facilities are economically feasible, and

- There is a need for energy from peat resources. 


\section{SECTION 2 - OVERVIEW OF PEAT-ENERGY DEVELOPMENT}

\subsection{INTRODUCTION}

With existing and new technology and appropriate national and state development programs, it appears that peat could be used to generate significant amounts of substitute natural gas (SNG), synthetic liquids, and electrical power to meet limited national and regional requirements. Within the peatland areas, peatgenerated electrical power could be readily distributed within the existing power grids to reduce the dependency on oil, meet future power demands, potentially reduce sulfur oxide air emissions, and use in-state energy resources. The use of peat for energy production.has been investigated by several natural gas and utility companies, with encouraging results. The energy production potential of peat-derived energy is clearly demonstrable; National, state, and local commitments are now necessary for prudent development.

\subsection{PRESENT PEAT UTILIZATION}

Although peatlands occur worldwide, only a few countries are currently extracting peat for energy or agricultural purposes. In particular, the Soviet Union and Ireland have extensive energy utilization programs for peat; they consume approxmately 95 percent and 2 percent, respectively, of the world's annual harvest (Table 2.1).(54) Also, Finland has embarked on a national effort to develop its peat resources for energy. Other countries that have used or are considering the greater use of peat are Germany, Holland, Great Britain, Scotland, Canadd, dind Sweden. $(54,55,69)$ Currently, no peat resources in the United States are used for energy production; however, there is substantial agricultural and horticultural peat production (Table 2.2). (78)

The worldwide utilization of peat resources has occurred on a scale ranging from individual Irish household users to the development of large Russian electric power generation facilities (up to $630 \mathrm{MW}$ ). Similar levels of development are potentially possible within the U.S. For this study, three development plans have been described to illustrate the importance of project scaling factors 
Table 2.1. World Extraction of Peat

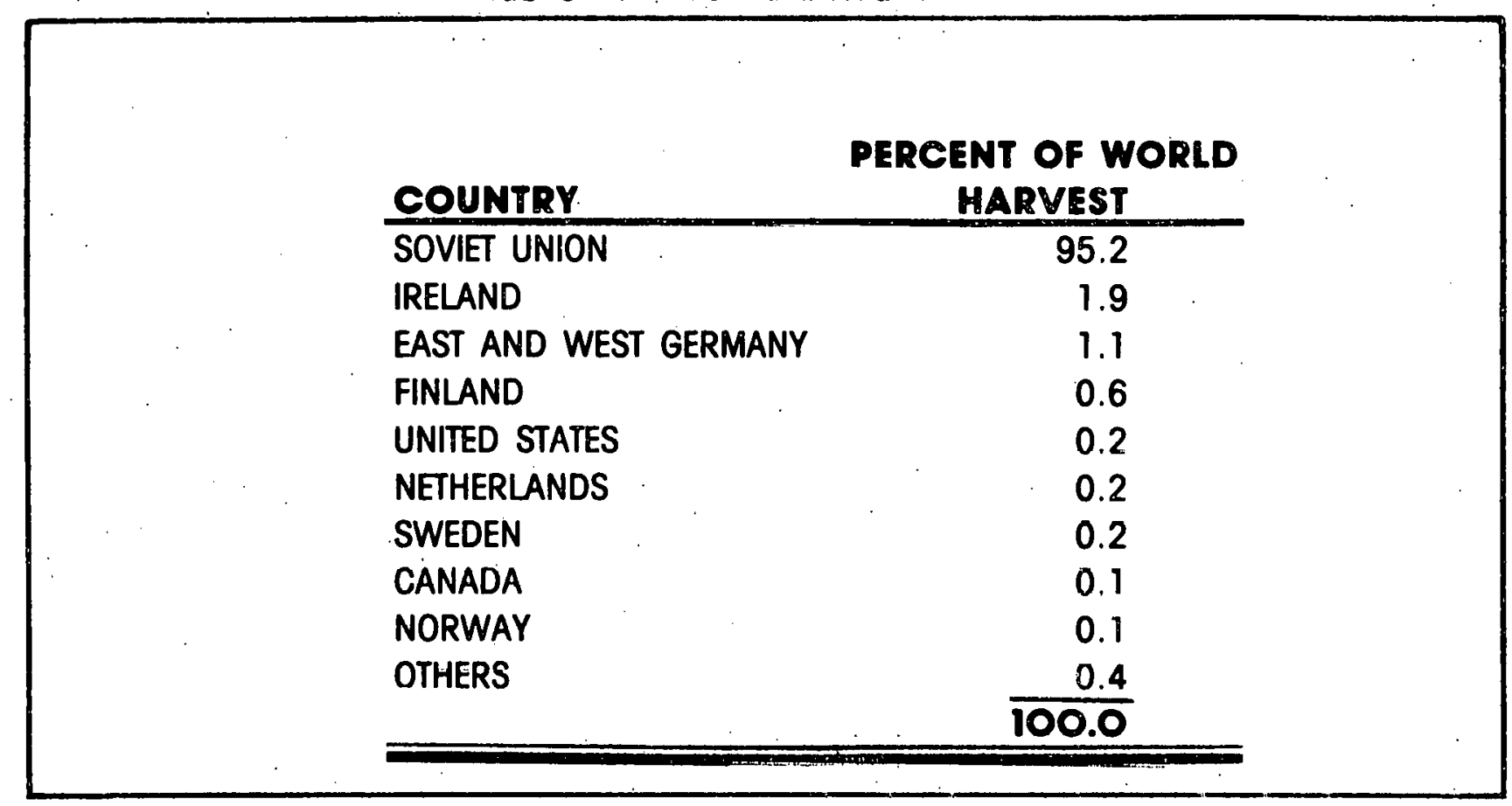

Table 2.2 Annual U.S. Peat Production 1977

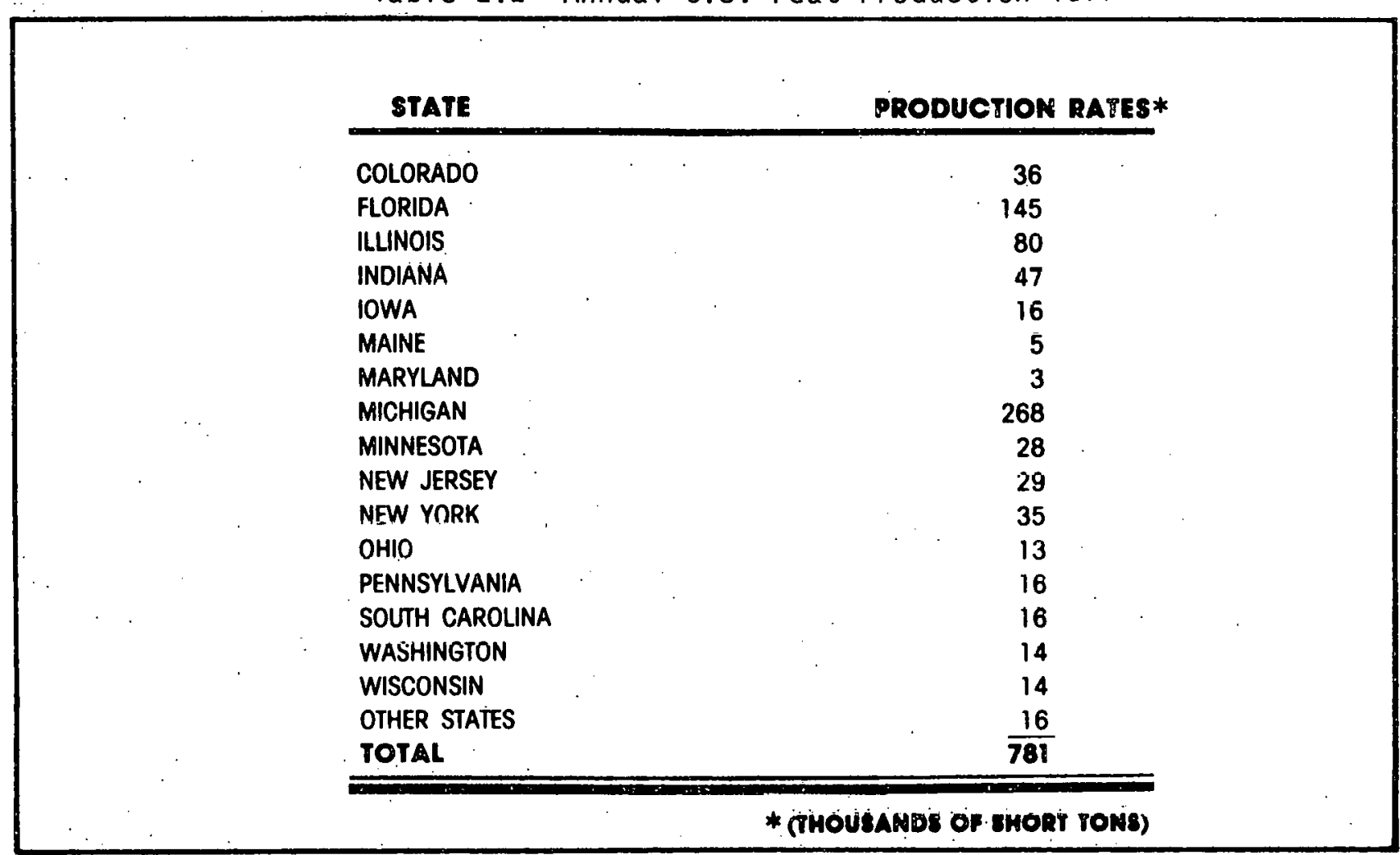


on environmental impacts and issues. The three potential schemes developed for the study are a $1 \mathrm{MW}$ steam facility, a $60 \mathrm{MW}$ electrical power plant, and a 250 MMscfd SNG facility. These projects span the foreseeable levels of U.S. peat development from the smallest to the largest peat energy facility.

The various aspects of peat resource development and utilization will be discussed in the following sections.

\subsection{BASIC TECHNOLOGIES OF PEAT FOR ENERGY}

Peat, as a very young form of coal, is a fossil fuel that can be used for energy in much the same manner as older lignite and subbituminous coal. It can be burned directly, after sufficient drying, or it can be converted to other fuels such as SNG. (51)

Because peat has lower energy content and a higher water content than lignite or subbituminous coal, it may be desirable to convert peat to higher energy content solid peat-fuel, which is similar to charcoal or to synthetic gaseous or liquid fuels. Peat-fuel is produced by high-temperature/high pressure chemical modification and beneficiation of peat through wet carbonization techniques to greatly reduce its inherent hydrophilic nature. Synthetic fuels can be produced from peat by liquefaction or gasification processes. (51)

Unlike more mature fossil fuels, peat can also be biologically converted to fuel gases. For this conversion, the hydrophilic nature of peat and its young age are advantageous. Anaerobic microorganisms can convert biologically digested peat into methane which can be separated as a fuel from byproduct.gases. (55)

The peat energy conversion product desired, along with the harvesting method selected, will determine the nature of the basic technologies required to convert peat into more useful fuel products. The need for and requirements of peat dewatering technology, for example, will depend entirely on these two factors. An energy-efficient technology for dewatering inined peat 
is one of the most significant technical requirements for the large-scale conversion of peat into liquid and gaseous fuels. (69).

\subsubsection{Dewatering}

Dewatering requirements of peat utilization for energy depend on the nature of the harvesting method selected and the energy conversion desired. A flow sheet illustrating alternative energy uses of peat is presented in Figure 2-1. The selection of both harvesting method and energy conversion technology depends, in turn, on the scale of intended operation. Table 2.3 lists the types of harvesting methods and energy conversion technologies appropriate to the three scales of operation chosen for this analysis.

Both medium-scale and large-scale operations must receive wet peat; only bioconversion to fuel gases will be able to use wet peat directly. Dewatering is necessary for peat gasification, liquefaction, or direct combustion on a medium or large-scale.

Natural peat contains about 90 percent water; as shown in Figure 2-2. The moisture level must be reduced at least to about 50 percent before it can be used as a feedstock to produce useful fuel products. This reduction in water content can be accomplished by variuus illedirs, including air-drying, wet carbonization, or solvent extraction. (51)

Air-drying typically involves harvesting by the milled-peat or sod-peat methods. These are described in Section 2.4. The long harvesting period, labor intensiveness and large surface extent of these two harvesting techniques makes them economically and environmentally unattractive compared to hydraulic or direct mining of wet peat.

Wet peat can be dewatered by thermal/oxidative destruction of its hydrophilic nature (wet carbonization) with some loss of its original energy content. Peatfuel, for example, is produced in such a high-pressure thermal process. These processes require mechanical filtration for final water separation. 


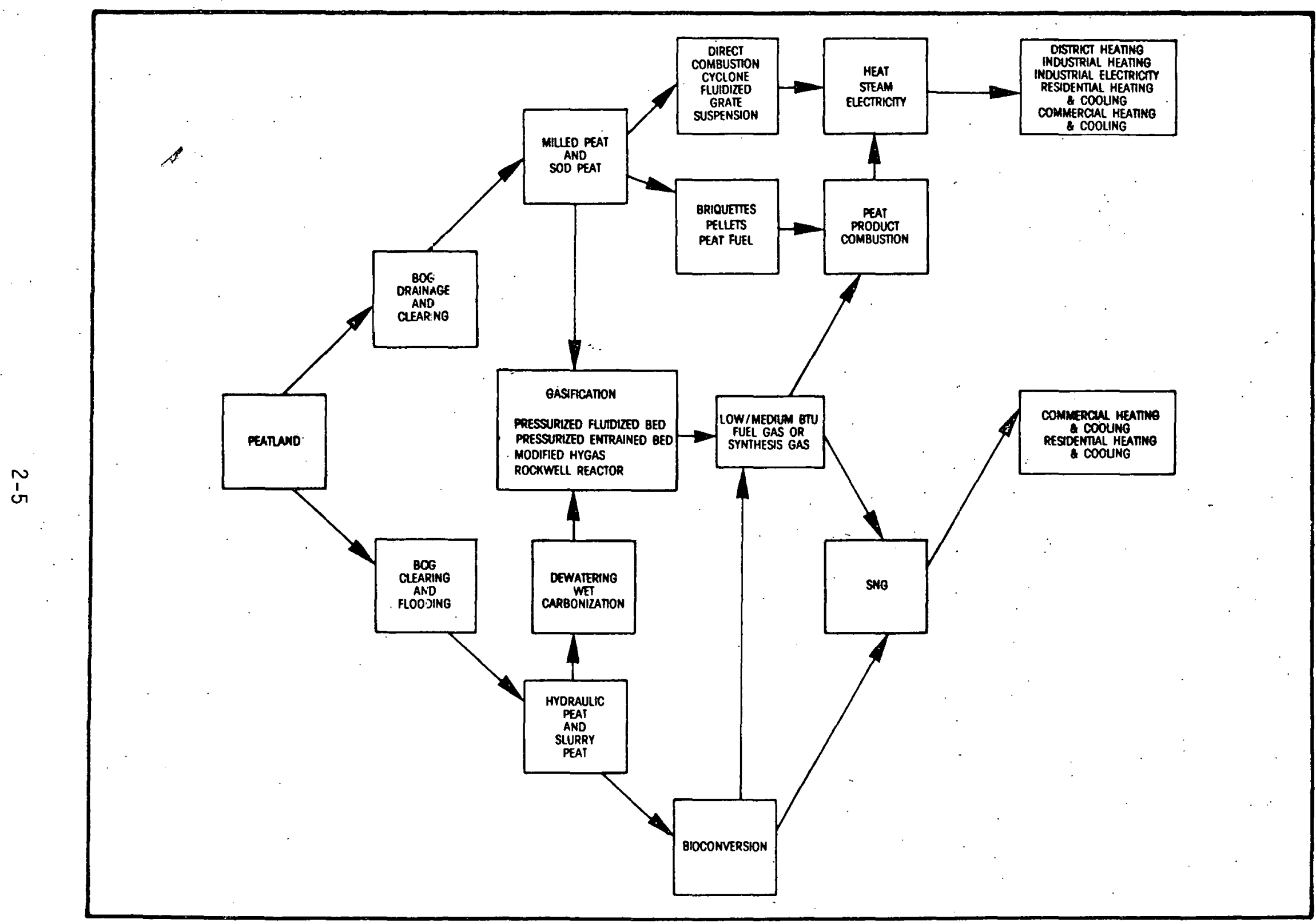

Figure 2-1 Alternative Energy Uses of Peat 
Table 2.3 Appropriate Harvesting and Energy Conversion Technologies for Peat

SCALE OF OPERATION

(MTOAWATts)

1 MW

$60 \mathrm{MW}$

$800 \mathrm{MW}$

(250 MMscfd)

\section{APPROPRIATE HARVESTING} TECHNOLOGIES

DIRECT, SOD, MILLED

HYRAULIC, DIRECT

MILLED, SOD
APPROPRIATE ENERGY CONVERSION TECHNOLOGY

DIRECT COMBUSTION FOR DISTRICT HEATING, WASTE INCINERATION, SMALL BOILERS
LOW/MEDIUM BTU FUEL GAS DIRECT COMBUSTION FOR STEAM-ELECTRIC POWERPLANT OR DISTRICT HEATING.

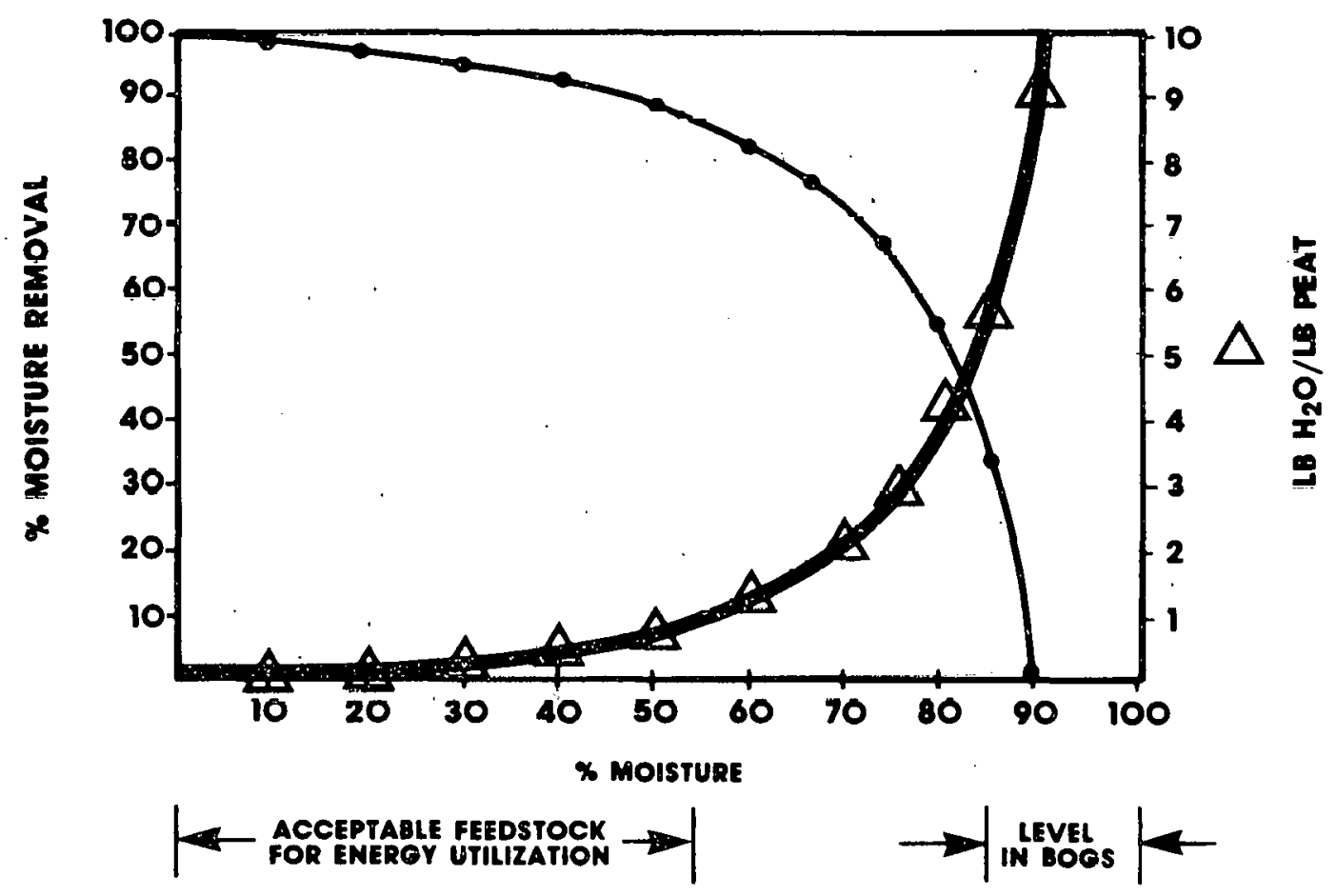

Figure 2-2 Moisture Levels in Peat

GASIFICAIION OR BIO. CONVERSION), LOW/MEDIUM BTU FUEL GAS, LUUEFACTION DIRECT COMBUSTION FOR STEAM-ELECTRIC POWERPLANT. 
Organic solvents can also be used to extract water from peat. This physical displacement takes place at elevated temperatures and pressures; the water is subsequently separated from the organic solvent at a reduced temperature.(51)

\subsubsection{Direct Combustion}

Direct combustion of air-dried peat from milled-peat or sod-peat harvesting is used to provide heat, steam, and/or electricity in several European countries. In some cases, the milled-peat or sod-peat is processed into briquettes or pellets that are also burned directly for energy.

Smal1-scale operations for the production of heat, steam, and/or electricity from direct combustion of local peat may be feasible in certain peat-rich areas in the United States that are lacking in local alternative energy resources. Air-dried peat is not suitable for transportation to energy markets over long distances because of its large bulk, relatively low energy content, and dustiness. Briquettes, pellets, and peat-fuel should be somewhat more transportable, but economics still will dictate consumption by the local energy market. (6.9)

Peat is typically lower in sulfur and higher in nitrogen than most coals. Its ash content depends upon the environmental conditions in which it is found, but fuel-grade peat will be relatively low in ash. Peat is highly reactive and will burn readily. Peat can be expected to burn with low sulfur oxide and particulate emissions. The relatively high nitrogen content of peat could lead to somewhat higher emissions of nitrogen oxides, but these emissions will depend also on other combustion parameters, such as water vapor level, flame temperature, and flame quenching at heat-transfer surfaces. $(54,55)$ Air quality issues are discussed further in Section 3.6 .

The scale of energy systems using direct combustion of peat range from home heating systems converted for sod-peat or solid peat-derived fuel use, through small-to-medium-scale steam generators for district heating, especially in newer, planned communities, to relatively large-scale steam electric power plants such as those in use in Europe. 


\subsubsection{Synthetic Liquid and Gaseous Fuels}

Peat is highly reactive in hydrogasification, pyrolysis, and biological conversion to fuel gases. It can be gasified to produce low/medium-Btu fuel gases or upgraded to high Btu pipeline quality SNG. Anaerobic biological conversion of digested peat to methane and carbon dioxide can also yield high-Btu fuel gases following separation of carbon dioxide and other byproduct gases from the raw methane-rich gas. Indirect liquefaction technologies are also available to produce a variety of synthetic liquid fuels frnm medium-Rtu synthesis gas. Direct conversion of peat to synthetic liquid fuels should be feasible, although very little effort has been expended to devel op suitable technology.

Tests at the Institute of Gas Technology have demonstrated the high reactivity and high overall conversion of peat during hydrogasification. Hydrogasification yields a gaseous fuel product suitable for use as a medium-Btu fuel gas, for upgrading to pipeline quality SNG, or for conversion to liquid fuels. Gasifier types suggested for hydrogasification include entrained flow and fludized bed types. $(46,47)$

Gasification of peat is similar to the gasification of coal with regard to the production of byproducts, such as the sulfur produced in acid gas removal and sulfur recovery operations necessary to reduce the sulfur content of product. fuel gas (the sulfur content of peat is typically low). Ash (residual inorganic matter left after the reactive carbonaceous material has reacted to form gaseous products) is removed from the bottom of the gasifier as a waste byproduct.

Unlike coal, peat can also be gasified biologically. Anaerobic microorganisms can convert aerobically digested peat into mainly methane and carbon dioxide. Predigestion by aerobic microorganisms breaks down cellulosic and lignitic components of peat that are difficult to convert under anaerobic conditions and facilitates anaerobic conversion to methane and carbon dioxide. A high quality methane-rich fuel results after carbon dioxide and other byproduct gases are separated from the raw product gas produced in the anaerobic bio-reactor. (51) 


\subsection{RESOURCE EXTRACTION}

This section of the study reviews the technical experience related to the extraction of peat by methods that appear technically attractive for energy programs. As used here, the term "extraction" comprises bog preparation and harvesting, transport, and storage of peat. Bog reclamation after peat harvesting is discussed in a later section.

\subsubsection{Bog Preparation}

The average water content of peat in a bog is approximately 94 percent, with amounts varying from 97 percent at the bog surface to about 90 percent in the lower portions of the bog. The specific gravity of bog peat typically averages only slightly more than that of water and remains nearly constant between 97 percent and 90 percent moisture content. Drying from 97 percent moisture to 90 percent moisture, can cause surficial peats to shrink by considerable amounts. The surface peat is the most recent deposition, least decomposed, and very fibrous in texture.

In all harvesting methods, except hydraulic harvesting, the peatland must be drained. Proçedures for bog drainage and drainage ditch patterns differ for sod-peat and milled-peat harvesting. Both of these methods require several seasons of succesively deeper, layer-by-layer harvesting of air-dried peat. Milled-peat production normally requires ditches to have closer spacing than does sod-peat harvesting, 50 feet apart versus 100 to 160 feet, respectively. The milled-peat ditches are usually 500 to 2,000 feet long between main drain pipes, whereas sod-peat areas may have ditch lengths of 250 to 800 feet. Typical for Ireland, the mininum sized milled-peat bog with gross area of 2,800 acres, has 2,100 acres usable for harvesting with the remainder being used for drainage, roads, turning areas, and storage. $(54,55,69)$

For milled-and sod-peat harvesting the shrinkage rate plays a direct role in determining the rate at which bog ditches can be deepened. As the water level in the bog lowers, the peat shrinkage proceeds slowly, since the fiber cells of 
the peat release water very slowly. The shrinkage limits the depth to which ditches can be initially dug and sequentially deepened. In Irish bogs, for example, the ditch is generally trenched initially to about four feet, and, after a year, about two feet per year, depending upon the peat stratigraphy, the drainage rate, and the rate of peat removal. (69)

Direct extraction also requires trenching, but the depth and spacing of trenches are determined by the depth and hydraulic characteristics of the peatland. In direct extraction, the full depth of peat is removed from the drained bog during the first pass through the area. The harvested peat is subsequently dewatered and processed at a separate location.

Hydraulic mining allows dredging of peat from a cleared but undrained bog. This eliminates much of the initial preparation and is limited to clearing surface vegetation and providing access. A floating dredge platform, along with maintenance of a static water level at or near the original peat surface, is necessary for hydraulic harvesting. (51)

This method is limited to peatlands which are depression deposits that can maintain the flooded condition; otherwise, an extensive dike system would have to be constructed to create the desired water level. On a moderately sloping bog used for large-scale development the frequent need to construct sufficient diking to maintain water levels could be expensive.

\subsubsection{Milled Peat Method}

The milled-peat harvesting method can be divided into the ridge peat and the vacuum peat method. These two methods use almost similar field processing methods but differ in their field collection methods and transporation schemes. The steps in this process are milling, harrowing, ridging, and collection. Milled-peat harvesting methods are based on the air drying of the upper inch of the peat horizon after the peat has been mechanically milled and harrowed in the field several times. The peat product is fine grained and has a mean moisture content of approximately 55 percent, ranging from 45 to 60 percent. 
This harvesting method removes the upper inch of peat during each harvest. The individual harvest will use several harrowings to dry the peat to the desired level. If rain should interrupt the field drying process, additional harrowing will be required. On an annual basis, this process can be used for approximately 40 days to 100 days, depending on local climatic conditions, and yield 10 to 20 harvests per season. In Ireland, 12 harvests are averaged each year. A peatland with nominal peat depth of six to seven feet would take four to five years to be harvested by the milled peat process. $(58,69)$

The annual milled-peat production rate from a given peatland will be principally governed by the climatic events. Finnish experience has indicated annual production rates of 388 tons per acre can be obtained, but only 73 tons per acre are harvested from the Irish deposits. The Irish, Finns, and Russians all have developed their own milled and harrowing machine designs. The design and field operation of the various milling schemes have only a small affect on the net drying rates in comparison to other large climatic variables, such as temperature, windspeed, precipitation, and relative humidity. Experience in Ireland indicates that the smallest bog practical for the milled-peat method contains 2,800 acres. By way of comparison, small horicultural milled-peat harvesting operations in Canada and the United States use less than 250 acres and produce between 50,000 to 100,000 cubic yards per year, requiring approximately 30 full time laborers. $(39,103)$ The European milling machines can generally harvest approximately 260 cubic yards per hour.

The principal drawbacks to milled harvesting system include the large bog area requirements, potential for bog fires, long duration of preemptive land use during harvesting, solid waste disposal problems during clearing operations, extensive, multiple operations prior to harvesting, decreasing bulk density, surface water runoff, intensive expenditure of manpower and equipment, weather dependency, fugitive particulate air pollution, and complex harvesting procedures. The main advantages of the milled-peat method are the superior fuel quality of the peat due to the lower water content and the relatively low energy requirements. (54) 


\subsubsection{Sod Peat Method}

The sod-peat harvesting method uses a specially constructed field machine excavator composed of a cutting head, mixer, macerator, and extrusion elements to form peat. The extruded peat sod varies from a cylindrical to a cubical shape depending on the extruder design. The sods are windrowed on the field for drying and then collected. A typical sod operation cuts down approximately five inches per harvest with three harvests per season. The windrowing is necessary to prepare the bog for the next harvest and to allow the peat to continue its drying process. The extruded peat sod cylinders or blocks are sufficiently waterproof that they do not increase appreciably in moisture content in a gentle rain. $(55,69)$

The windrowed sod is allowed to dry to approximately 50 to 75 percent moisture, which requires approximately 15 days, whereupon it is collected by a mobile conveyor system and deposited in large windrows or directly on a field transporter. Finnish production rates have been calculated to be on the order of 100 to 200 tons per acre over a 90-day harvest season. The Irish system allows several harvests per year; the season lasts from mid-March until the large rainfalls in July. The development of new windrowing (60 tons per hour) and collection (50 tons per hour) equipmęt. in Ireland and Finland has lead to higher production rates which reach approximately 200 cubic yards per hour. (55)

Ireland and Finland use different sod machines. The principal difference is that the Irish machinery uses a vertical bucket excavator and produces square blocks, whereas the new Finnish machinery uses a screw and disc cutter that produces a cylindrical peat. The major disadvantages of the Finnish machine are that tt does not mix the upper and lower horizons, as the Irish machine does, and is very suspectible to damage from rocks and stonnes. The major advantages of the Finnish design are simplicity of design and higher production speed. 
The disadvantages of the sod-peat method include the four-to five-year periods required to harvest an individual acre to a depth of 6 feet, high equipment and manpower expenditures, large land requirements, and need for extensive drainage systems. Its advantages over the milled method are slightly less peat bulking, longer harvest season, lower storage requirements, less wind drift, and generally less disruption from precipitation.

\subsubsection{Direct Extraction Method}

Direct extraction harvesting drains and excavates the entire peat column within one season. Conventional bucket and clamshell excavators, front end loaders, or slightly modified construction equipment are used to excavate and load the peat into surface transport or sluriry pipeline systems. To date, this method is used only by small operators who provide bulk horticultural and agricultural peat. The advantages of this system are larger production rates, less manpower and equipment, smaller land requirements, shorter time between clearing and rehabilitation, longer harvest season, and the potential for use of slurry transport. The disadvantages are poor equipment mobility in the wet environment, requirement for subsequent peat dewatering, and undemonstrated technical applicability for large operations.

\subsubsection{Hydraulic Harvest Method}

The hydraulic harvesting method, presently in the research stage, would use a barge mounted dredge, clamshell, or bucket dredge to load the peat into a peat slurry makeup tank; from which it would then be pumped by a slurry pipeline to a shore-based facility. It would be necessary to dewater the 3 percent solids slurry to the desired moisture content at the site of extraction or the processing facility.

The equipment for the barge and pipeline operations can be easily designed or modified from existing machinery and technology. However, the dewatering aspects have not been commercially demonstrated either by mechanical or thermochemical methods. Current dredge operations could be modified to harvest $1,000-75,000$ yards per day. 
The advantages of the hydraulic harvesting method would be a longer harvest season, insensitivity to weather conditions, less manpower and equipment required, simplified transportation system, and smaller annual land requirements. The principal disadvantages would be the requirement for subsequent dewatering, need for maintenance of a pool to float the equipment (which would also limit operation to specific types of bogs), and potential for increased contamination of peat with mineral soils.(51)

Current research on combined hydraulic dredging and dewatering is being conducted by the U.S. Bureau of Mines and Canadian concerns. Advanced European and Canadian air cushioned platforms àre being evaluated for application to peat harvesting. This could reduce the need for maintenance of a pool to float the equipment.

The four methods of peat extraction are compared in Table 2.4.

\subsubsection{Transportation}

The transportation requirements from the peatlands to a stockpile constitute a significant expense and mandate local use or conversion to other energy forms in most cases. Peat's low bulk density, and the seasonality of operation make final costs very sensitive to incremental transportation and storage costs. European experience for moderate size peat developments have indicated 50 mile haulages are the longest economically feasible. (58)

The peat transportation. systems commonly in use are specially designed field wagons, trucks, railroads, and slurry pipeline systems.

\subsubsection{Field Wagons}

In the case of milled-or sod-peat harvesting, field collection systems are designed for short hauls from the windrowed peat deposits across the surface to a transshipment field dump site. There are a number of wagon types, which 
Table 2.4 Comparison of Peat Extraction Methods

\begin{tabular}{|c|c|c|c|c|}
\hline $\begin{array}{l}\text { PRODUCTION } \\
\text { PARAMETERS }\end{array}$ & MILLED & SOD & HYDRAULIC & DIRECT \\
\hline $\begin{array}{l}\text { TECHNOLOGY } \\
\text { AVAILABILITY }\end{array}$ & PROVEN & PROVEN & UNPROVEN & UNPROVEN \\
\hline $\begin{array}{l}\text { HARVEST } \\
\text { METHOD }\end{array}$ & DRY & DRY & WET & WET/DRY \\
\hline $\begin{array}{c}\text { STORAGE } \\
\text { REQUIREMENTS }\end{array}$ & $\mathrm{HIGH}$ & $\mathrm{HIGH}$ & LOW & LOW \\
\hline $\begin{array}{c}\text { TRANSPORT } \\
\text { REQUIREMENTS }\end{array}$ & SURFACE & SURFACE & PIPELINE & PIPELINE/ SURFACE \\
\hline $\begin{array}{l}\text { LABOR } \\
\text { REQUIREMENTS }\end{array}$ & $\mathrm{HIGH}$ & $\mathrm{HIGH}$ & LOW & MODERATE \\
\hline $\begin{array}{l}\text { ENVIRONMENTAL } \\
\text { CONTROL } \\
\text { (WEATHER) }\end{array}$ & $\mathrm{HIGH}$ & $\mathrm{HIGH}$ & LOW & MODERATE \\
\hline $\begin{array}{l}\text { ANNUAL } \\
\text { COMMITMENT OF } \\
\text { LAND (AREA) }\end{array}$ & $\mathrm{HIGH}$ & $\mathrm{HIGH}$ & LOW & LOW \\
\hline
\end{tabular}


differ primarily in their loading and unloading mechanisms. The general capacity of these wagons is approximately 39 cubic yards and is limited by the need to achieve mobility in wet fields. $(55,69)$

\subsubsection{Trucking}

Truck transport is generally by single trucks or small truck and trailer combinations. The minimum practical size is approximately 39 cubic yards, the maximum, approximately 105 cubic yards. The containers must be completely enclosed to prevent wind loss and must be structurally stable against side wind loadings. Experience has indicated the trucks should not be so specifically designed that they cannot be used for other purposes during the nonharvest season. Finnish experience has noted that the approximate haul capacity of a truck trailer combination is about 102,000 cubic yards per season at a haul distance of 42 miles. $(39,36,59)$

\subsubsection{Railroad Transport}

Narrow, normal, and wide gauge railroads have been used for peat transport from remote bogs to a central storage or consumer facility. Rail transport lacks the flexibility of a truck haul system, but the economics and experience of the system warrant its consideration. The Finnish rail cars have a volume of 196 cubic yards; several designs are in use, with the basic differences being the unloading mechanisms. For a large-scale facility, shipping peat from a remote area by rail or, possibly, by slurry transport would be a necessity. $(39,55,69)$

\subsubsection{Slurry Transport}

The slurry transport of peat is in the early stages of development. Current small-scale projects, have demonstrated the feasbility of transporting a slurry of three percent solids at speeds of less than 15 feet per second. Major problems associated with slurry systems are the fluid properties of peat, which limit the solids concentration, and unsolved problems of peat dewatering on a large comnercial scale. Should these problems be solved, the economics and ease of slurry transport may prove attractive.(51) 


\subsubsection{Storage}

The storage of 85 to 270 days of reserves of milled-or sod-peat represents a. major commitment of land resource within the development area. Peat storage for a production facility is usually accomplished by the use of long-term field storage sites and short-term storage at the facility. Normally, field storage is designed to accommodate the entire year's production, whereas facility storage would normally hold a volume equal to two to five days of plant usage.

The European field stockpiles are arranged in rows in which the piles are approximately 12-16 feet high, 25 feet at the base, and 1/2 to 1 mile long. The piles are compacted and covered with polyethylene to reduce moisture buildup, prevent wind loss, and lower the potential for spontaneous combustion. The temperature within each pile increases due to slow oxidation and must be monitored to determine if steps need to be taken to prevent spontaneous combustion. Fuel quality within the pile generalily increases as a result of further moisture reduction of about 5 to 6 percent.

\subsection{RECLAMATION}

Reclamation of peatlands after harvesting will involve establishment of permanent drainage control, cleanup, and site conditions appropriate to the approved reclamation pian. The primary purposes of site reclamation will be to provide for long-term control of erosion and drainage and to mitigate the environmental and socioeconomic effects of the harvesting by improving the value of the land. By way of comparison, reclamation programs for oil shale and coal strip mines, are generally designed to create an initial vegetation cover, whereas peatland reclanation can be planned to support higher valued agricultural, silvicultural (forestry), recreational, and wildlife management programs.

The selection of the reclamation scheme for any specific peatland will, as indicated in Table 2.5, depend on such independent variables as scale of development, harvesting method, land ownership, future land use potential, post harvest site 
Tabie 2.5 Independent Eactors Governing Site Specific Feclamation Programs

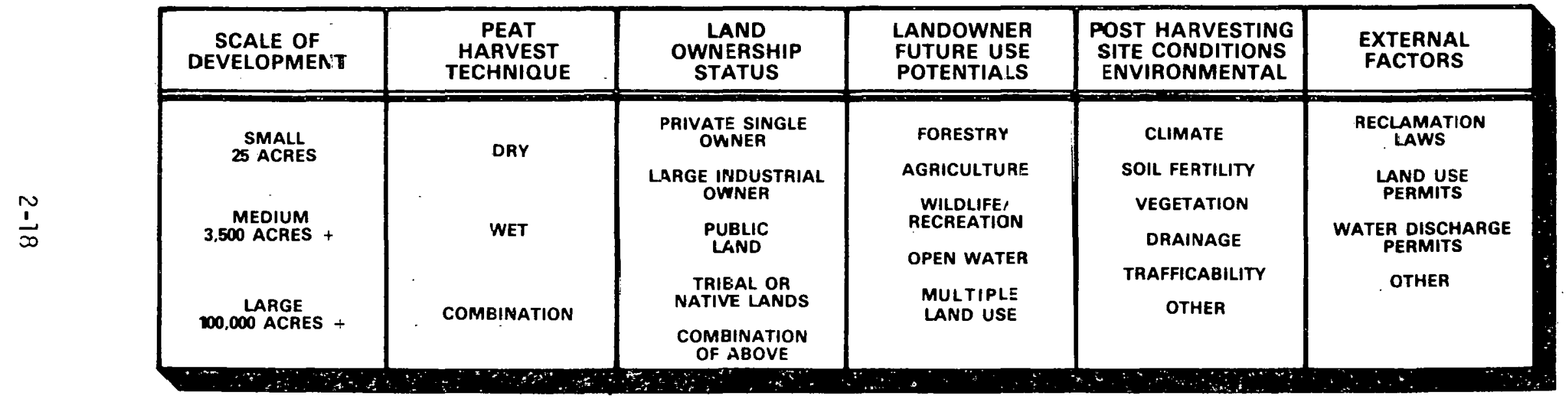


environmental conditions, and external factors which include primarily regulatory requirements and the desires of the public. Reclamation procedures for privately-owned land will reflect the landowner's desires but may be strongly affected by state and Federal reclamation laws and by state and local land-use plans.

It should be noted that reclaimed peatlands and associated muck deposits, if adequately drained, can have high economic value as exceptionally fertile agricultural or forest lands. In a similar manner, a carefully planned reclamation program can also create recreational and wildlife habitat values which are superior to those existing prior to harvesting. Consequently, it can be expected that there will be competition among various interests for any publicly owned reclaimed lands created after moderate- or large-scale harvesting operations have been completed. The conflicting goals of these competing interests must be resolved prior to the initiation of development.

The site specific technological and environmental conditions of the bog will determine whether wet (hydraulic) or dry (drained bog) harvesting techniques are selected. This choice will have a major impact on future options for reclaimed land use.

Use of the dry harvesting methods requires that the site be artificially drained by an extensive ditching program. Consequently, a site for which dry harvesting is selected must be one that has a terrain conducive to ditch drainage or one that can be economically drained by pumping. After harvesting, the harvest area will consist of a well drained fertile landscape that will be amenable to a variety of uses. These land uses include intensive forestry, agriculture, recreation, wildlife habitat development, or a combination of the above uses.

In comparison, a site selected for hydraulic peat extraction must be one that can be controlled to allow the construction of a shallow lake to support the harvesting machinery and the slurry pipeline. After the peat has been hydraulically harvested, the area will be either a shallow body of water or appearing as a poorly drained semiemergent landscape. 
Similar land uses can be established for hydraulically harvested areas iff drainage systems are established, but, if a water body is established, area options would be directed at developing enhanced ripanian wildlife habitat, growing selected agricultural crops (such as wild rice), or promoting recreational activities.

The prinicipal natural environmental features that would affect the reclamation options are the seasonal fluctuations in groundwater level, soil fertility and drainage characteristics, amount of residual peat, trafficability, access, and the number and types of streams and lakes. The option selected must be one that is consistent with these local parameters.

\subsection{SCALES OF DEVELOPMENT}

As previously discussed, the range of meaningful peat development options can be covered by considering a large-scale gasification facility (250 MMscfd SNG), a moderate size electrical generating plant (60 MW), and a small size steam facility $(1 \mathrm{MW})$. The size of any proposed facility will be limited by the nature and extent of the local peat resource. For any "minemouth" energy project, as the size of the processing facility increases, the ability to supply adequate sources of feedstock becomes critical and limiting to the system. This especially true with peat energy development, which is currentiy labor, land, equipment, and capital intensive.

Peat harvesting, in comparison to other energy production processes, is much more heavily influenced by meteorological and other dynamic environmental parameters and consequently is more subject to environmental risks that could limit energy production. For example, if the harvesting season is shortened by an early or late freeze, excess precipitation, or late snows or thaw, it may not be possible to meet production requirements unless equipment and manpower can be quickly auginented. In no other energy industry does climate have such a lynamic imlact on resource production. 
The largest foreseeable U.S. peat conversion facility is the 250 MMscfd SNG plant presently being proposed by the Minnesota Natural Gas Co. The peat feedstock requirement for this facility is roughly equivalent to that for a $800 \mathrm{MW}$ electrical power plant. Approximately 125,000 acres of peat would be required to supply this facility for a 20-year period. (46) The only comparable peat energy development system to this plant is a $630 \mathrm{MW}$ peat-fired electrical power plant complex operating in Russia.

This large allocation of land resources would make this plant one of the largest energy production facilities within the United States. Such a development could lead to farfield impacts because of the size of land area. The peat site would need to be centrally located within the controlled area of peat harvesting to reduce overall transportation costs and logistic complexities. The approximate siting of the facility would be almost automatic once the limits of peat development area were defined.

The moderate sized peat energy facility is a $60 \mathrm{MW}$ peat-fired electrical power plant. Similarly sized peat energy facilities are widely used in Ireland, Finland, and Russia. $(55,69)$ Over a twenty-year operational life, the facility would use approximately 3500 acres of peat at a depth of six feet from one or several peat bogs. The moderate sized facility, in comparison to the large SNG facility, could use more limited peat resources from several adjacent bogs. An individual facility of this size would not be expected to generate major farfield impacts. The local employment and economic system would be stimulated by the development, and no major boom or busts or infrastructure impacts would be foreseen from this moderate scale of development (refer to RADIAN study for more information). The energy produced from this facility could be used in local municipal areas or industries to provide local energy supplies and to stimulate the overall economic and industrial prospects of an area.

The smallest commercial peat development scheme envisioned is a 1 MW-equivalent peat boiler producing steam.and heat for a small industrial, military, or municipal complex. This small facility would consume 26 acres of peat, at a mean depth of six feet, over a 20 year plant life. The impacts from this facility 
would be localized and very. easily controlled. A peat boiler of this size could be fabricated at a factory, shipped directly on the site, and installed with minimal skilled labor.

The environmental issues and concerns that can be expected to arise from the various scales of development are identified in section 3.

\subsubsection{Large-Scale Development: 250 MMscfd SNG Facility}

In addition to the cost of the facility itself, the development of a large peat facility for either gasification or electric generation will require large capital and manpower expenditures for the harvesting, transportation, dewatering, and storage of peat. As shown in Table 2.6, the seasonal aspects of a particular harvesting scheme, the manner of field development, and means of transportation could vary widely for the same annual production rate and thus create large variations in the equipment and manpower required.

Also shown in Table 2.6 are some of the factors that must be considered in determining the environmental impacts of harvesting. It should be noted that, whatever the method selected, a total of 125,000 acres must be harvested to a depth of six feet over the 20-year life of the facility. Because of it.s magnitude, it appears probable that the environmental problems related to the harvesting operation well be more difficult than those resulting from the conversion process. $(46,47)$ It can be expected that the implementation of a largescale program in any of the few states having the extensive peat resource needed for its support could begin only after lengthy site-specific environmental analyses had been completed.

\subsubsection{Moderate-Scale Development: 60 MW Peat Fired Electrical Power Plant.}

Moderate-sized, peat-fueled powerplants are currently in operation in Ireland, Finland, and Russia. Some of these plants have provided over 20 years of reliable electrical service at costs competitive with those of oil-and coalfueled facilities. $(54,55)$ The technology for these facilities is well-known, 
Table 2.6 250 MMscfd Peat SNG Facility Requirements

(page 1 of 2)

Daily Btu Input:

$480 \times 10^{9} \mathrm{Btu}$

Total Peat Requirement: 125,000 Acres with 6 Foot Depths

\begin{tabular}{|c|c|c|c|c|}
\hline HARVEST METHOD & ILLED PEAT & SOD PEAT & HYDRAUL IC & $\begin{array}{l}\text { DIRECT } \\
\text { EXTRACTION }\end{array}$ \\
\hline \multicolumn{5}{|l|}{ DEVELOPMENT } \\
\hline $\begin{array}{l}\text { Annual Resource } \\
\text { Commitment (Acres) }\end{array}$ & 30,000 & 30,000 & 6,400 & 6,400 \\
\hline $\begin{array}{l}\text { Mining Duration in One } \\
\text { Area (Years) }\end{array}$ & $4-5$ & $4-5$ & $1 / 2$ & $1 / 4$ \\
\hline $\begin{array}{l}\text { Time From Clearing to } \\
\text { Reclamation (Years) }\end{array}$ & 9 & 9 & 2 & 1 \\
\hline \multicolumn{5}{|l|}{ HARVEST } \\
\hline Daily Harvest (Acre Feet) & 416 & 312 & 144 & 133 \\
\hline $\begin{array}{l}\text { Length of Annual Harvest } \\
\text { Season (Days) }\end{array}$ & 90 & 120 & 260 & 280 \\
\hline $\begin{array}{l}\text { Harvested Area \& } \\
\text { Ancillary Features } \\
\text { (Acres/Year) }\end{array}$ & 30,000 & 30,000 & 6,250 & 6,250 \\
\hline $\begin{array}{l}\text { Number of Harvest } \\
\text { Operations }\end{array}$ & 4 & 3 & 1 & 1 \\
\hline $\begin{array}{l}\text { Harvestor Requirements } \\
\text { (Number of Pieces) }\end{array}$ & 136 & 111 & 9 & 30 \\
\hline $\begin{array}{l}\text { Depths of Individual } \\
\text { Harvest }\end{array}$ & 1 inch & 5 inches & 6 feet & 6 feet \\
\hline $\begin{array}{l}\text { Number of Harvests Per } \\
\text { Year }\end{array}$ & 16 & 3 & 1 & 1 \\
\hline
\end{tabular}


Table 2.6 250 MMscfd Peat SNG Facility Requirements (page 2 of 2 )

HARVEST METHOD
DRAINAGE REQUIREMENTS

Additional

First Year Discharge
(Acre Feet)
Additional Second
Year Discharge

(Acre Feet)

Net Water Discharge (Percent)

Field Pumpage

Requirements

Water Controls
36,000

MILLED PEAT

SOD PEAT

36,000

Water Rqd

for Slurry

Approx' 1y

Normal

Runoff

Approx
Normal
Kunott

35

$45-50$

May Be

Rqd.

Cannot $\mathrm{Be}$

Centralized

HYDRAUL IC

May Be

Rqd.

Rqd. for

Slurry

Cannot Be Diking to

Centralized Control Water

DIRECT

EXTRACTION

11,700

$11,7 n 0$

30

May Be

Rqd.

Several

Treatment

Facilities

per Year

Rqd.

Bog Constraints

+ must be urianable

- must create a pool

\section{OTHER REQUIREMENTS}

\begin{tabular}{|c|c|c|c|c|}
\hline $\begin{array}{l}\text { Annual Storage } \\
\text { Requirement (Days) }\end{array}$ & 270 & 245 & 105 & 85 \\
\hline $\begin{array}{l}\text { Daily Transportation } \\
\text { Trips to Stockpiles } \\
80 \text { Yards }{ }^{3} \text { Trucks } \\
7400 \text { Yards }{ }^{3} \text { Trains }\end{array}$ & $\begin{array}{r}9101 \\
97\end{array}$ & $\begin{array}{r}6826 \\
72\end{array}$ & Slurry & $\begin{array}{r}2925 \\
1\end{array}$ \\
\hline
\end{tabular}


Table 2.7 60 MW PEAT FIRED POWER PLANT REQUIREMENTS.

(page .1 of 2)

Daily Btu Input: . . $129 \times 10^{8}$ Btu

Total Peat Requirement: 3640 Acres with 6 foot Depth

\begin{tabular}{|c|c|c|c|c|}
\hline HARVEST METHOD & MILLED PEAT & SOD PEAT & HYDRAUL IC & $\begin{array}{l}\text { DIRECT } \\
\text { EXTRACTION }\end{array}$ \\
\hline \multicolumn{5}{|l|}{ DEVELOPMENT } \\
\hline $\begin{array}{l}\text { Annual Resource } \\
\text { Commitment (Acres) }\end{array}$ & 912 & 912 & 182 & 182 \\
\hline $\begin{array}{l}\text { Mining Duration in One } \\
\text { Area (Years) }\end{array}$ & $4-5$ & $4-5$ & $1 / 2$ & $1 / 4$ \\
\hline $\begin{array}{l}\text { Time From Clearing to } \\
\text { Reclamation (Years) }\end{array}$ & 7 & 7 & 1 & 1 . \\
\hline \multicolumn{5}{|l|}{ HARVEST } \\
\hline Daily Harvest (Acre Feet) & 12 & 9 & 4.2 & 3.9 \\
\hline $\begin{array}{l}\text { Length of Annual Harvest } \\
\text { Season (Days) }\end{array}$ & 90 & 120 & 260 & 280 \\
\hline $\begin{array}{l}\text { Harvested Area } \\
\text { (Acres/Year) }\end{array}$ & 912 & 912 & 182 & 182 \\
\hline $\begin{array}{l}\text { Number of Harvest } \\
\text { Operations }\end{array}$ & 4 & 3 & 2 & 1 \\
\hline $\begin{array}{l}\text { Harvestor Requirements } \\
\text { (Number of Pieces) }\end{array}$ & 3 & 2 & 1 & 1 \\
\hline $\begin{array}{l}\text { Depts of Individual } \\
\text { Harvest }\end{array}$ & 1 inch & 5 inches & 6 feet & 6 feet \\
\hline $\begin{array}{l}\text { Number of Harvests Per } \\
\text { Year }\end{array}$ & 16 & 3 & 1 & 1 \\
\hline
\end{tabular}


Table 2.7 60 MW Peat Fired. Power Plant Requirements (page 2 of 2)

\begin{tabular}{|c|c|c|c|c|}
\hline HARVFST METHOD & IIIED PFAT & EAT & $\begin{array}{c}\text { HYDRAULIC } \\
\text { MINING }\end{array}$ & $\begin{array}{l}\text { DIRECT } \\
\text { EXTRACTION }\end{array}$ \\
\hline & LLEU PEAI & EH & & \\
\hline
\end{tabular}

\section{DRAINAGE REQUIREMENTS}

Additional First Year Discharge

1280 1282

Water Rqd. 364

(Acre Feet)

Additional second Year Discharge
(Acre Feet) Normal Normal Waler Rqd. 364

Net Water Dịscharge (Percent)

Field Pumpage Requirements $45 \cdot-50$ 35

0 30

Water Controls

General ly

Rqd.

Can be centralized

\section{Generally}

Rqd.

Can be centralized will require slurry pumps

Diking and water control required
Generally Rqd.

Can be centralized

Bog Constraints

+ must be drainable

- must create a pool

\section{OTHER REQUIREMENTS}

Annual Storage

Requirement. (Days)

Daily Transportation

Trips to Stockpiles 80 Yards $^{3}$ Trucks 7400 Yards $^{3}$ Trains
275

200

2.1

245

105

85

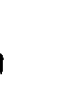

(n)

.

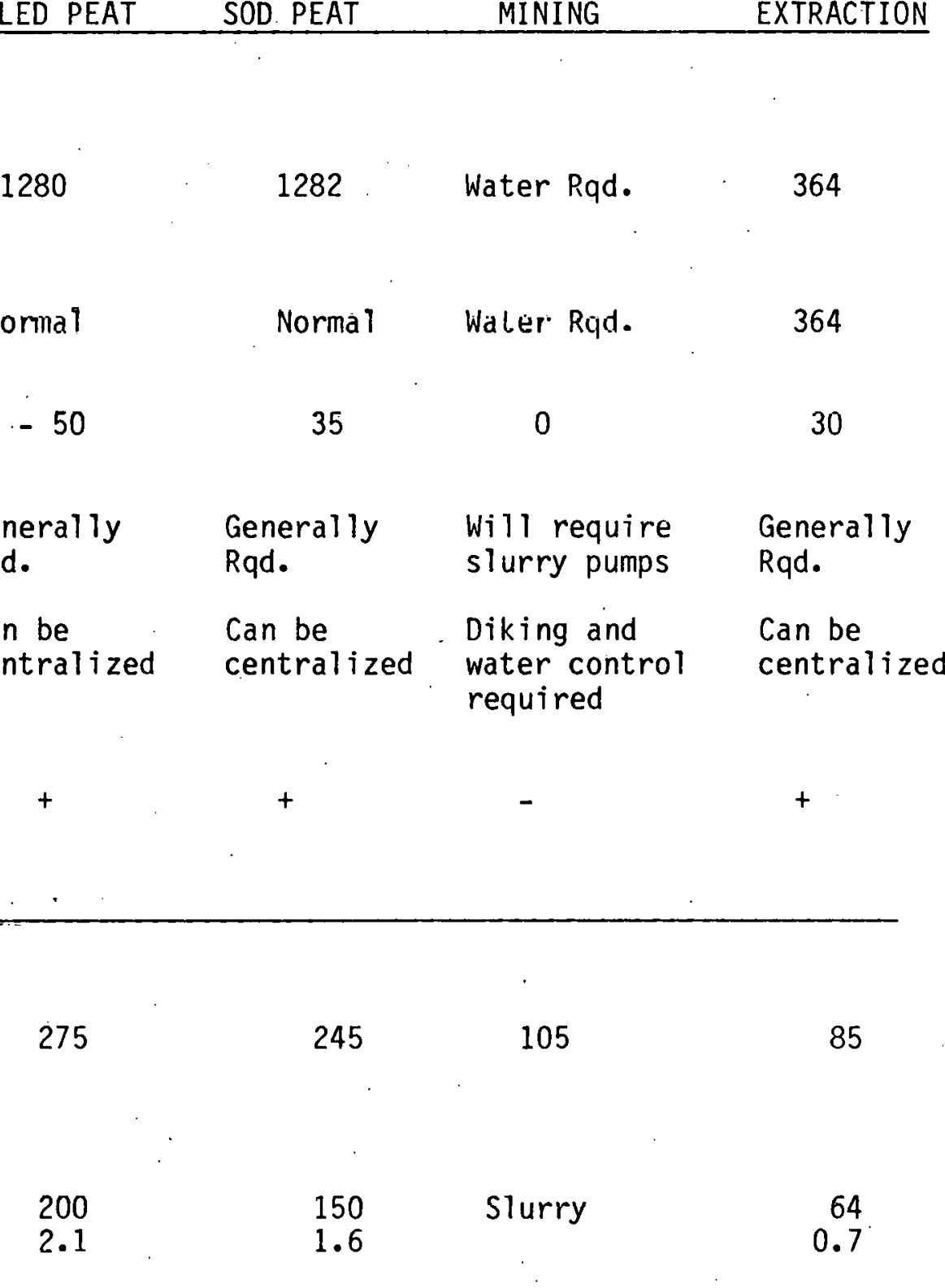


and various designs that have operated successfully for many years are available. Although $60 \mathrm{MW}$ facility is small in comparison to new coal and nuclear electric generating power plants, it appears to be a practical size for a peat-fired plant to be used in areas that have limited or scattered peat reserves.

Over a twenty-year period, a $60 \mathrm{MW}$ facility would require 3500 acres of peat at an average depth of six feet (see Table 2.7). These resources could be gathered from a single peatland or from a number of small bogs. Water quality and drainage control systems could be easily developed at this small scale to preclude major offsite impacts. With adequate drainage provided during the harvesting phase, the reclamation of the harvested areas for agricultural, forestry, wildlife, or recreational pursuits should be relatively simple.

European experience indicates that a peat-fired facility would cost approximately one-third more than an oil-fired facility of similar capacity. (59) The increased costs in Europe are due to the need for increased boiler capacity and more materials handling equipment. Although these requirements would also apply to a plant in the U.S., their cost might be partially offset by the lowered cost of air pollution controls as the result of the lower sulfur concentration in the fuel. In comparison to coal, the use of peat for fuel would not yield as much solid waste from land clearing and overburden removal but might create more waste ash:

On an overall energy basis, the development of 10 to 20 of these facilities in sparsely populated areas of northern and southeastern regions and Alaska would not constitute a major national energy source. However, they would help meet the energy needs of these remote areas and provide an economic stimulus.

\subsubsection{Small-Scale Development: 1 MW Steam Boiler}

The small-scale use of peat for energy is intended to provide heat and steam for small public, municipal, or industrial centers. Small boilers of this capacity are currently in wide use. Boiler fireboxes could be retrofitted to accept peat or new, redesigned boilers could be installed at existing and future 
centers. As shown on Table 2.8, peat requirements to operate a single facility for 20 years are approximately 25 acres at six foot depth. Such peat resources are readily available in many states and could provide a suitable fuel source for a restricted level of development. European economic experience indicate that the milled, sod, and hydraulic peat harvesting methods would be expensive for this low level of development. However, available equipment could be used for direct extraction at relatively low cost. This method is now being used for harvesting peat for horticultural use.

Rniler and peat handling systems could be designed for rapid onsite fabrication by a minimum of skilled labor. The benefits from such use of peat would be local control over fuel prices and independence from external fuel supplies. The impacts and benefits of the small-scale development would be very localized and not expected to warrant a major state or Federal environmental impact analysis. $(94 ; 103)$

In most cases, it is expected that it will be practical to have the boiler at some distance from the peat harvest sites if necessary. Transportation and storage requirements for the amount of peat to be used should not be difficult to meet. 
Table 2.8 1 MW Peat Fired Steam Generator Facility Requirements (page 1 of 2)

Daily Btu Input: $\quad 117 \times 10^{6}$ Btu

Total Peat Requirement 26 Acres with 6 Foot Depths

\begin{tabular}{llll} 
HARVEST METHOD & MILLED PEAT SOD PEAT HYDRAULIC & DIRECT \\
\hline
\end{tabular}

\section{DEVELOPMENT}

\begin{tabular}{|c|c|c|c|c|}
\hline $\begin{array}{l}\text { Annual Resource } \\
\text { Commitment (Acres) }\end{array}$ & 6.5 & 6.5 & $\begin{array}{l}\text { Not practical } \\
\text { with this scale } \\
\text { of development }\end{array}$ & 1.3 \\
\hline $\begin{array}{l}\text { Mining Duration in One } \\
\text { Area (Years) }\end{array}$ & 5 & 5 & $"$ & 1 \\
\hline $\begin{array}{l}\text { Time From Clearing to } \\
\text { Reclamation (Years) }\end{array}$ & 6 & 6 & " & 1 \\
\hline \multicolumn{5}{|l|}{ HARVEST } \\
\hline Daily Harvest $\left(\right.$ Yards $\left.{ }^{3}\right)$ & 138 & 104 & $"$ & 45 \\
\hline $\begin{array}{l}\text { Length of Annual Harvest } \\
\text { Season (Days) }\end{array}$ & 90 & 120 & $"$ & 280 \\
\hline $\begin{array}{l}\text { Harvested Area } \\
\text { (Acres/Year) }\end{array}$ & 6.5 & 6.5 & $"$ & 1.3 \\
\hline $\begin{array}{l}\text { Number of Harvest } \\
\text { Operations }\end{array}$ & 1 & 3 & $"$ & 1 \\
\hline $\begin{array}{l}\text { Harvestor Requirements } \\
\text { (Number of Pieces) }\end{array}$ & 1 & 1 & $"$ & 1 \\
\hline $\begin{array}{l}\text { Amount of Individual } \\
\text { Harvests }\end{array}$ & 1 inch & 5 inches & $"$. & 6 feet \\
\hline $\begin{array}{l}\text { Number of Harvests } \\
\text { Per Year }\end{array}$ & 16 & 3 & $"$ & 1 \\
\hline
\end{tabular}


Table 2.8 $1 \mathrm{MW}$ Peat Fired Steam Generator Facility Requirements (page 2 of 2).

HARVEST METHOD
First Year Discharge Small
(Acre Feet)
Additional Second Year
Discharge
(Acre Feet)

Additional Net Water

Yield

(Percent)

Field Pumpage

Requirements

Water Controls

Bog Constraints

+ must be drainable

- must create a pool
MILLED PEAT

Small

$45-50$

Not Required

Small Treatment Facility
Not

Required

Sma 11

Sma 11

35

Small Treat-

ment Facility
DIRECT

EXTRACTION
Small

Applicable

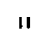

Sma 11

30

Not

Required

Small

Treatment

\section{OTHER REQUIREMENTS}

Annual Storage

Requirements (Days)

Daily Transportation

Trips to stockpiles

80 Yards $^{3}$ Trucks

7400 Yards $^{3}$ Trains
275

245

II

85

1
$N / A$

N/A

II

N/A 


\section{SECTION 3 - ENVIRONMENTAL ISSUES}

\subsection{INTRODUCTION}

Peatland development for energy production incorporates a complex series of processes that ultimately transform the stored caloric peat energy into SNG, liquid fuel, electricity, or steam for heating. As is true for any form of energy production, the use of peat for this purpose raises many environmental issues. These issues, the concerns they arouse, and the data required to resolve them are described in this section as they apply in any generic region or site. The initial concerns generally expressed in the ten states having major peat deposits are described in Section 4. Further analysis of these environmental issues is discussed in Appendix A.

\subsection{SCOPE AND CONTENT OF ISSUEES}

This study is focused on possible environmental issues raised by consideration of the use of peat as an energy source. However, it is important to note that a variety of other issues must also be resolved before a rational decision to proceed with peat development can be made. The range of development issues is shown in Figure $3-1$.

To a varying degree, each major environmental concern is affected by one or more of the other elements shown in this diagram. This can be illustrated by. constructing a relevance tree. This is a hierarchical structure in which the top levels contain the most aggregated and encompassing concerns. The lower levels describe the upper levels in successively greater detail and eventually provide the underlying information needed to satisfy the concerns.

An example of a relevance tree expressing the top level concerns for the use of peat is shown in Figure 3-2. Such an approach simplifies dealing with alternatives and understanding the relative role of a given factor. However, the compartmentalization is merely for conceptual simplification. In actuality, separations are not clearly defined. For example, use of a peat area for 


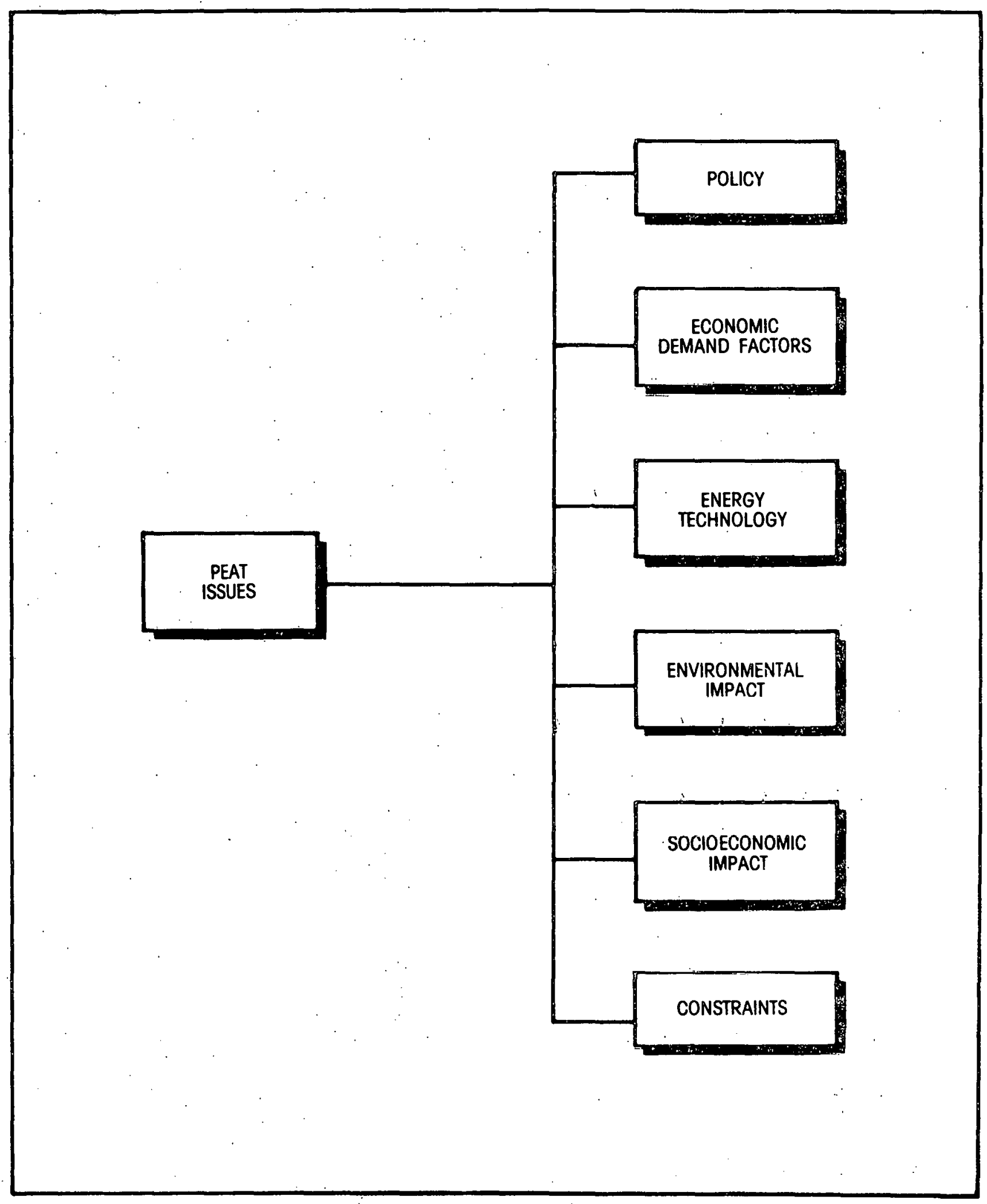

Figure 3-1 Range of Peat Development Issues 


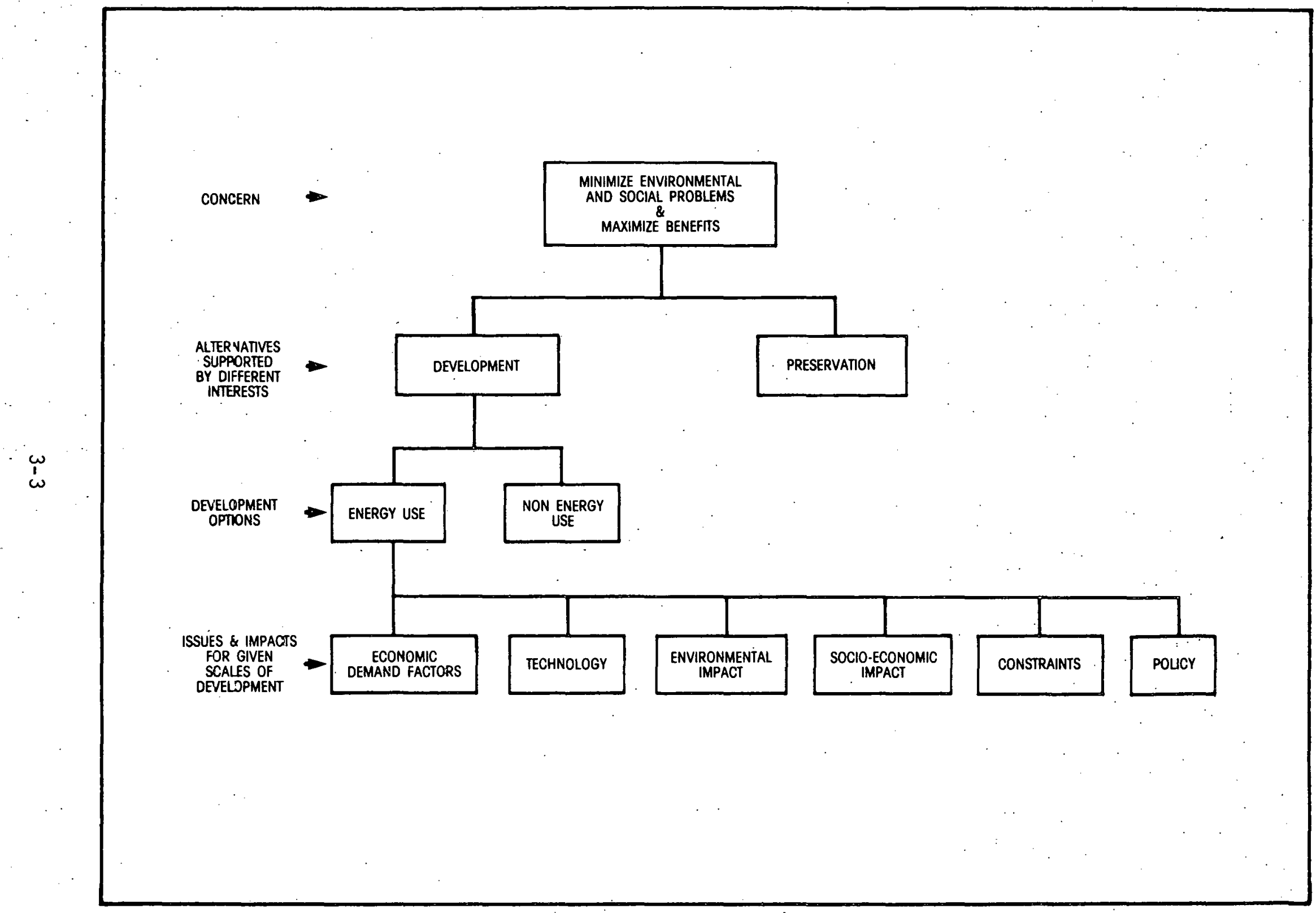

Figure 3-2 Relevance Tree for Defining Issues 
energy purposes does not preclude eventual non-energy use of the same area, after reclamation. In this case a low-value timber stand may be transformed into a higher value forest after the peat has been removed and drainage provided.

A complex set of relevancy trees was not formally developed for the myriad of issues, but each of the major issues and impacts that will affect the development of peat as an energy source are presented in Figures $3-3,3-4,3-5,3-6$, $3-7$, and 3-8.

Economic considerations and policy issues, although outside the scope of this study, are nevertheless extremely important in determining the level of environmental impact that can be considered acceptable. Socioeconomic issues are being considered in detail in a comparative study conducted for the DOE by Radian Corporation. The focus of this report is on the environmental impacts, concerns, and constraints illustrated in Figure 3-6.

\subsection{ISSUE IDENTIFICATION}

Any peat-related activity has been identified as an environmental issue for this report if it is the subject of present, or anticipated, environmental regulations or, as stated in 1.1, if concerned. individuals or agencies do not ayree whether it could produce adverse environmental impacts.

So that the study might have as broad as base as the available time would permit, appropriate Federal, state, and local resource prulection agencies, and development agencies, public interest groups, ànd industr1al represenlalives were asked to state their concerns about peat development, both in general and in specific respects. Particular emphasis was placed on discussions with individuals who have a professional or regulatory interest in peatlands, energy, geology, resource production, environmental protection, resource evaluation, fish and wildilife protection, and wetlands preservation. A list of those with whom discussions were held is presented in Appendix C. Environmental concerns were developed in more detail by conducting a review of relevant publications, 
Figure 3-3 Issues - Policy

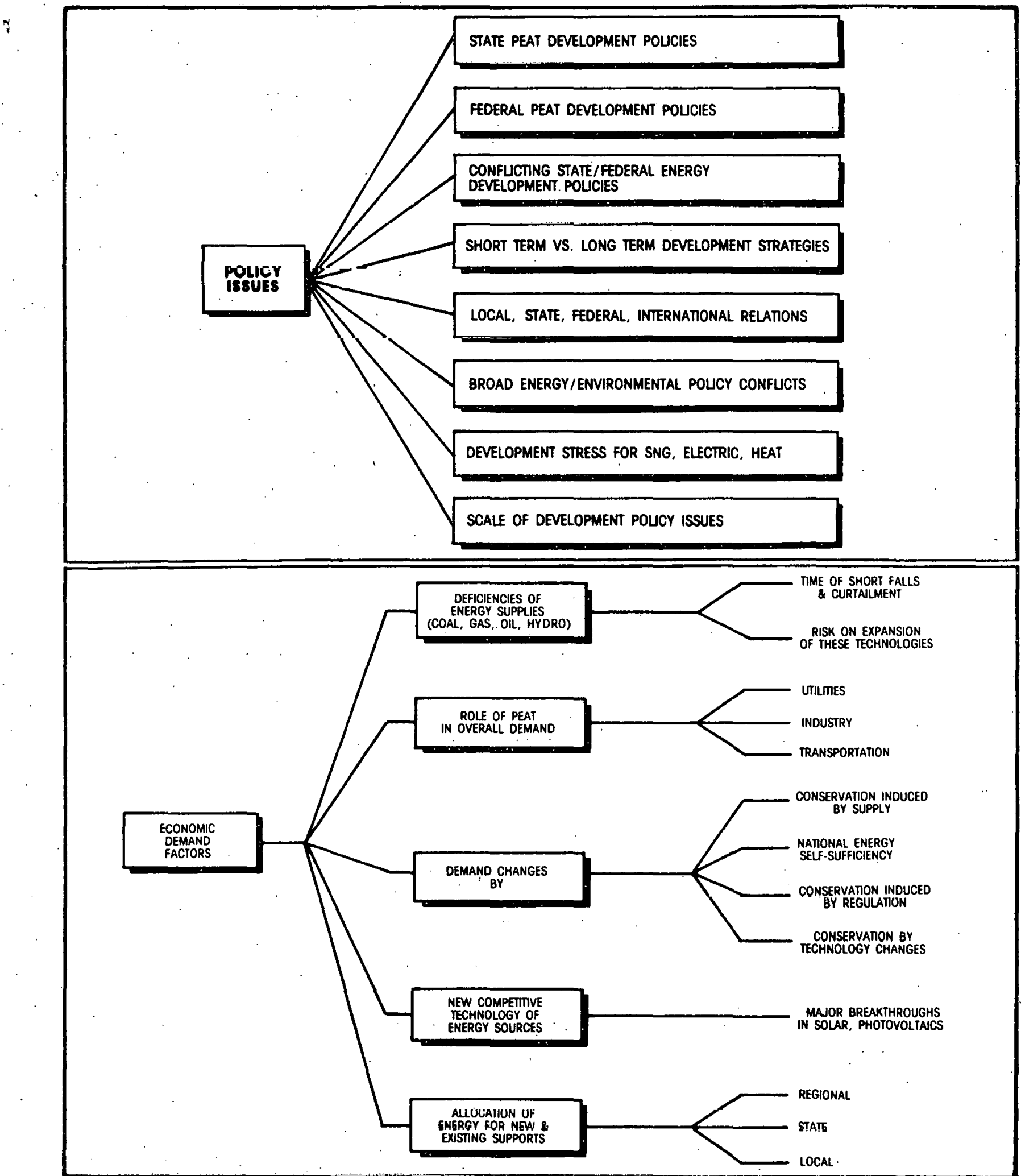

Figure 3-4 Issues - Economic Demand Factors 


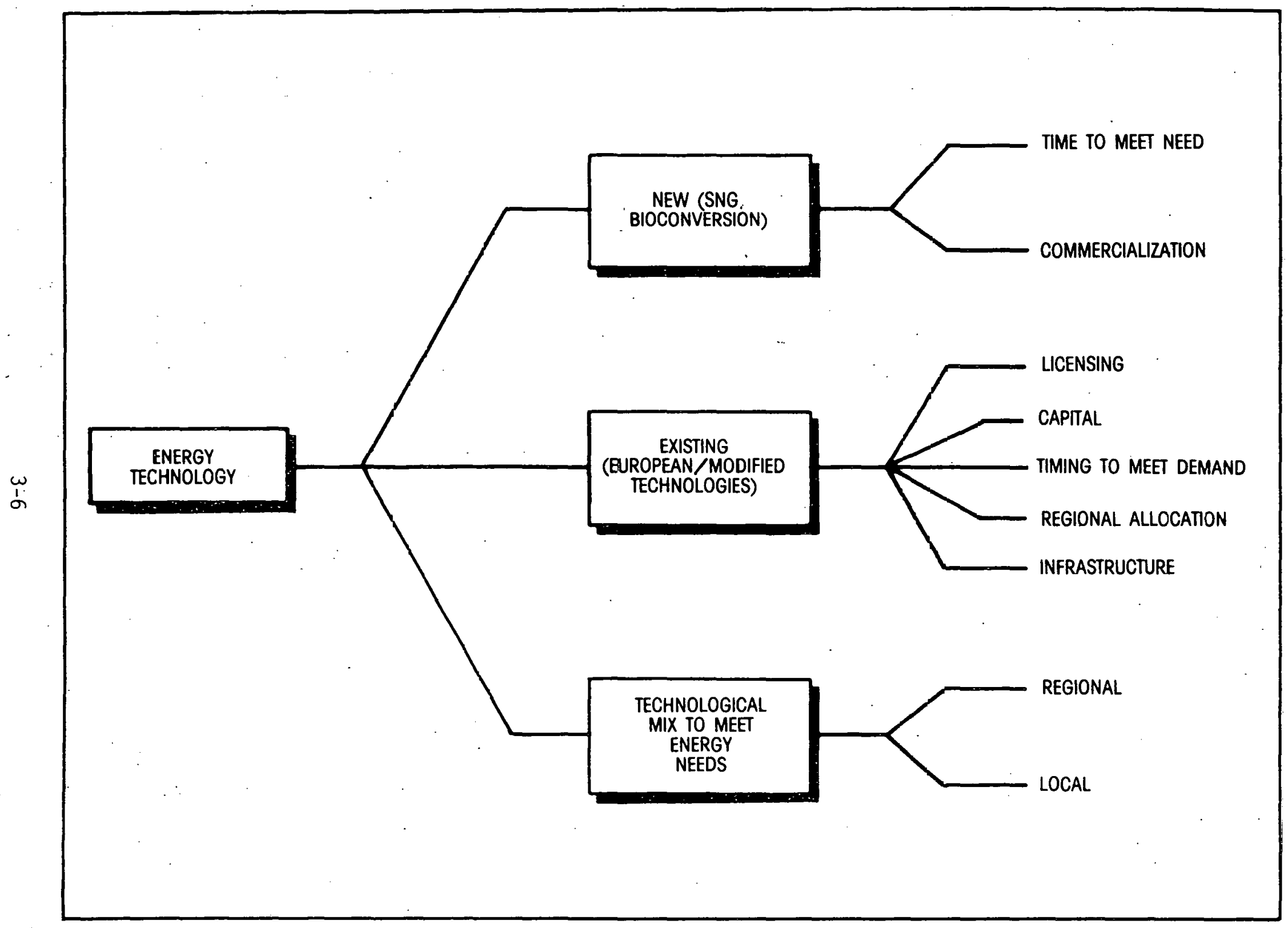

Figure 3-5 Issues - Energy Technclogy 


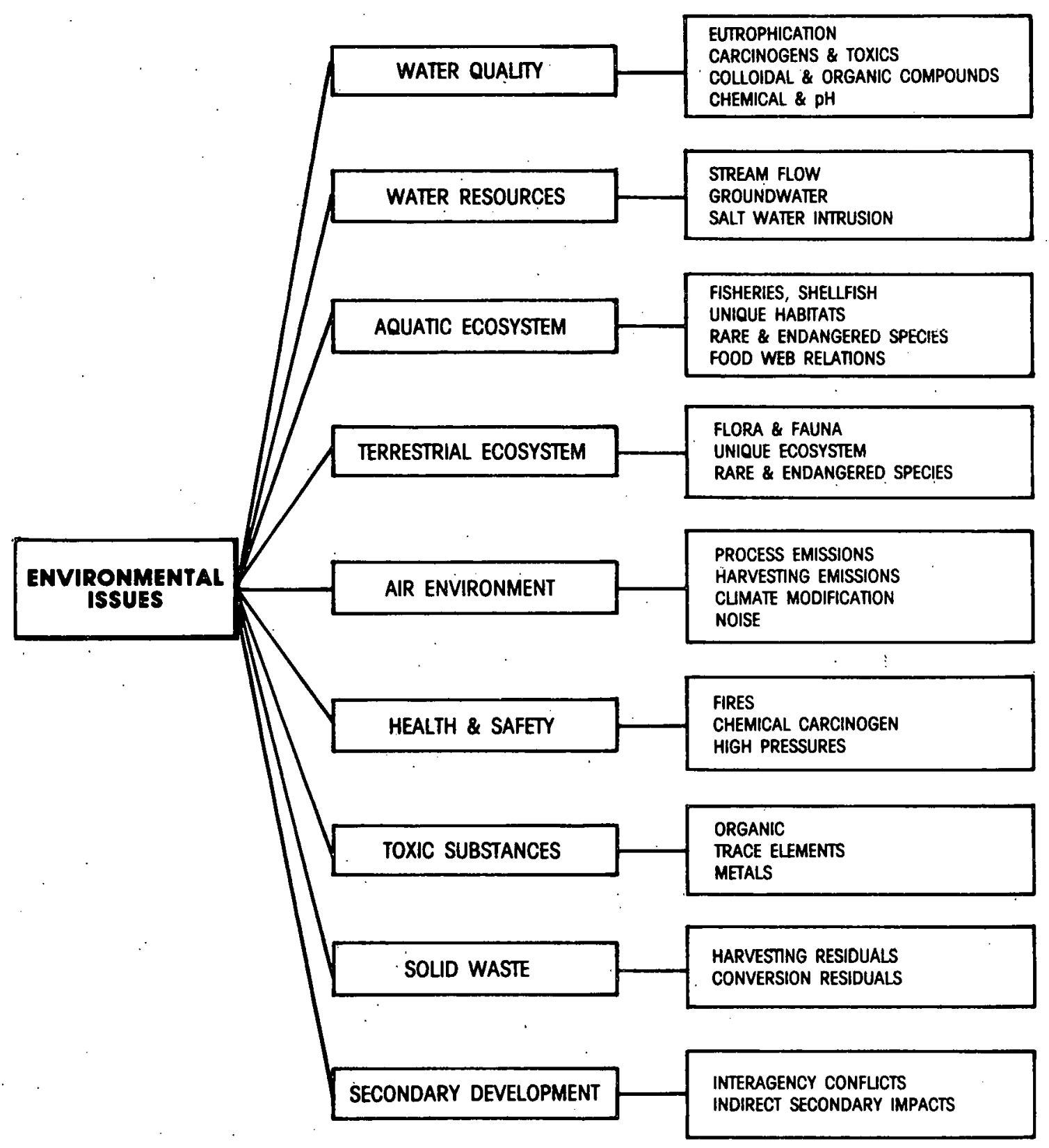

Figure 3-6 Issues - Environmental 


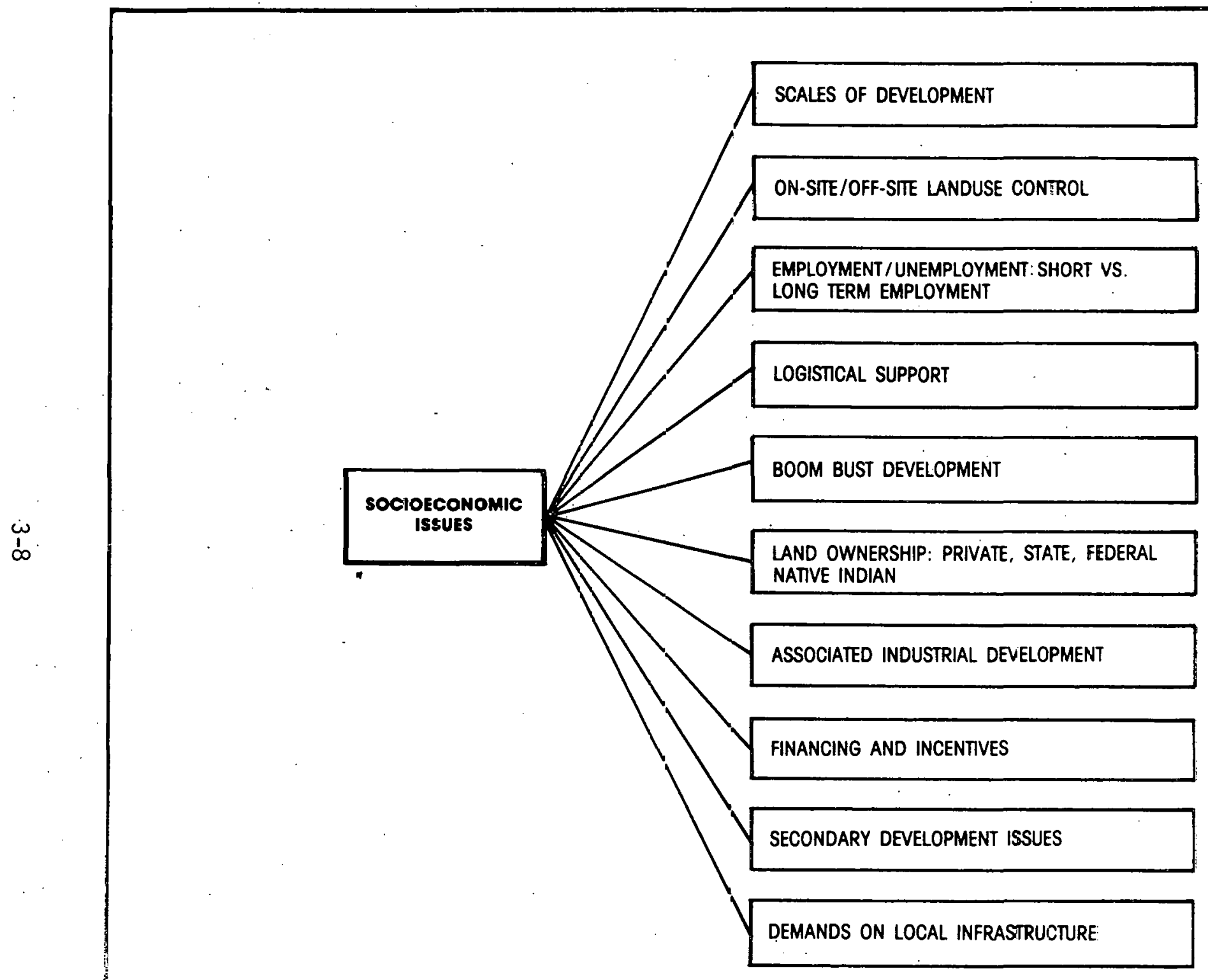

Figure $3-7$ Issues - Socioeconomic 


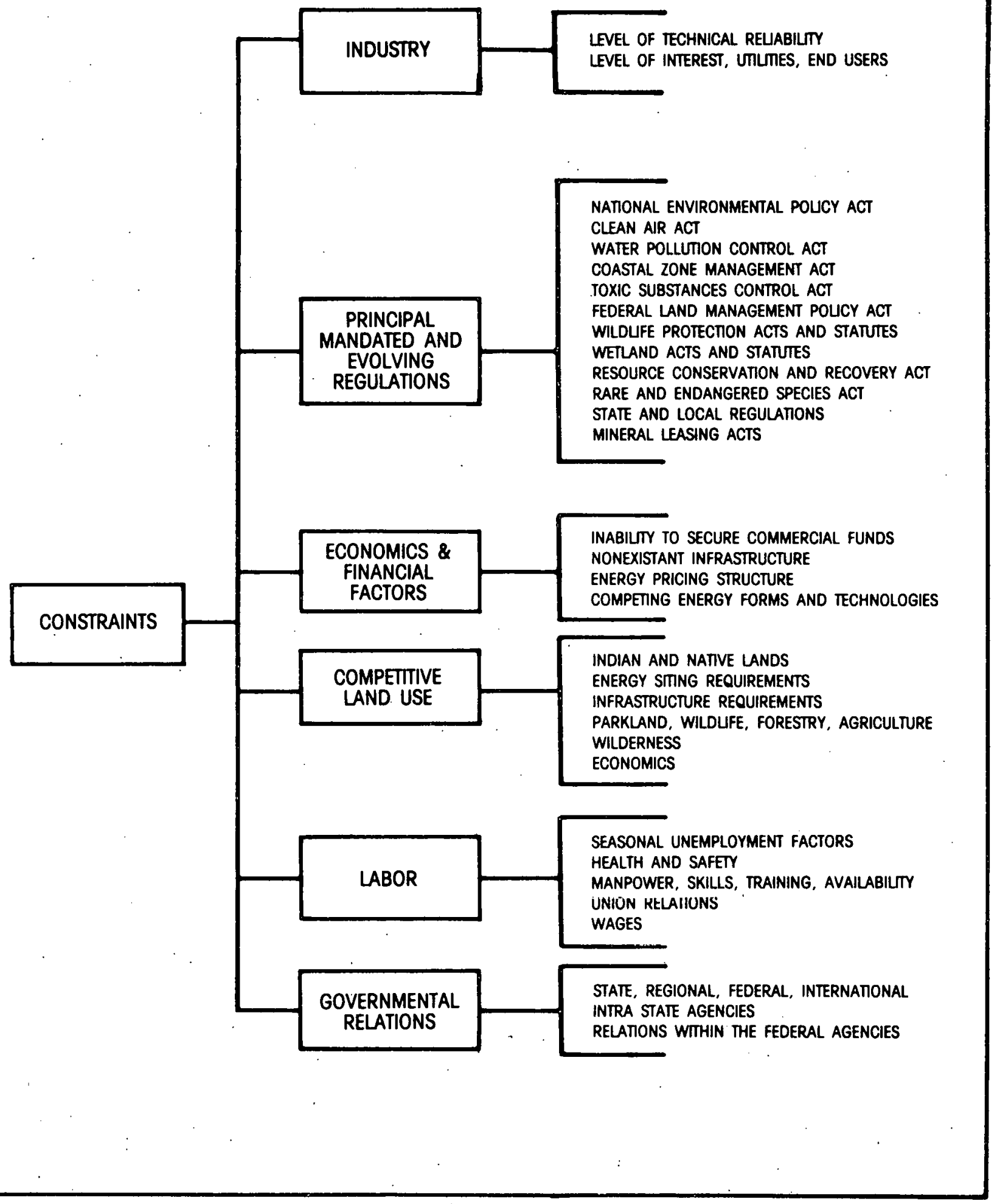

Figure 3-8 Issues - Constraints 
conference reports, and articles, and by analysing potential peat development scenarios to determine potential impact areas.

Figure 3-9 illustrates the spectrum of considerations that would affect the analysis of any site to determine whether and how to proceed with development of a peat energy program. If it is assumed that the proposed program is technically and economically feasible, it can be seen from the figure that all decisions to proceed rest on the satisfactory resolution of environmental issues.

These environmental issues are discussed in the folluwing subsections. These subsections are divided into broad environmental categories entitled Water Resources, Water Quality, Air Quality, Aqualic Ecosystem, Terrestrial Ecosystcm, Health and Safety, Regulations, Solid Waste, and Secondary Development Issues. Each general topic begins with a discussion of why environmental issues can be expected to arise in that particular category. In following subsections, the. specific potential environmental issues are identified and briefly described. A much more complete discussion of these environmental issues is given in Appendix A, within which the following data are provided for each issue:

- Issue

States the issue.

- Description

Provides a brief explanation of why the issue develops from the analysis.

- Leqislative/Institutional loncèns

Describes state and Federal interests in the issue and identifies regulations if applicable. 


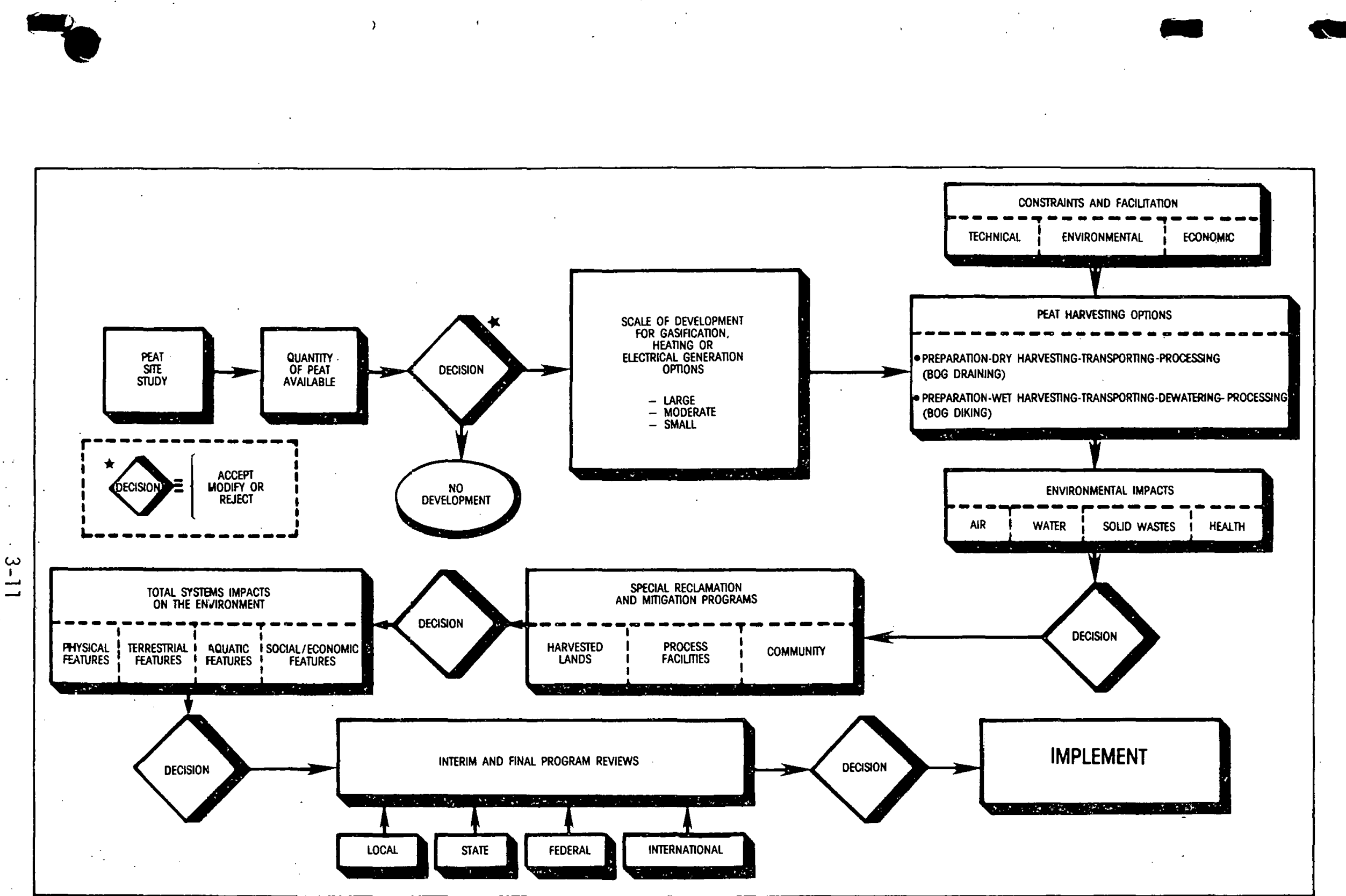

Figure 3-9 Site Development Analysis 
- Environmental Interests

Presents information on the general public interest in this issue and highlights any strong policies or attitudes suggested by contacted individuals.

- Environmental Goal

Gives a brief explanation of what can be defined as an acceptable resolution to the issue.

- Action/Dat.a Requi rement.s

Provides definition of the type of data that will be needed to answer questions raised by the issue. The subsection will be amplified where appropriate in the next phase of this study and integrated with section 5 (Uniform Data Collection Requirements).

It must be recognized that each particular environmental issue will require further definition as the peat research and development program advances and specific sites and technologies are reviewed. 


\subsection{WATER RESOURCE ISSUES}

The groundwater and surface water resources of a peatland provide environmental control for peatland development and support. The peatland's existence is controlled by the hydrological regime of the site and, in turn, the peat mass influences the surface and groundwater flows from the site. The development necessary for peat harvesting will modify the natural groundwater and surface hydrological characteristics of the area. These net onsite and offsite changes will largely be a function of the scale of development, harvesting procedures, and energy processing technologies. The net water resource impacts of several hundred or thousand acre developments should not cause major concerns when viewed from the larger basin perspective; however, the water resource changes produced by a development of tens of thousands of acres in one location could greatly modify the natural water resources. Water resource issues are a subset of the national wetlands issues, which also include issues of terrestrial and aquatic habitats and water quality. Listed below, in decreasing order of importance to the public, are specific water resource factors that, if modified by peat development, may become environmental issues.

1. Floodwater Runoff Response

2. Groundwater Elevations

3. Salt Water Intrusion

4. Surface Flow Patterns

5. Minimum Stream Discharges

6. Meàn Surface Water Dischärges

7. Hydrological Budget

8. Groundwater Aquifers

9. Evapotranspiration Rate

The effect of the scale of development upon the expected severity of these issues is indicated in Table 3.1. It can be seen that only increased floodwater runoff is expected to be a major issue, and then only for large-scale developments. The magnitude of these issues will be clearly defined only after generic computer models are established and applied to the general and specific field conditions. 
Table 3.1 Water Resource Environmental Issues

\begin{tabular}{|c|c|c|c|c|c|c|c|c|c|}
\hline \multirow{3}{*}{ DEGREE OF CONCERN } & \multicolumn{9}{|c|}{ SCALES OF DEVELOPMENT } \\
\hline & \multicolumn{3}{|c|}{ SMALL } & \multicolumn{3}{|c|}{ MODERATE } & \multicolumn{3}{|c|}{ LARGE } \\
\hline & Mavor & MODERATE & minor & MANOR & MODERATE & MINOR & MANOR & MODERATE & MINOR \\
\hline \multicolumn{10}{|l|}{$\begin{array}{l}\text { INCREASED FLOODWATER } \\
\text { FLOW POTENTIAL }\end{array}$} \\
\hline \multicolumn{10}{|l|}{$\begin{array}{l}\text { GROUNDWATER ELEVATIONS } \\
\text { MODIFICATION }\end{array}$} \\
\hline \multicolumn{10}{|l|}{$\begin{array}{l}\text { POTENTIAL SALT WATER } \\
\text { INTRUSION }\end{array}$} \\
\hline \multicolumn{10}{|l|}{$\begin{array}{l}\text { MODIFICATION OF SURFACE } \\
\text { WATER FLOW PATTERNS }\end{array}$} \\
\hline \multicolumn{10}{|l|}{$\begin{array}{l}\text { INCREASE MINIMUM } \\
\text { STREAM UISLHAHLES }\end{array}$} \\
\hline \multicolumn{10}{|l|}{$\begin{array}{l}\text { INCAEEASEE MEAN SURFACE } \\
\text { WATER DISCHARGE }\end{array}$} \\
\hline \multicolumn{10}{|l|}{$\begin{array}{l}\text { ALTER THE HYDROLOQICAL } \\
\text { BUDGET }\end{array}$} \\
\hline \multicolumn{10}{|l|}{$\begin{array}{l}\text { ALTER GROUNDWATER } \\
\text { AQUIFER }\end{array}$} \\
\hline $\begin{array}{l}\text { REDUCE EVAPO- } \\
\text { TAANSPIRATION }\end{array}$ & & & & & & & & & \\
\hline
\end{tabular}

During harvesting, water resource parameters will be modified for an intermediate period; the reclamation program selected will determine the permanent modification. These issues are more fully discussed below and in Appendix A.

\subsubsection{Water Resources: Increased Floodwater Runoff Résponse}

ISSUE

The development and the ultimate transformation of an upland peatland or a depressed peatbog into a reclaimed area could result in changes in the area's floodwater response.

\section{DESCR IPTION}

There is no general answer to the question of whether development and reclamation will lead to an increase or a decrease in runoff response. Certain factors could lead to an increase in the stormwater hydrological response: 
- Easier flooding routing as a result of the development of a drainage system,

- Decrease in interception losses,

- Potentialiy greater overland flows due to a reduction in infiltration and peat storage capacity, and

- Faster snow melt values due to the decrease of shading.

On the other hand; there are factors that would tend to decrease flood flows:

- Increased onsite storage capacity due to a net reduction in the water table,

- Greater infiltration created during reclamation by working the lower impermeable peat horizons into the underlying mineral soil, and

- The incorporation of flood flow controls in the drainage design program.

Because of these possible opposing factors, the net effects on the floodwater hydrograph of a specific development program will have to be determined by creating individual models for the various harvesting and reclamation schemes.

\subsubsection{Water Resources: Groundwater Elevation Modification}

ISSUE

The drainage and potential ponding of the harvested areas will cause changes in the surface and groundwater interflow to the adjacent watercourses.

\section{DESCRIPTION}

A peatland by its nature is a surface aquifier that has a water table at or near the ground surface. Groundwater levels during and after peat extraction 
are the paramount importance to the technical viability of the project. The ability to provide adequate control of the groundwater levels - either to float equipment for hydraulic harvesting or to drain the area for sod or milled harvesting - will be the prime determinant of the method of extraction. Changes in the groundwater balance may alter the area so that future uses are limited.

The groundwater characteristics of the area also determine subsurface flows and effects on stormwater flows, base flows, and deeper groundwater recharge. For these reasons, the groundwater characteristics of the peat level must be defined to determine the most appropriate harvesting techniques and control the impacts on the area's groundwater environment. Within coastal areas, saltwater intrusion can be attributed to reduced surface and groundwater flows.

\subsubsection{Water Resources: Potential Saltwater Intrusion Along Coastal Areas}

ISSUE

The drainage required to reduce the water levels of coastal peatlands could potentially lead to surface and groundwater saltwater intrusion.

DF SCRTPTION

Coastal peatland development at the North Carolina First Colony Farms has indicated that saltwater encroachment can pose a potential problem for development in coastal areas. (43) Peat harvesting within the coastal environment could induce iniand saltwater encroachment as the result of the construction of drainage canals, the reduction of groundwater recharge, and the lowering of the groundwater level. The ramification of the effects of this change shnuld he carefully analyzed prior to development. Such a transformation from a frechwater environment to a brackish estuarine environment would generate both positive and negative environmental effects. 


\subsubsection{Water Resources: Modification of Surface Water Flow Patterns.}

ISSUE

The construction of drainage ditches, roads, water control devices, and other land changes necessary for harvesting peat will modify the surface water flow regime of the harvested area and the downstream water channels.

\section{DESCRIPTION}

The use of upland fens, depressed bogs, and coastal peatlands will cause a rerouting of surface waters that may result in flooding, increasing channelization, or creating new channels into newly created watercourses. Surface flows may be entirely routed from one watershed into another. The rearrangement of the surface flows will require analysis to define the most practical methods of drainage and ponding control.

\subsubsection{Water Resources: Increased Minimum Stream Discharges}

ISSUE

Peatland development will increase the minimum stream discharges.

\section{DESCRIPTION}

The development of a peatland or peatbog for energy production will necessitate the drainage and short term elimination of the peatland's vegetal cover. The reduction in biomass will reduce the net evapotranspiration from the watershed and allow a greater portion of the net precipitation to drain. This condition will augment the area's low-flow discharge volumes. The ditching and drainage of a peatland or bog will also increase low-flow volumes by the reduction of the groundwater level within the peat, which will also reduce the net evapotranspiration potential, and by physically allowing more of the peatland to contribute its flow directly to the area's surface water courses. 
The increases of minimum streamflow volumes for the statistical 7, 15, 30, and 60 day low-flow volumes should benefit the area's water resources and aquatic communities.

\subsubsection{Water Resources: Increase Surface Mean Water Discharges}

ISSUE

During peat harvesting, increases in mean surface water discharges will occur from the sequential drainage of peatlands, release of process water, and further dewatering of the peat.

DESCRIPTION

Use of the milled, sod, or direct extraction peat harvesting methods necessitates the lowering of the peat water table to aid in initial peat dewatering and to permit movement of equipment. The immediate short term increase in surface water discharge from field drainage will amount to approximately 10 to 20 percent. Further reduction in moisture is necessary before final peat energy processing or storage. The process dewatering stage may produce an additional water volume equal to 10 to 30 percent of the net volume of peat harvested.

Similar volumes of water could eventually be discharged from the hydraulic harvesting system; however, this volume would depend greatly on the method of reclamation of the pond areas and the degree of water recycling. 


\subsubsection{Water Resources: Alter The Hydrological Budget}

ISSUE

The hydrological regime (budget) from extracted areas will be permanently changed by the peatland development and reclamation project.

DESCRIPTION

The transformation of a natural peatland area by peat removal into a reclaimed area will change the natural hydrological aspects of the site. In some respects, changes may be beneficial or detrimental offsite. The modeling of the hydrological parameters will be of paramount concern for technical aspects of peat harvesting and for determining the offsite environmental effects of the project. One of the major technical problems of peat utilization is the transformation of saturated peat into an optimum dry feedstock. The onsite hydrological aspects will govern the design of the dewatering process.

\subsubsection{Water Resources: Alter Groundwater Aquifers}

ISSUE

Peatland groundwater flows to consolidated and unconsolidated aquifers will be altered. In addition to the dynamic groundwater conditions within the upper peat horizun, ds discussed in 3.4.2 and 3.4.7, the groundwater contribution to the deeper consolidated and unconsolidated aquifer in the immediate area could be impacted.

\section{DESCRIPTION}

When a peatland is a signiflcant contributer to larger regional consolidated and unconsolidated aquifers, the effects of any positive or negative changes in the peatland's contribution should be investigated. This factor becomes especially important if the aquifer or groundwater supplies a significant 
amount of the region's water, as is the case in Florida. Extraction will change the upper peat horizon's hydrological regimes and the amounts of groundwater contributed to the upper unconsolidated and deeper consolidated aquifers.

\subsubsection{Water Resources: Reduce the Evapotranspiration Rate}

ISSUE

Lowering of the water surface and removal of the original flora characteristics of the peatland will change the net evapotranspiration of the developed area and cause unknown changes in adjacent plant and animal communities and in local climate.

\section{DESCRIPTION}

The formation of a peatland results from groundwater at or near the surface. Under these conditions, the natural vegetation community will evapotranspire at its full potential during the growing season. As discussed in 3.4.5, the artificial lowering of groundwater will create a moisture deficiency in the upper horizons that will result in the reduction of the net evapotranspiration rate. Net evapotranspiration reductions will also occur as the result of vegetal removal during the harvesting period. The duration of the reduced evapotranspiration will vary, depending on the harvesting technique employed and the sequencing of the reclamation program. Changes in the amount of evapotranspiration will also result from the specific reclamation schemes selected. 


\subsection{WATER QUALITY ISSUES}

The quality of surface waters being discharged from a peatland have characteristic quality parameters that to some degree control the onsite and downstream aquatic habitats and water uses. Peatland development will necessitate the eventual discharge of water and wastewater from the peat harvesting and energy processing activities. These discharges will contain increased concentrations of natural constituents and may contain unnatural chemicals derived from the peat dewatering and the energy process wastewater streams. These constituents can affect the onsite and downstream aquatic and estuarine ecosystems and potentially downstream domestic water users. Without controls on indiscriminate discharges, large organic and inorganic stream loadings may potentially result from a peat energy operation. The release of these organic and inorganic compounds can generate a variety of water quality impacts. In a general relative decreasing order of importance the foreseen water quality problems are from the discharge of water having the following characteristics:

1. Low $\mathrm{pH}$

2. High $\mathrm{BOD} / \mathrm{COD}$

3. Nutrients

4. Organic Compounds

5. Colloidal and Settleable Solids

6. Heavy Metals

7. Carcinogenic and Toxic Materials

The effect of the scale of development upon the expected severity of these issues is indicated in Table 3.2. It can be seen that the first three are expected to be of major importance in even a small-scale development. The potential biological response from discharging water with these characteristics could cause species shifts and possibly a reluctance on the part of downstream domestic water users to use the water. 
Table 3.2 Water Quality Environmental Issues

\begin{tabular}{|c|c|c|c|c|c|c|c|c|c|}
\hline \multirow{3}{*}{$\begin{array}{c}\text { PRIMARY } \\
\text { ENVIRONMENTAL } \\
\text { RESOURCE ISSUE }\end{array}$} & \multicolumn{9}{|c|}{ SCALES OF DEVELOPMENT } \\
\hline & \multicolumn{3}{|c|}{ SMALL } & \multicolumn{3}{|c|}{ MODERATE } & \multicolumn{3}{|c|}{ LARGE } \\
\hline & MANOR & MOderate & MINOR & MAJOR & MODERATE & MJNOR & MANOR & MODERATE & MINOA \\
\hline $\begin{array}{l}\text { DISCHARGE LOW } \\
\text { PH WATER }\end{array}$ & & & & & & & & & \\
\hline $\begin{array}{l}\text { DISC.HARRE HIOH } \\
\text { BOD/COD }\end{array}$ & & & & & & & & & \\
\hline DISCHARGE NUTRIENTS & & & & & & & & & \\
\hline $\begin{array}{l}\text { DISCHARGE } \\
\text { COMPOUNDS }\end{array}$ & & & & & & & & & \\
\hline $\begin{array}{l}\text { DISCHARGE COLLOIDAL } \\
\text { SETTLEABLE SOLIDS }\end{array}$ & & & & & & & & & \\
\hline
\end{tabular}

These water quality issues are described below and more fully discussed in Appendix A.

\subsubsection{Water Quality: Low pH}

ISSUE

The drainage of peatlands and any process water will necessitate the discharye of low-pH water. This discharge may be within state discharge standards and yet still affect the area's aquatic resources.

\section{DESCRIPTION}

The acidic quality of a peatland water chemistry system is principally due to the initial lack of natural buffering capacity from the incoming waters and to hydrogen ion and organic acid production by the plants' photosynthesis and 
decomposition. The $\mathrm{pH}$ values for water coming from an ombotrophic (severly cation deficient) groundwater fen can range as low as 3 to 4 and from a minerotrophic (moderate cation deficient), from 4 to 8 . The release of additional volumes of low-pH drainage water can further stress an already poor quality surface water system. The depression of surface water $\mathrm{pH}$ value can generate significant changes in the aquatic ecosystems. These $\mathrm{pH}$ changes can be in the form of species specific fertility problems, morbidity, mortality, and mobility problems, and other physical and physiological problems. Overall, these factors may affect shift in species diversities and general habitat vigor.

\subsubsection{Water Quality: BOD/COD}

\section{ISSUE}

The discharge of peat drainage water and process water from the dewatering and SNG facility will contain higher than normal values of organic materials producing 5-day Bio-chemical 0xygen Demand (BOD) and Chemical 0xygen Demand (COD).

\section{DESCRIPTION}

The discharge of oxidizable sugars, amino acids, fats, alcohols, waxes, carbohydrates, cellulose, and hemicellulose, all integral constituents of peat, would cause an oxygen deficiency as measured by the standard water quality COD and BOD methods. The release of soluble and insoluble materials that would depress the oxygen levels of the receiving stream must be controlled to meet the state and National Pollutant Discharge Standards and to maintain stipulated stream oxygen standards. Depression of the oxygen levels could occur from increased turbidity within the stream and the natural aerobic microbial decomposition of soluble and insoluble constituents. 


\section{3:5.3 Water Quality: Nutrients}

ISSUE

The drainage of peatlands and peat dewatering can create the discharge of nitrogen and phosphorus compounds that may increase eutrophication rates.

\section{DESCRIPTION}

The approximate ranges of nitrogen and phosphorus concentration percentages in dried peat are 0.3-4.0 and 0.01-0.5, respectively. Both of these compuund groups are supplied to the peatlands from precipitation and groundwater sources. In addition, nutrient concentration can be accumulated by bacterial fixation. Peat has been shown to store nitrogen and phosphorus and has been considered for use as a filter in wastewater treatment processes. Consequently, during drainage and processing, high loadings of these nutrients could be released to the receiving water system.

The net. effect of the increased nutrient would be an increase in eutrophication rates and associated changes in the aquatic ecosystem.

\subsubsection{Water Quality: Chemical Compounds}

\section{ISSUE.}

Organic compounds make up 20 to 98 percent of the lutal dry weight of pcat. $\Lambda$ portion of the organic makeup of peat is derived from organic dcids. Toxicity studies conducted on fish raised in peatland drainage waters indicated that the toxicological constituents present in the water would repel the fish and even cause death at sufficiently high concentrations.

Selected peatlands are known. natural repositories of heavy metal ions. The mobilization of these ions could occur as a result of draining the peat complex, dewatering the peat before processing, leaching the metals from ash disposal, or settling of air pollutants. 
With the increased public concern as to possible carcinogen emissions from a new industry, water effluent streams should also be tested for carcinogenic and toxic organic materials.

\section{DESCR IPTION}

Fatty acids, humic acids, amino acids, tannic acids, and other organic acids are integral constituents of peat. The presence of these chemicals helps depress the $\mathrm{pH}$ of the drainage and interstitial water and may have a direct toxicological effect on aquatic organisms. Peat drainage and dewatering processes will result in the release of these compounds to the aquatic environment.

Peat, as with any flora, also contains microlevels of heavy metal ions that are used for the life processes and are released and recycled upon ignition or decomposition. Heavy metals in a peatland are also derived directly from the filtering of surface waters and from pollutant fallout directly onto the peat surface. The peat system is more confined than most terrestrial systems, and the small mineral supply entering a fen or bog is incorporated into peat growth in the active aerobic zone or becomes tied up and accumulated in the buried decomposed material. With the draining, dewatering, and ultimate processing of the peat for energy production, these metals can again be released in the air, water, and solid waste streams. The uncontrolled release of these materials into the wastewater and drainage discharge may contravene existing state effluent standards and established stream quality criteria.

The harvesting and energy production of peat can possibly lead to the inadvertent release of phenols and complex organic compounds. The toxic and carcinogenic risks of these effluents can only be ascertained after their production mechanisms and environmental rates are defined. To determine this, all effluent streams should be qualitatively and quantatively analyzed to determine the characteristics of the organic chemicals, being released. If hazardous materials are found in the effluent streams, the fate of the hazardous materials in the aquatic ecosystem should be determined and potential impacts on downstream water supply systems should be defined. 


\subsubsection{Water Quality: Colloidal and Settleable Solids}

ISSUE

The harvesting and dewatering of large quantities of peat could potentially release large concentrations of colloidal and settleable solids into the receiving streams.

\section{DESCR IPTION}

Peat is composed of water-soluble colloidal material and small particles of indistinguishable cellulose and fibrous materials. The disturbance of the peal during ditching, drainage, harvesting, and process dewatering may release some of these materials into the receiving stream. Because of the nature of these materials and the adsorped constituents, the release of colloidal and particulate matter would be expected to depress the oxygen levels and increase transport of nutrients that may enhance eutrophication rates and heavy metals that are potentially toxic to aquatic organisms. Consequently, discharge standards for settleable solids are establised to prevent these impacts. 


\subsection{AIR QUALITY ISSUES}

The relative importance of the various air quality issues is indicated in Table 3.3. The issues are described below and discussed in more detail in Appendix A. As illustrated in this table the only major degree of air quality concern is from the fugitive emission factors from the large-scale peat harvesting and storage operations. These factors could be effectively controlled with wet harvesting or by careful dry harvesting techniques.

The small 1MW industrial boiler and the 60MW electric powerplant fired by peat, should be expected to produce less air quality impacts than their coal-fired counterparts. Peat, with its generally low sulfur and mineral content, would have comparably low emissions of $\mathrm{SO}_{x}$ and particulate air pollutants. Particulate emissions would be controlled through normal air pollution control technology. collected flyash has been demonstrated to be a safe soil conditioner and could be used for soil reclamation.

The air emissions from a peat SNG facility can be discussed only on a generalized basis. Studies conducted for the Institute of Gas Technology peat gasification program indicate that the emission rates from a large-scale peat SNG plant would be 3.5 ton/day airborne particulates, 1.7 ton/day sulphur oxides, 15.6 ton/day nitrogen oxides. $(46,47)$ All of these values are less than $1 / 3$ of those of a comparably sized coal-fired powerplant. Additional air emissions from sulfur recovery tailgas treatment, fired-heaters, and waste handling and disposal can include reduce sulfur dild nitrogen compounds, carbon monoxide, heavy metals will add hydrocarbons, and halogens.

Peat dry harvesting, transportation, and storage to the overall particulate emission problem. For example, the wind drift from a large-scale milled-peat operations could contribute to local and farfield air and water quality problems.

It can be expected that large-scale facilities and most moderate-scale facilities will be located in relatively undeveloped areas. Therefore, emission offsets (EO) will probably not be required and Prevention of Significant Deterioration 
Table 3.3 Air Quality Environmental Issues

\begin{tabular}{|c|c|c|c|c|c|c|c|c|c|}
\hline \multirow{3}{*}{ DEGREE OF CONCERN } & \multicolumn{9}{|c|}{ SCALES OF DEVELOPMENT } \\
\hline & \multicolumn{3}{|c|}{ SMALL } & \multicolumn{3}{|c|}{ MODEERATE } & \multicolumn{3}{|c|}{ LARGE } \\
\hline & MANOR & MODERATE & MinOR & MNJOR & MOOERATE & MINOR & MAJOR & MOMFRATE & MINOA \\
\hline $\begin{array}{l}\text { HARVESTING EMISSION } \\
\text { FUGITIVE DUST }\end{array}$ & & & & & & & & & \\
\hline $\begin{array}{l}\text { CARBON MONOXIDE } \\
\text { EMISSIONS }\end{array}$ & & & & & & & & & \\
\hline $\begin{array}{l}\text { NITROGEN OXIDE } \\
\text { EMISSIONS }\end{array}$ & & & & & & & & & \\
\hline $\begin{array}{l}\text { SULFUR OXIDE } \\
\text { EMISSIONS }\end{array}$ & & & & & & & & & \\
\hline $\begin{array}{l}\text { PARTICULATE } \\
\text { EMISSIONS }\end{array}$ & & & & & & & & & \\
\hline $\begin{array}{l}\text { NONMETHANE HYORO- } \\
\text { CARBON EMISSIONS }\end{array}$ & & & & & & & & & \\
\hline $\begin{array}{l}\text { PHOTO CHEMICAL } \\
\text { OXIDANTS }\end{array}$ & & & & & & & & & \\
\hline $\begin{array}{l}\text { HEAVY METAL } \\
\text { EMISSIONS }\end{array}$ & & & & & & & & & \\
\hline $\begin{array}{l}\text { REDUCED SULFUH } \\
\text { COMPOUND EMISSIONS }\end{array}$ & & & & & & & & & \\
\hline $\begin{array}{l}\text { NITROGEN COMPOUND } \\
\text { EMISSIONS }\end{array}$ & & & & & & & & & \\
\hline $\begin{array}{l}\text { HALOOEN COMPOUND } \\
\text { EMISSIONS }\end{array}$ & & & & & & & & & \\
\hline $\begin{array}{l}\text { VISIBILITY } \\
\text { REDUCTION }\end{array}$ & & & & & & & & & \\
\hline $\begin{array}{c}\text { WATER VAPOR } \\
\text { EMISSIONS }\end{array}$ & & & & & & & & & \\
\hline $\begin{array}{l}\text { CARBON DIOXIDE } \\
\text { EMISSIIINS }\end{array}$ & & & & & & & & & \\
\hline
\end{tabular}

$\infty$ 
(PSD) regulations can be expected to apply. Undeveloped areas, particularly near Native American lands, may have PSD Class 1 areas nearby, which can result in stricter emission limitations.

\subsubsection{Air Quality: Fugitive Dust}

ISSUE

Fugitive dust emissions from open field peat harvesting, especially by the milled-peat or sod-peat methods, could cause a local nuisance and contribute to ambient Total Suspended Particulate (TSP) levels.

Fugitive dust emissions from the stockpiling, storage, and transportation could also cause a local nuisance and might contribute to ambient TSP levels.

\section{DESCRIPTION}

Peat extraction by the milled-peat or sod-peat processes requires dry peat to be left on the ground surface. The drying peat can be suspended by wind and by mechanical action.

The multiple steps required to collect, store, transport, and re-store peat allow for many avenues of spillage and loss to the atmosphere, especially in open, wind-prone areas.

\subsubsection{Air Quality: Carbon Monoxide}

ISSUE

larbon monoxide (CO) emissions from dirert rombustion of sod peat, peat briquettes, or peat-fuel may exceed allowable levels. Carbon monoxide emissions from fired-heaters in a peat synfuel plant may also be significant. 
DESCRIPTION

Incomplete combustion of peat will lead to the emission of carbon monoxide from combustion processes; carbon monoxide is not easily collected in scrubbers and, in general, is controlled only by improving the combustion process. Solid fuels, such as peat, are prone to carbon monoxide emissions because of the chemical concentration gradients inherent in solid fuel combustion. Carbon monoxide emissions from peat synfuel plants may also be significant, but they are more readily controlled.

\subsubsection{Air Quality: Nitrogen Oxides}

\section{ISSUE}

Nitrogen oxides emissions from direct combustion of peat fuel may exceed allowable levels. Emissions from the fired-heaters in a peat synfuels plant may be significant and difficult to control.

\section{DESCRIPTION}

Nitrogen oxides $\left(\mathrm{NO}_{\mathrm{X}}\right)$, particularly nitric oxide (NO), are formed whenever fuels are burned in air. Emissionns tend to increase with incrcusing temieralure, heterogeneity of combustion composition, and fuel nitrogen. Although peat has relatively high fuel nitrogen concentrations that could result in increased $\mathrm{NO}_{\mathrm{X}}$ formation during combustion, would be offset by the low peat combustion temperatures. Nitric oxide is oxidized to nitrogen dioxide $\left(\mathrm{NO}_{2}\right)$ in the atmosphere. Nitrogen diuxide catalyzes the formation of photochemical air pollutants. Additional $\mathrm{NO}_{\mathrm{X}}$ can be generated at synfuels plants if waste ammonia is disposed by combustion. 


\subsubsection{Air Quality: Sulfur Oxides}

ISSUE

Sulfur oxide $\left(\mathrm{SO}_{\mathrm{x}}\right)$ emissions from direct combustion of peat fuels may exceed allowable levels. Emissions from fuel burning equipment at peat synfuels plants may also be significant. These emissions might aggravate the acid rains problems experienced in the northern and eastern U.S.

DESCR IPTION

Peat contains small concentrations of sulfur that are released as $\mathrm{SO}_{2}$ (or $\mathrm{SO}_{3}$, or acids) during combustion. Rapid droplet formation occurs in the plume because of the strong affinity of $\mathrm{SO}_{2}$ and $\mathrm{SO}_{3}$ for water. Subsequent oxidation of the $\mathrm{SO}_{2}$ in the plume, mostly in the condensed phase, increases this affinity and the activity of the droplets. Long-distance transport of these emission products can result in acid rains in remote areas, causing damage to soils, vegetation, and the aquatic ecosystem. However, peat is relatively low in sulfur content and may. not cause severe So emission problems when it is burned.

\subsubsection{Air Quality: Particulate Emissions}

ISSUE

Particulate emissionis frum direct combustion of peat-fuel may exceed allowable levels. Particulate emissions from peat synfuels plants may also be significant, but would be easier to control.

\section{DESCRIPTION}

Direct burning of sod peat, peat briquettes, or peat-fuel can generate particulate matter, including particulate sulfate, heavy metals, polynuclear aromatic hydrocarbons (PAH), and some particles in the submicron range. Qualitative standards for TSP may evolve because of varying environmental impact, depending 
on the chemical composition of particulate matter. Particulates from natural sources contribute the major portion of TSP in many areas of the U.S., especially the west.

\subsubsection{Air Quality: Non-Methane Hydrocarbon}

ISSUE

Non-methane hydrocarbon (NMHC) emissions from direct combustion of sod peat, peat briquettes, or peat-fuel may exceed allowable levels. Emissions from peat synfuels plants, especially storage vësels, may also be significant. Polynuclear aromatic hydrocarbons (PAH) are often carcinogenic and present special problems.

\section{DESCRIPTION}

Incomplete combustion of peat can lead to the emission of non-methane hydrocarbons that can react in the atmosphere to produce photochemical oxidants.

Most control strategies for the control of ambient ozone involve emission controls on NMHCS. PAHs are very stable in the envirumenl and can be careinogenic at very low levels.

\subsubsection{Air Quality: Photochemical 0xidants}

ISSUE

Photochemical oxidants derived from emissions from direct combustion of sod peat, peat briquettes, or from peat-fuel ur peat synfuels plants may viulate NAAQS. 
Photochemical oxidants (ozone) are formed in the atmosphere from non-methane hydrocarbons and nitrogen dioxide. They are controlled by emission controls on sources of .NMHC and, possibly, of oxides of nitrogen. Evaporation losses from hydrocarbon storage vessels and emissions from internal combustion engines are the major sources of NMHCs.

\subsubsection{Air Quality: Metals}

ISSUE

Metal emissions from direct combustion of sod peat, peat briquettes, or peat fuel or from peat synfuels plants may exceed allowable levels.

\section{DESCRIPTION}

Metals concentrated in the inorganic or organic portions of peat can be emitted as suspended particles or volatilized at high combustion temperatures and emitted as gaseous molecules. These metals behave in complex fashion in the ambient air and have complex effects. Metals have accumulated in the peat from filtering of water as it has flowed through the bog and by deposition from the atmosphere. Metal emissions from synfuels plants can result from operations other than fuel combustion, such as thermal oxidation for waste disposal. 


\subsubsection{Air Quality: Reduced Sulfur Compounds}

ISSUE

Reduced sulfur emissions from peat synfuels plants may exceed allowable levels.

DESCRIPTION

Reduced sulfur compounds in small quantities will be emitted from the acid gas removal/sulfur recovery systems. Meteorological conditions and ambient air chemistry will determine the impact on air quality.

3.6.10 Air Quality: Nitrogen Compounds (Other than $\mathrm{NO}_{\mathrm{x}}$ )

ISSUE

Nitrogen compounds from peat synfuels plants may exceed allowable levels.

DESCRIPTION

Ammonia and hydrogen cyanide which may be emitted from sour water treatment systems contribute to air pollution in complex ways, depending on meteorological conditions and ambient air chemistry.

\subsubsection{Air Quality: Halogen Compounds}

\section{ISSUE}

Halogen compounds from peat synfuels plants may exceed allowable levels.

DESCR IPTION

Hydrogen chloride and hydrochloric acid may be emitted from peat synfuels plants; especially if thermal oxidation is used in wastewater treatment systems. 


\subsubsection{Air Quality: Visibility}

ISSUE

Visibility reduction due to emissions from direct combustion of sod peat, peat briquettes, or peat-fuel may exceed allowable increments. Peat synfuels plants may also cause significant visibility reduction.

\section{DESCRIPTION}

Visibility reduction in the immediate vicinity of the combustion source can result from the emission of particulate matter and from plume condensation (water vapor). The severity of the effect will depend greatly on the rate at which the matter is dispersed by the winds. Visibility reduction on a large scale occurs through the formation of photochemical aerosols from directly emitted precursors, such as $\mathrm{NMHC}$ and $\mathrm{NO}_{\mathrm{x}}$. This issue is especially significant if nearby Class I areas are affected.

\subsubsection{Air Quality: Water Vapor}

ISSUE

Water vapor emissions from facilities employing direct combustion of sod peat, peat briquettes, or peat-fuel or from synfuel plants may create a local nuisance and create hazards to navigation and to the puhlir. hy reducing visibility and promoting increased chemical activity of other pollutants, such as the formation of acid mists when combined with $\mathrm{SO}_{\mathrm{x}}$.

\section{DESCRIPTION}

Water vapor emissions from combustion sources can condense and precipitate immediately downwind from the combustion source under certain meteorological conditions. This can lead to enhanced local rainfalls or snowfall with potential adverse impacts. Icefog can occur at the extremely low temperatures experienced during winter in northern peatlands, such as Minnesota and Alaska. 


\subsubsection{Air Quality: Carbon Dioxide}

ISSUE

The production of peat energy will necessitate the emission of carbon dioxide. Peat conversion to other forms of energy would contribute to the build-up of carbon dioxide.

\section{DESCRIPTION}

Burning of fossil fuels releases $\mathrm{CO}_{2}$ into the earth's atmosphere. Production and consumption of synfuels such as peat produces more $\mathrm{CO}$ ? per useful Btu than does direct burning. Within the scientific community, there is a current debate as to the significance of the global carbon dioxide concentrations on the earth's climatology. This concern may influence future emission standards and energy production policies. 


\subsection{AQUATIC ECOSYSTEM ISSUES}

The aquatic environmental issues that arise as the result of peatland development are inexorably linked with the water quality and terrestrial ecosystem environmental issues. For the purposes of this discussion, the aquatic environment is defined as the true open water bodies and not the wet areas or semiemergent areas, which are discussed in the terrestrial environment section. The areas that would be analyzed for a freshwater resource would also be similarly defined if the peatland were part of an estuarine system. The primary aquatic ecosystem environmental issue is to protect the fishery resource and all of the environmental parameters, foodwebs, water quality, and physical habitat that are necessary for their existence. The relative importance of these issues in relation to the three scales of development is shown in Table 3.4.

Table 3.4 Aquatic Ecosystems Environmental Issues

\begin{tabular}{|c|c|c|c|c|c|c|c|c|c|}
\hline \multirow{3}{*}{$\begin{array}{c}\text { PRIMARY } \\
\text { ENVIRONMENTAL } \\
\text { RESOURCE ISSUE }\end{array}$} & \multicolumn{9}{|c|}{ SCALES OF DEVELOPMENT } \\
\hline & \multicolumn{3}{|c|}{ SMALL } & \multicolumn{3}{|c|}{ MODERATE } & \multicolumn{3}{|c|}{ LARGE } \\
\hline & MAJOR & MODERATE & MINOR & MAJOA & MODÉaAte & MINOR & MANOR & MODEAATE & MINOR \\
\hline FISHERY INTERACTIONS & & & & & & & & & \\
\hline PHYSICAL INTEAACTIONS & & & & & & & & & \\
\hline FOOOWEB INTERACTION: & & & & & & & & & \\
\hline $\begin{array}{l}\text { UNIQUE AND RARE } \\
\text { AQUATIS MARITATS }\end{array}$ & & & & & & & & & \\
\hline
\end{tabular}

As previously discussed in the water quality and water resource environmental issues, impacts will be generated on physical and chemical components of the aquatic habitat and consequently will affect the biological residents. The aquatic environmental issues are a major portion of the entire wetlands issue 
of peatlands development. Preliminary studies conducted for peat energy development in Minnesota and North. Carolina have indicated detrimental consequences from changes in water quality. The maintenance of a stable, healthy fishery resource within the peatland harvesting area and all downstream areas is one of the most critical environmental concerns. The fishery maintenance environmental issue is ranked as the most significant aquatic ecosystem environmental concern because of the sensitivity of the fishery resources and the potentially large impacts on an area's water resources from moderate-and large-scale peat harvesting operations.

The resource sensitivity is reflected in the stringency of state and Federal laws protecting the fishery from direct and indirect impdcls.

The principal aquatic ecosystem issues and concerns are those dealing directly with the fishery interactions, foodweb interactions, physical interactions, and impacts on unique aquatic habitants. These issues are described below and discussed in more detail in Appendix $A$.

Peatlands such as bogs, fens, and pocosins create characteristic aquatic ecosystems within and downstream of the area. The drainage and/or ponding necessary for peat harvesting, in combination with the transition of the peatlands from a natural habitat to an unknown condition, will generate physical and chemical changes that will effect the aquatic and estuarine ecosystems. The development of the peatlands may not produce as significant an impact on an aquatic ecosystem as on the terrestrial ecosystem. However, because of the sensitivity of the aquatic and estuarine resources, more stringent offsite protection may be required. State and Federal regulations are providing stronger protection for the wetlands and the downstream aquatic and estuarine ecosystem. The following potential environmental issues in the aquatic ecosystem resulting from the initiation of a peat development program have been identified. 


\subsubsection{Aquatic Ecosystem: Fisheries}

ISSUE

Peatlands contain extensive headwater areas that support commercial, subsistence, and sport fisheries. The development of a large peat energy complex may affect these fishery resources.

\section{DESCRIPTION}

Peat resource development has a potential of either generating a severe impact or providing beneficial effects on the local fisheries. The determination of positive and negative effects of the program must be defined on a case-by-case basis, since the surface waters within a peatland complex may provide a nursery, migratory, or adult habitat for the indigenous species. In such a diverse habitat, net changes in the water resources may have differing impacts on separate aquatic species. Potential beneficial affects of the program would occur if, for example, low flows are supplemented with good quality water; increased habitat is created by the formation of additional drainages and lakes; or small increases in micronutrients are discharged from drained areas. The opposite situation could occur if water quality or other stresses are placed on the system that adversely impact the fishery resource. A few common examples of these conditions are discharge of poorer quality water, reduction of dissolved oxygen levels, removal of habitat, severe sedimentation, salinity changes, and temperature stresses.

Since the promotion and maintenance of the fishery is the prime aquatic resource management objective, any potential positive or negative affects of peat development would have to be fully analyzed. 


\subsubsection{Aquatic Ecosystem: Foodweb Interactions}

ISSUE

Integral portions of the aquatic foodweb are the molluscs, crustaceans, insects, worms, zooplanton, and phytoplankton. These species are necessary for the aquatic ecosystem to function. Consequently, impacts on this trophic level will be reflected in the more important fishery populations.

\section{DESCRIPTION}

Changes in the physical and chemical aquatic environment will be reflected in carnivore and herbivore populations in a. short period of time. These changes could be beneficial. and promote a wider species diversity and biomass production or impact the trophic levels by reducing the biomass and species diversity. Examples of environmental changes that could produce positive and negative effects are changes in turbidity, sedimentation, micronutrient levels, toxins, pH, and temperature levels. Each of these changes will promote positive or negative reactions for the individual species, which in turn will generate changes in species diversity.

\subsubsection{Aquatic Ecosystem: Physical Interaction}

ISSUE

Physical changes in the aquatic environment due to changes in temperature, flow rates, sedimentation, turbidity, and color from such activities as dredging, channelization, and ponding may create physical environmental stresses on the indigenous aquatic and estuarine species.

DE SCRIPTION

The transformation of a fen, depressed bog, or coastal peatland into a harvest area will necessitate physical changes in the aquatic ecosystem. In most 
cases, these changes may decrease habitat values during development but may improve aquatic habitat values as the result of a well designed reclamation program after harvesting. The physical impacts associated with peatland development are similar to those associated with other types of wetlands development.

\subsubsection{Aquatic Environment: Unique Aquatic Habitats}

ISSUE

Certain peatlands may have limited potential for resource development because of the ecosystem's uniqueness or the habitat provided for rare and endangered species.

DESCRIPTION

Peatlands in some areas constitute a rich and valuable assemblage of species forming a unique wetland and aquatic ecosystem. Any changes affecting rare and endangered aquatic species will have an immediate impact. 


\subsection{TERRESTRIAL ECOSYSTEM ISSUES}

One of the major environmental concerns regarding peatland energy development is the issue of terrestrial habitat removal due to the harvesting of the ecosystem. The net result of this action is that the diverse wetland flora and fauna that inhabitat these productive areas will be removed. In most cases, those areas that are potentially economically and technologically exploitable for energy purposes are generally classified as wetlands by the appropriate state and Federal agencies. The principal environmental issue raised then becomes one of peat harvesting versus wetlands protection. The land resources and the terrestrial habitat commitment necessary for a largescale plant development are indicated in Table 3.5, which also shows the land resource commitment required to support a comparable coal-fired plant in several regions of the country. This table also indicates the potentials for reclamation, the uniqueness of the ecosystem, and the probable occurrence of rare and endangered species in each of the areas.

Peatland ecosystems throughout the United States offer a spectrum of representative terrestrial ecosystems ranging from a tropical everglades to temperate depression bog to arctic open ground tundra communities. The terrestrial habitats forming these peatlands will differ markedly from location to location. The environmental concerns for a particular project will be affected by the scale of development and the value and uniqueness of the habitat. For these reasons, peat harvesting, like any other resource extraction, may arouse public and agency concerns for terrestrial wetland habitat 1 oss.

Site reclamation plans, as discussed in Section 2, will envision final use of the land for forestry, agriculture, wildlife habitat, recreation, or a combination of these and in most instances improve the use of land. In any case, because of the drainage or pondage required for resource extraction and the removal of the peat, natural terrestrial ecosystems would not be replaced. The impacts on the terrestrial ecosystem will occur during the bog preparation, extraction, reclamation, and future land use phases. 
Table 3.5 Typical Terrestrial Resource Commitments for a 800 MW Powerplant

\begin{tabular}{|c|c|c|c|c|c|c|}
\hline & $\begin{array}{l}\text { PRINCIPAL } \\
\text { HABITAT TYPES }\end{array}$ & $\begin{array}{c}\text { ECOSYSTEM } \\
\text { VALUE }\end{array}$ & $\begin{array}{l}\text { AVERAGE USE } \\
\text { PER YEAR }\end{array}$ & $\begin{array}{l}\text { RECLAMATION } \\
\text { TYPES AND } \\
\text { POTENTIAL }\end{array}$ & $\begin{array}{c}\text { UNIQUENESS } \\
\text { OF THE } \\
\text { TERRESTRIAL } \\
\text { ECOSYSTEM }\end{array}$ & $\begin{array}{l}\text { PROBABLE } \\
\text { OCCURENCE OF } \\
\text { RARE AND } \\
\text { ENDANGERED } \\
\text { SPECIES }\end{array}$ \\
\hline $\begin{array}{l}\text { EASTERN COAL SURFACE } \\
*\end{array}$ & $\begin{array}{l}\text { CUT OVER EASTERN } \\
\text { HARDWOODS. }\end{array}$ & $\begin{array}{l}\text { MODERATE TEARESTRIAL } \\
\text { ECOSYSTEM VALUE } \\
\text { ANO PRODUCTIVIVY. }\end{array}$ & $\begin{array}{l}\text { 85 ACPES PER } \\
\text { PEF YEAR. }\end{array}$ & $\begin{array}{l}\text { RECLMATION TO } \\
\text { MAROWOOD FORESS } \\
\text { IS POSSBLE MIGH } \\
\text { AATE OF SUCCESS. }\end{array}$ & nо & FEW \\
\hline $\begin{array}{l}\text { EASTERN COAL SUBSURFACES } \\
\text { * }\end{array}$ & $\begin{array}{l}\text { CUT OVER EASTERN } \\
\text { HAROWOODS }\end{array}$ & $\begin{array}{l}\text { MODERATE TERRESTRIAL } \\
\text { ECOSYSTEM VALUE } \\
\text { AND PRODUCTIVITY. }\end{array}$ & $\begin{array}{l}275 \text { ACRES SUBSURFACE } \\
\text { SMALL SURFACE } \\
\text { EXPRESSION. }\end{array}$ & $\begin{array}{l}\text { SMALL } \\
\text { PECLAMATION } \\
\text { NEEDS. }\end{array}$ & No & FEW \\
\hline $\begin{array}{l}\text { WESTERN COAL SURFACE } \\
\text { * }\end{array}$ & $\begin{array}{l}\text { MESOUITE, SAGEERUSH } \\
\text { AND SHORT SHSH } \\
\text { GRASS PANGELAND. }\end{array}$ & $\begin{array}{l}\text { MODERATE TERRESTRIAL } \\
\text { ECOSYSTEM VALUE } \\
\text { AND LOW } \\
\text { PRODUCTIVITY. }\end{array}$ & $\begin{array}{l}\text { SO ACAES } \\
\text { PER YEAR. }\end{array}$ & 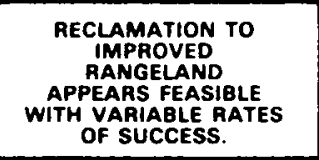 & No & FEW \\
\hline MINNESOTA PEATLANDS & $\begin{array}{l}\text { MOSS SEOGE UP_AND } \\
\text { FIRS AND SPRUCE } \\
\text { FOREST. }\end{array}$ & $\begin{array}{l}\text { MODERATE TERRESTRIAL } \\
\text { ECOSYSTEM VALUE } \\
\text { AND PRODUCTIVITY. }\end{array}$ & $\begin{array}{l}\text { 6.900 ACAES } \\
\text { PER YEAR. }\end{array}$ & $\begin{array}{l}\text { RECLAMATION } \\
\text { POTENTIAL FOA FORESTAY } \\
\text { AGRCULTURE } \\
\text { OP WIDLIIFE } \\
\text { HABITAT WITH MIGH } \\
\text { RATE OF SUCCESS. } \\
\end{array}$ & $\begin{array}{l}\text { CERTAIN } \\
\text { AREAS }\end{array}$ & FEW \\
\hline FLORIDA PEA-LANDS & $\begin{array}{l}\text { REED, TROPICAL } \\
\text { MAIE GRASS } \\
\text { MARSHLANE. }\end{array}$ & $\begin{array}{l}\text { MIGH TERAESTAIAL } \\
\text { ECOSYSTEM VALUE } \\
\text { AND PRODUCTIVITY. }\end{array}$ & $\begin{array}{l}\text { 6,900 ACRES } \\
\text { PER YEAR. }\end{array}$ & 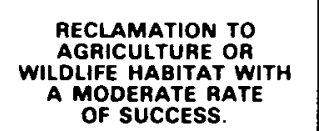 & YES & MANY \\
\hline ALASKA PEATLANOS & $\begin{array}{l}\text { MUSKEG AND EIACK } \\
\text { SPAUE FPREST } \\
\text { UNDELAN WITH } \\
\text { PERAAFAOST. }\end{array}$ & $\begin{array}{l}\text { LOWER TERAESTAIAL } \\
\text { ECOSYSTEM VALUE } \\
\text { AND PRODUCTIVITY. }\end{array}$ & $\begin{array}{l}\text { 6.900 ACAES } \\
\text { PER YEAR. }\end{array}$ & $\begin{array}{l}\text { RECLAMATION TO } \\
\text { WILDLFE HABITAT } \\
\text { WITH A MODERATE } \\
\text { RATE OF SUCCESS. }\end{array}$ & NO & FEW \\
\hline
\end{tabular}

* THE DIFECT USE OF COAL. CONGAESS OF THE UNITED STATES. OFFICE OF TECHNICAL ASSISTANCE, 1979. PG $56-65$. 
The relative magnitude of the anticipated terrestrial ecosystem issues is illustrated in Table 3.6. The issues are described below and discussed in detail in Appendix A.

Table 3.6 Terrestrial Ecosystem Environmental Issues

\begin{tabular}{|c|c|c|c|c|c|c|c|c|c|}
\hline \multirow{3}{*}{$\begin{array}{c}\text { PRIMARY } \\
\text { ENVIRONMENTAL } \\
\text { RESOURCE ISSUE }\end{array}$} & \multicolumn{9}{|c|}{ SCALES OF DEVELOPMENT } \\
\hline & \multicolumn{3}{|c|}{ SMALL } & \multicolumn{3}{|c|}{ MODERATE } & \multicolumn{3}{|c|}{ LARGE } \\
\hline & MANOA & Mö̈eate & MINOR & MAJOR & MODERATE & MINOR & ma.ina & MONGQATE & MINOH \\
\hline WILDLIFE IMPACTS & & & & & & & & & \\
\hline $\begin{array}{l}\text { ENDANGEAED SPECIES } \\
\text { IMPACTS }\end{array}$ & & & & & & & & & \\
\hline $\begin{array}{l}\text { UNIQUE PEATLANDS } \\
\text { IMPACTS }\end{array}$ & & & & & & & & & \\
\hline
\end{tabular}




\subsubsection{Terrestrial_Ecosystems: Wildlife}

ISSUE

Peatlands within the United States support diverse wetland wildlife species and provide valuable habitat. The development of peatlands may affect the wildlife population through removal of these resources during harvesting and the creation of a new ecosystem after reclamation. This issue represents important environmental concern for the overall peat energy program.

\section{DESCRIPTION}

Construction and extraction activities effectively remove the original wildlife habitat, thereby producing impacts with effects ranging from minor and temporary to major and long term depending on the species and the scale of development. There can be no question that transformation of a peatland from its natural condition will cause the direct removal of immobile species and migration out of the area of mobile species. Concomitant with development of peat resources, wildlife populations will be either temporarily or permanently displaced from the zone surrounding the actual areas of habitat disruption. Beyond these direct effects are many subtle influences on wildlife populations as a result of reclamation activities and secondary development. For example, human presence can interfere with mating, nesting, rearing, and migration and can further reduce the local wildlife populations. Changes also occur in the prey-predator relationship of carnivores and herbivores by habitat alteration or removal of selective species, both on and offsite.

Changes in the air and water environments can also generate impacts on the terrestrial ecosystem by the accumulation and transformation of toxic materials (gaseous, particulate, chemical) in the terrestrial biota and subsequent transport through the foodchain to higher organisms. 


\subsubsection{Terrestrial Ecology: Endangered Species}

ISSUE

The intensive development of peatlands could adversely impact endangered species that are dependent upon the peatland ecosystem for survival.

ENVIRONMENTAL DESCRIPTION

The direct loss of habitat, release of toxic substances, and confrontation with development are the primary reasons for the decline of species threatened with extinction. A variety of flora and fauna that are associated with peatlands are now classified as (or are candidates for classification as) rare and endangered species throughout the United States. Threatened species such as the eastern timberwolf in Minnesota, Arctic peregrine falcon in Alaska, and the everglade kite in Florida depend upon the wetland ecosytem to varying degrees. There has been concerted national effort to protect these species by identifying the individual species' range and habitat and critical features of its lifecycle. Rare flora are also commonly found in wetlands ecosystem. There is special concern that large-scale peat harvesting and the associated development in the remote areas, such as Alaska and Minnesota, could affect the migrating and feeding habitats of threatened species through changes in air and water quality. Noise generated from equipment and normal human activities that are introduced into previously undisturbed wilderness areas has been shown to have critical affects on certain species. 


\subsubsection{Terrestrial Ecosystem: Unique Peatlands}

ISSUE

Unique peatland ecosystems should be preserved for their educational, scientific, and recreational qualities.

DESCRIPTION

Certain peatlands illustrate the selective climatological and geological conditions that have resulted in the formation of unique plant and animal habitats. Protection of these areas is especially important when there are factors such as occurrence of peatland-dependent rare and endangered species, renewable natural resources, such as wild rice and timber, and sociological and historical, factors, such as science, education, and recreation. In Minnesota, the Lake Agassiz Peatlands is designated as a Natural Landmark because of the unusual natural phenomenon that formed it. Likewise, the Everglades in Florida is protected as a National Park because of its unique tropical-mire ecosystem. Michigan has a number of swamps, bogs, and forest areas that are being evaluated, for designation as Natural Landmarks. In all states, there are peatlands presently protected or being evaluated for inclusion in state and Federal preservation programs. 


\subsection{HEALTH AND SAFETY ISSUES}

Health and safety, issues include worker exposure to physical and chemical hazards and public exposure to hazardous effluents. Accidents that expose workers to physical hazards or to release of hazardous chemicals could also result in effluents that expose the public to health hazards. Chronic health effects from low-level release of substances are also health and safety issues. Existing and developing Federal, state, and local regulations, along with industrial codes and practices, are expected to deal effectively with health and safety issues related to peat utilization once these issues are wellsharacterized.

The processing of peat to produce solid fuels for direct combuslion, to produce low/medium Btu fuel gas, or to produce SNG can be expected to produce most of the hazardous substances associated with coal-conversion technologies, but in significantly smaller quantities. These hazardous substances include polynuclear aromatics (PNA), phenols, thiophenes, aromatic amines, and soluble heavy metal compounds and complexes. Fugitive losses and leaks may result in levels of hazardous materials that require specialized operating procedures and industrial hygiene and safety procedures. The occupational hazards that may result from peat processing for energy include:

- Physical contact with, or inhalation of, potentially carcinogenic or toxic by-products, waste streams, fugitive emissions, and dust;

- Potential for explosions or fires from malfunction of high-pressure or high-temperature equipment and accidental or spontaneous ignition of combustible materials, including stored or stockpiled peat;

- Potential for bog fires due to their drained condition and ignition sources associated with harvesting activities;

- Exposure to high temperatures, vibration, and noise within certain areas of a plant; 
- Physical danger of contacting high-temperature equipment or corrosive materials and working on elevated equipment; and

- Exposure during maintenance and turnaround operations to process equipment and materials containing potentially carcinogenic compounds.

None of these hazards, including other health and safety hazards associated with peat harvesting, are wholly new, and most are somewhat more serious for coalconversion than for peat conversion. It is expected that the intense effort currently underway to identify and characterize the health and safety issues associated with coal-conversion technologies will also help resolve most of the issues associated with the use of peat for energy.

There are, however, a few health and safety issues uniquely associated with peat. Milled-peat or sod-peat harvesting and dry peat transportation and storage could result in worker and public exposure to fugitive peat dust. Peat dust explosions and fires, and peat bog fires (which are associated with European harvesting methods), are also unique to peat utilization. Bioconversion of peat does not have a analog in coal-conversion technology. Nevertheless, most peat-associated hazards, and issues may be similar to those associated with coal conversion.

The relative importance of these issues are indicated in Table 3.7. The issues are described below and discussed in detail in Appendix A.

Table 3.7 Health and Safety Environmental Issues

\begin{tabular}{|c|c|c|c|c|c|c|c|c|c|}
\hline \multirow{3}{*}{$\begin{array}{c}\text { PRIMARY } \\
\text { ENVIRONMENTAL } \\
\text { RESOURCE ISSUE }\end{array}$} & \multicolumn{9}{|c|}{ SCALES OF DEVELOPMENT } \\
\hline & \multicolumn{3}{|c|}{ SMALL } & \multicolumn{3}{|c|}{ MODERATE } & \multicolumn{3}{|c|}{ LARGE } \\
\hline & maNor & modemate & MIMOR & MANOR & MODERATE & Minon & MNON & MODERATE & MimOR \\
\hline $\begin{array}{l}\text { DUST EXPLOSION } \\
\text { \& FIRES }\end{array}$ & & & & & & & & & \\
\hline PEAT FIRES & & & & & & & & & \\
\hline $\begin{array}{l}\text { METAL CARBONYL } \\
\text { EMIBSIONS }\end{array}$ & & & & & & & & & \\
\hline $\begin{array}{l}\text { TRACE ELEMENTS } \\
\text { EMISSIONE }\end{array}$ & & & & & & & & & \\
\hline $\begin{array}{l}\text { ORGANIC CARCINOQEN } \\
\text { EMIBGIONS }\end{array}$ & & & & & & & & & \\
\hline
\end{tabular}




\subsubsection{Health and Safety: Dust Explosions and Fires}

ISSUE

Suspended dusts of combustible materials can burn or explode under certain conditions, exposing workers to fire or explosion hazards.

\section{DESCRIPTION}

Harvested peat dust or peat-fuel dust might burn or explode if sufficiently fine, dry, and concentrated in air; explosion is especially dangerous if it is enclosed in a storage or transportation container. Any ignition source, such as a electrical discharge or a lighted cigarette, might initiate a fire or explosion. The ubiquitous nature of ignition sources makes dust suppression the most effective control measure.

\subsubsection{Health and Safety: Peat Fires}

ISSUE

Drained peat bogs are susceptible to bog fires, which can be ignited by harvesting equipment or careless handling of smoking material. Stored or stockpiled peat can also be ignited or burn from spontaneous combustion.

\section{DESCRIPTION}

Peat is in a very early stage of coalification and can be easily ignited if sufficiently dry. Stored or stockpiled peat is also susceptible to biological oxidation when exposed to air; temperatures can build up during this biological oxidation and result in spontaneous ignition. Autoignition of dried peat can occur during transport if air is allowed to enter the material. Mitigation measures include elimination of ignition sources, reduction of oxygen levels in storage containers, fire detection systems, and deluge systems. 


\subsubsection{Health and Safety: Metal Carbonyls}

ISSUE

Toxic carbonyls of transition metals might be produced during peat conversion to fuel gases:

DESCRIPTION

Gaseous carbon monoxide can combine with transition metals to form volatile, toxic carbonyls. Iron, nickel, and cobalt carbonyls are considered the most important because of the presence of these metals in catalysts and structural materials. These carbonyls are toxic in very low doses, if breathed, and nickel carbonyl is believed to be carcinogenic. Fortunately, these carbonyls are formed only over narrow temperature limits at high carbon monoxide partial pressures and readily decompose in air. They nevertheless can be hazardous to onsite workers if fugitive leaks are adjacent to work areas or if maintenance activities take place in confined areas that lack proper ventilation.

\subsubsection{Health and Safety:- Trace Elements}

ISSUE

Certain trace elements present in peat, especially heavy metals, can be hazardous to health.

\section{DESCRIPTION}

A number of trace elements that are found in peat are harmful in certain chemical combinations and can, in some cases, travel rapidly through the soil. Precaution against the leaching of these chemicals from solid waste disposal sites is therefore necessary. Leaching can result in public exposure to these harmful chemicals, especially if groundwaters used for human consumption are contaminated. 


\subsubsection{Health and Safety: Organic Carcinogens}

ISSUE

Peat-fuel, peat-derived fuels, and potential solid and liquid by-products from gasification may contain detectable levels of polynuclear aromatics (PNA) and other organic compounds that are carcinogenic.

\section{DESCRIPTION}

Peat, peat-derived products, and byproduct solids and liquids may contain detectable levels of PNA carcinogens that are very refractory in the air and water environment. Their release into the environment and into the work place must be carefully controlled to extremely low levels.

Recycling of solids and liquids back to gasifiers or to thermal destruction would greatly limit their release. Special worker precautions taken when working on opened equipment will also be required. If not properly controlled solid or liquid fuel products containing PNA and other carcinogens could pass the hazards into uncontrolled end uses, resulting in exposure of the public. 


\subsection{REGULATORY ISSUES}

Peat development, with its inherent requirements for energy facility siting, surface harvesting, wetlands construction, high seasonal employment factors, large land clearing operations, air and water discharges, and reclamation, should expect to receive vigorous regulatory scrutiny. The delays and controls these regulatory issues pose in the decision-making process may ultimately affect the viability of a given project in the views of prospective sponsoring entities.

As in most projects, the magnitude of the development will determine the degree of complexity in obtaining the necessary regulatory approvals. The primary regulatory hurdles for any scale of peatland development will be the state and Federal regulations for wetlands protection, surface water pollution discharges, and air quality maintenance standards. The secondary regulatory issues will focus on hazardous waste disposal, health and safety, Coastal Zone Management, and broad NEPA regulations.

Existing and developing Federal, state, and local environmental regulations are expected to require few modifications to meet the new challenges of peat energy development. Certain unique aspects of peat utilization can be expected to necessitate some modifications to regulations once the significant environmental issues and processes are well characterized: Existing relevant Federal legislation is listed in Appendix B. Revelant state and local regulations are more site specific; however, they do not substantially differ from Federal regulations.

The relative importance of regulatory issues that may affect peat energy development to a considerable degree is indicated in Table 3.8. These issues are described below and discussed in detail in Appendix A. 
Table 3.8 Regulatory Environmental Issues

\begin{tabular}{|c|c|c|c|c|c|c|c|c|c|}
\hline \multirow{3}{*}{$\begin{array}{l}\text { PRIMARY } \\
\text { ENVRONMENTAL } \\
\text { RESOURCE ISSUE }\end{array}$} & \multicolumn{9}{|c|}{ SCALES OF DEVELOPMENT } \\
\hline & \multicolumn{3}{|c|}{ SMALL } & \multicolumn{3}{|c|}{ MODERATE } & \multicolumn{3}{|c|}{ LARGE } \\
\hline & MANOR & MOdERATE & Mimon & Mavor & MOOERATE & MiNOR & MANOR & MODERATE & MINOA \\
\hline $\begin{array}{l}\text { WEELANDS PROTECTION } \\
\text { ISSUES }\end{array}$ & & & & & & & & & \\
\hline $\begin{array}{l}\text { AIR QUA:ITY NON } \\
\text { ATTAINMEMT ISSUES }\end{array}$ & & & & & & & & & \\
\hline $\begin{array}{l}\text { PREVENTION DF SIGNIFICANT } \\
\text { DETERICRATION ISSUES }\end{array}$ & & & & & & & & & \\
\hline $\begin{array}{l}\text { HAZARDOUS NASTE } \\
\text { REGULATIONS Q ISSUES }\end{array}$ & & & & & & & & & \\
\hline $\begin{array}{l}\text { ENVIRONMENTAL ASSESSMEN } \\
\text { REGULATION ISSUES }\end{array}$ & & & & & & & & & \\
\hline
\end{tabular}




\subsubsection{Wetlands Protection Issues}

ISSUE

Because of the biological importance of wetlands and their substantial reduction throughout the United States in the last 30 years, various state and Federal laws have been enacted to offer umbrella protection for the remaining wetiand habitats.

DESCRIPTION

In most cases, environmental and land managment agencies of the state and Federal governments will classify the majority of the peatlands as wetland habitats. Peatlands placed in this land use status will then come under close scrutiny, and substantial benefits to the state must be demonstrated before the necessary land use permits could be secured. The majority of the ten states studied for this report indicated that the wetlands issue would have to be resolved before any large-scale peat energy development could be started.

\subsubsection{Non-Attainment Regulations}

ISSUE

Regulations stemming from the Clean Air Act and its latest amendments could limit new emissions sources from being built in areas that are currently nonattainment for certain criteria air pollutants.

DESCRIPTION

New atr emission sources are prohibited in areas that do not meet National Ambient Air Quality Standards (NAAQS) unless Emission Offsets (EO) from existing sources can be achieved. Offsets would be difficult to find in most peat-rich areas. Fortunately, air quality non-attainment is not a problem in many peatrich areas, largely because of their remoteness from population centers. 


\subsubsection{Prevention of Significant Deterioration Regulations}

ISSUE

Regulations stemming from the Clean. Air. Act and its latest amendments could prevent new emission sources from being built in NAAQS attainment areas unless they apply "best available control technology" (BACT) and would not cause significant deterioration of existing air quality.

DESCRIPTION

Significant deterioration is defined according to designated air quality classes, ranging from PSD Class I to PSD Class III, with PSD Class I being the most restrictive. All of the United States, except for certain wilderness areas, was originally assigned to PSD Class II. Redesignation to PSD Class I or PSD Class III is possible. Each of these PSD Class designations has a specified allowable incremental increase in air emissions from new sources and modified sources.

\subsubsection{Hazardous Waste Regulations}

TSSIIF.

The Resource Conservation and Recovery Act (RCRA) and the Toxic Substances Control Act (TSCA) are evolving regulations for the control of hazardous substances. Peat energy projects are expected to produce some hazardous substances as products or byproducts that would be subject to these regulations.

\section{DESCRIPTION}

TSCA regulates products and RCRA regulates wastes. Hazardous materials are to be followed from "cradle to grave" (and beyond) to prevent undetected exposure of the public. Monitoring and special handling and disposal facilities are required by these regulations. 


\subsection{0:5 Environmental Assessment Regulations}

ISSUE

The National Environmental Policy Act (NEPA) and similar state laws require full disclosure of predicted environmental impacts from certain new projects.

DESCRIPTION

Certain actions by agencies of the Federal government must be preceeded by the development of an EIS. An EIS is a full disclosure of the predicted environmental impacts of the proposed project. This EIS must be considered during the decisionmaking process. The EIS is open to public review, comment, and opposition. 


\subsection{SOL ID WASTE DISPOSAL ISSUES}

The development of peatlands for the production of energy will generate solid waste residuals from the harvesting and processing phases. Peatland development will produce organic solid waste streams primarily from the bog preparation phase and inorganic ashes from the energy processing. An order of magnitude estimate of these wastestreams is 0.25 to 0.5 cubic feet of organic material per square foot of bog cleared and 4 to 15 percent inorganic ash residue of the amount of peat consumed on a dry weight basis. The environmental aspects of these respective types of wastestreams are described below and discussed in detail in Appendix A.

\subsubsection{Disposal of Organic Solid Waste Residues}

ISSUE

The clearing of natural peatlands for energy production will require the removal of all live native vegetation and of the upper peat deposits that are not sufficiently humified to be a suitable energy feedstock. The disposal of this organic material constitutes an environmental concern that must be addressed separately for each individual peat project.

\section{DESCRIPTION}

The volume of living biomass and surficial organic material can vary from very small amounts, as in a treeless tundra or reed marsh bog, to very large quantities where the peat deposits are overlain with shrub, spruce, cedar, or cypress forests. The disposal or reuse of this matter for energy, agricultural, or reclamation purposes constitutes a moderate environmental concern. The handling of the organic residues must be designed to limit flooding, insect infestations, fire, and disease. 


\subsubsection{Disposal of Process Slag and Flyash}

ISSUE

- Four to fifteen percent of dry peat energy feedstock consists of inorganic materials that form an ash or slag from the boiler or gasification facility or flyash from particulate air pollution control equipment. The disposal of this material will come under close agency and public scrutiny.

DESCRIPTION

All peat conversion routes will produce process solid waste. The volume of this waste stream will be primarily a function of the initial peat ash content. The chemical constituents of the stream will be a function of the natural constituents and process emission losses. Chemical analyses of peats have indicated that the inorganic constituents, are primarily composed of $\mathrm{Si}, \mathrm{Ca}, \mathrm{Al}, \mathrm{Fe}, \mathrm{Mg}$, $\mathrm{K}, \mathrm{P}, \mathrm{Na}, \mathrm{S}, \mathrm{V}, \mathrm{N}, \mathrm{Pb}, \mathrm{Mn}, \mathrm{Cu}$. Research on direct combustion flyash in Finland has indicated that material may be used as a building material or as a soil conditioner. For moderate- and large-scale facilities, use as a reclamation soil conditioner would be the most probable disposal method. 


\subsection{SECONDARY DEVELOPMENT ISSUES.}

The development of a moderate- or large-scale peat energy development scheme in a remote area will generate secondary development issues that may be either beneficial or harmful to the surrounding environment. Peat development, like many of the more recent energy development programs, will introduce of new technologies, jobs, and capital into a region that may not be prepared for them. The ensuing rapid development may place heavy stress on the community structure in addition to creating sharply increased use of the areas air, water, and terrestrial resources. These factors are fully discussed in the DnE sponsored socioeconomic study conducted by the Radian Corporation. 


\section{SECTION 4 - STATE ANALYSIS}

\section{$4.1 \cdot$ INTRODUCTION}

This section discusses the general environmental issues, resource availability, and state attitudes associated with potential peat development. Ten states, containing an estimated 90 percent of U.S. peat resources, were selected for this analysis; it is expected that other states having peat resources would have similar peat development concerns. The ten states reviewed are Alaska, Minnesota, Michigan, Maine, North and South Carolina, Wisconsin, New York, Florida, and Louisiana. The first six of these are currently participating in the DOE-sponsored peat resource analysis. In general, the states vary in their degree of awareness of and activity on peat energy development, but each state is aware of the need to determine the most beneficial use of peatlands for its needs. In the future, additional states may conduct peat resource analyses.

The management of the individual state peat resources is inexorably linked with state and Federal regulations concerning wetland management. The only two states where this may not be true are Alaska and Minnesota, which have extensive upland peat deposits that may not be defined as wetland ecosystems. State peat management options are for nonconsumptive preservation; low-level consumption for crop and forest production; or full consumption for horticultural and energy extraction purposes. Because of the diversity of these alternate management options, the formation of a state peat energy resource development policy is difficult and must involve a large number of varying interests within the state.

The environmental concerns and issues found by analys is of individual states were generally shared by all the states. The principal environmental issues were the consumptive use of wetlands and the general. concerns generated by any wet land development project. 
The States of Michigan, South Carolina, and Louisiana are reviewing the resource and environmental issues to formulate a more definitive policy and course of action.

The resource and environmental evaluation and formulation of a definitive state peat energy policy, as the State of Minnesota has demonstrated, is not a simple process. At the center of this decision process is the central question of development versus nondevelopment within these natural peatland (wetland) areas. The final state and Federal positions on this question will he further tempered by public sentiments when a specific project is proceeding through the environmental review process. With the exception of Minnesota, the states have not. pursued any further comprehensive analysis of the environmental issues ident $i-$ fied in section 3 of this report.

The following state profiles provide a summary' of the peat resources and the environmental setting with regard to resource development and related state policies, interests, and programs.

In the presentation of peat resource areas of each state, the peat areas have been broken down into three general classes. A Class I area contains large or moderate sized peat deposits in semicontiguous peatlands; a Class II area contalns moderate sized peatlands in close to moderate proximity to each other; and a Class III area contains only isolated peatlands or small peat bogs. Areas not classified contain insignificant amounts of peat. 


\subsection{ALASKA}

\subsubsection{Resources}

The State of Alaska contains the largest peat resource within the U.S. The muskeg, tundra, and tiaga areas of Alaska provide unique environmental settings that promote the accumulation of organic litter because of the poor drainage and the subarctic and arctic climatic conditions that minimize microbial decomposition. These peatland types are similar to the arctic and subartic bog patterns that occur in the northern latitudes of Canada, Northern Europe, and the U.S.S.R. $(70,75)$

No current inventory of Alaska peat resources exists. The reasons for the general lack of data are the remoteness of the region and the availability of more valuable resources (oil and gas). Dachnowski and Stokes conducted a brief survey of deposits in Alaska along the Panhandle, across Seward Peninsula, and along the Alaska Railroad to Fairbanks. (108) Their studies showed that small, deep peat deposits occur along the coastal areas and shallower, multilayered deposits occur in the central interior. As shown in Figure 4-1, the potential development of peat within Alaska would be severely constrained by the continuous and noncontinuous permafrost that underlies the majority of the Alaskan interior. In addition, plans for extraction of peat must consider the extremely long winters and short summers.

Although the actual amount of peat reserves in Alaska may be in error by orders of magnitude, the fact remains that sufficient resources are available for any level of development. Peat quality with respect to high humification and complete decomposition necessary for the production of a high Btu feedstock may not be as complete as in other states with warmer climates. (108) The growth and decomposition of peat is slower in Alaska than in more temperate climates; consequently, the deposits may be shallower and less decomposed. As shown in Figure 4-1, the deeper deposits would be generally associated with the riverine lowland throughout the discontinuous permafrost zone. Within these areas, the muskeg (peatlands) is wet and forms a noncontinuous drainage system interspersed 


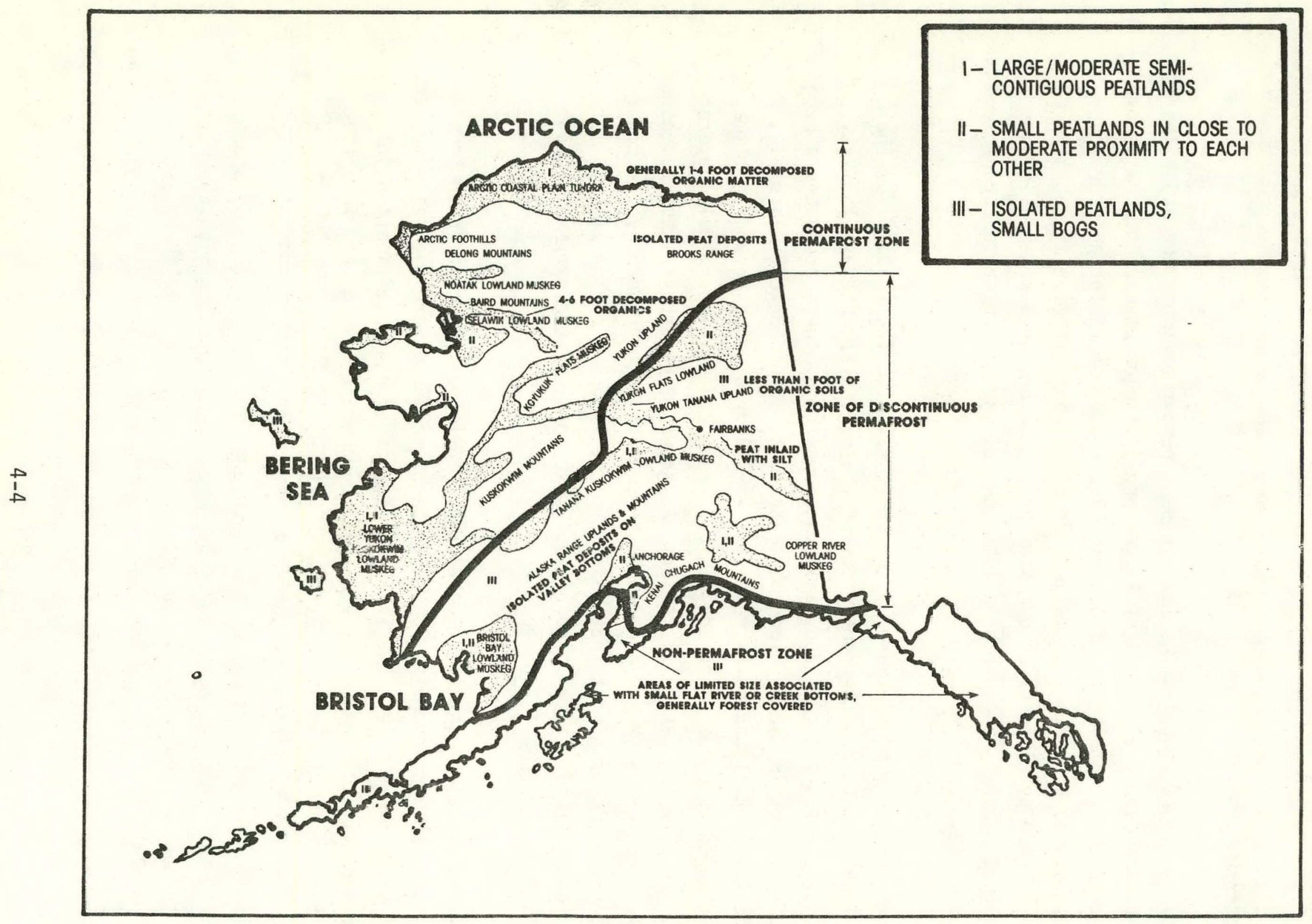

Figure 4-1 Alaska Peat Resource Areas 
with numerous lakes. The flat, treeless arctic coastal plain contains several feet of organic materiat in permafrost. $(29,39,102)$

\subsubsection{Attitudes and Concerns}

The fact that Alaska has the largest peat resource does not necessarily lead to large-scale development when the economic, environmental, and competing energy resource alternatives are evaluated. Alaska, unlike any other state, has a difficult environment for extraction of mineral and energy resources. The remote location of the resources, in conjunction with the subarctic and arctic climates, poses difficult engineering requirements. The current state program is investigating the potential for small, scattered projects in the Matanuska and Lower Kuskowkwim River Valleys. Peat energy projects within Alaska would offset dependence an expensive fuel oil within the remote communities. The use of peat for the generation of heat and electrical power could prove feasible on a local basis.

- Peat harvesting in an arctic and subarctic environment can be conducted for only 20 to 50 days by dry harvesting methods. With the correct type of drained muskeg or tundra peatland, it is anticipated that sufficient peat harvesting and storage could be conducted for small energy facilities during the sumnertime 24-hour daylight period.

Table 4.1 provides a summary of the known energy development factors in Alaska that was derived from the survey conducted for this study. 
Table 4.1 Alaska Peat Development Factors

(page 1 of 3 )

\section{PEAT RESOURCES}

Largest peat resource in the United States.

Fuel grade quality of peat must be determined.

Peat resources are generally available for all interior and coastal communities with the exception of the panhandle area.

Peat resources are available to meet the small interior Alaska energy requirements.

\section{ENERGY DEVELOPMENT ATTITUDES}

The villages having a potential for use of electricity and heat would vary in population from 300 to a maximum of 3,000 people.

Alaska has an energy development prospectus that considers the use of peat for remote, small-scale use:

Current peat resource program will evaluate peat in Lower Kuskowkwim and Matanuska River valleys for moderate scales of development.

State/Federal/Native claims conflict on designation of land ownership and use of Federal lands.

Strong. local interest would be expected for peat energy development in remote settlements. 
Table 4.1 Alaska Peat Development Factors

(page 2 of 3 )

Peat has been recognized as a fuel for remote areas since the early 1900 s.

Native Corporations could provide a stimulus for development of energy selfsufficiency.

\section{ENVIRONMENTAL CONCERNS}

Permafrost is a problem except south of Alaska Range and along the Aleutians.

Because of the arctic climate and permafrost conditions, harvesting of peat would be very seasonal.

Potential effects on anadromous fishery resource and wildlife habitat (large mammals) is both environmentally and politically a sensitive issue.

Potential conflict with caribou in western Alaska with large-scale peat operation.

Large-scale operations would be remote, which would require the construction of new access and communities.

PSD requirements will apply to significant portion of Alaska as the result of PSD Class I designation for Federal lands, natives, etc.

Moderate and large peat developments within the coastal areas will require coordination with the State's coastal zones management program. 
Table 4.1 Alaska Peat Development Factors

(page 3 of 3 )

\section{ALTERNATIVE ENERGY PROGRAMS}

State has ample gas, oil, coal, and hydro-electric power to meet needs and is a net energy exporter.

Only the Anchorage, Kenai, and Matanuska areas have a gas distribution system.

Fuel oil costs in remote areas can be two to three times the contiguous United States costs.

Wood, wind, and solar energy generation schemes are being considered às alternatives in Alaska.

\section{OTHER FACTORS}

Most energy and mineral resources are remote, and no processing industry exists.

Remote locations are primarily native-controlled with respect to the land resources.

Costs for construction and operation of any facility would be probably exceed those in the contiguous United States.

Large scale development would come under both siate and National, review because of the strong environmental concerns in the nation regarding Alaska and development in the "last wilderness."

Canadian engineering studies have indicated that the annual production hours per year diminish from 350 hours at the $34^{\circ}-32^{\circ}$ Mean Daily Isotherm to 90 hours at the $26^{\circ}-24^{\circ}$ i sotherm. (103) 


\subsection{MINNESOTA}

\subsubsection{Resource}

Minnesota contains the nation's second largest peat resource (estimated at 7.6 million acres). These reserves have received the most attention and research for energy production within the U.S. The estimated reserves are sufficient to supply the requirements of a large peat-energy production program. The Minnesota peatland forms a southern lobe of a mire complex, as defined by Radforth, that is part of the largest Canadian peat mire complex and is considered to be morphologically similar to the central European and West Central Russian mires. The majority of the Minnesota peatlands are formed within the drained Glacial Lake Agassiz area in Northern Minnesota. The southern deposits have been developed similarly by the poor glacial drainage patterns following the glacial retreat. These depression deposits, however, are isolated and not as large as the northern deposits. $(38,75)$

The suitability of the peat deposits for energy production is being carefully evaluated by the State of Minnesota for inclusion into the comprehensive Minnesota Peat Program. A summary of a recent peat resource and environmental review is given in Figure 4-2.(54) There are approximately 3 million acres of fuel grade peat with a depth greater than 6 feet. These reserves, located in northern Minnesota, are in the Class I areas. The average peat fuel quality has been determined to be approximately 9,000 Btu/lb (oven dry weight) and $7.000 \mathrm{Btu} / \mathrm{lb}$ with $30-40 \%$ water. The difference in energy value between sapric and fibric (sphagnum peat) was determined to be less than 15 percent; thus, once harvesting commences, it would be expedient to use all peat types with the exception of the living mat and the low density sphagnum peat near the surface. (31)

of the 7.6 million acres of peatland within the state, approximately 3.8 million acres are nondeveloped public and private lands. The remainder is in one of the following categories of use: Indian reservations; recreation; wildlife; forest; and agricultural and commercial horticultural peat production. 


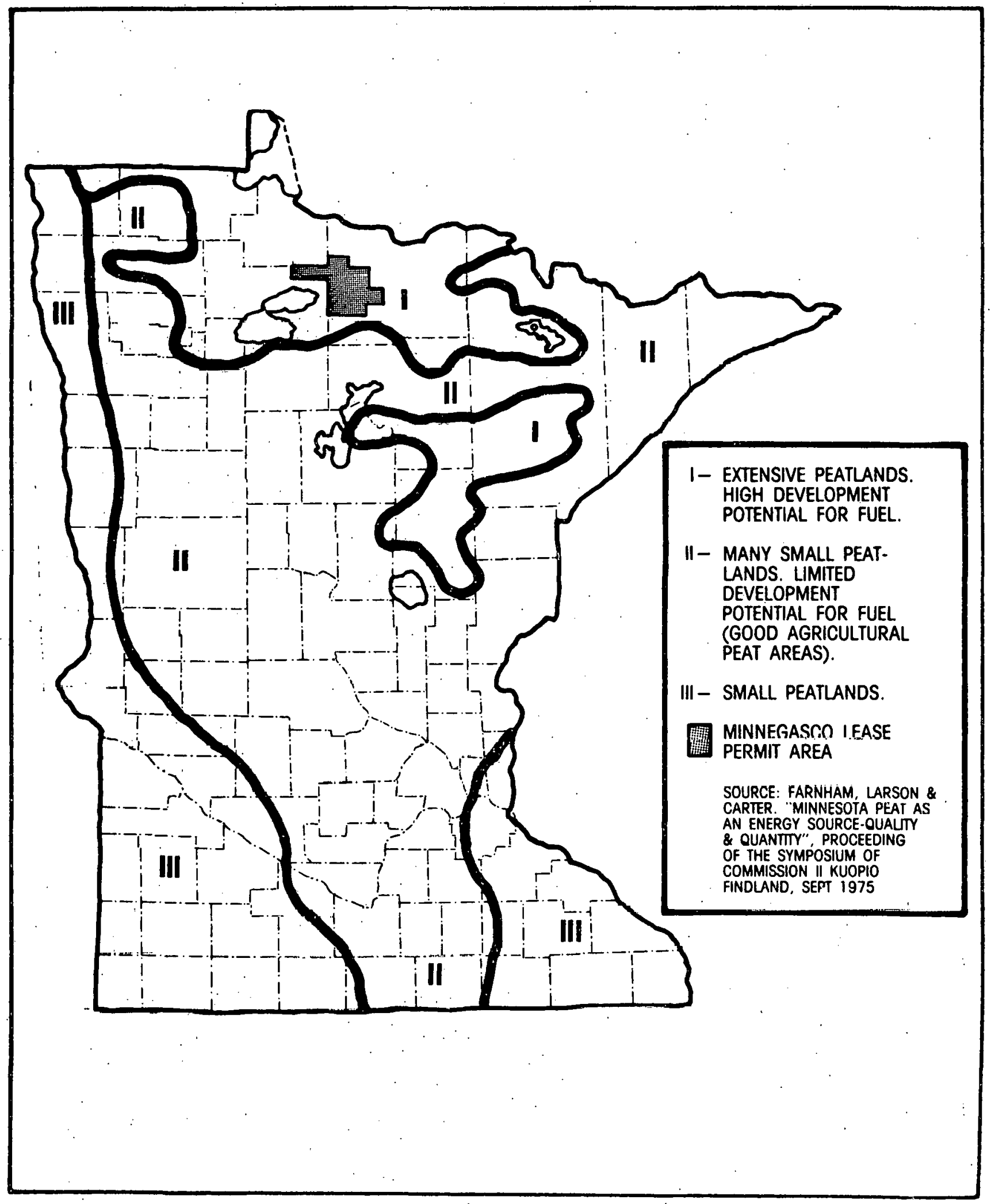

Figure 4-2 Minnesota Peat Resource Areas 
The use of peat for energy is being considered by Minnesota because of the large intrastate energy requirements, sizable state-owned peat resources, and current application by utilities for the use of peat for SNG production. With this stimulus, Minnesota would be expected to continue its interest in peat energy development and policy formulation.

\subsubsection{Attitudes and Concerns}

Minnesota, with the largest peat reserves in the conterminous United States; is also the state having the most experience in formulating policies and programs for the use of peat for energy development. The principal environmental issues that have arisen in Minnesota are shown. in Table 4.2. As other states devel.op peat programs, they can be expected to encounter similar issues.

It is apparent from Table 4.2 that the major environmental concerns are the scale of development and the commitments of resources (land, manpower, equipment and capital) for projects presently being proposed.

Minnesota's peat resources could no doubt support several large-scale development schemes; however, the environmental resources required for any one such development would be greater than for any other single energy development scheme presently considered within the U.S. Accordingly, Minnesota is formulating its development policies very carefully. (66) 


\section{PEAT RESOURCES}

Second largest peat resource in the country (after Alaska); most of the land is state-owned.

Peat is generally a fuel grade and has a depth in excess of six feet.

The state has the peat resources to support simultaneous development of several large SNG Plants for a 20-year period.

The state has widespread peat resources that would allow various scales of development.

\section{ENERGY. DEVELOPMENT ATTITUDES}

Private industry has applied for land use permits for large-scale SNG development on state lands.

Minnesota is the most active of all states in developing a peat policy and has conducted a series of studies on peat utilization.: Current policy indicates a willingness to promote small to moderate development; large-scale development is still under review.

Since the state owns the majority of peatlands, it would be expected to set the precedent for peat development on private lands.

Indians have stated, in general, that they do not want development on or near their land. 
Table 4.2 : Minnesota Peat Development Factors

(page. 2 of. 3 )

Gas supplies from a proposed SNG facility could be used fully intrastate.

Interstate gas or energy sales does not appear to be acceptable.

Three years of research on peat issues have been conducted by Minnesota, but no formal development policy has been formulated.

Because of the expanse of the state's northern peatlands, they are not considered as a unique entity that will preclude development.

Peat development is expected to occur; only the scale of development and policies the state will formulate are in question.

\section{ENVIRONMENTAL CONCERNS}

U.S. Fish and Wildlife service is especially concerned with ensuring that the reclamation procedures to be followed in peatland will enhance wildlife values.

In general, the state may be conservative about developing the north country because it is the recreational center for the state.

Drainage of peatlands may have areawide effects on water quality and water resources, especially near Indian reservations.

\section{ALTERNATIVE ENERGY PROGRAMS}

There are no other in-state fossil energy resources.

Minnesota uses natural gas extensively for domestic heating and has a large distribution system. 
Table 4.2 Minnesota Peat Development Factors

(pàge 3 of 3 )

The state relies on small electric power plants and currently has 25 electric power plants below a 100 MW capacity.

Peat development could aid the area by reducing the importation of natural gas, oil; and coal and provide more Minnesotans with employment.

\section{OTHER TACTORS}

Peatlands are not in the Coastal Zone Management Program.

Acceptable transportation and infrastructure exists for several moderate-sized power plants.

Engineering studies within the state have indicated that the conversion of industrial boilers to burn peat would be economically practical in certain situations. 


\subsection{WISCONSIN}

\subsubsection{Resource}

Peat deposits in Wisconsin range in size from several acres up to 32,000 acres (near the town of chester). Although the majority of sites are less than 1,000 acres, there are several moderate-sized areas ranging in size from 5,000 to 32,000 acres. 01 der studies of peat conducted in the 1920's indicated a total peat acreage of 121,220 acres containing 758,165 acre feet or 151,633,000 short tons of peat. $(44,81)$ However, evaluation of the peat resource in wisconsin by Soil Conservation service (1967) has estimated the resource at 2.8 million acres. (51) The major peat counties, as shown in Figure 4-3, are Adams, Jackson Wood, Juneau, Green Lake, Marquette, Monroe, Wausau, Iran, Ashland, Price, Oneida, Sawyer, Vilas, and 0conto. Because of the similarity of climate and geomorphic development, the quality and type of peat deposits would be expected to be similar to those in Minnesota. (44)

The location of the major peatlands is centralized within the state and could facilitate smal1- and moderate-scale development for the numerous municipalities within the region.

\subsubsection{Attitudes and Concerns}

The peat resources in Wisconsin, although not as large as those in Minnesota and Michigan, do warrant serious consideration for contributing to energy supplies. To date, however, the state has not considered it because of the large amount of peatlands in agriculture, emphasis on renewable sources, such as wood, and increasingly strong protection attitudes concerning wetlands. This attitude is reflected in the factors summarized in Table 4-3. With the State's growing dependence on nuclear power, and with the predominant ownership of the peat resources' being in the private sector, there has thus far been 11ttle incentive for the State to venture into formulating a decisive peat policy. The potential for peat development would most likely be in the industrial sector for sinall-capacity units or potentially within the utility sector 


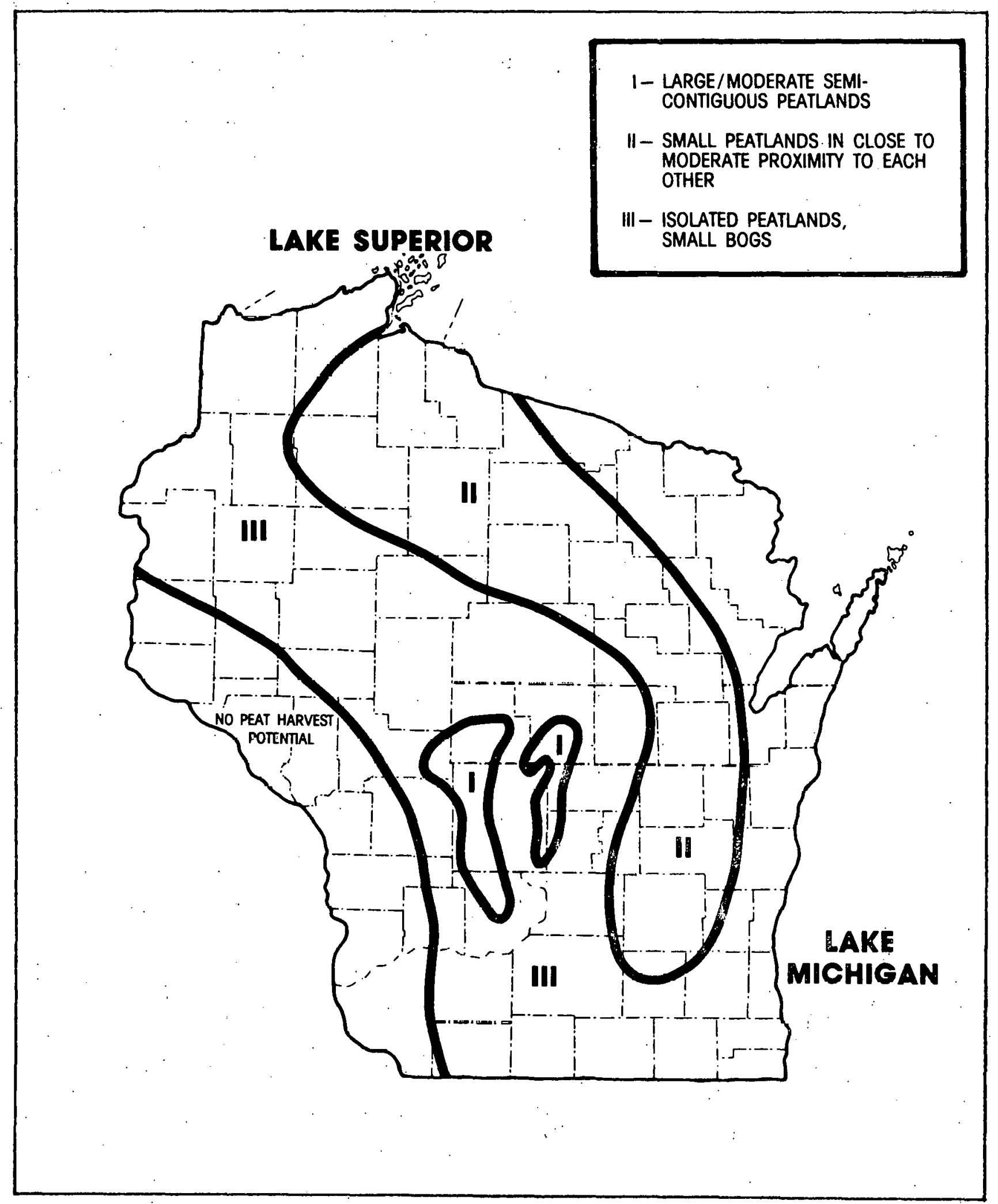

Figure 4-3 Wisconsin Peat Resource Areas 
for electrical or moderate scales of SNG production. It is expected that project siting and viability would be handled through the normal environmental review process and not require a specific peat development policy.

Wetlands and water resource protection are important environmental issues within the state. Since there has already been a significant amount of wetland drainage, Wisconsin has a strong preservation attitude against further reduction of these sensitive ecological areas. 
Table 4.3 Wiscons in Peat Development Factors

(page 1 of 2)

\section{.PEAT RESOURCES}

Peat resources within the state are small to moderate in size.

Very few peatlands within the state have the peat volumes to supply a large SNG or electric generation facility.

Peat development for agricultural and horticuitural purposes is not an extensive industry within the state.

\section{ENERGY DEVELOPMENT ATTITUDES}

There is a State Division of Energy, but no formal study exists on the use of Wiscons in peat for energy.

Stàte does not have a peat development program.

State would have potential use for multiple smal1- and moderate-sized facilities.

State has created a new Office of Mining, which will have peat harvesting under its jurisdiction.

\section{ENVIRONMENTAL CONCERNS}

Originally wetlands consisted of 10 million acres; now, only 2.8 million remain. The state owns 0.27 million, 1.6 million are privately owned, and the Federal and local governments have the remainder. 
Table 4.3 Wiscons in Peat Development Factors

(page 2 of 2 )

Wetlands, water resources, and environmental protection are very strong issues within the state.

Wiscons in has many scattered wildlife and natural areas located on or adjacent to peatlands.

There is no formal peatland or wetland management office; a revision of the Code of Wetland Protection is in preparation.

There may be strong opposition on the part of interest groups in development of wetlands.

The use of peat for energy may be questioned because wood is plentiful, and significant effort has been expended in the state to develop renewable energy sources.

\section{ÄLTERNATE ENERGY PROGRAMS}

Currently there is no energy production of oil, gas, or coal in the state, but hydroelectric, nuclear, and coal-fired power plants and a natural gas transmission system are extensive.

Wiscons in currently has 35 power plants below 100 MW capacity.

A wood-burning power plant is operating in Superior, Wisconsin.

Forly percent of the homes in northern Wiscons in are heated by wood.

Many schools are being designed to use wood heating systems; many industrial plants use wood for steam and heating. 


\subsection{MICHIGAN}

\section{5 .1 Resources}

The State of Michigan has an estimated 4.5 million acres of peatland and is currently the largest peat producer in the United States. (51) Its 1977 horticultural and bulk peat shipments were 268,000 tons, or approximately 19 percent of the total U.S. production. (79) Peat sources in the Upper Peninsula are the southern end of the Canadian mire complex. Although not contiguous, they have undergone similar morphological development. (75) As shown in Figure 4-4, the majority of the large. peatlands are located in the eastern Upper Peninsula in Schoolcraft, Luce, Chippewa, Menominee, and Mackinac counties. Resource evaluations are currently being conducted in these areas.

Peat deposits in the Lower Peninsula seldom exceed 400 acres and have experienced considerable development for agricultural purposes. Recent data indicate that $3 / 4$ of 211 the state reserves are located in the Upper Peninsula and have depths ranging from four to eight feet. The fuel value of these peatlands ranges from six to nine thousand Btu per pound. In the Lower Peninsula, large sections of organic soils exist but have been reported not to possess good fuel grade characteristics. $(30,100)$

\subsubsection{Attitudes and Concerns}

The peat resources in Michigan are sufficient to accommodate a number of small and moderate-sized facilities and possibly a large-scale facility in the Upper Peninsula.(58) With large peatland areas under state and Federal ownership, a unified peat development program would be required. If development occurs in the Upper Peninsula, Federal peat leasing policies will have to be established for National Forest lands that contain extensive peat reserves.

Within the state, there is a general optimism from representatives of government, and utilities that peat development could occur in the Upper Peninsula. The peat resource is available, and there exists a need to create a greater economic base in this region. 


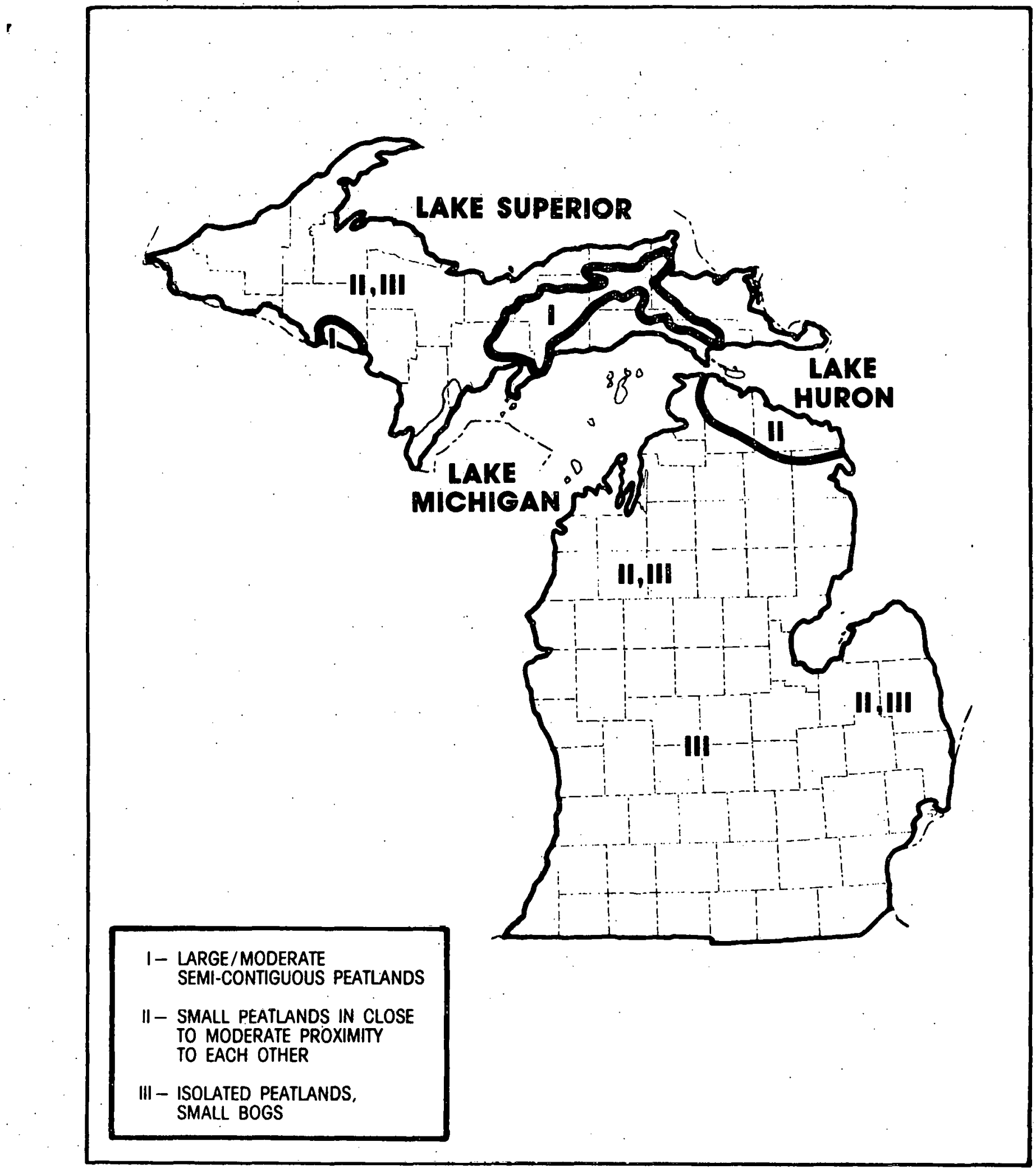

Figure 4-4 Michigan Peat Resource Areas 
After the completion of the Upper Peninsula peat resource inventory, the potential peat development options will be reviewed by the state. It has been recognized by the State DNR that the development of the Upper Peninsula for intrastate energy export to the Lower Peninsula may lead to controversy over wilderness preservation and development.

As indicated in Table 4.4, Michigan is very aware of the sensitive issues of development in wetlands and in the coastal zone and is especially concerned about air and water resource protection. The large agricultural and horticulture peat harvesting industry currently operating within the state has been affected by the enactment of strict envirnnmental regulations. State laws do not specifically forbid peat harvesting, but they do control offsite impacts such as discharge of water. The energy use of peat would be expected to come under the same scrutiny. 
Table 4.4 Michigan Peat Development Factors

(page 1 of 3 )

PEAT RESOURCES

Largest peat resources are found in the Upper Peninsula.

Current estimates of peatland suitable for fuel are significantly less than the older published resource estimates.

Michigan is the largest horticultural peat producer in the United States.

A limited survey of Michigan peat has been begun by Michigan Technological University for the U.S. DOE through the Michigan Energy Resource Research Association (MERRA).

\section{ENERGY DEVELOPMENT ATTITUDES}

The state is currently conducting a peat resource inventory jointly funded with DOE.

The U.S. Forest Service administers land with significant peat deposits on the Upper Peninsula but has not shown interest in development at this time because of availability of peat in the state and private sectors.

A11 gas and electrical production could be intrastate.

The interstate shipment of SNG out of Michigan may be politically sensitive.

The Detroit Edison Utility Company conducted a brief peat utilization study and concluded that peat utilization does have potential for utilities in the Upper Peninsula and the northern Lower Peninsula. 
Table 4.4 Michigan Peat Development Factors

(page 2 of 3 )

The Department of Natural Resources has indicated and understanding of the potential conflict between peatland development and wetlands preservation for fish and wildlife protection.

A gas pipeline through the Upper Peninsula could either discourage peat energy development or encourage peat-derived SNG development, depending on the mood of the state residents.

\section{ENVIRONMENTAL CONCERNS}

Even though there is no Wetlands Protection legislation, the Inland Stream Act (Public Act 346) effectively controls what. can be done to wetlands.

Peat development on the Upper Peninsula could come under the Michigan's Coastal Zone Management Program.

Michigan wetlands legislation, which is presently being considered, may affect peat energy development.

Social issues may be the greatest barrier to Upper Peninsula peat harvesting, especially because of recreation, wildlife, and forestry concerns.

Turbidity and acidity are major concerns associated with water discharge from a peat bog. Acid rain or snow is already a concern. 
Table 4.4 Michigan Peat Development Factors

(page 3 of 3 )

\section{ALTERNAT IVE ENERGY PROGRAMS}

$0 i 1$ exploration in the Pegion River has been curtailed to protect the elk and its habitat.

Within Michigan, peat development could potentially compete with wood-energy use.

For the development of a 20. MW wood-fired power plant, a 20 to 25 year payback period was required. The plant will start operating in Henry, Michigan.

$90 \%$ of Michigan's energy is imported.

\section{OTHER FACTORS}

The state is promoting economic development within the Upper Peninsula.

Present Michigan laws can be used to regulate drainage of wetlands.

No reclamation law exists for peat; however, DNR will not issue permits if suitable reclamation is not guaranteed. 


\subsection{NEW YORK}

\subsubsection{Resources}

Discrete peat deposits are located throughout the lowlands and uplands of New York State. The types of deposits found within the state are upland depression bogs, built-up deposits, and composite. The upland depression bogs are numerous and generally 10-100 acres in extent, with depths ranging from 5 to 15 feet.(20)

Within the state, the larger lowland deposits are principally found along the Lake Ontario Plain between the cities of Buffalo and Syracuse, as shown on Figure 4-5. The three largest deposits within this region are 0ak Orchards Swamp (10 square miles), Montezuma Swamp (10 square miles), and Cicero Swamp $(5,120$ acres $)$. Each of these areas is currently being used as a wildlife refuge. (81)

Many of the peatlands in New York have been developed for muck farming or cleared for pasture. The largest muck farms are found in the valley bottoms associated with the Fingerlakes region and in the lowland troughs adjacent to the Hudson valley. Recent studies have indicated that the area with the most potential for peat energy development is the Ontario Plain between Lake Ontario and the Adirondack Uplarids.

Much of the New York peat resource was lost during the colonial period, when the upper two feet were burned for clearing operations. The general rate of deposition within the area has been estimated to be 1 foot per 500 to 1,200 years. (20)

\subsubsection{Attitudes and Concerns}

The known peat resources of New York State are in isolated depressions and large lowlands. Several of these peatlands would be required for a single moderatescale plant. Known peatlands that could potentially support this scale of development are currently being used for agriculture and wildlife refuges and are available for development. The state is currently revising its peat resource 


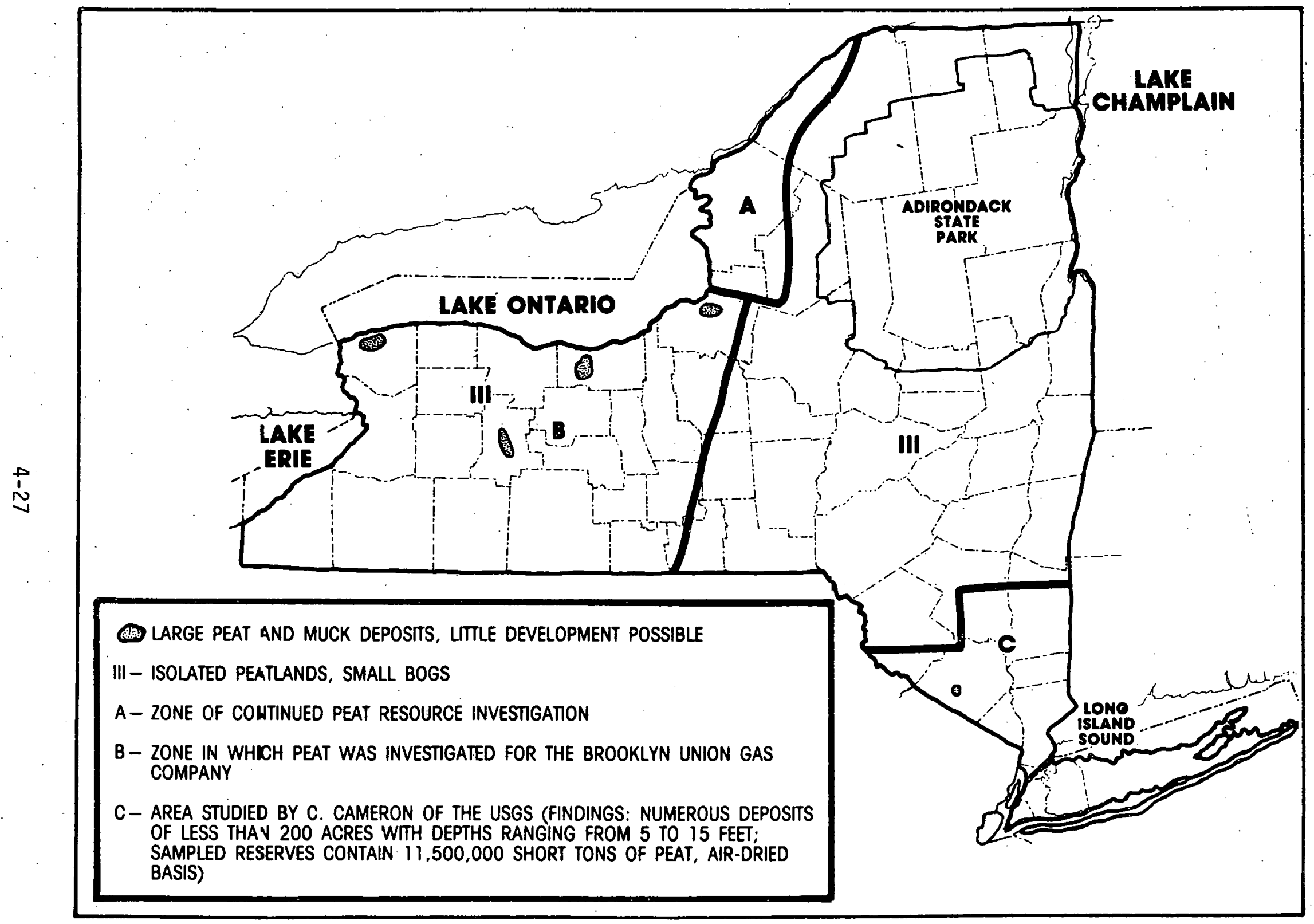

Figure 4-5 New York Peat Resource Areas 
estimates, however. The development of a peat harvesting facility might be regulated by the states surface mining laws which require an EIS and a site reclamation plan prior to development. 
TABLE 4.5 New York Peat Development Factors

(page 1 of 2)

\section{PEAT RESOURCES}

The peat resources in New York State (generally less than 400 acres and isolated) could not support large scale development; however, small-sized development could potentially occur.

Most of the peat resources are found along the Lake Ontario Plain.

Studies conducted by the USGS in the SW counties of the state indicated that peat bogs are generally 10 to 200 acres with depths varying from 5 to 20 feet.

The most significant peatlands are currently used for agricultural or wildlife refuges.

\section{ENERGY DEVELOPMENT ATTITUDES}

The limited size of the isolated peat resources affects the potential for harvesting numerous private or public peatlands.

The State. is currently reassessing peat resources to determine potential for development.

\section{ENVIRONMENTAL CONCERNS}

The development of major peatlands along the southern shore of Lake Ontario will be affected by land protected for wildlife. 
Table 4:5 New York Peat Development Factors

(page 2 of 2 )

Upper New York is iconsidered the recreational area of the state; and development would have to counter strong state interest in maintaining low levels of development in this area.

The state has a very strong wetlands protection law that requires permits for all actions affecting wetlands.

The state has a strip mining act that requires thorough local and state EIS review.

\section{ALTERNATIVE ENERGY PROGRAMS}

Brooklyn Union Gas Company prepared a brief feasibility study of the potential of peat utilization for SNG production.

The state is committed to all forms of existing fuels to supply large power requirements:

\section{OTHER FACTORS}

Several universities in the state are investigating peat resources for a number of different uses. 


\subsection{MAINE}

\subsubsection{Resources}

Although the individual deposits do not in themselves constitute a major source of energy, several peat bogs could supply a small to moderate energy source. The state has estimated that the peatlands comprise about 0.77 million acres and is currently conducting a comprehensive statewide peat resource analysis to quantify the actual resource available. Peatlands are located throughout the state as shown in Figure 4-6. (107).

Maine peatlands are comprised of confined primary mires as defined by Radforth. Cameron's work in NE Maine has shown that the deposits are composed of five different types. These are: 1) valleys occupied by streams; 2) closed basins; 3) plateau domes; 4) domes and secondary ponds; and 5) coalesced domes. The discrete deposits are generally less than several hundred acres; however, deposits in excess of 1,000 acres do occur throughout the state. One large bog in eastern Washington County has a maximum depth of 20 feet, covers 4,000 acres, and contains an estimated $8,000,000$ short tons of peat. (22)

\subsubsection{Attitudes and Concerns}

The State of Maine is currently conducting a peat resource inventory and reviewing the options for energy development. From these studies, it is anticipated that a definitive peat development program for small-and moderate-scale facilities will be developed. The state dependence on fuel oil and the readily available peat resources have tended to encourage this development program. The use of multiple bogs over the life of a moderate size facility would require careful facility sitings and the establishment of an offsite transportation network.

The state is reviewing technological options for direct heat, electrical, SNG, and liquids production. All of these proposals may have some applicability 


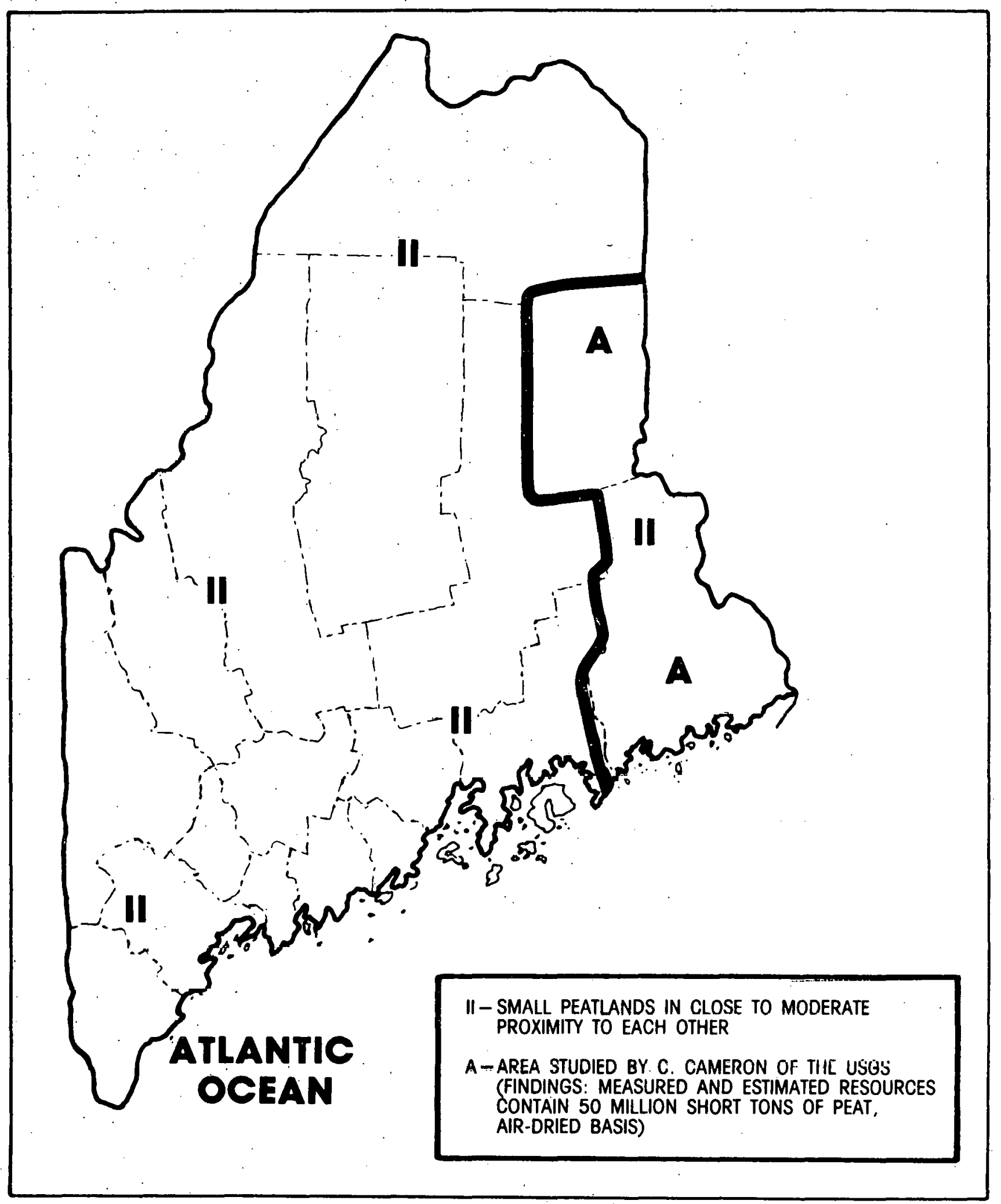

Figure 4-6 Maine Peat Resource Areas 
across the state; however; it is felt that the principal peat utilization mode would be for small-to-moderate-sized electrical power and cogeneration facilities. The principal reasons for such development would be the inplace electrical power grid, existence of several electrical companies, and the general lack of statewide gas transmission facilities. A summary of the factors that will affect the peat development are shown in Table 4-6.

The existence of numerous scattered wetlands, peatlands, and lakes within the state reduces the individual uniqueness of a particular peatland. Consequently, within this type of environment, the public and private environmental pressure to preserve each individual bog may not be great.

The state is cognizant of the resource allocations that will be committed for a project and is establishing a steering committee composed of public and private groups that will aid in forming peat development policies. 
Table 4.6 Maine Peat Development Factors

(page 1 of 3 )

\section{PEAT RESOURCES}

Peat resources in Maine are depressed bogs of from 10 to 3,000 acres; most are in the range of 10 to 400 acres.

In general, no one area would support a large- or moderate-scale energy facility; several bogs would be needed.

The state and USGS, with the financial and management support of DOE, are currently reviewing the peat resources.

The peat resources are generally well distributed throughout the state.

\section{ENERGY DEVELOPMENT ATTITUDES}

The state energy program is seriously reviewing peat development for small-scale steam and electrical uses. The facility options being reviewed are for low, moderate, or high Btu.

The development of new energy sources would most likely be for local industrial and residential customers.

The state energy office is interested in peat-to-methanol liquids production.

A state committee composed of industrial, government, environmental, political, and private interests is being formed to study peat as an energy source; it will act as a state steering committee.

Although the state has not adopted a definitive peat policy, it currently has the legal mechanisms to review any peat project that is brought before it. 


\section{Table 4.6 Maine Peat Development Factors \\ (page 2 of 3 )}

\section{ENVIRONMENTAL CONCERNS}

Because there are many wetlands, the state wildlife policies do not appear to restrict development of peatlands on a controlled basis.

Peatlands are generally not within the coastal zone management area.

Unsettled Indian claims within the state could cause land use problems.

Most of the peatlands are located on unorganized lands for which there are no current definitive land use plans.

\section{ALTERNATIVE ENERGY PROGRAMS}

Gas distribution systems within the state are not well developed.

The Tapeco LNG project may bring gas into Maine and promote a wider distribution system.

Maine has no competing oil, gas, or coal production facilities and is dependent upon imported coal, LPG, and oil at this time; offshore and overthrust gas and oil exploration may change this situation.

The use of peat for a source of energy would compete to some degree with wood and bark power alternatives.

OTHER FACTORS

Horticultural peats could be used for soil amelioration in potato-growing counties. 


\section{Table 4.6 Maine Peat Development. Factors (page 3 of 3 )}

Most of the peatlands in northern Maine are owned by the large timber and paper companies.

Multiple small scale and moderate scale developments are possible within the state. 


\subsection{NORTH CAROLINA}

\subsubsection{Resources}

The major peatlands in North Carolina, as shown in Figure 4-7, occupy the coastal plain between the Suffolk Scarp and the bay coastline. The widely distributed organic soils have been derived from the accumulation of organic litter grown within a freshwater environment. Pollen studies indicate the accumulation started approximately 9,000 years ago and has proceeded at variable rates, principally controlled by the fluctuation of sea level elevations and climatic variations. The peat complexes along the Atlantic and Gulf coasts are not associated with the moss and sedge complexes of the northern U.S. and Canada. Instead, the organic materials have been derived from trees, shrubs, and other herbaceous materials associated with a coastal marsh and woodland complex. Organic soil depths within the area can reach a depth of 12 feet but generally range from two to six feet. (43)

The North Carolina peats, which are highly decomposed, have a caloric value from 7,000 to 10,000 Btu per pound, with low ash and sulfur content. The current development plan of the First Colony Farms, a private corporation, is to construct a large-scale peat harvesting system to supply a 150 megawatt electrical complex. In response to this proposed scheme, the State of North Carolina is conducting studies to determine the environinental consequences of development. (109)

\subsubsection{Attitudes and Concerns}

With the first company in the country actively pursuing a program to develop its peat resources for energy and agricultural purposes, North Carolina has a unique opportunity to identify and solve environmental problems. Ihe decision by the state will provide a landmark determination for the development of peat along the Atlantic and Gulf coasts. First Colony Farms has conducted the necessary technical and economic analyses t.j the point where it believes it possesses the necessary technologies to develop a feasible medium-scale peat energy project from peatlands it. owns. 


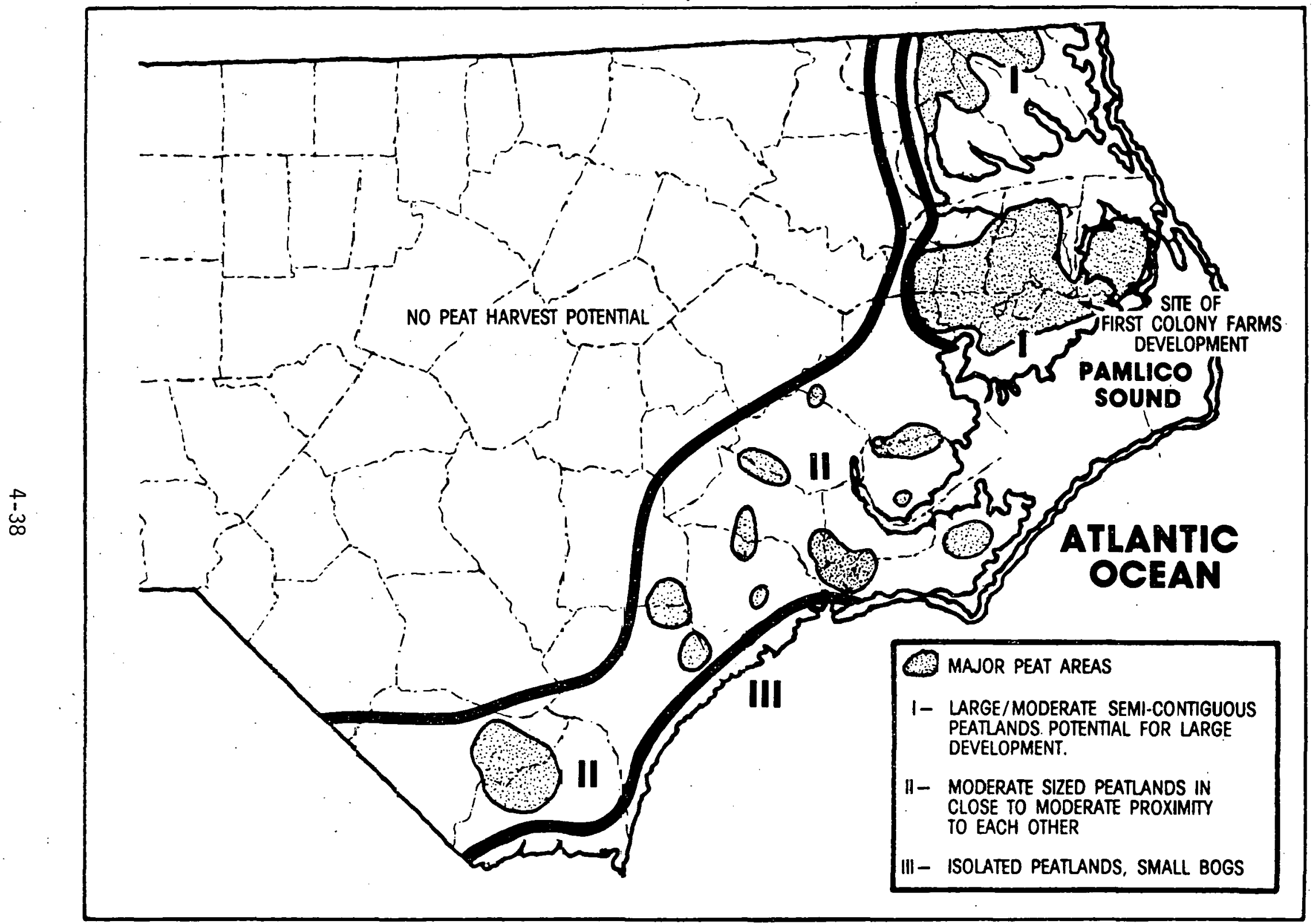

Figure 4-7 Vorth Carolina Peat Resource Areas 
Recently, the state of North Carolina has requested that First Colony Farms prepare an environmental impact assessment (EIA) on the development. The state is concerned over the potential impacts that the large-scale drainage will have on the Ablemarle-Pamlico Sound and estuaries. Table 4.7 summarizes the factors affecting development of peat in North Carolina. 
Table 4.7 North Carolina Peat Development Factors

(page 1 of 2)

\section{PEAT RESOURCES}

The coastal peat resources are extensive and have favorable fuel grade qualities.

Most peatlands are in private ownership.

There is extensive use of peatlands for agriculture and forests.

\section{ENERGY DEVELOPMENT ATTITUDES}

A private corporation (First Colony Farms) is planning the use of its peat resource to fuel a 150 megawatt electrical power plant and is also developing alternative peat fuels.

The state's rural electrical cooperatives are advocates of the First Colony Farms project.

\section{ENVIRONMENTAL CONCERNS}

Most peat resource development will fall within the Coastal Zone Management Program once a program is developed.

Saltwater intrusion and estuarine impacts have already been noted from large scale coastal agriculture development.

The state Department of Natural Resources has requested that First Colony Farms prepare an EIA for further peatland energy development. 
Table 4.7 North Carolina Peat Development Factors

(page 2 of 2 )

Wetlands, surface, and groundwater protection programs are very strong within the state.

The potential environmental impacts on the estuarine ecosystems are considered to be a prime environmental issue. 


\subsubsection{Resources}

The South Carolina peat resources, with boundaries as shown in Figure 4-8, are found principally within the coastal plain wetlands. The South Carolina coastal wetlands encompass approximately 682,000 acres, of which 75,000 acres have been defined as peatlands. Large peat deposits that could be harvested are also associated with the pocosin wetlands. A pocosin is a specific type of wetland that, through its morphological development, has formed a thick peat horizon. These areas are characterized by shrubs, small evergreens, and thorny vines that form impenetrable thickets. The state is currently assessing its peat resources through the DOE-state program. (110)

\subsubsection{Attitudes and Concerns}

The coastal wetland areas support large stands of overgrowth and provide unique habitats within the state. The use of these resources will require a review under the South Carolina's coastal zone management program, as indicated in Table 4.8. Under this program, harvesting, siting, and potential secondary development factors require evaluation for protection of the coastal areas. The clearing of large wetlands will be of concern to environmental groups who want to protect the coastal areas for their intrinsic recreational and environmental values. These areas have experienced little industrial or energy-related development, except for logging. Land ownership along the coastal areas is predominantly private and controlied by major timber and paper companies. $(99,110)$

Estuarine areas support an extremely rich habitat and moderate-sized commercial fishing industry. The protection of these resources is of prime concern; any development would receive extensive review by local interests. 


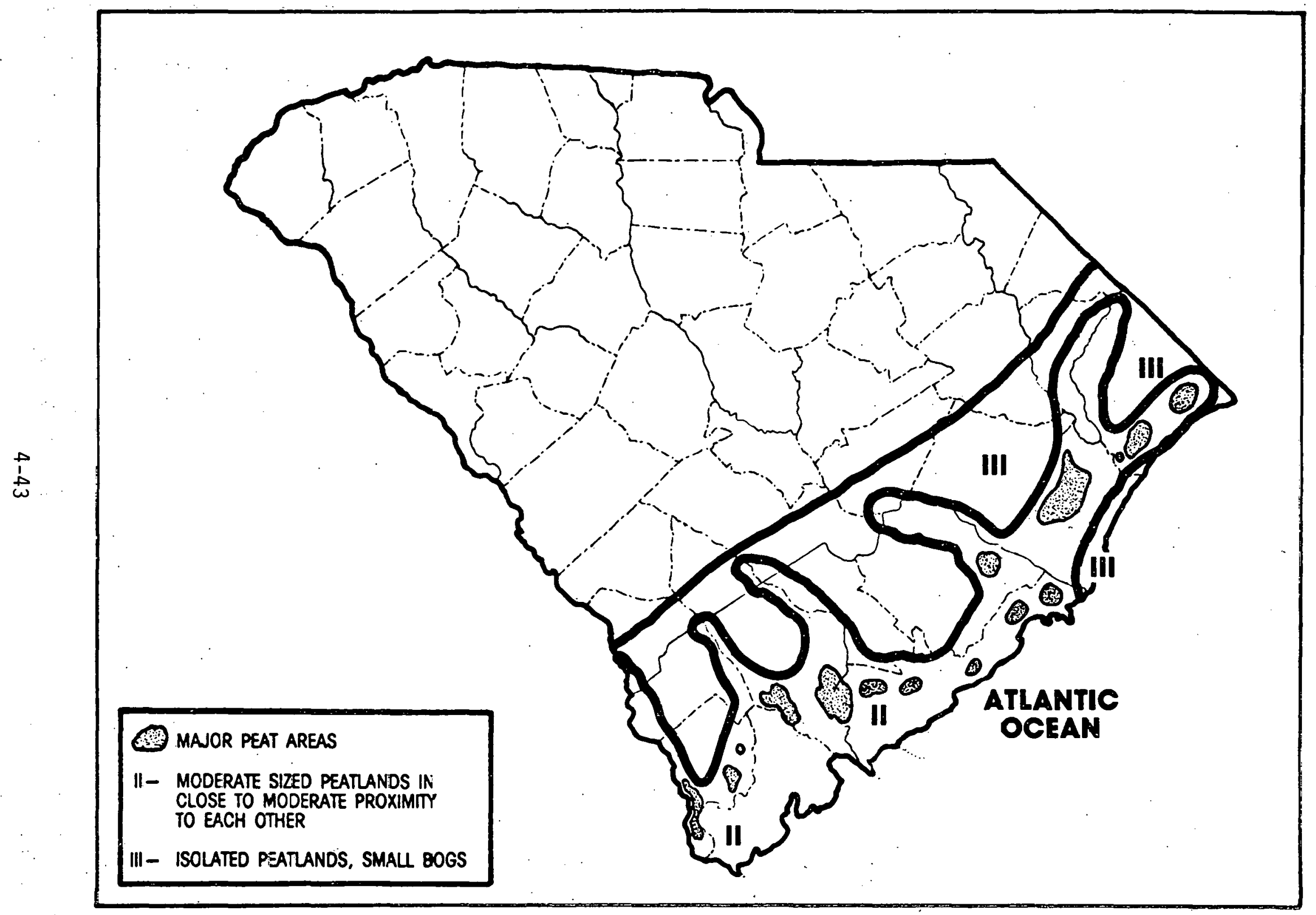

Figure 4-8 South Carolina Peat Resource Areas 
Table 4.8 South Carolina Peat Development Factors

(page 1 of 2 )

\section{PEAT RESOURCES}

Coastal counties incorporate most peatlands and are covered by a comprehensive state Coastal Zone Management plan.

Most peatlands are in private ownership.

Drainage of the areas for milled- or sod-peat production may be difficult.

Very little information is known concerning the quality, quantity, and location of the state's peat resources.

State is currently conducting DOE-sponsored resource analys is.

Little peat harvesting is currently conducted within the state.

\section{ENERGY DEVELOPMENT ATTITUDES}

The development and management of the South Carolina coast for natural recreational areas could be in conflict with peat resource development.

Peatland development would come under the policy decisions of the Coastal Zone Management Program and Coastal Council.

The state is currently developing an energy policy, but peat will not be incorporated until a full àsessiment is made. 
Table 4.8 South Carolina Peat Development Factors (page 2 of 2)

\section{ENVIRONMENTAL CONCERNS}

Any peatland development in the coastal counties will require a review by the state Coastal Zone Management Agency.

Coastal erosion and saltwater intrusion have the public concerned over future coastal devel opment.

Pocosins provide habitat for a number of endangered and threatened species.

\section{ALTERNATE ENERGY PROGRAMS}

Currently, there is little coastal energy production or industrial development.

\section{OTHER FACTORS}

A large majority of the peatlands are overlain by wetland forests that have value for logging.

Current legislation is considered sufficient to handle peat harvesting operations. 


\subsection{FLORIDA}

\subsubsection{Resources}

Peat and organic soils cover significant areas of the State of Florida. The extent of the true peat (as distinguished from the other highly organic soils) is approximately three million of the state's 34.6 million acres. The major peat area, as shown in Figure 4-9, consists of the, southern Everglades south of Lake Okeechobee. This subtropical mire complex contains extensive agricultural areas, unmanaged lands, and the Everglades National Park. (75) Southern Florida is extremely flat and slopes to the south with a gradient of less than two feet per mile. Water through the peatland channels travels at approximately one-half mile per day. The peatlands form a surface aquifer that is important to the water budget of the Everglades National Park. (111)

\subsubsection{Attitudes and Concerns}

Peatlands in Florida have been used extensively for agricultural purposes, and this pattern is not expected to change. Draining of peatlands and use for agriculture has resulted in significant subsidence of the land, principally through oxidation of the upper layers. As a consequence, there has been a net reduction in agricultural productivity and a need established for additinnal agricultural lands in the future. There is some state-wide concern over maintenance of the agricultural resource, the state's principal industry. Competing uses such as energy must necessarily be placed in perspective.

The peat deposits within Florida are the principal surface aquifer within the state, and any large scale disruptions of this resource could have serious effects on receiving areas. Decrease in surface water flow could alter sensitive ecosystems, lead to subsidence of the peat mat, and cause greater salt water intrusion problems. Extensive agricultural development in Dade County has also lead to the eutrophication of numerous lakes, loss of organic soil, and reduction in the water table. State resource agencies are concerned with further development within the peatlands. This concern has led to the denial of several large 


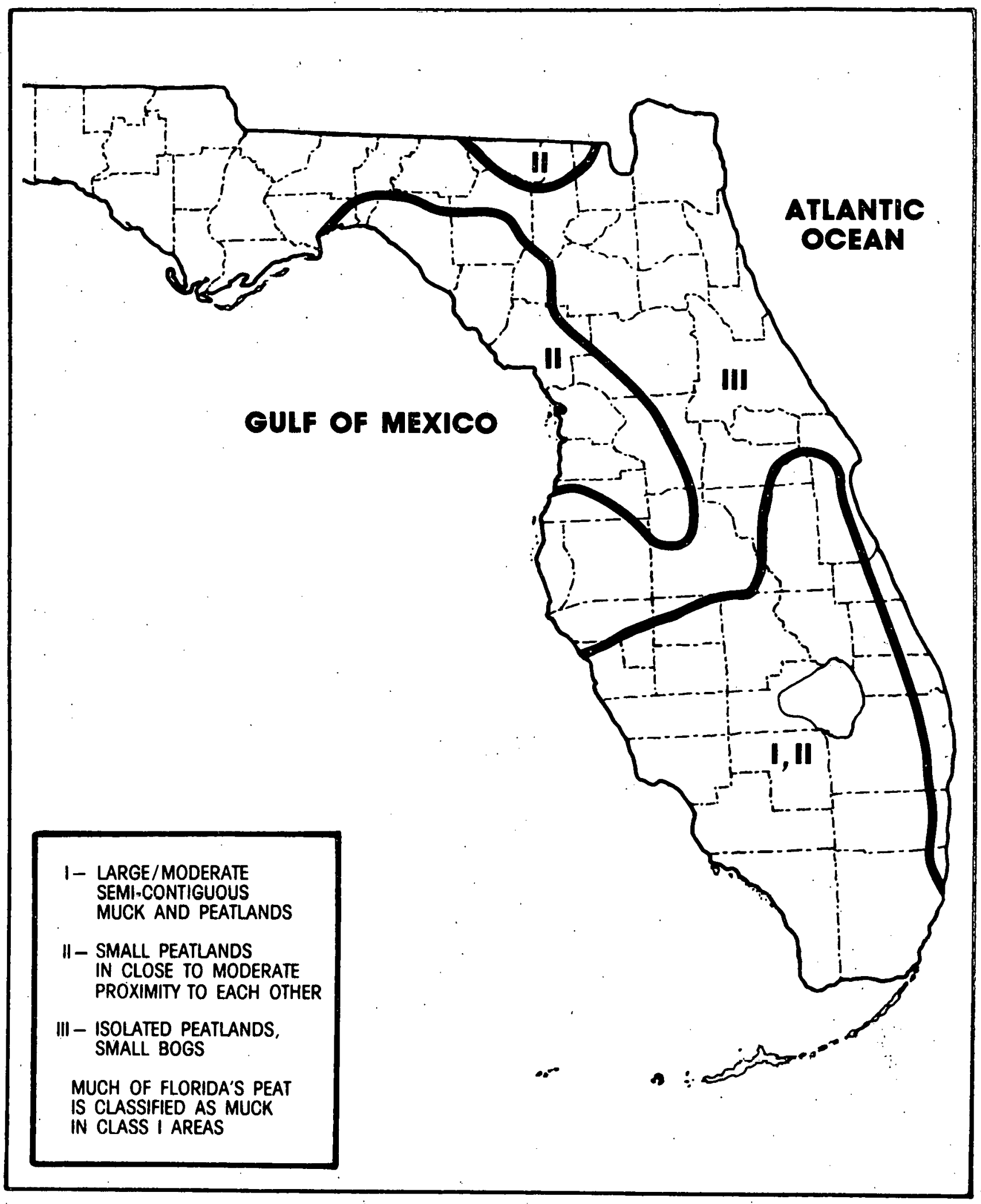

Figure 4-9 Florida Peat Resource Areas 
civil projects and must be resolved prior to large-scale peat development within the state.(111) The peat resources within the southern portion of the state could support a large-scale peat facility; however, the development of such a project could be expected to have a significant impact on the Everglades and other areas downslope of the project.

Table 4.9. summarizes the factors concerning peat development in Florida. 
Table 4.9 Florida Peat Development Factors

(page 1 of 3 )

\section{PEAT RESOURCES}

Extensive peatlands are located throughout the state.

A comprehensive peat survey was conducted by Davis in the 1940's. (112)

$$
\text { ENERGY DEVEL OPMENT ATTITUDES }
$$

The state has very strong energy siting regulations that require consideration of regional impacts on water resources and wetlands.

The large agricultural industry within the state would be expected to promote increased agricultural production from any new lands that are allowed to be developed.

There is no regulation against the use of peat as a fuel.

\section{ENVIRONMENTAL CONCERNS}

Significant subsidence of the land has occurred with reduction in water levels.

The entire state will be governed by the state Coastal Zone Management. Program when it is completed.

Surface and ground water problems are acute.

Salt water intrusions within the state have become a major issue.

Certain peatlands would be expected to provide habitat for many endangered and threatened species. 
Table 4.9 Florida Peat Development Factors (page 2 of 3 )

Drained peatland areas in Florida are losing depths of one inch per year from peat oxidation and wind and water erosion.

Eutrophication of lakes has occurred as a result of wetland drainage, canals, river dredging, and agricultural runoff.

Federal agencies and environmental groups have offered strong resistance to further development of the state's wetldruls arid would actively oppose the large-scale harvesting of peat.

Large-scale developments, such as the Cross Florida Barge canal and the Miami Jet Airport, have been stopped as a result of the public interest and adverse impact on the delicate ecosystems and hydrology of the peninsula. In general, there is a resistence to large-scale projects involving wetlands.

\section{ALTERNATIVE ENERGY PROGRAMS}

The state has oil and gas production facilities and has nuclear power generation.

Florida is promoting renewable energy resources such as Woodex, a process using wood scraps made into pelletized form for use as a boiler fuel.

\section{OTIILR FACTORS}

large acreage of peatlands have already been drained for agriculture and land development. 
Table 4.9 Florida Peat Development Factors

(page 3 of 3 )

Agriculture in Florida is less energy intensive than in other states because of the high quality of rich muck soil - less fertilizer and equipment operation are necessary per unit of production.

A. 1972 bond issue was passed in Florida to provide funds for purchase by the state of environmentally endangered wetlands. To date, over $\$ 200$ million has been spent to purchase and maintain wetlands. 


\subsection{LOUISIANA}

\subsubsection{Resources}

The extent of the peat within the southern Louisiana Coastal Plain has not been well studied. The 1967 Soil Conservation Study indicated that 1.8 million acres could be considered as potential peatlands. This acreage represents approximately six percent of the land within the state. The majority of the peat (shown in Figure 4-10) is confined to the low lying coastal wetlands, the Mississippi Delta area, and the Atchafalaya Floodway. Two general peatland types exist within the state. These are the forested waterways draining the low lying coastal areas and the coastal brackish and saltwater marshes found north and south of the intracoastal water and along the lower Mississippi River Delta. The general slopes within the area are less than 1 foot per mile, and the majority of the peatlands are less than 10 feet above sea level. $(113,114,115)$

The coastal marsh complexes have experienced extensive development, such as roads, oil and gas exploration, drainage right-of-ways, rice farming, and ranching along the chenier ridges. Peat harvesting for horticultural and agricultural purposes is not a significant industry within the state. The quality of peat within the state is highly variable because the historic inundation of the peatlands from freshwater and hurricane flooding has resulted in the incorporation of sediments, clays, silts, and other organic debris with the peat. $(113,14,115)$ The Louisiana Geological Survey is currently conducting an initial peat resource survey.

\subsubsection{Attitudes and Concerns}

The Louisiana peat development factors are listed in Table 4.10. Louisiana, unlike any of the other states having peat, is accustomed to large energy development projects and has supported energy development as long as the benefits outweigh the risks. The peat resources within the state lie along the floodway, offshore, coastal, and delta areas. These areas constitute some of the most 


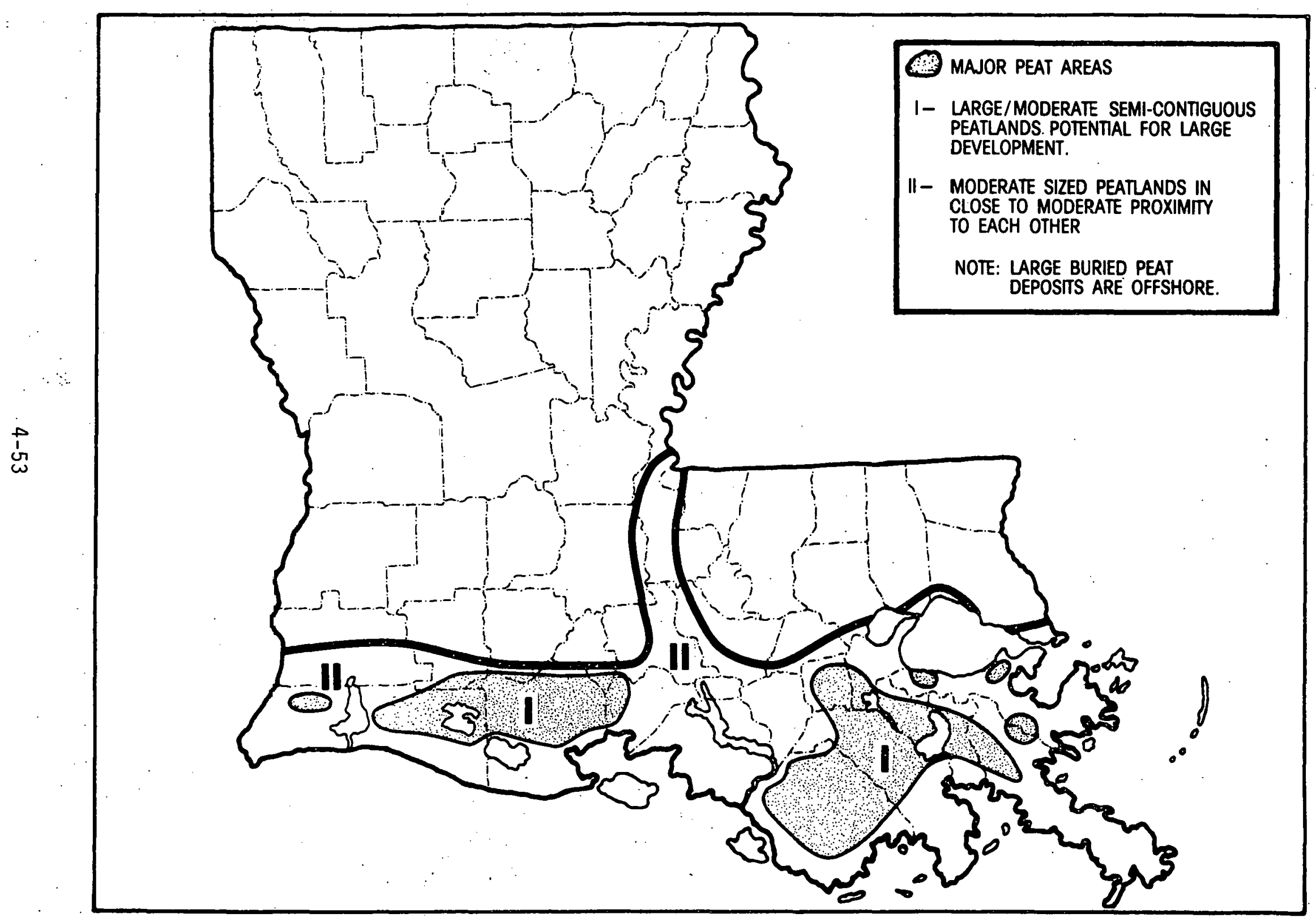

Figure 4-10 Louisiana Peat Resource Areas

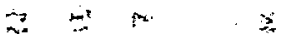


valuable and sensitive environmental areas within the state. (115) Energy development within these areas has been historically for oil and gas recovery, hydrocarbon storage, and transport corridors; no large surface exploitation has been conducted. Environmental problems related to current energy production have resulted from changing the surface water drainage patterns, salt water intrusion, dredging, subsidence, pollution discharges, and the elimination of valuable habitat. Similar environmental issues could occur as the result of peat harvesting. Because of the physical location of the peatlands and the climatic conditions, the only feasible harvesting methods may be hydraulic or direct extraction. The reclamation of lands used for peat extraction would be primarily for aquatic and estuarine habitat.

Wetlands protection in Louisiana is a very critical item because of the intrinsic value of the ecosystem and the commercial value derived from the fish and shellfish industry. Because of the inevitable loss of wetland habitat and the potential for producing offsite impacts, any moderate- to large-scale peat development program will encounter significant environmental opposition from the public unless extensive mitigation programs are developed to assure maintenance of the fish and shellfish resources. 
Table 4.10 Louisiana Peat Development Factors

(page 1 of 3 )

\section{P.EAT RESOURCES}

Majority of peatlands are located in the coastal floodway and delta areas.

Some peatlands in the state are at or near sea level elevation, severely limiting the potential for natural drainage.

Peat in coastal areas has high sediment and clay content, and, as a result, the fuel grade quality of the peat is highly variable.

Peat in swamp areas ranges in depth from 10 to 20 feet. Marsh peat areas range in depths from four to six feet.

Large currently unrecoverable peat deposits are buried offshore in the Gulf of Mexico.

\section{ENERGY DEVELOPMENT ATTITUDES}

The Louisiana Geological Survey has begun to review the state's peat resources and development options.

Rehabilitation and avoidance of marshlands by energy transportation corridors are critical issues in the state approval process.

No energy plan exists for Louisiana. (State officials feel there is sufficient planning to handle any development.) 
Table 4.10 Louisiana Peat Development. Factors

(page 2 of 3 )

A peat study is being undertaken by the Coastal Studies Institute of Louisiana State University (Baton Rouge), primarily to determine which areas are suitable for construction - this could be adapted to energy, since the study will investigate such things as liquid content, total organic content, decomposition state, hydrology; bog depth, heat value, etc.

\section{ENVIRONMENTAL CONCERNS}

A recent Federal court case in Louisiana involving the conversion of private forest wetland to drained agricultural land has dctermined thal lhe drainage required a NPDES permit under EPA and USF\&W wetlands regulations. Decisions such as this will affect future peat energy development in the state.

Wetlands and salt marsh protection is a critical item within the state.

Large tracts of peatlands are in or adjacent to state and national wildlife refuges.

Completion of the state Coastal Zone Management program will limit usage of peat in protected areas:

In situ dewatering techniques may not be feasible in many peatbogs in Louisiana because they are near or below sea level.

Maintenance of fish and shellfish industries is of prime importance.

\section{ALTERNATITE ENERGY PROGRAMS}

State is a net exporter of energy. 
Table 4.10 Louisiana Peat Development Factors

(page 3 of 3 )

State is currently interested in further exploitation of its oil, gas, geopressure, geothermal, and coal energy resources.

Eniergy sources are controlled by separate state agencies, each of which is concerned with a specific energy source, e.g., oil, gas, coal, etc.

\section{OTHER FACTORS}

The large amount of precipitation could preclude effective use of peat dry harvesting techniques.

Industry is interested in developing a commercial peat operation using hydraulic harvesting for agricultural purposes. 


\section{SECTION 5}

The DOE's peat energy research and development program includes the following four distinct aspects: peat energy technology, peat resource inventories, socioeconomic issues, and environmental issues. Of the four, the programmatic and site specific environmental analyses require the gathering of diverse and difficult to obtain data. The large geographical distribution of U.S. peat reserves, the heterogeneity of the affected ecosystems, and the diverse environmental impact potential for the various peat development options all contribute to this difficulty.

The proposed environmental data analyses and impact analys is program should principally rely on the joint participation of peat resource states for gathering preliminary state environmental data and Federal agencies for conducting specific programmatic environmental impact analyses. The environmental data collection and analys is effort described in Section 3. The resolution of these issues, including the development of environmental guidelines and impact mitigation measures, will culminate in the development of an Environmental Impact Analys is for the DOE Peat Development Program by the end of Phase III.

The objectives of Phase II of the DOE program include:

- Determination of the environmental feasibility of small, moderate, and large-scale peat energy development;

- Determination of the role of the DOE Peat Development Program in the U.S. energy program;

- Preparation of a data base for a programmatic assessment of the overall DOE Peat Development Program;

- Describing the environmental conditions of the U.S. peat reserves; 
- Definition of the major environmental variables controlling peat resource development;

- Development of Federal interagency agreements for generic environmental analyses of issues common to most sites;

- Coordination with interagency and interstate agreements on the collection of environmental data;

- Offering technical environmental analysis capabilities to interested pạrties; ạnd

- Elliciting peat development policy decisions from Federal and state agencies.

Each individual state program, contained within the overall peat environmental program, is designed to provide background environmental data and promote the formulation of peat development policies within the state. The Federal program is structures to provide basic environmental research through interagency agreements, to perform R\&D functions, and to define Federal wetlands policies and the role of peat in the national energy plan. The joint state/Federal Environmental programs, as illustrated in Figure 5.1 and discussed in Table 5.1, need to provide basic environmental data for Phase II programmatic environmental assessments and for the formulation of necesiary Federal/state peat energy development policies. In the future, the exteht and detail of on-site field activities will need to increase for each peat energy project as it progresses. However, for the Phase II environmental analyses described here, aerial reconnaissance; local contacts, and review of the published and unpublished data are more appropriate than conducting extensive and expensive detailed field surveys. Due to the size and heterogeneity of peat resources, extensive field surveys should not take place until definitive sites have been selected for development; the financial burden of conducting these field programs will fall to the peat energy developer. 
PHASE I:
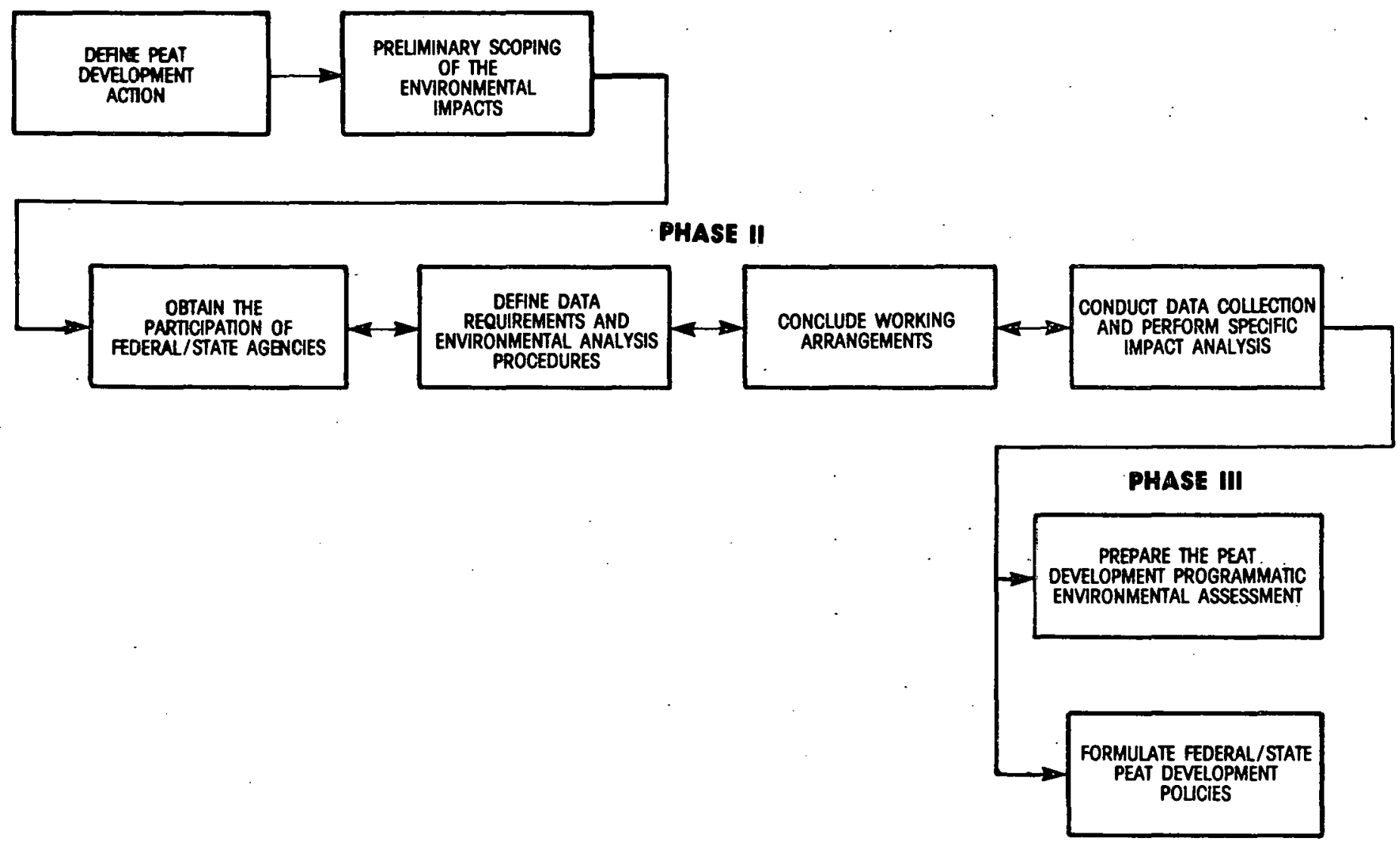

FIGURE 5.1. WORK ELEMENTS. OF THE-PEAT DEVELOPMENT ENVIRONMENTAL PROGRAM 
PHASED

WORK ELEMENTS

Define Peat

Development

Action

Preliminary

Scoping of

the Environ-

$\stackrel{u}{t}$

mental Issues

Obtain the

Participation

of the State

and Federal

Agencies
RESPONSIBLE AGENCIES

AND AGENTS

DOE

Private Contractors

DOE

Private Contractors

DOE, Federal Agencies involved in environmental research and land management. Individual State Agencies
Define the objectives of the ?eat

Development Program. Define

the engineering options which are available to obtain these goals.

Conduct preliminary R\&D activities.

Fund preliminary environmental studies.

Analyze the initial development

options and scope the envirannental

issues.

Conduct a preliminary environnental analysis of the national peatiands.

Elicit initial response from the interested state/federal agen $=i$ es to help devel op a peat resear $\mathrm{ch}$ development program.

\section{PRODUCTS}

Publish technical evaluations environmental issue publications, state of the art information.

Publish a preliminary environmental scoping document, Define major, moderate, and minor impacts for the given development options.

Obtain preliminary understanding to participate in a study.

Determine necessary funding arrangements.

TABLE 5.1

WORK ELEMENTS OF THE PEAT DEVELOPMENT ENVIFONMENTAL PROGRAM 
PHASED

WORK ELEMENTS

Define data

requirements

DOE

and Environ-

mental Analysis

Procedures

Conclude working DOE

arrangements,

Federal Agencies

ir agreements

Federal Agencies

State Agencies

State Agencies

AND AGENTS
Private Contractors

DOE

Conduct data

collection and

Federal Agencies

individual pro-

grammat ic

analyses

OBJECTIVES

PRODUCTS

Bring interested parties to a forum to discuss the study plans and

requirements.

Establish a forum for initial policy development views on development.

Define more detailed environmental scoping.

Establish agency workscopes and protected work efforts.

Define monetary requirements.

Coordinate field and programmatic modelling efforts to gather material data requirements. Ensure data collection is proceding per the workscope tasks.
Clear understanding of agency viewpoints on development, more definitive environmental scoping.

Discussions of agency legislative controls.

Establish agency workscopes.

Sign Interagency Agreements and assign grant money to the states.

Prepare a concise data description and analysis for the programmatic EIS.

Prepare more indepth data collection and analys is for the state and agency policy management. 


\begin{tabular}{|c|c|}
\hline $\begin{array}{l}\text { PHASED } \\
\text { WORK ELEMENTS } \\
\end{array}$ & $\begin{array}{c}\text { RESPONSIBL: AGENCIES } \\
\text { AND AGENTS } \\
\end{array}$ \\
\hline Prepare the Peat. & DOE \\
\hline $\begin{array}{l}\text { Devel opment } \\
\text { Programmatic } \\
\text { Environment al } \\
\text { Assessment }\end{array}$ & Private Contractors \\
\hline $\begin{array}{l}\text { Formulate Peat } \\
\text { Development }\end{array}$ & $\begin{array}{l}\text { Federal/State Land } \\
\text { Managers }\end{array}$ \\
\hline Policies & $\begin{array}{l}\text { Agencies with Permit } \\
\text { Review Powers over } \\
\text { Wetlands }\end{array}$ \\
\hline
\end{tabular}

Assimilate the concise state write-ups and programmatic studies into a programmatic assessment - coordina:e the external environmental studies into the document.

Define under what conditions peat energy development can proceed.
Draft programmatic environmental assessment.

Specific Federal/State policies and guidelines concerning peat development. 
The environmental workscopes for the participants are comprised of researching the environmental issues as defined in Section 3, and Appendix A, and conducting the broad environmental surveys necessary to support these analyses. The environmental parameters which would be incorporated into the environmental surveys and issue analysis are listed in Table 5.2. It is estimated that both Federal and state environmental studies could be conducted within a one-two year period.

As indicated in Table 5.2, the parameters 1 isted for the environmental survey do not coincide exactly with the environmental issues discussed in chapter 3. This difference is due to the fact that the field surveys comprise the basic elements from which environmental analyses are conducted. For example, determining if rate and endangered species will be impacted can only be resolved after an analysis is conducted on each botanical, wildlife, and aquatic rare and endangered species.

A good determination can be made based on available data and local contacts as to the likelihood of such a problem. Based on this subsequent decisions can be regarding detailed field surveys.

A major consideration for the preparation of any generic environmental assessment, is the need for uniform state environmental data. Under this program, the data provided to DOE should provide the concise environmental resource information required for programmatic analyses and not a detailed site specific analyses. The data, should be surficiently complete to allow the states to establish the environmental quality and values of their peat resource areas and to provide a basis for formulating state development policies. After the uniform reporting is provided provisions can be made to preparing more detailed special reports based on states special environnmental conditions.

The functional field work eleilierils, as listed in Table 5.2 , have been divided into six major functional work groups: Air, Terrestrial-Botanical, TerrestrialWildlife, Water Resource, Aquatic, and Socioeconomic Environments. Socioeconomic work elements are fully discussed within the DOE Radian Peat Report and are 
TABLE 5.2

FIELD ENVIRONMENTAL STUDIES FOR PEAT RESOURCE DEVELOPMENT

FUNCTIONAL ENVIRONMENTAL

DATA REQUIREMENTS

\section{INITIAL LIMITED} ONSITE SURVEYS

\section{LOCAL CONTACTS \\ AERIAL/PHOTO \\ RECONNAISSANCE}

STATE CONTACTS

AND DATA BASES

PUBLISHED REPORTS

\section{AIR ENVIRONMENTAL AND QUALI'YY ANALYSIS}

$\mathrm{CO}$

$\mathrm{SO} X$

NSPX

Ozone

Air Pollution - Climatic Variables

Peat Harvesting - Climatic Variables

Noise

TERRESTRIAL ENVIRINMENTAL ANALYSIS

BOTANICAL ANALYSIS

Timber Value

Rare and Enciangered Species

Community \& Habitats

Wildlife Valles Focd/Habitat

Reregivation Potential

Habitat, Uni=ueness

Preservation Potential

Future Orgaric Use Potential

Recreational Potential

Pext Types

Stump and Wood Residuals

Net Productivity

Wetland Classification

$x$
$x$
$x$
$x$
$x$
$x$

$x$
$x$
$x$
$x$
$x$

$x$
$x$
$x$
$x$
$x$
$x$
$x$
$x$

$$
\begin{aligned}
& x \\
& x \\
& x \\
& x \\
& x \\
& x \\
& x \\
& x \\
& x \\
& x
\end{aligned}
$$

$X$

$x$

$x$

$x$

$x$

$x$

$x$

$x$

$X$

$x$

$x$ 
TABLE 5.2 (Cont'd)

FIELD -ENVIRONMENTAL STUDIES FOR PEAT RESOURCE DEVELOPMENT

FUNCTIONAL ENVIRONMENTAL

DATA REQUIREMENTS

\section{INITIAL LIMITED \\ ONSITE SURVEYS}

GEOLOGY/SOILS

WILDLIFE ANALYS:-S

Large Mammal Habitat Value Small Mammal Habitat Value Avian Habitat Value

Rare and Endangered Species Current Heating Usage

Unique Ecosystems

Migrating Hildlife Values

Wildlife Reclamation Values

Breeding and Feeding Areas

Habitat Survival

Species Diversity

Commercial and Recreational

Wildlife Values

Net Productivity

\section{WATER RESOURCE ANALYSIS}

Water Quality Parameters

Hydrology Surface/Groundwater

Downstream Water Users

Drainage Patterns

Contributing Areas

Groundwater Environment

Flood Prone Areas

Saltwater Intrusion

\section{$X$}

LOCAL CONTACTS

$x$

AERIAL/PHOTO

RECONNAISSANCE

$x$

CONTACTS

AND DATA BASES,

PUBLISHED REPORTS

$x$

$\begin{array}{ll}x & x \\ x & x \\ x & x \\ x & x \\ x & x \\ x & x \\ & x \\ x & x \\ x & x \\ x & x \\ x & x \\ x & x \\ x & x\end{array}$

$x$

$x$

$x$

$x$

$x$

$x$

$x$

$X$

$x$
$x$
$x$
$x$
$x$
$x$
$x$
$x$
$x$
$x$
$x$
$x$
$x$
$x$

$\begin{array}{ll}x & x \\ x & x \\ x & x \\ x & x \\ x & x \\ x & x \\ x & x \\ & x\end{array}$

$x$
$x$
$x$
$x$
$x$
$x$
$x$
$x$
$x$
$x$
$x$


TABLE 5.2 (Cont'd)

FIELD ENVIRONMENTAL STUDIES FOR PEAT RE.SOURCE DEVELOPMENT

FUNCTIONAL ENVIRONMENTAL

DATA REOUIREMENTS

INITIRL LIMITED

CINSITE SURVEYS

LOCAL CONTACTS

AERIAL/PHOTO

STATE CONTACTS

AND DATA BASES,

PUBLISHED REPORTS

\section{AQUATIC ECOSYSTEM ANALYSIS}

Fisheries Cormercia /Other Recreational

Molluscs/Invertebrates

Birds, Water $=0 w 1$, and waders

Vegetation

Net Product ipity

General Resource Value

Commercial and Recreational Uses

Rare and Endangered Species and

Unique Habitats

Reclamation Potential

Integration with of =site Species

Breeding and Feeding Areas

Reptiles and Amphib-ans.

$\begin{array}{ll}x & x \\ x & x \\ x & x \\ x & x \\ x & x \\ x & x \\ x & x \\ x & x \\ x & x \\ x & x \\ x & x \\ x & x\end{array}$

\section{SOCIO ECONOMIC AND LAND USE FEATURE ANALYSIS}

Ownership

Current Use

Access

Market Land Values

Agriculture, Silvicultural Use

Infrastructure

Future Use Designations

RECONNAISSANCE

Ut i lity Requ'rements

Power Needs for Area

Reclamation Potential

$x$
$x$
$x$
$x$
$x$
$x$
$x$
$x$
$x$
$x$
$x$

Growth Attitudes

Taxes

Solid Waste disposal

$x$
$x$
$x$
$x$
$x$
$x$
$x$
$x$

$\begin{array}{rr}x & x \\ x & x \\ x & x \\ x & x \\ x & x \\ x & x \\ x & x \\ x & x \\ & x \\ & x \\ & x \\ & x\end{array}$


merely included here to illustrate their relative position in relation to the overall program. Each participating state could establish small experienced. environmental research groups to analyze these work elements. As denoted in Table 5.2 and Table 5.3, the majority of state environmental information would evolve from state and local contacts, previous data surveys and observations, and limited aerial reconnaissance and onsite surveys. It should be noted that this environmental reconnaissance phase will not include extensive detailed field investigations which will await later site specific surveys for specific projects.

Data to be gathered and analyzed during Phase II should be sufficient to meet each state's environmental demands when supplemented with later site specific data gathered from a project developer's study. The potential methodologies for developing the environmental data is detailed in Table 5.3.

Within each state the data should be collected and compiled and reproduced so that future peat resource developers and policy makers would have access and use of the data for decision making purposes.

In order for the environmental program to proceed, specific work assignments, mutual agreements, and understandings will have to be concluded between the DOE, participating states, and Federal agencies. As illustrated in Figure 5.1, defining: specific workscopes for the environmental program will be a difficult task due to the large number of participants, the diversity of their backgrounds, and the varying professional interests in the program. At the onset of the program, the precise nature of the project to promote and develop peat energy resources should be stressed and the environmental data gathered should be limited to that level necessary for the project formulation.

The formulation of specific workscopes within the participating states will evolve principaliy as a function of the states' individual data requirements, the DOE program requirements, the demands of Federal agencies, the views of participating researchers, organizational factors, and the nature of the environmental conditions within the state. Within this diverse management framework 
TABLE 5.3

Potential Sources of Local Instate Environmental Data Potential Subject, Data Bases and Knowledge

AGENTS

Climatologist

Forestry Department

Fish and Wildlife Departments

Division of Lands, Forests, Parks

Recreational Department

Division of Air \& Water Pollution Control

Soil Conservation Service

State Utility Commissions

County Tax Assessor
GENERAL DATA AVAILABILITY

Air pollution climatology, climatic variables of peat drying, seasonal climatic dates

Timber resuurce values, pulenlid reclalldtion programs, timber industry values, potential productivity gains

Data self-explanatory and permits

Management objectives, ownership patterns, park locations, peatland ownership, environmental protection

Outdour recreational use and values, prime recreational lands, management objectives

Data self-explanatory and permits

Air photos, resource values, drainage controls, reclamation potentials, climatic data, soil data

Location of existing facilities, net growth trends and needs, energy planning goals

Ownership status, net land values, reclamation land values 


\section{AGENTS}

County Road Departments

Local Public Officials

State and Local Universities

Agricultural Extension Service

Local Botanical Societies

State and Local Natural History Museums

Local Newspapers

Fish and Game Organizations

State Geologists

Coastal Zone Management Office

Federal Park \& Forest Managers
GENERAL DATA AVAILABILITY

Roadway access, load limits, flood dangers, drainage analysis

Infrastructure, local development attitudes and values

Natural and socioeconomic resource data

Land values, reclamation, crop potential, soils, climatic data

Existing species, rare and endangered species

Existing species, rare and endangered species

Socioeconomic data, local concerns, problems and needs

Local resource values, usage, types and importance of mineral leasing

Peat resource data, surficial and deeper geology, groundwater resources

Wetlands and energy siting issues, resource base

Federal land use, ownership and management objectives, land values, climatic data 


\section{TABLE 5.3 (Cont'd)}

AGENTS

Corps of Engineers

Federal Housing Administration

State Clearing Houses

State, County, Division Land Use Commissions

Public Health Commissioner

River and Watershed Commissions
GENERAL DATA AVAILABILITY

Floodplain and waterway management, flood potentials, salt water intrusion

Local floodplains and flood-prime areas

Existing EIS's prepared in the area, current development trends

Future and existing land use trends, infrastructure, environmental conditions; permitting procedures

Water quality and potable water supplies

Water quality, water resource, and land use data, water resource problem areas, potable water supplies 
the program objectives and requirements should be stressed and less emphasis should be placed on structured workplans detailing how the individual participants will accomplish their respective tasks. Initially, an effort to orient the researchers to the goals of the state and Federal peat development should be initiated. Subsequent monitoring and coordination will be required to ensure the program goals are met.

In addition to the state field environmental analyses, as 1isted in Table 5.2, environmental impact issue analyses work elements must be centrally analyzed. Since the issues analyzed by this program would be common to most peat development projects they should be addressed from a single authoritative viewpoint. While impact analyses could be developed by both Federal and state analysts, it is recommended that the majority of the programmatic qualitative and quantitative environmental impact analyses be conducted by cooperating Federal agencies for both convenience and program control. The specific work elements considered in this category are the formulation of qualitative and quantitative impact models and standard methods of impact analysis for air and water pollution, water resources, and biological effects of peat development. These elements should be located within the Federal agencies who have particular expertise in dealing with complex environmental model analyses.

The Federal agencies who have particular expertise within the environmental analysis areas are denoted in Table 5.4. As noted in Table 5.4 there may be a number of agencies having particular experience within a given area, consequently, DOE management decistons w111 have to be made concerning which agencies should participate in the peat program.

Participating by the peat resource states should not be precluded from the impact modeling process. The control of a coodinated research program between state environmental and Federal agency impact modelers will rely on close management support. The DOE program management should interface between these two programs and ensure the compatibility of the two work efforts. The additional issues as discussed in Chapter 3 and Appendix $A$ which are related to health and safety, regulatory, and solid waste issues should be analyzed by Federal interagency support. 
TABLE 5.4

FEDERAL AGENCY (EXPERTIZE)

\begin{tabular}{|c|c|c|c|c|c|c|c|c|c|}
\hline & \multicolumn{3}{|c|}{ AIR, ENVIRONMENT } & \multicolumn{3}{|c|}{ WATER \& AQUATIC RESOURCES } & \multicolumn{3}{|c|}{ TERRESTRIAL ENVIRONMENT } \\
\hline & $A$ & B. & $C$ & A & $B$ & $C$ & $A$ & B & $C$ \\
\hline EPA & $\star$ & * & * & * & $\star$ & * & & * & $\star$ \\
\hline $\begin{array}{l}\text { Department of } \\
\text { Agriculture } \\
\text { Soil Conservation } \\
\text { Service }\end{array}$ & & & & & & & $\star$ & & . \\
\hline $\begin{array}{l}\text { Agriculture } \\
\text { Research Service }\end{array}$ & . & & & $\star$ & $\star$ & & & $x$ & \\
\hline Forest Service & & & & * & $\star$ & & $\star$ & 7 & $\star$ \\
\hline $\begin{array}{l}\text { Department of } \\
\text { Interior } \\
\text { Geological Survey }\end{array}$ & & & & $\star$ & * & $\star$ & $\star$ & r & \\
\hline $\begin{array}{l}\text { Fish and Wildlife } \\
\text { Service }\end{array}$ & & & & $\star$ & $\star$ & * & $\star$ & $x$ & $\star$ \\
\hline $\begin{array}{l}\text { Bureau of Land } \\
\text { Management }\end{array}$ & & & & & & * & $\star$ & r & * \\
\hline $\begin{array}{l}\text { Department of } \\
\text { Commerce } \\
\text { National Oceanic } \\
\text { and A:mospheric } \\
\text { Administration }\end{array}$ & $\star$ & & & & & & & & \\
\hline $\begin{array}{l}\text { Office of Coastal } \\
\text { Zone Management }\end{array}$ & & & & $\star$ & * & * & * & & * \\
\hline
\end{tabular}


TABLE 5.4 (Cont'd)

FEDERAL AGENCY (EXPERTIZE)

AIR ENVIRONMENT WATER \& AQUATIC RESOURCES TERRESTRIAL ENVIRONMENT

National Marine Fishery Service

Department of Defense Army Corps of Engineers

Department of Health, Education and Welfare

Water Resources Council

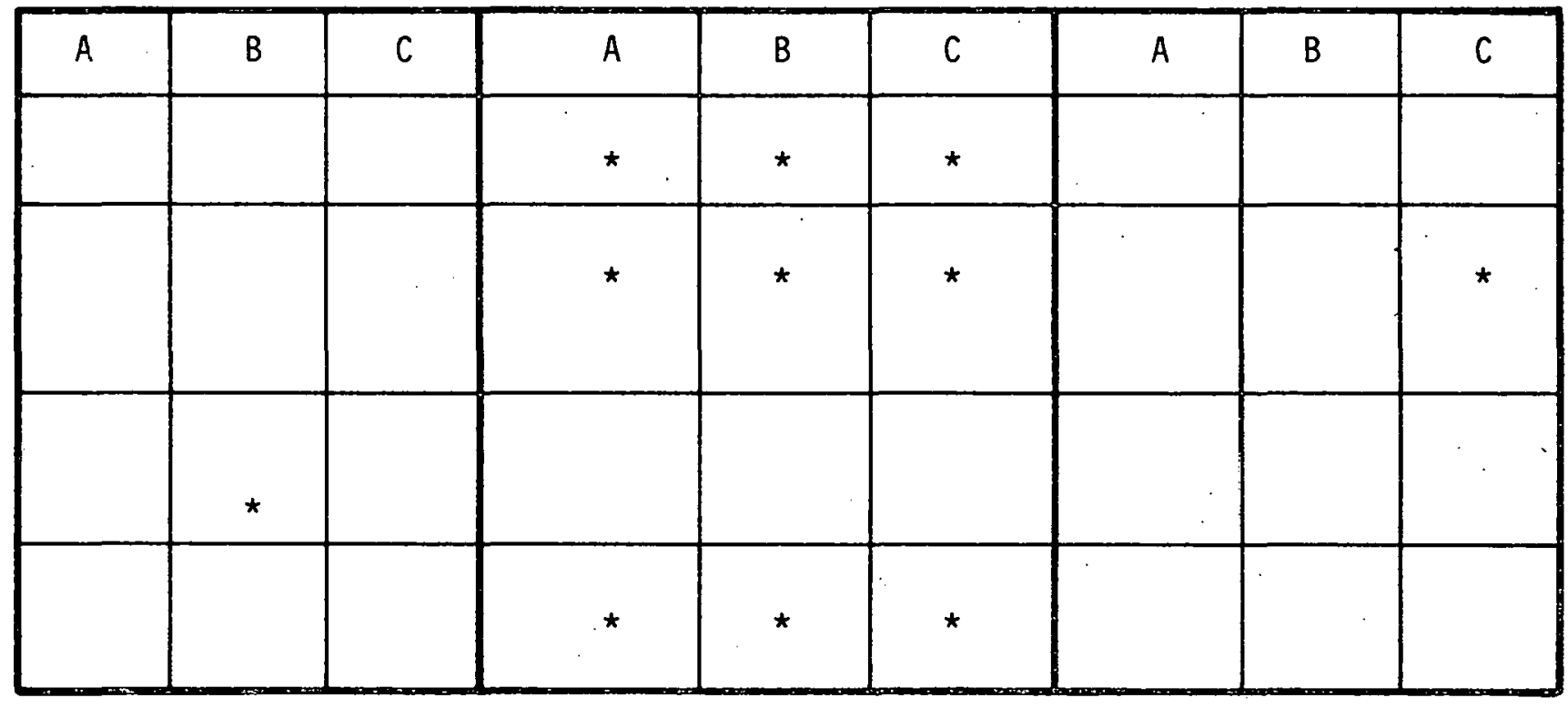

A. Environmental Inventory c.nd Background Data

B. Environmental Modeling and Impact Analys is

C. Issue Permits and Regulations 
The environmental inventories studies and impact analyses developed in Phase II should be closely controlled to ensure the studies do not go beyond the intended objectives. A serious fault of this type of an environmental program is that the level of environmental studies can become too complex and unmanageable for inclusion into a general evironmental impact assessment. Under these conditions the peat environmental program could suffer from too little generic environmental data for a thorough peat Environmental Impact Assessment or for the formulation of rational peat development policies. 


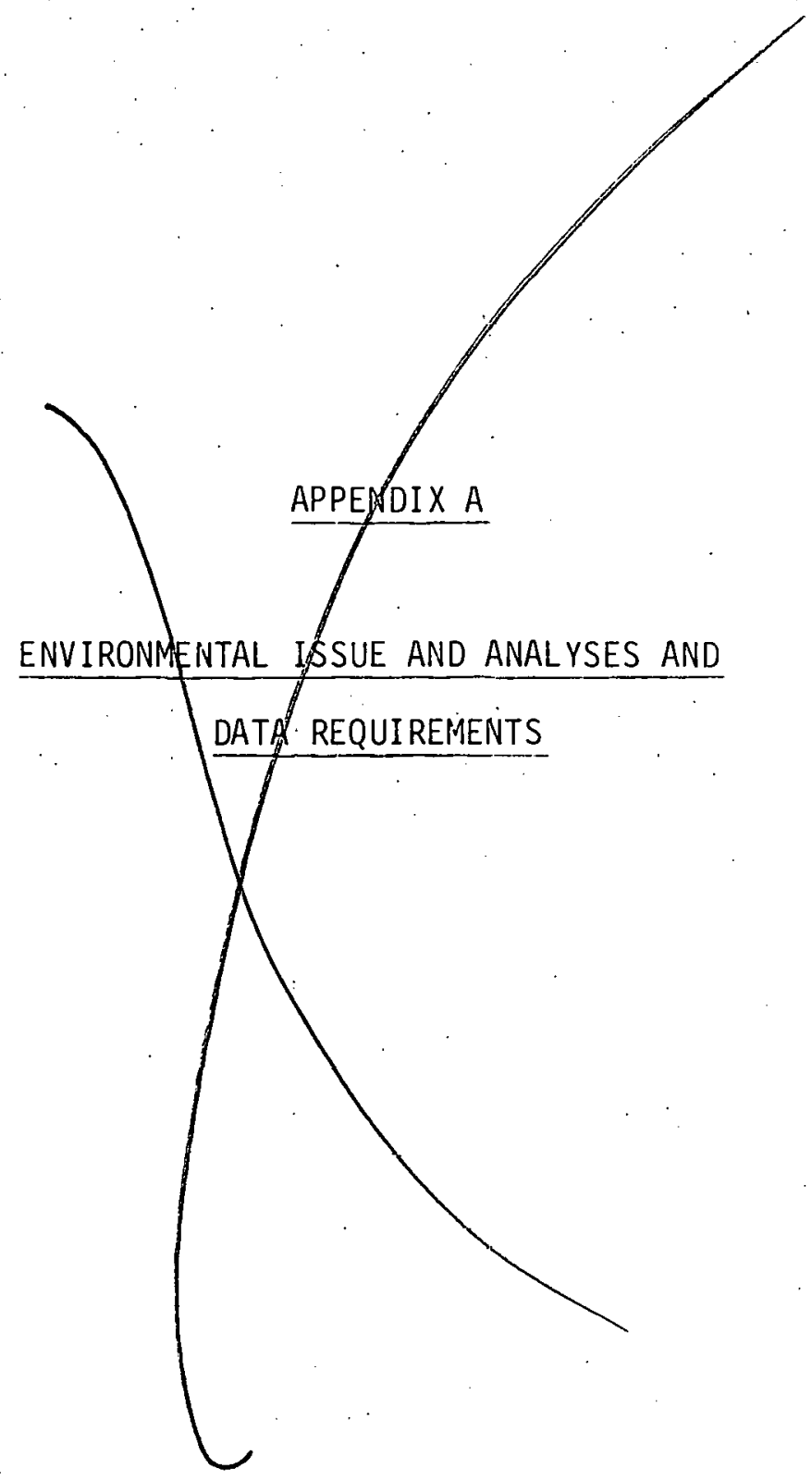

A-1 


\section{APPENDIX A}

\section{ENVIRONMENTAL ISSUE AND ANALYSES AND}

DATA REQUIREMENTS

Appendix A summarizes analyses of the Environmental Issues identified in Chapter 3 and presents lists of state and Federal actions needed to resolve each issue. The analysis summary for each Environmental Issue includes Legislative/Institutional Concerns, Environmental (or Public) Interests, Environmental (or Health and Safety) Goals, and the Action/Data Requirements with respect to state and Federal activities. The same section numbers used for the issues presented in Chapter 3 are retained to facilitate comparison with analyses of the same issues which are summarized in this appendix.

The Legislative/Institutional Concerns sections summarize the regulatory aspects of each particular Environmental Issue. In some instances, specific Federal and state laws and regulations have been enacted and promulgated to define standards, whereas in other instances legislation and conventions have evolved into established patterns without definitive regulations and standards. Nonregulated Environmental Issues are further described in Environmental (or Public) Interests sections which highlight the attitudes and perceptions of the public at large and of environmental organizations.

The Environmental Goals sections identify the project design criteria for each Environmental Issue. The attainment of these criteria would be the objective of environmental impact initigation plans which should be initiated at this early stage of peat energy policy development.

Finally, Action/Data Requirements are divided between the individual states and the Federal governments. The Requirements are structured to allow for efficient Federal and state analyses and data transfer and for the designation of the most logical candidate agency for each given task. Federal and state agencies should be able to complete the environmental data gathering and policy development 
effort needed to support the large-scale commercialization of energy from peat within a three-to-four year period. 
The potential for increased flooding is a critical concern for all downstream water users and residents in flood-prone areas. For this reason, any potential increase in flood flow volumes will be closely scrutinized by local and state agencies. Under riparian water rights, as well as, western adjudicated water resource doctrines, any development that causes, or can be shown to cause, increased flood levels can be legally blocked or be the cause for seeking damages.

\section{ENVIRONMENTAL INTERESTS}

In addition to the legal implications of increased floodwaters, these increases have severe consequences on downstream land uses, riparian habitats, and aquatic resources. Impact on any one of these will necessitate an environmental analys is under existing state and federal permits and will be carefully scrutinized by downstream land holders and environmental groups. 


\section{ENVIRONMENTAL GOALS}

Because of the various hydrological modifications that the watershed will undergo during site preparation, peat harvesting, and reclamation, a proper hydrological control plan will have to be formulated to minimize hydraulic impacts on downstream floodplain resources. Formulation of this mitigative plan will need to be on a site-by-site basis.

\section{ACTION/DATA REQUIREMENTS}

State - Water Resource Agencies and Basin Commissions: Define downstream flood prone areas that should be protected from potentially large and moderate scale peat development at upstream sites.

Within states, a number of state and federal agencies have data on flooding. Special interest should be on downstream floodplain mapping. The study should concentrate on a downstream potential impact area equal to approximately 15 times the size of the projected harvest area. In immediate downstream floodprone areas containing residential and commercial buildings, a more thorough analys is should be conducted. For small remote peatlands of less than 1,000 acres and no immediate downstream commercial or residential development, it is not necessary to conduct the analysis during the generic studies. A number of states have established flood predictive models. These models can be used to determine present peat development scenerios. Models should be reviewed for the incorporation in the overall DOE Peat Development program.

DOE - In conjunction with the appropriate federal agencies develop a peatland flood and downstream flood routing model that will:

- Define the impact of change in hydrology in relation to the size of the harvested area. 
- Simulate rainfall and snowmelt flood responses from various harvesting. and reclamation techniques.

- Simulate flood responses for single and multiple site locations most suitable for moderate and large scales of development.

\section{WR 3.4.2 Groundwater Elevation Modification}

\section{LEGISLATIVE/INSTITUTIONAL CONCERNS}

The control and management of peatlands groundwater elevation should be discussed since most states have enacted regulations protecting their groundwater resources. Anticipated federal regulations will be designed to protect both quantity and quality of groundwater resources.

\section{ENVIRONMENTAL INTERESTS}

Local and regional environmental interest groups are very sensitive to changes in groundwater resources, especially if the aquifer is used for private or public water supply within the immediate environs, or if the aquifier is hydraulically coupled with surface water that is used for recreational, wildiffe, or other purposes.

ENVIRONMENTAL. GOALS

ACTION/DATA REQUIREMENTS

State - If the peatlands are small and remote, it could be assumed that little groundwater is used, and this issue should only be addressed briefly. However, a more rigorous groundwater analys is should be conducted where the peatlands are known or suspected contributors to a major, actively used aquifier. The potential size and location of the developed peatland should dictate the size of the study area and emphasis that should be placed on this issue. 
- Briefly detail the basic types, conditions, and mechanisms of the groundwater resources within the state's peatlands.

- Determine the status of the aquifier's quality and use within these areas.

- Groundwater resources along coastal peatlands should be analyzed to determine the extend of saltwater intrusion and current pressures on fresh water aquifiers. Where groundwater data is lacking, a more detailed field investigation should be developed.

DOE - In conjunction with appropriate federal agencies, develop:

- Groundwater drainability models for various peatland types such as minerotropic and ombotrophic, fens; depression bog, perched depressed bogs, and coastal peatlands.

- Methods by which bogs can be identified if hydraulically coupled with local or regional groundwater aquifiers.

- Groundwater models to simulate dynamic groundwater level changes, drainage characteristics, and outflows in response to storm events, snowmelt, changes in interflow, peat wetability changes in peat storage capacity, hydraulic transmissibility, and differing peat harvesting and drainage techniques.

WR 3.4.3 Potential Saltwater Intrusion Along Coastal Areas

\section{LEGISLATIVE/INSTITUTIONAL CONCERNS}

The development of an energy facility in the coastal areas will come under the review of the state coastal zone management programs and water resource managers who must evaluate the potential dangers caused by saltwater intrusion. 
An activity on, or adjacent to, the marine coastal zone management areas that could possibly affect the established surface and groundwater freshwater-saltwater balances of the area would come under close review by local environmental and commercial fishing organizations.

\section{ENVIRONMENTAL GOALS}

The environmental goals of coastal peatland development should be to manage the area's surface and groundwater resources so as not to cause any net changes in the dynamic freshwater and saltwater contact zones.

\section{ACTION/DATA REQU IREMENTS}

State - Identify boundary of saltwater intrusion in relation to potential peat resource areas.

- This topic should only be addressed for large scale developments where drainage ditches construction could lead to saltwater intrusion problems. For small to moderate inland development along the coastal plain, analyses should be conducted only after generic analyses show that adverse influences could be generated.

DOE - - In conjunction with the appropriate federal agencies, prepare a generic study of potential saltwater encroachment from the drainage and harvesting of coastal peatlands.

- Determine management and control strategies that can be used to preclude saltwater encroachment. 
WR 3.4.4 Modification of Surface Water Flow Patterns

\section{LEGISLATIVE/INSTITUTIONAL CONCERNS}

Within a peatland, the rearrangement of the surface drainage to or from an area causes public concern as to what will happen to the area surrounding the harvest site. For these reasons, state and federal laws have been enacted to minimize the downstream flooding and offsite ponding resulting from changes in the area's surface flow patterns. The agencies who would evaluate drainage changes are the state and federal environmental protection agencies, fish and wildlife services, water resources commissions, Corp of Engineers, and local soil and water conservation commissions.

\section{ENVIRONMENTAL INTERESTS}

The loss of wetlands from drainage or ponding has become a critical local, state, and federal environmential issue. Any project within a peatland area will be reviewed for the immediate impacts within the site and potential effects of surface drainage changes offsite. Wetlands protection legislation in most states can be used by environmental groups to constrain development when drainage impacts can be demonstrated.

\section{ENVIRONMENTAL GOALS}

The environmental goals for this issue will be to design drainage control programs that minimize immediate and far field impacts. Offsite impacts to be considered are: maintenance of surface water flows to non-worked and offsite areas; prevention of ponding; rearranging surface flows to preclude downstream flooding and, in some areas, to preclude the chances of saltwater instrusion. 
State - Review past operations of roadways, drainage ditches, pipelines, large facilities, agricultural drainage, and powerline rights of way to determine the occurrence and control of drainage rearrangement impacts on surrounding peatlands and wetlands.

- Conduct field investigations on similar environments within the state to document the hydraulic and environmental changes that have occurred from previous wetland operations.

- Determine the best management. and construction practices should be determined that will minimize alterations of the natural surface flow patterns.

DOE - - Contact the respective peatland states to determine operational experiences with wetland and peatland drainage problems.

\section{WR 3.4.5 Minimum Stream .Discharges}

\section{LEGISLATIVE/INSTITUTIONAL CONCERNS}

Since peatlands are located in the north central, north, and southeastern U.S., the riparian doctrine of water use allocation does not specifically forbid the increase of minimum streamflows. Under this doctrine, if the flow increase do not lead to direct or indirect impacts on downstream water users or adversely affect water quality, the increased flows will be allowed.

\section{ENV IRONMENTAL INTERESTS}

The environmental interest in increasing streamflow volumes is generally beneficial. Minimum streamflow volumes are used to indicate the limitations of the hydraulic system with respect to water quality criteria, downstream water users, and aquatic ecosystems. 
Peat extraction programs should not decrease minimum streamflow volumes, instead they should maintain or increase minimum streamflow volumes regardless of the selected development or reclamation procedure.

\section{ACTION/DATA REQUIREMENTS}

State - Determine the minimum 1, 7, 15, 30, and 60 day low flows for the state's peatland areas.

In most states, the state geological surveys or water resource agencies could calculate low flow streamflow data which could be used for the peatland areas. The general areal extent of this hydrological analysis should be kept to a reasonable area where the low flow influences would not be impacted. After the generic hydrological model is completed, the net peatland low flow contribution in CFS (cubic feet per second) will determine the limits of influence. In cases where there are immediate downstream surface water users or the area has restricted low flows for water supply or habitat protection, more emphas is should be placed on data gathering and analyses. For potential large development areas in excess of 5,000 acres, subdivide the area into the respective sub basins and proceed with a similar analysis. In states which could have multiple bog development scenerios, from a single development scheme, increase the impact zone in a manner commensurate with the sum of the individual peatlands being developed.

DOE - With the appropriate federal agency, develop peatland hydrologic models that will be applicable to the areas envisioned for development, scales of development, and for the specific methods of peat extraction. 
WR 3.4.6 Increase Surface Mean Water Discharges

\section{LEGISLATIVE/INSTITUTIONAL CONCERNS}

The release of additional surface water to a riverine or estuarine system must be analyzed to determine net effects on downstream water users. If the discharge volumes are within the normal seasonal fluctuations and poor water quality discharges are made under the NPDES all water quality and aquatic ecosystem impacts would be expected to occur. Facility and field drainage water discharges would require state discharge permits and an evaluation of the net effects of these discharges on the downstream water resources.

\section{ENV IRONMENTAL INTERESTS}

The release of water from a drainage and process system requires state and federal water quality discharge permits. The issuance of these individual permits is closely reviewed by public interest groups and downstream water users.

\section{ENV IRONMENTAL GOALS}

The discharge of any process or drainage water from the project should be carefully controlled to reduce impacts on the downstream water quality and surface flow volumes. Environmental limitations on these releases should be to keep the water volumes within the normal daily and seasonal fluctuations of the receiving waterbody.

\section{ACTION/DATA REQUIREMENTS}

State - with single, small scale developments of less than 1,000 acres, the effect of increased discharges on mean streamflows would be minimal and within the stream's normal flow fluctuations. However, for moderate and large scales of development, this issue should be reviewed on the watershed basis. Large developments will require state criteria for acceptable surface discharges in order. to protect downstream water users and aquatic resources. 
- For watersheds that have a high probability for peat development, determine the mean monthly flows and deviations.

- Determine the levels of additional flows that can be safely accommodated within the respective receiving streams.

- Identify data gaps and water resource requirements for future projects.

DOE - From a systems analysis viewpoint, develop a drainage and dewatering model to define the amount of water that will be released from the various harvesting and peat dewatering options and define these discharges on a seasonal basis.

WR 3.4.7 Alter the Hydrological Budget

\section{LEGISLATIVE/INSTITUTIONAL CONCERNS}

A primary concern with any moderate or large-scale wetland development is the net effect it will have on the areas water resources. A comprehensive and dynamic hydrologic model should be developed to indicate where these changes will occur. The model outputs would be analyzed by the state and federal authorities who have jurisdiction over flood control, soil and water resource management, and fisheries management.

\section{ENVIRONMENTAL INTERESTS}

Changes in the hydrologic budget of an area will produce changes in water resources originating from the project area. Satisfying local and regional concerns on the impacts on water resources and aquatic resources will be part of any planned development. 
ENVIRONMENTAL GOALS

The environmental goals of a study which uses hydrologic modeling would be to define the peat/water relationships of the project, to identify potential changes in the areas water resources, and to minimize impacts of development and reclamation.

ACTION/DATA REQUIREMENTS

State - 0 Classify the hydrological regime of the state's peatlands and construct a prelliminary hydrologle budyel of lhe resuuries.

- From the existing water resource data account for the annual major inputs and outputs of the peatland hydrological budget.

- Determine applicable water resource data for input into the dynamic modeling effort being conducted in the federal programs.

- Identify water resource data gaps to enable data collection during later project phases.

DOE - Develop a general, dynamic hydrologic model to scale the important elements of the hydrologic cycle within a peatland. The model will predict the changes that will occur as a result of various development and reclamation schemes.

WR 3.4.8 Alter Groundwater Aquifers

\section{LEGISLATIVE/INSTITUTIONAL CONCERNS}

Both federal and state statutes have been enacted for groundwater resources protection from surface disturbance. The recently enacted surface mining regulation (SMCRA-1977) recognizes that preserving groundwater resources may preclude mining if direct groundwater users are affected and if the mining occurs within unconsolidated aquifers of an alluvial valley. 


\section{ENVIRONMENTAL INTERESTS}

Whenever there is a chance that groundwater resources may be irreparably harmed by surface mining activities, local and national environmental awareness and pressure would focus on this issue.

ENV IRONMENTAL GOALS

Define what the net hydrological changes on the groundwater environment will be and determine whether this constitutes a significant impact on the maintenance of the area's: groundwater resources.

\section{ACTION/DATA REQU IREMENTS}

State - - Gather data and assess the groundwater usages within the potential areas of peat development.

- Within peatlands which have a high probability for development, define the consolidated and unconsolidated aquifers, their major recharge zones, and connection with peatland areas.

- Data on the major groundwater aquifers and their usage should be superimposed on a peatland map to define better relationships. If these two areas are mutually exclusive, no further analysis should be conducted on peatland areas considered for small and moderate scales of development. However, where a large scale development could encounter, a principal aquifer, a metropolitan water suppliers efforts should be made with the federal effort to model this specific area.

DOE - In conjunction with the appropriate federal agencies, develop a groundwater modeling program to stimulate the effects on deeper consolidated and surficial aquifers from a peat harvesting and reclamation development. 
WR 3.4.9 Reduce the Evapotranspiration Rate

\section{LEG ISLAT IVE/I NSTI TUTIONAL CONCERNS}

Currently, there are no direct regulations concerning changes in evapotranspiration. However, under federal and state environmental protection laws, a large scale development project will need to analyze this factor with respect to potential local climate modification and changes in adjacent plant and animal communities.

\section{ENV IRONMENTAL INTERESTS}

Because of the significant size of the large scale peat projects, changes in evapotranspiration over such a large surface area requires an analysis of the eventual hydrological and climatological changes that could result. Residents living adjacent to a large project would be concerned with potential changes in microclimate, of which possible change in evapotranspiration would be a major component.

ENVIRONMENTAL GOALS

The environmental goal would be to control evapotranspiration during peat harvesting and reclamation to reduce offsite impacts. In addition, it may be possible to use evapotranspiration techniques as an aid to insitu field dewatering.

\section{ACTION/DATA REQUIREMENTS}

State - Determine, by contacting local and state agencies, and peat harvesting operators, the availability of bog or dryland evaporation and evapotranspiration data.

- Review available hydrological data to determine net peatland crapotranspiration rate. 
WATER QUALITY ISSUES

WQ 3.5.1 Low pH Discharges.

LEGISLATIVE/INSTITUTIONAL CONCERNS

Water from drainage, dewatering facilities, and process discharges must meet state effluent discharge standards for $\mathrm{pH}$ and must maintain the designated water quality. classifications of the recelving stream.

\section{ENV IRONMENTAL INTERESTS}

Changing ambient stream. pH values has become an important issue in fossil fuel development. Most environmental organizations on local and regional levels would be expected to closely scrutinize and comment on any changes in the receiving stream's $\mathrm{pH}$ water quality. The problem would become especially acute if there are immediate downstream surface potable water users, or prime aquatic habitat resources: 


\section{ENVIRONMENTAL GOALS}

All discharges from peat development will have to be controlled to meet state and federal existing discharge standards and not alter $\mathrm{pH}$ values of the receiving stream from the established criteria.

\section{ACTION/DATA REQUIREMENTS}

State - 0 The state agencies should determine if any natural pH water quality impacts or stresses are occurring on the fisheries and fish habitats. States should estabilish how pH controls the diverse aquatic communtties.

- Water quality data should be reviewed to determine seasonal fluctuations and range of $\mathrm{pH}$.

- Gather existing $\mathrm{pH}$ and buffering data from peatland and downstream waters.

- Review discharge permit files for water quality data resulting from arainage of pcatlands.

- Define existing cases of water quality problems with peat dewatering operations.

DOE - - Gather water quality pH data from experimenld hydraulic mining operations and other ongoing peat harvesting and dewatering operalluns.

- In coordination with other federal agencies, screen the computerized water quality records for data on peatlands.

- Develop a general pH prediction model for downstream water quality dynamics. 
- Define potential pH controls which can be implemented within various development scenarios, such as natural buffering water treatment.

- Determine the water quality experiences from the European peat harvest operations.

WQ 3.5.2 Discharge of High BOD/COD

\section{LEGISLATIVE/INSTITUTIONAL CONCERNS}

Both the federal government and states have water quality protection regulations and effluent standards governing BOD and COD discharges. Presently, no applicable federal effluent standards under the National Pollutant Discharge Elimination (NPDES) System for release of process water from peat harvesting and processing have been established. With the development of large scale operations, water pollution standards governing BOD and COD discharges would be expected in order to maintain designated stream water quality classifications.

\section{ENV IRONMENTAL INTERESTS}

The discharge of water containing $B O D$ and $C O D$ from the peat harvesting and process facilities will come under the scrutiny of various local and regional environmental groups, who persistently monitor potential impacts to states' water quality and aquatic environments. Through state and federal permit procedures, public interest in the project impacts on water quality would be reviewed through local public hearings.

ENVIRONMENTAL GOALS

The citizen's environmental goals would be to protect the receiving water dissolved oxygen levels needed to protect their fishery resources. 


\section{ACTION/DATA REQUIREMENTS}

State - The BOD/COD data collection should be primarily concerned with gathering published and unpublished data and observations from natural and developed peatland discharges. Where environmental data is, lacking, collection strategies to gather data from representative peat harvesting operations should be developed. The nature of oxygen demands and reaeration coefficients would be site and project specific. Where the state has specific reaeration models for simulating stream oxygen deficiencies modeling. should be conducted to determine maximum allowable RחM/c.nn discharge limit.s from high pot.ential develnoment. areas. The results of these analyses should be used in conjunction with the federal generic modeling effort.

- Review pollution case histories to determine the significance of bog water discharges on downstream oxygen deficiencies.

- Collect published and unpublished BOD, COD, and 0xygen level water quality data from disturbed and undisturbed peatlands.

DOE - - Assemble BOD/COD discharge data from peatland operations on federal lands and activities.

- Obtain water quality discharge data from wild rice and cranberry bogs to determine potential water quality problems from the hydraulic harvesting scheme.

- Review the treatment potentials for treating process, dewatering, and drạinage waters.

- In cooperation with other federal agencies, develop a BOD/COD reaction and reaeration model for potential wastewater discharges.

- Review potential discharge permits to identify need for effluent guidelines. 
Fishery management strategies within peatland drainages should be documented. If current peatland dewatering operations are being conducted in the state, investigate the impacts of these discharges through agency contacts. Where specific state eutrophication models have been developed, determine the nutrient loadings which can be accepted from a potential peat development operation. This effort should be coordinated with the generic modeling effort.

- Establish clear nitrogen and phosphorous discharge concentration criteria for bog drainage waters and process water.

- Define effluent standards and methods, timing and location of sample measurements.

- Determine where no nutrient discharges can be made.

DOE - Determine the effect of discharge on eutrophication rates.

- Develop water quality models to determine the release of nutrients from hydraulic mining, dewatering, and field drainage programs.

- Monitor water quality effluent data from ongoing peat harvesting operations and dewatering operations.

- Develop eutrophication rates and water pollution control strategies based on the above two requirements.

- With interagency support, review the current computer models used to define eutrophying reactions in the aquatic and estuarine environment. 
WQ 3.5.3 Nutrients

\section{LEGISLATIVE/INSTITUTIONAL CONCERNS}

The discharge of nutrifying elements such as nitrogen, phosphorus, and other biostimulants is closely controlled by permits and other stipulations to maintain ambient water quality classifications. Since undisturbed peatlands are remotely located, discharges may be held to the most stringent state water quality requirements. In this context, the state pollution abatement programs would have to be designed to maintain the water quality of the area.

\section{ENVIRONMENTAL INTERESTS}

Local and national environmental groups have always been concerned over significant changes in the sources of nutrients that could eutrophy an aquatic lacustrine or estuarine ecosystem. The concerns of discharging increased nitrogen and phosphorus levels must be considered for the drainage and reclamation stages.

\section{ENVIRONMENTAL GOALS}

The main goal of the water pollution control strategy would be to limit the addition of deleterious nutrients to normal runoff values and not to alter adversely the natural nutrient loadings of the receiving streams.

\section{ACTIION/DATA REQUIREMENTS}

State - The state water quality analysis program should be focused on gathering the available published and unpublished water and peat quality data within the developable areas of the state's peatlands. Where the data is lacking, data gaps should be noted. Field data should not be conducted during this phase. Areas currently experiencing eutrophication impacts should be addressed as they pertain to peatland drainages. 


\section{ACTION/DATA REQUIREMENTS}

State - The BOD/COD data collection should be primarily concerned with gathering published and unpublished data and observations from natural and developed peatland discharges. Where environmental data is lacking, collection strategies to gather data from representative peat harvesting operations should be developed. The nature of oxygen demands and reaeration coefficients would be site and project specific. Where the state has specific reaeration models for simulating stream oxygen deficiencies modeling should be conducted to determine maximum allowable BOD/COD discharge limits from high potential development areas. The results of these analyses should be used in conjunction with the federal generic modeling effort.

- Review pollution case histories to determine the significance of bog water discharges on downstream oxygen deficiencies.

- Collect published and unpublished BOD, COD, and 0xygen level water quality data from disturbed and undisturbed peatlands.

DOE - - Assemble BOD/COD discharge data from peatland operations on federal lands and activities.

- Obtain water quality discharge data from wild rice and cranberry bogs to determine potential water quality problems from the hydraulic harvesting scheme.

- Review the treatment potentials for treating process, dewatering, and drainage waters.

- In cooperation with other federal agencies, develop a BOD/COD reaction and reaeration model for potential wastewater discharges.

- Review potential discharge permits to identify need for effluent guidelines. 


\section{WQ 3.5.4 Chemical Compounds}

\section{LEGISLAT IVE/I INSTI I TUT IONAL CONCERNS}

At present, there are no effluent or water quality standards for organic acids. Organic compounds cause taste and odor problems, however, standards for their concentration are more qualitative than quantitative.

Heavy metals discharge from industrial processes is governed under the state and federal effluent standards. These standards are designed to reduce the net effluent discharges and comply with state water quality classifications. However, currently, there are no effluent standards for peat processing facility discharges.

With Toxic Substance Control Act (TSCA), Resource Conservation and Recovery Act (RCRA), and the amendments to the Water Pollution Control Act, there is a growing awareness of potential toxic and carcinogenic properties of solid and $1 \mathrm{i}$ quid waste streams. These acts require a thorough study of direct wastewater streams and solid waste disposal systems to isolate and identify toxic products and necessitate development control strategies to prevent their release.

\section{ENVIRONMENTAL INTERESTS}

Where the potential exists to impact the taste, odor, and visual characteristics of a potable water supply, downstream surface water users would be expected to object to potential discharge levels and question the water quality control methods employed by the project.

Any parameter that could cause potentially adverse impacts on water quality and aquatic ecosystems will come under close public scrutiny. Research conducted in Minnesota has shown that mercury, arsenic compounds, and other elements are present in peatlands. These products could be released into the aquatic environment. 
The release or potential release of toxic and carcinogenic compounds is a sensitive issue with environmental groups and the public. Current regulations place the burden of proof on the industry to provide evidence that process discharges are safe, and compatible with the intended surface and groundwater uses.

\section{ENVIRONMENTAL GOALS}

The environmental goal is to limit the discharge of organic compounds to assure that aquatic species or potable water systems will not be affected.

Toxic compounds need to be identified, both in the peatland and processing facility, and water pollution controls must be established to prevent releasing these compounds into aquatic ecosystems.

\section{ACTION/DATA REQUIREMENTS}

State - - The state analysis for the environmental issue should be primarily focused on gathering existing data and observations concerning influence and occurrence of organic acids.

- Research reports and experiences relating to the problems associated with bog drainage, causing taste and odor problems.

- The natural occurrences of heavy metals in certain peatlands can often be determined by analyzing existing data on mineralization, and geochemistry of groundwater and surface water within the region. To limit expensive chemical studies--other less expensive avenues must be checked to determine if metallic anomalies exist. Peatlands may be the recipient of air pollution fallout containing heavy metals and other contaminants depending on their location. If field sampling is conducted, only limited spot checking would be required to determine the presence of heavy metals. 
- Conduct spot check trace cation analysis at most potentially developable peat resources in each state.

- From geochemistry data, determine if any peat areas within the state could receive high metallic groundwater inputs.

- Survey existing state data bases for toxic and carcinogenic substance released.

DOE - - Conduct generic research on the potential organic chemicals that san be naturally released from the peatlands and determine projected safe effluent concentrations of these chemicals.

- From current federal peatland development projects, determine the leaching potential during harvest and dewatering.

- Analyze liquid wastestreams from laboratory, PDU, or demonstration facility for organic compounds.

- Survey available literature to establish trace cations concentrations in peat and consult existing heavy metal bioassy data for aquatic organism tolerances.

- Gather existing water quality data on trace cations from peatland drainage areas.

- Conduct a study on cation movemient from drainage, dredging, and dewatering operations from existing federal programs.

- Confer with appropriate federal and state agencies to determine potential effluent standards that may be imposed on peat harvesting, dewatering, and energy processing. 
DOE - Conduct a thorough organic chemical analysis on natural and induced drainage from potential peat development areas.

- Analyze the organic chemicals from all effluent waste streams including dewatering discharges.

- Conduct leaching studies and water quality analyses of all process solid wastes residues.

- Determine the impact of any toxic or carcinogenic pollutants released to the water environment.

- Review these findings for TSCA and RCRA controlled substances and perform other carcinogenic and toxological tests on unknown compounds.

- In conjunction with other federal agencies, determine a specific field and laboratory testing procedures for toxological and carcinogenic properties.

- Determine foreign research results on this topic.

- Determine the environmental impacts and effects of these chernicals on potable water supplies.

- Conduct bioassay analyses on fish and other aquatic organisms with specific organic chemicals. 
WQ 3.5.5 Colloidal and Settleable Solids

LEGISLATIVE/INSTITUTIONAL CONCERNS

State and federal water effluent standards govern the discharge of total dissolved solids, and settleable solids, from various industrial processes. The discharge standards are established on an industry by industry basis and are formulated on the amount of process material. There is a lack of effluent standards for peat harvesting and energy production. However, effluent standards for mining and forest products industrial sectors would be used.

\section{ENVIRONMENTAL INTERESTS}

Objectionable water quality changes due to dissolved and settleable solids would come under close analysis by local and state environmental groups.

ENVIRONMENTAL GOALS

To control the discharge of solids, minimize important surface water resources.

ACTIUN/UAIA REQUIREMENIS

State - The state water quality program should be developed to research existing data sources during the initial phase of the program. A review of permitted discharges from peat drainage operations and potential site visits should be conducted on those suspected of discharging high dissolved and suspended solids.

- Review water quality problems that have arisen from peatlands drainage and management operations. 
* DOE - Identify potential bog dewatering operations that may provide data for future water quality research purposes.

- Coordinate with appropriate federal agencies on the potential peat development effluents standards.

- Gather water quality data from effluents from bog harvesting, rice or cranberry agricultural operations, hydraulic harvesting, peatland drainage, and lab and pilot plant dewatering operations.

- Consult with foreign peat producers to determine their experiences with water quality problems. 
AIR QUALITY ISSUES

\section{AQ3.6.0 General State Data Requirements}

During the initial phase of the environmental study conducted by the state, the air quality program should be structured to define ambient air quality and current air pollution control strategies. Much of this work has been done under the Clean Air Act requirements. State Implementation Plans provide the basis for control programs and should be consulted for the peat environmental program. For 1 ack of current peat extraction operation, air envasion and air quality modeling should be conducted on a generic basis by the DOE with inputs from the state programs as defined below.

The general state data requirements for the alr quality issues include:

- The characterization of the air pollution climatology and meteorology or juat regiuns.

- The characterization of the existing air quality network within the peat regions. 
- The development of historical data and trends.

- The identification of airsheds and the priority classifications from State Implementation Plans.

- The identification of non-attainment zones and priority pollutants which are currently in non-conformance.

- The projection of other developments which may compete for available PSD increments.

- The delineation of air emissions standards and control stretegies for the peat regions.

\section{AQ 3.6.1 Fugitive Dust}

\section{LEGISLATIVE/INSTITUTIONAL CONCERNS}

Total Suspended Particulates (TSP) are high on the EPA's priority list for control. Most areas in the U.S. have reported local or area-wide violations of National Ambient and Quality Standards (NAAQS) for TSP, including most peatrich areas. Local regulations also prohibit excessive fugitive dust emissions.

Prevention of Significant Deterioration (PSD) review may be required for fugitive dust emissions exceeding 10 tons per year; the appropriateness of inclusion of fugitive dust emissions for PSD review purposes is currently under EPA review. Peatlands may be near PSD Class I areas because of their remote wilderness locations, wildlife values and proximity to Indian reservations. No NSPS for peat operations exist. For comparison only, coal preparation plants are regulated by NSPS for thermal dryers $(0.031 \mathrm{gr} / \mathrm{dscf}$ or $0.070 \mathrm{~g} / \mathrm{dscm}$ with a monitoring requirement) and for preumatic coal cleaning equipment $(0.018 \mathrm{gr} / \mathrm{dscf}$ or $0.040 \mathrm{~g} / \mathrm{dscm}$ without a monitoring requirement). Processing and conveying equipment, storage systems, and transfer and loading systems must meet a $20 \%$ visual opacity regulation (no monitoring requiręment). 


\section{ENVIRONMENTAL INTERESTS}

Environmental groups and the public can be expected to oppose peat harvesting/ drying operations that cause significant emissions of fugitive peat dust. This will be especially true for the local impacted area and along transportation corridors.

Due to large open field peat storage requirements and several handling sequences, environmental groups can be expected to oppose peat storage and transportation activities that result in any significant release of fugitive dust.

\section{ENV IRONMENTAL GOALS}

The major goal is to prevent particles from becoming airborne throughout the various peat processing stages. Peat harvesting/drying technologies that do not create excessive fugitive dust emissions are needed.

Peat storage and transport technologies are required that do not expose dried peat to excessive storage and transportation losses.

\section{ACTION DATA REQUIREMENTS}

State - Refer to $A Q 3.6 .0$

DOE, in conjunction with appropriate Federal agencies, should develop fugitive dust emission models and establish emission factors.

The European experience in controlling fugitive dust during milled-peat harvesting should be surveyed.

The potential impacts of peat fugitive dust dispersion and fallout on terrestrial and aquatic resources should be estimated. 
Acceptable control technologies for milled-peat operations should be determined in conjunction with appropriate Federal agencies.

The seasonal aspects of the dry harvesting methods should be defined.

DOE

- Compare the costs and environmental factors for a wet harvest method with dry harvesting.

- Assess regional peatland weather and ambient TSP levels to provide data input for fugitive dust impact analyses.

- Consult with all applicable Federal agencies to determine their permit requirements for fugitive dust emissions from storage and handling equipment.

- Determine air quality impacts from current existing harvesting operations in European operations.

- Investigate the dust explosion control measures employed in Europe.

\section{AQ3.6.2 Carbon Monoxide}

\section{LEGISLATIVE/INSTITUTIONAL CONCERNS}

Due to the remote, undeveloped nature of the regions where peat is usually found, carbon monoxide (CO) levels are expected to be lower than the NAAQS's. Under the Prevention of Significant Deterioration (PSD) regulations, review will be required for $C 0$ emissions exceeding 100 tons per year in air quality attainment areas. NSPS for $C 0$ emissions do not exist for fossil fuel burning equipment, and there are no Federal emission standards for $\mathrm{CO}$ from petroleum refineries and fossil-fueled steam generators, with the exception of refinery catalyst regenerators. 


\section{ENVIRONMENTAL INTERESTS}

Environmental groups are expected to support the NAAQS for $C O$ in non-attainment areas and compliance with PSD increments in attainment areas for $\mathrm{CO}$.

ENV IRONMENTAL GOALS

Provide suitable control equipment for carbon monoxide emissions. Peat and peat-derived fuels should be burned in low-C0 emitting combustion equipment.

AC.TION MATA RFQిIIRFMFNTS

State - See Section 3.6.0

DOE

- Determine process units with the potential Co emissions.

- Identify low-CO emitting combustion equipment suitable for peat or peat-derived fuels.

- Project CO emissions for peat synfuels plants and develop appropriate control strategies.

- Determine the applicability of new source performance standards for peat facilities in conjunction with other Federal agencies.

AQ3.6.3 Nitrogen Oxides

\section{LEGISLATIVE/INSTITUTIONAL CONCERNS}

Ambient levels of nitrogen dioxide generally meet NAAQS's in peat-rich areas. oxidants, however, do exceed NAAQS's in urban areas near peatlands. In the 
future, nitrogen dioxide may be included in emission control strategies designed to control ambient oxidant levels. The individual State Implementation Plans (SIPS) are beginning to address this problem. 0xidants (along with TSP) are on the EPA's control priority list and PSD review is required for nitrogen dioxide emissions exceeding 10 tons per year. Similar NSPS for $\mathrm{NO}_{\mathrm{x}}$ from lignite-fueled steam generators and electric utility steam generators is 0.60 $\mathrm{lb} / \mathrm{milli}$ ion Btu. There are no emission standards specifically for synfuels plants; however, this is expected to change as commercialization occurs.

\section{ENVIRONMENTAL INTERESTS}

Environmental groups are expected to support the NAAQS for $\mathrm{NO}_{2}$ in non-attainment areas and compliance with PSD increments in attainment areas for $\mathrm{NO}_{2}$.

ENV IRONMENTAL GOALS

$\mathrm{NO} \mathrm{x}_{x}$ emissions from burning peat or peat-derived fuels should be minimized. $\mathrm{NO}_{x}$ emissions from fuel burning equipment at peat synfuels plants should be controlled through strategies incorporated into facility design.

ACTION/DATA REQUIREMENTS

State - See Section 3.6.0

DOE

- Monitor nitrogen oxide emissions from the laboratory and demonstration facility operations.

- Model dispersion of the projected nitrogen oxide air emissions for the near and far-field areas and determine potential impacts for Class I Areas. 
- Determine future air quality programs with respect to nitrogen oxide emissions and emission controls in conjunction with other Federal agencies.

- Characterize $\mathrm{NO}_{\mathrm{x}}$ emissions from combustion of peat or peat-derived fuels.

- Develop emission control strategies and estimate NOX emissions from peat synfuels plants.

AQ3.6.4 Sulfur Oxides

\section{LEGISLATIVE/INSTITUTIONAL CONCERNS}

Ambient air quality standards for particulate sulfate are being developed. The new NAAQS's could be more restrictive on emission sources than the current standards on gaseous $\mathrm{SO}_{2}$ since most of the emitted sulfur oxides are rapidly converted to condensed-phase particulate in the plume. NAAQS's for sulfur dioxide are met in almsot all peat-rich areas. PSD review will be required for facilities which predict sulfur dioxide emissions greater than 10 tons per year. The proximity of Class I areas to peat-rich areas may cause difflculties in ubtaining air quality related permits. PSD review is also required for sulfuric acid mist emissions exceeding one ton per year. NSPS for $\mathrm{SO}_{2}$ from steam generators is $1.20 \mathrm{lb} / \mathrm{million} \mathrm{Btu}$, but it is more complicated for electric utility steam generators, which require a $90 \%$ reduction when emissions are $1.0201 \mathrm{~b} / \mathrm{mi} 1$ lion $\mathrm{Btu}$ and a $70 \%$ reduction when emissions are less than $0.60 \mathrm{lb} / \mathrm{million}$ Btu.

More appropriate to peat synfuels plants are the NSPS for petroleum refineries, which limit emissions of $\mathrm{SO}_{2}$ trom sulfur recovery to $0.025 \%$ (al cero-percent oxygen) with continuous monitoring required. For comparison, the State of New Mexico limits coal gasification plant boilers to $0.16 \mathrm{lb} / \mathrm{million} \mathrm{Btu}$ for $\mathrm{SO}_{2}$ emissions. 


\section{ENVIRONMENTAL INTERESTS}

Environmental groups are expected to support the NAAQS for $\mathrm{SO}_{2}$ in non-attainment areas and compliance with PSD increments in attainment areas for $\mathrm{SO}_{2}$. Special interest in health effects of particulate sulfate has developed recently in conjunction with growing Natfonal and international interest in acid rain.

ENV IRONMENTAL GOALS

Peat combustion facilities should not be located in areas experiencing ambient $\mathrm{SO}_{2}$ problems or in areas with known adverse meteorological conditions that would result in ambient $\mathrm{SO}_{2}$ problems if new emission sources were introduced. $\mathrm{SO}_{\mathrm{x}}$ emission from burning peat or peat-derived fuels should be controlled to correct noncompliance with environmental requirements. Facility design should minimize $\mathrm{SO}_{x}$ emission from fuel combustion in synfuels plants.

ACTION/DATA REQUIREMENTS

State - Refer to Section 3.6.0

DOE

- Determine and model the $\mathrm{SO}_{2}$ emissions for various peat-sulfur concentrations obtained.through the laboratory and demonstration testing phases.

- Define the mechanisms of sulfur reactions throughout the fuel processing stages and determine the most applicable pollution abatement procedures.

- Conduct atmospheric dispersion analys is on the various $\mathrm{SO}_{2}$ emission factors:

- Consult with the appropriate federal agencies to determine new source performance standards for sulfur oxide emissions on synfuel plants. 
AQ3.6.5 Particulate Emission

\section{LEGISLATIVE/INSTITUTIONAL CONCERNS}

Total suspended particulates (TSP) are on the EPA's priority pollutant lists. Most areas in the U.S. have local or area wide violations of NAAQ's for TSP, including some peat-rich areas. Consequently, non-attainment and PSD must be reviewed. New standards for particulate sulfate and PAH (as well as other hazardous particulate pollutants) are imminent. PSD review is required for particulate emissions greater than 10 tons per year. The proximity of Class I areas to peat-rich areas may cause difficulties in obtaining air quality related permits. NSPS for particulates are $0.10 \mathrm{lb} / \mathrm{million}$ Btu from steam generators and $0.03 \mathrm{lb} / \mathrm{million}$ Btu from electric utility steam generators. There are no federal NSPS specifically for synfuels plants. However, New Mexico has formulated particulate emission standards for gasification plant boilers fueled with product gas of $0.03 \mathrm{lb} / \mathrm{mill}$ ion Btu and for gasification plants, themselves, of 0.03 grain/scf.

\section{ENV IRONMENTAL INTERESTS}

Environmental groups can be expected to support the NAAQs for TSP in nonattainment areas and compliance with PSD increments in attainment areas for TSP. Special environmental concern has developed for very fine particulates based on their carcinogenic properties and respiratory effects. Special size-related emission standards are currently being developed by the EPA.

ENV IRONMENTAL GOALS

Peat combustion facilities should not be located in areas experiencing ambient TSP level problems or in areas with known adverse meteorological conditions that would result in ambient TSP level problems if a new emission source were introduced. Particulate emissions from peat burning and peat-derived fuels should be controlled if they are not in compliance with environmental 
requirements. Particulate emission from peat synfuels plants should be controlled through facility design.

ACTION/DATA REQUIREMENTS

State - Refer to Section 3.6.0

DOE

- Collect particulate emission data for all SNG process permits.

- Cooperate with European countries to determine particulate emission rates and size analysis from commercial peat combustion facilities.

- Conduct air dispersion modeling on the emission data and selected i regional meteorological conditions:

AQ3.6.6 Non-Methane Hydrocarbon

\section{LEGISLATIVE/INSTITUTIONAL CONCERNS}

NAAQs for non-methane hydrocarbons (NMHC) are' exceeded in many urban areas. The main concern with non-methane hydrocarbons, however, is their contribution to oxidant formation. PSD review is required for emissions exceeding 10 tons per year because of photochemical production of ozone and other oxidants. NSPS for NMHC apply only to evaporation losses from storage tanks and not to emissions from combustion sources.

PAH's are coming under special scurtiny by the federal government because of carcinogenic properties, therefore, the government is developing strict standards to limit their release. 


\section{ENVIRONMENTAL INTERESTS}

Environmental groups can be expected to support the attainment of NAAQS for NMHC and ozone in non-attainment areas and compliance with PSD increments in attainment areas for NMHCs and. ozone.

ENV IRONMENTAL GOALS

Peat conversion facilities will probably not emit enough NMHC to create a significant problem. Emissions of NMHC's from storage vessles at peat synfuels plants should comply with environmental requirements. PAH emission from peat combustion and from peat synfuels plants should be in compliance with healthrelated requi rements.

ACTION/DATA REQUIREMENTS.

State - Refer to Section 3.6.0

DOE

- In cooperation with other federal agencies, determine work environment danger limits of $\mathrm{PAH} / \mathrm{NMHC}^{\prime} \mathrm{s}$. Determine where these concentrations could occur.

- Consult with the appropriate federal agencies to determinc the state of knowledge concerning the carcinogenic properties and fate of these substances .

- Conduct a review of all processes which produce. these products, and determine control technologies to protect the health of the inplant workers. 
- Conduct a health and risk analysis on research and commercial facilities. Comparable data can be obtained from current programs in coal gasification.

AQ3.6.7 Photochemical Oxidants

LEGISLATIVE/INSTITUTIONAL CONCERNS

Photochemical oxidants are a major cause of non-attainment status for air quality control regions. Photochemical oxidants will be included in PSD reviews. The PSD review criterion for NMHC, the precursor for photochemical oxidants, is 10 tons per year. NSPS include evaporation losses of NMHC from hydrocarbon storage vessels.

\section{ENV IRONMENTAL INTERESTS}

Environmental groups can be expected to support the NAAQS for ozone in nonattainment areas and compliance with PSD increments in attainment areas for ozone.

\section{ENVIRONMENTAL GOALS}

Photochemical oxidant levels are to be in compliance with the NAAQS by 1987. State Implementation Plans (SIPS) currently being revised to accommodate the 1977 Clean Air Act Amendments are to show how this compliance will be achieved. Peat combustion facilities are unlikely to contribute enough NMHC to affect ambient photochemical oxidant levels. However, $\mathrm{NO}_{\mathrm{x}}$ emissions might affect photochemical oxidation formation, depending on ambient air chemistry.

Emission of NMHC from burning peat and peat-derived fuels should be in compliance with environmental requirements. Evaporation losses from hydrocarbon storage vessels at peat synfuels plants should be in compliance with emission standards. 
ACTION/DATA REQUIREMENTS

State - Refer to Section 3.6.0

DOE

- Gather ambient ozone concentration data, growth projections, PSD increments, and meteorological from peatland regions.

- Determine the SIPs control methodologies for photochemical oxidants.

- Determine the NMHC emissions from burning peat and peat-derived fuels.

- Determine the evaporation losses from hydrocarbon storage vessels at peat synfuels plants and design specific emission control to be applied.

- In cooperation with European countries determine operating experience and data from peat fired facilities.

\section{AQ3.6.8 Metals}

\section{LEGISLATIVE/INSTITUTIONAL CONCERNS}

Current NAAQS include standards for lead with other metals being considered. PSD review is required for emissions exceeding one ton per year of lead, $0 . ?$ tons per year of mercury, and 0.004 tons per year of beryllium. No NSPS exists for metals from fossil fuel combustion. However, metal emissions are currently undergoing extensive regulatory review, and new standards are being considered. 


\section{ENVIRONMENTAL INTERESTS}

Airborne metals, in particular heavy metals, are receiving special attention from environmental groups because of potential toxic, carcinogenic, mutagenic, teratogenic, and other adverse health effects.

ENV IRONMENTAL GOALS

The environmental issue regarding metals emission should be researched in regard to the health and legal implications, and control strategies should be developed to prevent any environmental impact.: Peat synfuels plants should be designed to minimize emissions of metals into the air.

ACTION/DATA REQUIREMENTS

State - Refer to Section 3.6.0

DOE

- Determine metallic air emission from PDU and pilot plant operations and the amount of potential metals emitted into the water and solid waste streams.

- Gather operating experience and research from similar European facilities.

- Conduct mass balances for metals on all R\&D facilities.

- Determine metal concentrations in peat from selected regions.

- In cooperation with other federal agencies define limits and constraints. 
Table 4.8 South Carolina Peat Development Factors

(page 1 of 2 )

\section{PEAT RESOURCES}

Coastal counties incorporate most peatlands and are covered by a comprehensive state Coastal Zone Management plan.

Most peatlands are in private ownership.

Drainage of the areas for milied- or sod-peat production may be difficult.

Very little information is known concerning the quality, quantity, and location of the state's peat resources.

State is currently conducting DOE-sponsored resource analys is.

Little peat harvesting is currently conducted within the state.

\section{ENERGY DEVELOPMENT ATTITUDES}

The development and management of the South Carolina coast for natural recreational areas could be in conflict with peat resource development.

Peatland development would come under the policy decisions of the Coastal Zone Management Program and Coastal Council.

The state is currently developing an energy policy, but peat will not be incorporated unt il a full assessment is made. 


\section{ACTION/DATA REQUIREMENTS}

State - Refer to Section 3.6.0

DOE

- Determine reduced sulfur compound emissions from peat synfuel plants.

- Since downstream process equipment contributes to reduced sulfur compound emission, data can be readily accumulated from similar equipment operation in the petroleum industry.

AQ3.6.10 Nitrogen Compounds (Other than $\mathrm{NO}_{\mathrm{x}}$ )

LEGISLATIVE/INSTITUTIONAL CONCERNS

Currently PSD criteria and NSPS do not include nitrogen compounds. However, as an example of new regulations in the synfuel area, New Mexico has enacted coal gasification emission standards of $10 \mathrm{ppm}$ for hydrogen cyanide and $25 \mathrm{ppm}$ for ammonia.

ENVIRONMENTAL INTERESTS

Environmental groups can be expected to support emission regulations on hydrogen cyanide and ammonia.

ENVIRONMENTAL GOALS

Establish emission levels for nitrogen compounds for peat processing facilities to comply with environmental requirements. 
ACTION/DATA REQUIREMENTS

State - Refer to Section 3.6.0

DOE

- Since downstream processing equipment contributes to ammonia and hydrogen emission, data can be reviewed from operations of similar equipment in industry, such as petroleum refining equipment.

- Project nitrogen compound emissions from peat synfuels plants.

- Define emission control strategies to minimize these emissions.

- In cooperation with other federal agencies determine appropriate control strategies for nitrogen compounds:

\section{AQ3.6.11 Halogen Compounds}

\section{LEGISLATIVE/INSTITUTIONAL CONCERNS}

The PSD significant emission rate for flourides is 0.2 tons per year. New regulations by the. State of New Mexico has a standard of $5 \mathrm{ppm}$ for hydrogen chloride and hydrochloric acid from coal gasification plants.

\section{ENV IRONMENTAL INTERESTS}

Environmental groups can be expected to support emissions regulations on halogen compounds.

ENVIRONMENTAL GOALS

Establish emission levels for halogen compounds and minimize their release froin downstream equipment. 
ACTION/DATA REQUIREMENTS

State - Refer to Section 3.6.0

DOE

- From similar process equipment, determine the emission characteristics.

- Data should be accumulated on the operation of similar equipment in petroleum refineries and from current coal gasification and liquefaction programs.

- In cooperation with federal agencies, determine the vegetation that is sensitive to halogen compound emissions.

- In cooperation with state and federal agencies determine the halogen emission rates needed to protect sensitive vegetation and plant worker safety and health.

\section{AQ3.6.12 Visibility}

\section{LEGISLATIVE/INSTITUTIONAL CONCERNS}

The decrease of visibility in remote and pristine areas is a consideration in air polilution control regulations including NAAUS goals. Opacity limits required for fossil fuel combustion under NSPS are 20\% ( $27 \%$ for $6 \mathrm{~min} / \mathrm{hr}$ ). Photochemical oxidant control strategies are partially aimed at reducing visibility problems. No specific regulations exist for synfuels plants. In Class I areas, visibility reduction is receiving increased attention from the National Park Service's air quality division and has become a significant "problem in Western United States. 


\section{ENVIRONMENTAL INTERESTS}

Visibility has recently been given consideration in air pollution control goals. Environmental groups can be expected to support the attainment of visibility goals, especially in wilderness and remote areas of the country.

\section{ENV IRONMENTAL GOALS}

Emissions from peat combustion facilities are not expected to contribute enough NMHCs to contribute significantly to photochemical aerosol formation. Peat combustion facilities and synfuel plants should be located and designed to minimize adverse impacts on visibility.

\section{ACTION/DATA REQUIREMENTS}

State - Refer to Section 3.6.0

DOE

- Identify in local peatland areas where visibility reduction problems may occur due to nearby sources and local meteorological factors.

- Projections of visibility impacts of peat combustion facilities and peat synfuels plants should be made.

- Identify control strategies within the harvesting and processing areas to minimize adverse visibility effects.

- In cooperation with European countries examine operating experiences. on visibility problems raised by peat energy production. 


\section{AQ3.6.13 Water Vapor}

\section{LEGISLATIVE/INSTITUTIONAL CONCERNS}

Currently no national regulations cover water vapor emission. However, many energy siting regulations incorporate it in the overall site assessment.

\section{ENVIRONMENTAL INTERESTS}

Water vapor emissions are generally reviewed at the local level from the aesthetics standpoint. This issue is important within a pristine environment or adjacent to a Class I region.

ENV IRONMENTAL GOALS

Peat combustion facilities should not be located where meteorological conditions and downwind activities combine to produce adverse impacts from water vapor emissions or contribute to ice fog formation.

\section{ACTION/DATA REQUIREMENTS}

State - Refer to Section 3.6.0

DOE

- Identify peatlands where the water vapor emissions could pose significant impacts.

- Determine the potential sources of water vapor emissions from peat combustion and synthetic fuels programs. 
AQ3.6.14 Carbon Dioxide

\section{LEGISLATIVE/INSTITUTIONAL CONCERNS}

Currently there is no regulation concerning $\mathrm{CO}_{2}$ emissions. However, there is significant debate within the scientific and government communities on the impact of increased global $\mathrm{CO}_{2}$ concentration. New synfuel programs are receiving the most attention due to the release of substantial quantities during the - conversion process.

\section{ENVIRONMENTAL INTERESTS}

Environmentalists are concerned about a major synfuels program, which would possibly increase the atmospheric $\mathrm{CO}_{2}$ levels over a long term period.

\section{ENV IRONMENTAL GOALS}

The changes in atmospheric $\mathrm{CO}_{2}$ and its impact have not been determined. Consequently, until this question has been resolved, emissions from synfuel. should be limited.

\section{ACTION/DATA REQUIREMENTS}

State - Refer to Section 3.6.0

DOE

- Determine the peat development contribution to carbon dioxide.

- Define potential control strategies should carbon dioxide emission controls be implemented. 
AQUATIC ECOSYSTEM ISSUES

\section{AE 3.7.1 Fisheries}

\section{LEGISLATIVE/INSTITUTIONAL CONCERNS}

The protection of an area's fishery is the prime management objective of the state's water quality classification regulations and the land use permit procedures administered by the state and federal fish and wildlife services and regional river basin commissions. There are a myriad of state and federal laws and regulations to protect and promote fishery habitats from development. They encompass freshwatcr, lacustrine, and estuarine fishery resources. When the particular fishery has commercial, subsistance, or sport values, the resource management policies and analysis are more carefully scrutinized by the agencies. The parameters investigated in this fishery analys is would be any chemical, biological, or physical agents that could cause a negative fishery response. 


\section{ENVIRONMENTAL INTERESTS}

Many public groups such as the Isaac Walton League, Trout Unlimited, various sport fishing clubs, and freshwater and marine commercial fishing associations have an interest in promoting fishery resource development. Consequently, where there is a potential for disrupting the fishery, local and national organizations can be mobilized as pressure groups either to promote or vocally object to the proposed development. Where subsistance fishing is conducted by Indian and native populations, the protection of fishery resources has proven to be paramount in legal disputes.

ENVIRONMMENTAL GOALS

ACTION/DATA REQUIREMENTS

State

- Research existing data on the fisheries resources within the peatland areas as defined in Table 5.1.

- Collect unpublished observations and studies conducted in peat watershed areas on the fishery, use, habitat values, and ecosystem controls.

- Define the indigenious species within and'downstream of peatlands.

- Determine the commercial, subsistance, and public value of this fishery.

- Define the critical fishery habitats within and downstream of the peatlands.

- Define existing fishery management programs for peatlands.

- Define fishery migratory and nursery 'movement in and out of the peatlands and the immediate downstream areas. 
- Identify the occurrence and range of the areas protected rare and endangered fisheries populations.

DOE

- Through interagency agreements, define the fishery habitat values on federal peatlands.

- Prepare potential fishery impact analys is with the appropriate federal fishery resources and land managers.

- Define fishery usage and management objectives within federal peatland areas.

- In conjunction with other federal agencies, determine interaction of bog water quality on eggs, young, juveniles, and mature aquatic and estuarine fish species.

- Where specific energy plants have a high potential for development, conduct bioassays on specific natural bog discharges from a peat dewatering process: Conduct bioassays on the eggs, juveniles, and adults of the indigenous commercial, sport, and subsistance species.

- Determine the European experiences within this area of impact.

AE $3.7 .2 \cdot$ Food Web

\section{LEGISLATIVE/INSTITUTIONAL CONCERNS}

Regulations protecting aquatic trophic levels stem from the basic legislation protecting fishery resources. These laws recognize that the maintenance of lower trophic levels is essential to maintenance of the desired resource management objectives. Where potential impacts would be felt within the state coastal zones, the respective states Coastal Zone Management (CZM) policies 
would be expected to govern development. Inland-wetland protection laws, state fishery resource laws, and water pollution laws would be used to limit the introduction of contaminants into the aquatic ecosystem that would impact the aquatic foodweb.

\section{ENVIRONMENTAL INTERESTS}

Within southern and southeastern estuarine areas, commercial shellfish organizations would be expected to carefully analyze any potential impacts on commercial resources and be influential in the formulation of state policies. Where potential food chain impacts would be involved, environmental defense organizations would be expected to provide negative appraisals on the development.

ENV IRONMENTAL GOALS

ACTION/DATA REQUIREMENTS

State

- In general, there is very little specific research on this topic, consequently the states will have to rely on the professional judgement of the agency and university fishery specialists. It is expected, at. this phase of the program, that specific work tasks and studies will be proposed for future study efforts. The major objectives of this study should be to identify the major components of the foodweb and determine which species should be bioassayed. Later studies would perform these assays to determine organism responses to the projected physical and chemical stimulae.

- Review published and unpublished observations concerning natural and developed peatland discharges for areas foodweb relationships and interaction. 
- Determine by bioassay procedures any potential toxicological effects on eggs, larvae, juveniles, and adults of the key foodweb components that could be potentially impacted by peatland development.

DOE

- Confer with the appropriate federal agencies to provide a literature search and discussion papers on potential peatland development impacts on these estuarine and aquatic tropic levels.

- Conduct bioassay work on key indicator species of the different tropic levels.

\section{AE 3.7.3 Physical Interaction}

\section{LEGISLATIVE/INSTITUTIONAL CONCERNS}

There are many state and federal laws dealing with the protection and management of wetlands, floodplains, coastal zones, streams, and lakes. The enforcement of these statutes come under a number of state and federal agencies, such as Corps of Engineers, USDOI, USFWS, NOAA, CZM, EPA, River Basin Commissions, USDA, Soil and Water Conservation Districts, Forest Service, Water Resources Counsel, and other land management agencies.

\section{ENVIRONMENTAL INTERESTS}

The physical alteration and potential depletion of peatlands (wetlands) is considered a critical issue by all environmental groups. This issue has been broadly contested in the courts and is expected to be a fundamental challenge to the protection policies and goals of the national environmental groups and many federal and state agencies if sensitive peatland areas are selected for development. 
ENVIRONMENTAL GOALS

To minimize the physical changes in critical wetlands through proper siting of the resource and conversion facilities.

\section{ACTION/DATA REQUIREMENTS}

\section{State}

- Identify critical water courses and their habitats within the borders of a peatland that would restrict development of peat resources.

- Encourage state participation in policy formulation of peat development.

- Define critical nursery, or breeding areas which are used seasonally by aquatic organisms.

DOE

- Define areas where habitat improvement can be rendered during the harvesting and reclamation phases.

- Confer with the responsible federal water resource agencies to obtain statements and guidelines concerning potential peatland development and reclamation.

- Encourage an Interagency Task Force comprised of appropriate federal agencies managing the nation's water resources to deal directly with the complex wetland regulations and to formulate a generic Peat Development Program Implementation policy.

- Identify the federal public lands that could be considered for development. 
AE 3.7.4 Unique Aquatic Habitats

\section{LËGISLAT IVE/INSTITUTIONAL CONCERNS}

There are a number of state and federal environmental regulations that protect rare and endangered aquatic species.

\section{ENVIRONMENTAL INTERESTS}

Where development involves the potential disruption of rare and endangered species or unique and valuable aquatic ecosystems, local and national public awareness and sentiment against the development would be anticipated. Recent court cases have upheld the laws protecting ecosystems of rare and endangered flora and fauna, and, in many cases, it takes an act of Congress to change the federal government's position.

ENVIRONMENTAL GOALS

To identify and not disturb the habitat of any rare and endangered aquatic species.

ACTION/DATA REQUIREMENTS

State

- Define the range and habitat of all rare, endangered, and unique. aquatic species within the state that could be potentially found within the states peatland areas.

- Identify the data gaps in the above analyses and define a workscope fonr future studies in this area. 
DOE

- Coordinate with the states to specifically define the range and distribution of rare and endangered flora and fauna species in prime peat development areas.

- Define unique habitat areas within the prime peat development zones through consultation with local, state, and federal land and resource managers. 
Specific laws and regulations exist to protect threatened and endangered species, but no comprehensive law exists to protect wildlife and their habitats. However, numerous permit requirements of fish and wildife agencies, and the trend toward protection of coastal and inland wetlands by the federal and state governments dictates suitable methods for control of developments. In addition, a number of land classification regulations are available by the federal government to restrict access and development in key wilderness and monument areas.

\section{ENVIRONMENTAL INTERESTS}

Both local and national environmental organizations are expected to show concern about potential impacts of development of wildlife. It is obvious that the goals of wildlife protection vary among these groups. Sporting associations, such as Ducks Unlimited, are primarily concerned with protection of the 
wildlife population (waterfowl, moose, deer) that are in abundance enough to maintain recreational hunting, while the subsistence hunter in Alaska is concerned upon depletion of the wildlife population below seasonal levels. Other environmental parties are expected to be concerned over potential loss of wilderness and aesthetic, scientific, and recreational pleasures of observing wildlife in nature.

ENVIRONMENTAL GOALS

To minimize disruption of the wildlife population through the enactment of defined development policies proper planning of the peat development program, and selective development techniques.

\section{ACTION/DATA REQUIREMENTS}

A comprehensive assessment of peat development on wildlife population is required. General resource inventories can be obtained through literature searches and analysis of other developments in peatland and wetlands. There is a large body of information on the abundance and diversity of certain species in peatlands; but, very little research is available to determine site specific impacts. A number of management plans can be considered for protection of peatland species. These include the removal and transplanting of species to similar habitats, design of harvesting methods to compensate for wildlife requirements, and reclamation programs to enhance the habitat to encourage the return of wildlife.

State

- Classify the private, state, and federal peatlands to indicate high, moderate, and low terrestrial value and the conditions which the state would consider necessary to develop these respective categories.

- Define game management practices within peatlands. 
- Conduct a literature search on wildiife species that inhabit peatlands either permanently or seasonally; their abundance, diversity, food, and current survival pressure.

- From local contacts, research and literature searches, identify the key flora and fauna and their habitat requirements.

- Conduct the terrestrial environmental analyses as defined on Table 5.1.

- In conjunction with state fish, game and land management agencies, conduct initial terrestrial wildlife surveys of specific sites considered for development to determine their suitability.

- Establish policies for future wildlife management programs for reclaimed peatlands, including use of lands in various stages of development and considering buffer zones in and around the development.

- Through interagency agreement conduct a terrestrial resource inventory of federal peatlands.

- Establish development and reclamation criteria for federal peatlands.

- Determine the impacts of the Surface Mining Control and Reclamation Act on peat development.

- Determine if peat development is an option considered in the emerging Federal Land Use Management Policies.

\section{TE 3.8.2 Endangered Species}

\section{LEGISLATIIVE/INSTITUTIONAI, CONCERNS}

The federal government enacted the Endangered Species Act of 1973 to provide for the protection of threatened and endangered species. Under this act, 
federal agencies are prohibited from authorizing, funding, or carrying out actions, such as dam construction, timber harvesting, livestock grazing, and wetland dredging, that would jeopardize the continued existence of any endangered or threatened species or destroy or adversely modify its critical habitat. The act also requires that where additional species that are unique to their state have been identified the Department of Interior is required to provide consultations to other federal agencies on the impact of projects and programs of species. In addition, the Fish and Wilflife Service has established a recovery program for stabilization and enhancement of species.

The federal program is quite strong and has had major impact on a number. of large-scale energy projects, such as the Tellico dru New Melones Dams. In a number of cases, projects have been partially delayed because of discovery of endangered or threatened species during construction and later stages.

\section{ENV IRONMENTAL INTERESTS '}

The protection of threatened and rare species has been a principal goal of many national environmental interest organizations. The National Audubon Suciely, American Ornithologist Union, Nature Conservancy, National Wildlife Federation, and the Sierra club are just a few of the organizations that advocate the protection of threatened and endangered species. In addition to these national organizations, there are many state and local organizations that would be active in determining whether peatland development would jeopardize critical habitats and species.

\section{ENVIRONMENTAL GOALS}

Any development in peatlands must consider the existence and location of species. Consequently, siting of the energy facility should establish basic criteria that would avoid critical habitats, provide sufficient buffers to minimize contact and possible disruption of threatened and endangered species or institute recovery and enhancement programs. Special programs, such as 
reclamation, could be used to improve habitats for threatened and endangered species and to provide positive development benefits.

\section{ACTION/DATA REQUIREMENTS}

There is a fairly well defined mechanism available through the Department of Interior's Fish and Wildlife Service to determine the existence and habitats of threatened and endangered species. States also have additional listed species that have been determined to be threatened within the state boundaries. However, substantial field work on a site specific basis is necessary to verify the presence of listed threatened and endangered species and their habitats with the impact zones of a peat-energy development program. In all cases, to begin a meaningful study, alternate sites must be selected for survey.

State

- Document the occurrence of rare and endangered species within peatland areas.

- Define the state programs required for conducting field surveys for rare and endangered species.

- Identify current and future recovery programs.

- Define the critical habitat and presence of federal and state listed rare and endangered species within the state peatland areas.

DOE

- Through federal interagency agreements, conduct an initial analysis of potential threatened and endangered species and critical habitats within the peatland areas. 
- Through interagency agreements, define methods for conducting onsite flora/fauna evaluations to identify rare and endangered species.

- Incorporate enhancement programs that could be considered in the reclamation plans.

TE 3.8.3 Unique Peatlands

LEGISLATIVE/INSTITUTIONAL CONCERNS

There are a variety of regulations and land use policies presently used by federal and state governments to designate lands into specific protection categories. Currently, there is a trend in the federal government and, specifically, in the Department of Interior to identify lands needing special designation. Such programs as the National Natural Landmark, Wetland Protection Act, and the Threatened and Endangered Species Act provide a base for identifying peatlands of special interests.

\section{ENVIRONMENTAL INTERESTS}

$=$ In the last twenty-five years, there has been increasing public interest in preserving unique, rare, or ecologically significant occurrences of natural habitats of all types. Particular attention has been paid to natural areas threatened by proximity of civilization and further development. Swamps, marshes, bogs, etc., have become important in the public interest. The Nature Conservancy has participated with the U.S. Fish and Wildlife Service and other environmental interest groups in acquiring land for preservation.

ENV IRONMENTAL GOALS

Any development of peat resources must be located to avoid interference with unique peatland areas. 


\section{ACTION/DATA REQUIREMENTS}

To identify special interest peatlands, criterion must be developed by the environmental and scientific community. To insure that selected development areas do not contain or impact these areas, the following actions should be taken.

State

- Identify the unique peatlands or bogs which contain peat that have been designated within the state.

- Identify peatlands that are being considered for inclusion in either the national or state programs.

- Provide criteria for determining whether selected lands should be reviewed for classification.

DOE

- In cooperation with other federal agencies, define the unique and other general land use. classifications of federal peatlands. 
HEALTH AND SAFETY ISSUES

HS 3.9.1 Dust Explosions and Fires

LEGISLAT̄IVE/INSTIIUIIIONAL CONCERNS

Recommended practices for handling fine, combustible materials subject to dust formation have been developed for various industrial activities. Codes, including requirements for rupture disks for pressure-relief, govern most of these industrial activities. OSHA regulations also apply.

\section{PUBLIC INTERESTS}

Any explosion potential that poses a hazard to the public is expected to result in intense opposition to the project exhibiting the hazard. Labor unions would oppose any unsafe working conditions. 
HEALTH AND SAFETY :GOALS

The development of safe practices for the handling of dust-generating peat or peat products will be needed. An alternative would be to develop peat utilization technologies that eliminate dust fire and explosion hazards.

\section{ACTION/DATA REQUIREMENTS}

State - None.

DOE

- In conjunction with the appropriate Federal agencies, the combustion and explosion characteristics of peat dust and peat product dust should be determined so that safe threshold levels can be established. These safe threshold levels can then be used to develop safe practice guidelines.

- European dust supression and explosion prevention practices should be reviewed.

\section{HS 3.9.2 Peat Fires}

\section{LEGISLATIVE/INSTITUTIONAL CONCERNS}

Fire safety issues for drained peat bog harvesting and storage/stockpiling will be considered in the development of industrial practices and codes. Specific OSHA requirements for worker protection may need to be developed for largescale peat utilization, although general OSHA regulations may prove adequate. 


\section{PUBLIC INTERESTS}

Labor unions can be expected to oppose unsafe conditions and procedures. The public will oppose risks that can result in fires and the impacts of fires reaching beyond project boundaries.

HEALTH AND SAFETY GOALS

The prevention of peat fires, including bog fires and peat stockpile fires, is the primary goal. Fire detection and control systems are the secondary goal. ACTION/DATA REQUIREMENTS

State - None.

DOE

- Determine the conditions necessary for peat bog ignition, storage fires, and spontaneous ignition in conjunction with the peat development program.

- Develop fire prevention detection and control systems.

HS 3.9.3 Metal Carbonyls

\section{LEGISLÄTIVE/INSTITUTIONAL CONCERNS}

Occupational, Safety, and Health Administration (OSHA) standards for metal carbonyls have been established.

\section{PUBLIC INTERESTS}

Labor unions can be expected to oppose any working conditions that may expose workers to metal carbonyls. 
HEALTH AND SAFETY GOALS

Working health can be protected if conditions necessary for metal carbonyl formation are prevented or if adequate precautions are taken to prevent worker exposure, especially from accidents or maintenance operations.

ACTION/DATA REQUIREMENTS.

State - None.

DOE

- Investigate potential metal carbonyl formations in peat synthetic fuel facilities.

- Monitor PDU and pilot scale plants to develop occupational health and safety data.

- Through interagency actions, define the occupational and safety aspects of peat development.

HS 3.9.4 Trace Elements

LEGISLATIVE/INST ITUTIONAL CONCERNS

The Toxic Substance Control Act (TSCA) and the Resource Conservation and Recovery Act (RCRA) are the basis for the promulgation of regulations designed to prevent public exposure to hazardous trace elements.

\section{PUBL IC INTERESTS}

The public can be expected to support the efforts of Federal agencies to develop and enforce regulations intended to prevent public exposure to hazardous materials. 
HEALTH AND SAFETY GOALS

Peat products and waste products should be handled and disposed so that public or worker exposure to unsafe levels of trace elements is prevented.

ACTION/DATA REQUIREMENTS

State - None.

DOE

- Characterize and identify trace elements in peat products and peat energy waste products.

- Monitor PDU and pilot scale plants solid waste streams.

- Determine the reuse potential of all peat-related solid waste streams.

- Through interagency review, determine materials which will be regulated by the respective acts.

HS 3.9.5 Organic Carcinogens

\section{LEGISLATIVE/INSTITUTIONAL CONCERNS}

A Federal cancer policy has recently been developed to coordinate regulatory activities between various responsible Federal agencies. Procedures for determining carcinogenicity have been developed, and TSCA and RCRA regulations will determine safe handing and disposal of carcinogenic substances. 


\section{REGULATORY ISSUES}

\section{RI 3.10.1 Non-Attainment Regulations}

\section{LEGISLATIVE/INSTITUTIONAL CONCERNS}

Emission offsets (EO) regulations for new sources in non-attainment areas are being revised as the result of a recent. Federal court decision. State Implementation Plans (SIPS) will have to be revised to reflect those new Federal regulations. Some new sources will still have to provide EO's, but it is expected that only the very large new sources will be effected.

\section{ENV IRONMENTAL INTERESTS}

Environmental groups are actively opposing any relaxation in EO regulations in non-attainment areas. They are continuing their lobbying activities as new non-attainment regulations stemming from the recent Federal court decisions are being developed. 


\section{PUBLIC INTERESTS}

The public can be expected to continue to support the efforts of Federal agencies to develop and enforce regulations intended to prevent public exposure of carcinogens.

HEALTH AND SAFETY GOALS

Peat, peat-derived products, and waste products, should be checked for carcinogenicity and handled to prevent public or worker exposure if any carcinogens are found.

\section{ACTION/DATA REQUIREMENTS}

State - None.

DOE

- Identify and characterize any carcinogens in peat products and waste products.

- Monitor PDU and pilot plant process and waste streams to generate environmental and health and safety data.

- Conduct appropriate carcinogenic studies un suspected materials. 
ENVIRONMENTAL GOALS

Any development program must consider the regulatory constraints for the region. Compliance with these regulations involves siting, emission controls, and EO's.

ACTION/DATA REQUIREMENTS

State - Identify air quality non-attainment areas near peatlands.

DOE - Determine, as discussed in Chapter 3.6, peat energy facilities, air emissions, and assess the restrictive impact of proposed and developing E0 regulations.

RI 3.10.2 Prevention of Significant Deterioration

\section{LEGISLATIVE/INSTITUTIONAL CONCERRNS}

Prevention of Significant Deterioration (PSD) regulations are currently being revised following the federal court decision. Review requirements will not apply to small sources but can be expected to apply to Commercial SNG facilities. The allowable increments for new air emissions will be restrictive near Class I designated areas.

\section{ENV IRONMENTAL INTERESTS}

Environmental groups can be expected to work for redesignation of any remote area, especially with wildlife values, to Class I status. Many Indian reservations are showing some interest in Class I redesignation. Both of these interests are significant because of the proximity of peat-rich areas to Indian reservations and wilderness areas with wildlife vlaue. Environmental groups are actively opposing any relaxation in PSD regulations. 
ENVIRONMENTAL GOALS

PSD involves the compliance of any development program with regulations and involves siting, emission controls, and EO's.

\section{ACT ION/DATA REQUIREMENTS}

State - Monitor the SIP and trends within the state for redesignation.

DOE

- After the emissions have been determined from the various peat development options, the incremental air emissions should be compared to proposed and developing PSD regulations.

- Determination of Redesignations from Class II to Class I should be followed to see if they will preempt future peat energy development. If there is a conflict, plans for peat energy projects should be brought into the decision-making process during PSD redesignations.

RI 3.10.3 Hazardous Waste Regulation

\section{LEGISLATIVE/INSTITUTIONAL CONCERNS}

0il TSCA is not expected to impact peat energy development except, possibly, for solid or liquid fuel products. RCRA may have greater impact because of restrictive regulations affecting solid waste disposal. Wastes which are classified as hazardous will require special disposal facilities and longterm monitoring to detect fugitive losses to the environment.

\section{ENV IRONMENTAL INTERESTS}

Environmental interests can be expected to support strict regulations governing hazardous materials. Recent unfortunate and irresponsible practices have 
adversely affected the public, severely in a few instances, and have focused attention on these issues.

ENVIRONMENTAL GOALS

Hazardous waste regulations need to be developed that involve compliance of sitings, waste disposál practices, and monitoring requirements.

\section{ACT ION/DATA REQUIREMENTSS}

State - None.

DOE

- The chemical nature of peat energy products and wastes should be determined so that they can be classified according to guidelines published in regulations.

- Regulations affecting coal-conversion processes are currently being studied, and their applicability to peat development should be assessed.

\section{RI 3.10.4 Environmental Assessment Regulations}

\section{LEGISLATIVE/INSTITUTIONAL CONCERNS}

Currently, Federal Corps of Engineer Dredge and Fill Permits require an EIS under NEPA. RCRA may also require an EIS for waste disposal permits. If the 10 states reviewed the following states have their own environmental disclosure legislation:

Michigan

Minnesota

New York 
North Carolina

Wisconsin

\section{ENV IRONMENTAL INTERESTS}

Environmental interests can be expected to advocate the preparation of assessments and oppose Negative Determinations. The IES exposes the potential environmental impacts of a project to detailed public scrutiny. Long delays can result if serious impacts are identified or if the EIS is not thorough in its delineation of impacts.

\section{ENV IRONMENTAL GOALS}

A thoroughly detailed EIS should be prepared as early as possible for peat energy projects. Significant adverse impacts and environmental opposition should be identified early. Mitigation measures for significant adverse impacts should be incorporated into the project plans; many of these measures will be site specific.

\section{ACTION/DATA REQUIREMENTS}

State

- Clearly define the state permit requirements and ascertain the controls and requirements of the states surface mining regulations or peat energy development.

DOE

- Establish a concise environmental impact modeling capability and prepare a generic impact study which can serve as a basis for future peat development environmental evaluations. 
- Provide the initial forum for environmental impact scoping and define methods of impact mitigation. 
SOLID WASTE ISSUES

SW 3.11.1 Disposal of Organic Solid Waste Residues

LEGISLATIVE/INSTITUTIONAL CONCERNS

There are both federal and state regulations which cover the storage, handling, transport, and disposal of organic residues from peat processing.

ENVIRONMENTAL INTERESTS

Improper disposal of residue would generate local concern.

ENV IRONMENTAL GOALS

The goals of solid waste disposal programs that has substantial organic materials are to use organics on the site for site reclamation or to develop alternate products from the residues which can be exported from the site. 
ACTION/DATA REQUUIREMENTS

State

- Evaluate disposal practices in comparable industries such as forestry for application.

- Evaluate organic residue production from peat harvesting operation.

DOE

- In conjunction with other federal agencies, evaluate reclamation and disposal practices for organic residues.

SW 3.11.2 Disposal. of Slag and Fiy Ash

LEGISLATIVE/INSTI IUTTIONAL CONCERNS

Solid wastes generated from the process facility will be regulated by state and federal acts. Specifically, the Resource Conservation and Recovery Act, will require that waste generated be evaluated as to the degree of hazard they have if released in the environment. Different disposal requirements are defined according to the waste's hazard.

\section{ENV IRONMENTAL INTERESTS}

The growing concern of solid waste leachate problems impacting local surface and groundwater resources is well documented. Environmentally acceptable storage and disposal of all process solid wastes will be a checklist item for most environmental awareness would focus on this issue. 


\section{ACTION/DATA REQUIREMENTS}

For all proposed energy schemes, an inorganic mass balance should be conducted to define the concentration of inorganics in the solid/liquid streams and liquid solid energy. For all RD\&D functions, mass balances should be checked against the incoming peat source to account for all process emissions.

State - None.

DOE

- For all proposed energy conversion routes, innrganir. mass balance should be conducted to define the concentration of inorganics in the solid/liquid stream.

- Waste residues from pilot plant operations should be tested under the requirements of RCRA. 


\section{APPENDIX B - FEDERAL ENVIRONMENTAL LEGISLATION}

Legislation

National Legislation

Policy Act of 1969

(NEPA) PL 91-190

\section{Applicability to Peat Energy}

Environmental Impact Statements (EIS) must be prepared for all major federal actions significantly affecting the quality of the human environmental. Environmental Impact Assessments (EIA) are usually done to determine which actions require an EIS.

Clean Air Acts as amended Ambient air quality standards have been set to $\mathrm{SO}_{2}$ PL 91-604

as amended by

PL 92-157

PL 93-15

PL 93-319

PL 95-95 TSP, $\mathrm{NO}_{2}, \mathrm{CO}$, and $\mathrm{O}_{3}$; more are being considered. Affects all peat energy facilities.

New Source Performance Standards (NSPS) apply to coal-fired boilers and regulate $\mathrm{SO}_{2}, \mathrm{NO}_{2}$, and particulates. Lower emission levels are being considered, as are regulations for small particulates. Stricter standards specific to coal liquefaction may be forthcoming.

Standards for hazardous air pollutants limit mercury, beryllium, and lead emissions, and currently limit coal types that can be used for demonstration plants.

NSPS and regulations for the prevention of significant deterioration may affect plant siting. Nonattainment criteria may be extended to $\mathrm{NO}_{3}$, which could affect plant siting.

Best Available Control Technology (BACT) may be required for peat energy demonstration facilites. 


\section{Legislation}

Federal Water Pollution

Control Act Amendments

of 1972

PL 92-500

\section{Applicability to Peat Energy}

National Pollutant Discharge Elimination System (NPDES) permits are required to treat wastewater discharges.

Since effluent guidelines have not been developed for most fossil energy technologies, permit requirements are determined on a case-by-case hạsis hy states or hy EPA.

A "No Discharge" goal has been set for 1985.

Toxic Substances Control Act (TOSCA)

Disposal of specific materials used in peat energy processes may be regulated.

PL 94-469

Noise Control Act 1972

Control of ambient noise levels and recommended PL 92-574 standards for facilities regulated by state and local governments may be required in the near future.

National Historic Preservation Act of 1966

PL $89-665$

Federally financed, assisted, or permitted projects cannot impact important historic or culture sites unless no alternative exists.

Endangered Species Act PL. 93-205

Identification of endangered aquatic and terrestrial species at a potential construction site is required. May affect peat energy facility siting. 
Legislation

Fish and Wildlife

Coordination Act

PL 85-624

MOU-1967 DOD \& DOI

EO- 1977

Wildlife and Scenic

Rivers Act

PL 90-542

Coastal Zone Management

Act of 1972

PL 92-583

Rivers and Harbors Act

33 U.S.C. 401-413

Section of the 1899 Act

Marine Protection,

Research and Sanctuaries

Act of 1972

PL 92-532

Occupational Safety and Health Act (OSHA)

PL 9]-596

\section{Applicability to Peat Energy}

Any project requiring modification of bodies of water must be reviewed to prevent or reduce loss or damage to fish and wildi ife.

Controls permit action by Corps of Engineers:

Project must not degrade the quality of wildlife habitats and scenic rivers.

State coastal zone management plans developed with Federal financial assistance may affect siting and design of harvesting and conversion plant.

Permits are required for dredge and fill activities in navigable waters.

Projects must be integrated with flood control, river, and dam projects.

Permits are required for locating plants in wetlands areas, which may restrict extraction operaareal peat conversion plant siting.

Health and safety regulations must be met for workers in peat energy products. Noise levels for compressors, pumps, etc., are limited and must be controlled. Health regulations will be forthcoming. 
Legislation

Energy Reorganization Act of 1974

PL 93-438

Non-nucleàr Energy

Research and Development

Act of 1974 (Section 13)

PL 93-577

Resource Conservátion

and Recovery Act of 1976

PL 89-272

Floodplain Management

Executive Order 11988
Applicability to Peat Energy

DOE is required to ensure environmental acceptability of the fossil energy and other technologies under development.

Water availability assessments are required for demonstration and commercial plants; assessments are reviewed by Water Resources Council (WRC).

Sol1d waste disposal must cumply wilh musl slrigent air and water standards; monitoring is required; state or EPA permits required for all landfills by April 1, 1988; must comply with state programs for non-hazardous materials.

Designated to reduce as much as possible long and short term impacts associated wiPh floodplain development.

Requires each Federal agency to review policies concerning acquiring and managing Federal ' lands, federally regulated programs, and Federal activities affecling land use.

Reduce floodplain hazards and apply floodplain management practices.

Each agency will provide leadership and action to minimize the distruction and loss of wetlands and will conduct activities so as not to adversely affect land use and water resource planning efforts. 
Each agency must review possible alternatives and designate practicable measures to mitigate the impacts.

Protection and Enhancement of Environmental Quality Executive Order 11514 as amended by Executive Order 11911
The Federal government shall provide leadership in protecting and enhancing the environmental and quality of life.

Each agency must: monitor and evaluate its activities to protect the environment; develop procedures to issue public information on Federal plans and programs; develop research and demonstration testing programs; and engage in data and research exchange with other agencies.

Provides a mechanism for Federal and State review of all surface extraction of coal and other minerals (Peat may be considered to be a mineral).

Designed to issue and enforce regulations for the surface mining indust.ry, reduce environmental degradation, and force reclamation of a surface mine area.

The act declares that surface mining when conducted in an environmentally safe and diligent manner is a legally permitted activity. 


\section{Legislation}

Mineral Leasing Act

of 1920, as amended

by 30 USC 181

Safe Drinking Water Act

\section{Applicability to Peat Energy}

Provides the controls and regulation of surface and subsurface minerals extraction from Federal Public Lands.

Wastewater discharges may require additional treatment for heavy metals or organic waste if they impact drinking water supplies. 


\section{APPENDIX C}

\section{LIST OF PERSONS}

\section{CONTACTED DURING THIS}

STUDY

This Appendix contains the names, addresses, and telephone numbers of persons contacted during this study. 
NAME

Louis Reed

Keith Morehouse

Sharon Farna

Gilbert Key

Jackie Campbell

Dave Wesley

Charles Osolin

Bill Debord

Jan Lot.t.
AGENCY/ADDRESS

Bureau of Outdoor Recreation Office of Environmental Affairs Washington, D.C.

Refugee Planning \& Management Fish \& Wildlife Service Department of Irileriur Washington, D.C.

Publications Assistant Office of Biological Services Fish \& Wildlite Service $1730 \mathrm{~K}$. Street Washington, D.C.

Fish \& Wildlife Service Wet lands Coordinator Washington, D.C.

Ecological Services Division Office of Energy Operation U. S. Fish \& Wildlife Service 1375 K., Room 406

Washington, D.C.

Office of Endangered Species Fish \& Wildlife Service 1000 North Glebe

Arlington, VA

Public Affairs Office Council on Environmental Quality 722 Jackson Place, N.W. Washington, D.C. 20006

208 Coordinator Water Quality Planning EPA Region Chicago, IL

Environmental Review Environmental Protection Agency Washington, D.C.
TELEPHONE NO.

$202-343-5711$

$202-343-4047$

$202-634-4916$

$202-343-4034$

$202-343-6027$

$202=235-2760$

202-395-5770

$31 ?-35.3-? 155$

202-245-3006 
NAME

Merwyn Reed

Keith Miller

Frank Kelly

Richard Singleton

Samuel Aschuler

Dick O'conner

Wildon Barton

Jess Lunin

Bill Boring

Jim Swartz

Paul Cho
AGENCY/ADDRESS

U.S. Forest Service Division of Timber Management Washington, D.C. 20006

National Park Service Mining and Minerals Division Washington, D.C.

U.S. Dept. of Interior Office of Surface Mining Washington; D.C.

U.S. Dept. of Interior Mineral Surveys 2401 E. St., Columbus Plaza Wa shington, D.C.

U.S. Geological Survey Reston, VA 22092

Dept. of Commerce Office of Coastal Zone Management 2001 Wisconsin Ave. WashingP/I, D.C.

U.S. Dept. of Agriculture Energy Office Washington, D.C.

U.S. Dept. of Agriculture Agricultural Research Service (Soil and Water Group) Washington, D.C.

U.S. Dept. of AgricQlture Division of Lands Washington, D.C.

U.S. Dept. of Agriculture Beltsville, MD.

Department of Energy Environment Division Germantown, MD 20585
TELEPHONE NO.

$202-447-4052$

$202-234-2125$

$202-343-4264$

$202-634-1190$

$703-860-6649$

$202-634-4126$

202-447-2455

$202-344-3278$

$202-235-8107$

$301-344-2743$

$301-353-5897$ 


\section{CONTACT LIST (cont)}

NAME

Joe Maher

John Hagan

Clarissa Quinlan Director

Don Lyons

Don Markle

Dr. Bodo Diehn

Ralph Morgenweek

Dennis Asmunsen

\section{AGENCY /ADDRESS}

Department of Energyi Environment Division

Germantown, MD 20585

EPA Region IV

Environmental Impact Branch

Alaska Division of Energy and Power DevelkpmAnt

Alaska Dept. of Commerce and Economic Development 338 Denali St.

Anchorage, Alaska 99501

Principal Economist

Alaska State Division of Energy and Power Development

7th Floor McKay BIdg.

338 Denal i St.

Anchorage, AK 99501

Alaska Division of Energy and Power Development 338 Denali St.

Anchorage, AK 99501

Legislative Science Advisor

State of Michigan

P.0. Box 30036

Lansing, Michigan 48909

Biological Coordinator

U.S. Fish \& Wildlife Service

Federal Building

Fort Snelling

Twin Cities, Minn. 55114

Minnesota Peat Program

Division of Minerals

Dept. of Natural Resources

Box 45, Centennial Office Bldg.

St. Paul, Minn.
TELEPHONE NO.

301-353-5895

$404-881-7458$

$907-276-0508$

$907-276-0508$

$907-276-0508$

$517-373-2767$

$612-296-4807$ 
CONTACT LIST (cont)

NAME

Elon Verry

Anthony S. Earl

Robin Gates

Ronald Nicotera

Anita Sprenger

John Mogk

President

Bill Walden

Tom Segal.

Randy Harmson

Mr. Holder
AGENCY/ADDRESS

USFS Forestry Sciences Laboratory

North Central Forest Experiment

Grand Rapids, Minn. 55744

Wisconsin Dept. of Natural Resources

P.0. Box 7921

Madison, Wisconsin 53709

Division of State Energy

Room 201

1 West Wilson Street

Madison, Wiscons in 53702

Wisconsin Division of Resource Management 608-266-2625

Wiscons in DNR

Bureau of Environmental Impact

Box 7291

Madison, Wisconsin 53707

Wisconsin Geological Survey

1815 University Ave.

Madison, Wisconsin 53706

Michigan Energy \& Resource Research Association (MERRA) 1200 Sixth St.

Suite 328

Detrolt, Michigan 48226

Geological Survey of the Dept. of Natural Resources

Box 30028

Lansing, Michigan 48909

Michigan Energy Aministration

Dept. of Commerce'

P.0. Box 30004

Lansing, Michigan 48909

Milburn Peat Company

Box 236

La Porte, Indianna 46350
$608-263-7384$

TELEPHONE : NO.

$218-366-8571$

$608-266-2121$

$608-266-3427$

$608-266-0860$

$313-964-5030$

$517-373-1256$

$219-362-7025$ 
CONTACT LIST (cont)

NAME

AGENCY / ADDRESS

TELEPHONE NO.

Mr. Callom

Research Dept. of Michigan Public

$517-373-8690$

Service Commission

P.0. Box 30221

Lansing, Michigan 48909

Don Innman

Environmental Enforcement Division

$517-373-3503$

6th Floor, DNR Mason BIdg.

Lansing, Michigan 48927

Dr. William Cooper

Michigan Environmental Review Board

State of Michigan

Bux 30028

Lansing, Michigan 48909

Dr. Lindo Bartelli

Michigan Technological University

$906-487-2498$

School of Forestry

Houghton, Michigan 49931

Gail Melson

Legislative Science Advisor's Office

$517-373-2767$

State of Michigan

P.0. Box 30036

Lansing, Michigan 48909

Larry Witte

Water Division

Dcpt. of Natural Resources

State of Michigan

P.O. Box

Lansing, Michigan 48909

Dr. Paul Kindinger Marketing \& Trade Division

$517-373-1054$

Michigan Dept. of Agricultural

P.0. Box 30017

Lansing, Michigan 48909

Calvin Lutz

State Dept. of Agriculture

$517-373-1051$

State of Michigan

Dept. of Natural Resuurces

P.0. Box 30017

Lansing, Michigan 48909

Dr. Henry Webster

Forestry Division

$517-373-3930$

Michiyan Dept. of Natural Resources

$517-373-1275$

Chief

5 th Floor, Mason Bldg.

P.0. Box 30028

Lansing, Michigan 48909 


\section{CONTACT. LIST (cont)}

NAME

Johathan Cain

Marvin Cooley

David Jenkins

Chief

Raymond D. Schofield

Thomas R. Doyle

Herman Muskatt

Bod Denine

Vance Bryant
AGENCY/ADDRESS

Special Assistant to the Governor

Office of the Governor

State of Michigan

Lansing, Michigan 48909

Project Leader In Charge of Southern Michigan Peat

DNR Wildlife Division

P.0. Box 30028

Lansing, Michigan 48909

Wildlife Division

Michigan Dept. of Natural Resources

P.0. Box 30028

Lansing, Michigan 48909

DNR Wildlife Division

Stevens $\mathrm{T}$. Mason Bldg.

Lansing, Michigan 48909

Environmental Protection Specialist

Dept. of Natural Resources

P.0. Box 30028

Lansing, Michigan. 48909

Dept. of Geology

Utica College of Syracuse Univ.

Utica; NY 13502

NY State Geological Survey

Cultural Education Center

Room 3140

Empire State Plaza

Albany, NY 12230

NY Dept. of Environmental Conservation Land Resources Subdivision

Bureau of Minerals

Albany, New York 12233
TELEPHONE NO.

$517-373-3427$

$517-373-1263$

$517-373-1263$

$517-373-1263$

$517-373-1280$

$315-792-3134$

$518-474-5816$

$518-457-7480$ 


\section{CONTACT LIST (cont)}

NAME

Mark Bagdon

Orest Lewinter

John Cianci

Nancy Holmes Cowen Joel Davis

Gloria Lavasseur

Walter Anderson

James C. Bresee Director

Ralph Heath

David Jessup

John Marlar
AGENCY/ADDRESS

TELEPHONE NO.

NY State Energy Office

Division of Renewable Energy Resources Agency Building \#2

Rockefeller Plaza

Albany, NY 12223

NY State Dept. of Environmental Conservation

Bureau of F.nergy

RuUm 510

50 Wolf Road

Albany, NY 12233

NY Dept. of Environmental Conservation Bureau of Environmental Protection

Albany, NY 12233

Maine Office of Energy Resources

State House

Augusta, Maine 04333

Maine Land Use Regulation CoImissikn

State House

Augusta, Maine 04333

Bureau of Geology

Maine Dept. of Conservation

State House

Augusta, Maine 04333

North Carolina Energy Institute

P.0. Box 12235

Research Triangle Park, NC 27709

U. S. Geological Survey

Water Resource Division

P.0. Bux 2857

Raleigh, NC 27602

Technical Services

Dept. of Natural Resources

P.0. Box 27687

Raleigh, NC 276וI

EPA Region IV Water Division

Chief, Technical Support Branch

Atlanta, GA
207-289-2801

$518-474-7875$

$518-457-5915$

$518-457-2223$

$207-289-3811$

207-289-2631

$919-755-4510$

919-733-4058

404-881-3012 
Torgny J. Vigerstad Project Scientist

Buck Reed

Marsha Elder

Energy Specialist

\section{Bil.1 Partington}

Dale Walker

Jake Varn

Scott Pickrell

Mr. Woodward
South Carolina Energy Research Institute Suite 607, First National Bank Bldg. Maine at Washington Columbia, SC 29201

Wetlands Ecologist National Wetland Inventory

Fish and Wildlife Survey 9670 Execut ive Center Dr. Suite 217 Dade Building

St. Petersburg, FL 33702

Florida Environmental Regulation Commission 2600 Blairstone Rd. Tallahassee, FL 32301

Environmental Information Center of Florida Conservation Foundation Inc. 935 Orange Ave.

Winter Park, FL 32789

Florida State Energy Use Office Governor's Energy Office 301 Bryant office Tallahassee, FL 32301

State Office of the Secretary Florida Dept. of Environmental Regulation 2600 Blairstone Rd.

Tallahassee, FL 32301

Florida Soil \& Water Conservation Council

P.0. Box 1269

Gainsville, FL 32602

Florida Division of Resource Mgmt. State Lands Bureau 2600 Blairstone Rd. Tallahasee, FL 32301

$813-893-3624$

$904-488-4807$

$305-644-5377$

$904-488-6146$

$904-488-4807$

$904-376-1990$

$904-488-7500$

Director of Research \& Development Louisianna Dept. of Natural Resources P.0. Box 44156 Baton Rouge, LA 70893 
APPENDIX D

LETTER AND QUESTIONAIRE

This Appendix contains the Letter and Questionaire sent to the participating states conducting joint state/federal peat resource analyses. 
September 19,1979

TI-MC-025-014

Dear

UOP/SDC and Radian Corporation are cooperating in a joint study for the U.S. Department of Energy's Division of Fossil Fuel Processing. This study is intended to identify the major problems and issues that may occur from developing the nation's peat resources as alternate fuels or conversion to substitute natural gas. Since your office has been coordinating much of this effort for Minnesota, Dr. Melvyn Kopstein, DOE Peat Program Manager, requested that we obtain your assistance in surveying your state in order to identify quickly state and local agencies likely to be concerned with peat to energy development and responsible for determining the policies, plans, and environmental and socio-economic concerns from such development programs.

The initial objectives of this work are to identify and characterize environmental and socio-economic issues relative to the development of peat as an alternate energy source. Unce these issues are identified, they will serve as a basis for developing programs to resolve and ariswer them through DOE cooperative efforts with participating states and other federal agencies. Ultimately, DOE will be able to use the data which are collected through state participation in determining whether the peat program should become part of the National Fnergy Plàn.

We have enclosed a series of questions and topics which we feel will help us to identify concerned agencies and specific issues related to peat development. We are especially interested in key personnel in the state who have worked in peat-related areas. We feel at this time, you are the most capable person to contact the appropriate agencies and personnel. 
TI -MC-025-014

Page 2

If possible, we would like the answers to these questions to be brief and be submitted back to our office during the week of October 1, 1979.

The following state agencies or organizations should be contacted to determine their knowledge and interest in the peat development issues.

o. Agriculture

- Environmental Conservation

- Governor and Legislature Energy Advisory Boards or liaison personnel

- Geological and Mineral Survey

- Forestry

- Fish and Wildlife Services

o. Public Utility Commission

- Bureau of Mines

- Water Conservation/Natural Resources

- Governor or Legislative Panels on Environmental Affairs

The basic inquiries are to determine:

I. Major issues involved in development of peatlands.

II. Current and potential agency attitudes and policies with regard to development of peatlands.

III. State agency permit mechanisms for assessing peatlands for development.

IV. Qualitative estimate of the peatland resource.

v. Inique envirnnmental features and problems associated with state peatland development.

VI. Mgency awareness of potential development issues. 
TI -MC-025-014

Page 3

We look forward to working with you in this study. The information that you provide on the state will help to clarify the critical issues in peat development and provide a more coherent program for DOE to pursue with respect to its alternate fuel strategy.

If you have any questions regarding the study, please do not hesitate to call me or Dr. Kopstein. We intend to develop a close contact with your office to assure free flow of information. I will be contacting you in the next couple of days to discuss the questions and purposes in more detail.

Thank you for your assistance.

Sincererely,

Enclosure 


\section{EXAMPLES OF QUESTIONS \& TOPICS FOR STATE AGENCIES}

\section{A. ENERGY}

1. Does the state have a comprehensive energy development plan?

2. Has peat utilization been considered as an element of the energy development plan?

3. How does state policy on energy incorporate peat development?

4. What is the state's policy on development of energy resources within the state?

5. What legislative means or programs are available to control or encourage peat development should a policy be developed to utilize peat for energy purposes within the state?

6. What has the state determined to be the significant issues in developing its energy resources and specifically peat.

B. RESOURCE

1. What is the current knowledge on the type, extent, and distribution of peatlands in the state?

2. Have the peatlands and peatbogs of the state been inventoried either by state or industry?

3. What agencies are in charge of developing the resource inventory?

C. LAND USE

1. Are there state and federally owned peatlands and if so, what agencies are responsible for administering them?

2. How are peatlands identified within the state; agriculture, forestry, wet lands, undeveloped, etc.

3. Does the state Land Use Commission have defined policies on peatlands?

4. Are there peatlands involved in future development plans not specific to the use of peat, i.e., clearing and stripping of land for mining beneath peat, and conversion of peatlands to agriculture?

5. Are peatlands and peatbogs protected by state regulations, legislative titles, or other methods? 
6. Where are the state wildlife reserves, state owned lands, state forest reserves, parks, wilderness; or other defined resource management areas? How would development of peatlands be controlled by existing regulations covering other resource management areas?

7. Where are the federal designated wildlife refuges, national forest, parks, wilderness areas, and other defined national resource management areas?

8. Does the state have lands purchased through cooperative agreement with the federal government? If so, what are the stipulations of land on or near such lands?

9. Are there forest products currently being harvesting from peatlands? What i.s the acreage and quality of the product?

\section{REGULATORY/POLICY}

1. Has any state agency developed management policies or strategies for the use of peatiands, especially in the context of large scale extraction of peat?

2. What agency would acquire the leasing and regulatory authority, if large scale peat development occurs?

3. What agencies are concerned with peat development and which one would be considered the lead in developing state policies? Are there interagency committees established to come to a state consensus on peat development policy?

4. Does the state have a land use planning commission that covers the development and protection of lands within the state?

5. Does the state have a major project siting program?

6. Which agency of the state monitors the horticultural and agricultural peat industry and how is the program administered?

\section{[. ENVIRONMENTAL}

1. Do existing environmental regulations cover potential peatlands development or will snerific regulations and controls need to be promulgated?

2. Does the state have a wetland protection act?

3. Does the state have a wetland classification system?

4. Does the state have a coastal zone managément plan?

5. What are the current state environmental policies regarding peatland development? 
6. Does the state have a peatland or wetland reclamation policy?

7. Does the state have an environmental impact statement requirement and how is the applicability of the development to EIS determined?

8. Is there a state surface mining control regulation that covers the extraction of peat?

\section{F. RESLARCH}

1. Are there commercial or research projects in the state that are involved in utilizing peatlands for agriculture, forestry, treatment of sewage effluent, erosion and buffer control around other industries, and associated drainage of peatlands.

2. What research has been conducted on water quality and hydrology of peatlands and subsequent affects from development of peat lands?

3. Have there been any studies on health effects of the release of materials from peatlands?

\section{G. PUBLIC INTEREST}

1. What specific environmental and public interest organization would be involved in the peat development program?

2. What process is available in the state for public participation in the planning and decision making process on peat development? How do state, local, and regional interest enter into a comprehensive peat development pran? 
APPENDIX E

REFERENCES

$E-1$ 


\section{REFERENCES}

1. Bay, R. R., Evapotranspiration From Two Peatland Watersheds. Paper presented at General AssembTy of Bern., 1967, pages 300-307.

2. Bay, R. R., Factors Influencing Soil-Moisture Relationships in Undrained Forested Bogs. International Symposium on Forest Hydrology, The Pennsylvania State University, Pennsylvania, Pergamon Press - Oxford and New York, 1966, pages 335-343.

3. Bay, R. R., Runoff From Small Peatland Watersheds. Journal of Hydrology 9. Amsterdam: North Holland Publishing Co., 1969, pages 90-102.

4. Bay, R. R., Techniques of Hydrologic Research in Forested Peatlands, USA. Sertion 11, XIV IUJFRO - KONGRESS, Monchen, 1967, pages 400-415.

5. Bay, R. R., The Hydrology of Several Peat Deposits in Northern Minn., USA. Third International Peat Congress, pages 212-218.

6. Boelter, D. H., Drainage Experience in Lake States and Northern European Peatlands. pages 167-175.

7. Boelter, D. H., Hydraulic Conductivity of Peats. Soil Science, Vol. 100, No. 4, USA, 1964, pages 227-231.

8. Boelter, D. H., Hydrologic Characteristics of Organic Soils in Lakes

States Watersheds. Vol. 21, No. 2, Journal of Soil and Water Conservation, 1966, pages 50-53.

9. Boelter, D. H., Important Physical Properties of Peat Materials. Third International Peat Congress, pages 150-154.

10. Boelter, D. H., Physical Properties of Peat as Related to Degree of Decomposition. Presented to Division S-6, Soil Science Society of America, 1969, pages 606-609."

11. Boelter, D. H., The Hydrologic Characteristics of Undrained Organic Soils in the Lake States. Madison, Wisconsin: Soll Science Society of America, Inc., 1974, pages 33-46.

12. Boelter, D. H., Water Storage Characteristics of Several Peats in situ. Vol. 28, No. 3, Madison 11, Wisconsin: Soil Science Society of America Proceedings, 1964, pages 433-435.

13. Boelter, D. H., Water Table Drawdown Around an Open Ditch in Organic Soils. Vol. 15/4, Repr. 275, Journal of Hydrology, pages 329-340.

14. Boelter, D. H. and Blake, G. R., Importance of Volumetric Expression of Water Contents of Organic Soils. Vol. 28, No. 2, Madison 11, Wisconsin: Soil Science Society of America Proceedings, 1964, pages 176-178. 
15. Boelter, D. H. and Close, G. E., Pipelines in Forested Wetlands. Vol. 72, No. 9, Journal of Forestry, 1974, 3 pages.

16. Boelter, D. H. and Verry, E. S., Peatland and Water in the Northern Lake States. General Technical Report NC-31, St. PauT, Minn.: USDA Forest Service, 1977, 22 pages.

1\%. Brooks, Kenneth N. and Predmore, Steven R., Phase 2 Peat Program - Hydrologic Factors of Peat Harvesting. Minneapolis, MN: Department of Forest Resources, College of Forestry, University of Minnesota, May 1978.

18. Brown, J. M., The Effect of Overstory Removal Upon Surface Wind in a Black Spruce Bog. Research Note NC-137, St. Paul, Minn.: USDA Forest Service, 1972,2 pages.

19. Cameron, C. C., Peat Deposits of Northeastern Pennsylvania. Washington, D.C.: Geological Survey BulTetin 1317-A, 1970, 90 pages.

20. Cameron, C. C., Peat Deposits of Southeastern New York. Washington, D.C.: Geological Survey Bulletin 1317-B, T970, 32 pages.

21. Cameron, C. C., Peat Resources of the Unglaciated Uplands Along the Allegheny Structural Front in West Va, Maryland, and Pennsylvania. Washington, D.C.: Geological Survey Professional Paper 700-D, 1970, pages D135-D139.

22. Cameron, C. C., Some Peat Deposits in Washington and Southeastern Aroostook Count ies, Maine. Washington, D.C.: Geological Survey Bulletin उ317-C, 1975, 40 pages.

23. Cameron, C. C., United States Mineral Resources - Peat. Geological Survey Professional Paper 820, pages 505-513.

24. Campbe11, R. N., Letter to Professor Robin regarding Peat Resource Update. Kingston 7, Jamaica: First Colony Farms, Inc., May 14, 1979, 3 pages.

25. Cederstrom, D. J., Boswell, E. H., and Tarver, G. R., Summary Appraisals of the Nation's Ground-Water Resources - South Atlantic-Gulf Region. Washington, D.C.: Geological Survey Professional Paper 813-0, 1979, 35 pages.

26. Conklin, Martha H., The Potential Air Quality Impacts of Harvesting Peat in Northern Minnesota. Document P-4107. Concord, MA: Environmental Reseach and Technology, Inc., August 1978.

27. Cowardin, L. M., Carter, V., Golet, F.C., and LaRoe, E. T., Classification of Wetlands and Deep-Water Habitats of the U.S. Fish and Wildlife Service, TAn Operational Draft), 1977, 100 pages.

28. Crawford, R. L., Effects of Peat Utilization on Water Quality in Minnesota. Minneapolis, MN: University of Minnesota, March 1978. 
29. Davis, C. A., The Possible Use of Peat Fuel in Alaska. Washington, D.C.: Geological Survey Butletin 442-B, pages 63-66.

30. Davis, J. F. and Lucas, R. E., Organic Soils, Their Formation, Distribution, Utilization, and Management. Michigan Agricultural Experiment Station, Special Bulletin 425, 1959, 155 pages.

31. Davis, R. 0. and School, W., Ammoniation of Peat for Fertilizers. Vol. 77, No. 1996, Bureau of Chemistry and Soils, U.S. Department of Agricultures, 1933, 3 pages.

32. Dixon, R. M., Bay, C. E., and Peterson, A. E., Drainage of a Peat Soil Overlying an Artesian Aquifer. Research Report No. 21, University of Wisconsin, April 1966, 12 pages.

33. Dyal, R. S., Physical and Chemical Properties of Some Peats Used as Soil Amendments. Vol. 24, No. 4, SolT Science Society of America Proceedings, 1960, pages 268-271.

34. Elling, A. E. and Verry, E. S., Predicting Wind-Caused Mortality in Strip-cut Stands of Peatland Black Spruce. Grand Rapids, Minn.: The Forestry Chronicle, Oct. 1978, pages 249-252.

35. Farnham, R. S. and Boelter, D. H., Minnesota's Peat Resources: Their Characteristics and Use in Sewage Treatment, Agriculture, and Energy. A National Symposium on Freshwater Wetlands and Sewage Efflucent Disposal, May 1976, Ann Arbor, Michagan: The University of Michigan, 1976, pages $241-255$.

36. Finn Energy '79. Specialized Energy Technology From Finland. Director General, Energy Department Finnish Ministry of Trade and Industry. Technical Research Center of Finland 02150 ESPO 15 Finland.

37. Fleischman, William A., Peatland Policy Study. Minnesota: Minnesota Department of Natural Resources, JuTy 1978.

38. Fox, Robin, Malterer, Thomas and Zarth, Randee, Inventory of Peat Resources in Minnesota. Progress Report. Minnesota: Minnesota: Minnesota Department of Natural Resources, Division of Minerals, January 1977.

39. Fraser, J. A., Fuel Peat Transport and Materials Handling. Presented at the Canadian Peat Symposium. Fredericton, New Brunswick, August 16-17, 1979.

40. Geophysical. Survey Systems, Inc., Radar Assessment of Peat Resources. Hudson, NH.

41. Hammond, J. S. Alaska Power and Fconomic Development Program. Appendix, Department of Commerce and Economic Development, 1978, 238 pages.

42. Hammond, J. S., Jobs and Power for Alaskans. A Program for Power and Economic Development, 1978, 100 pages. 
43. Heath, R. C., Hydrology of the Albemarle-Pamlico Region North Carolina. U.S. Geological Survey, Water Resources Investigations, 9-75, 1975, 98 pages.

44. Huels, Frederick W., B.S., The Peat Resources of Wisconsin. Economic Series No. 20, Madison, Wisconsin: Wisconsin Geological and Natural History Survey, 1915, 274 pages.

45. Institute of Gas Technology, Current Trends of U.S. Energy Consumption. Chicago, IL: Energy Topics, 1979, 5 pages.

46. Institute of Gas Technology, Experimental Program for the Development of Peat Gasification. Interim Report No. 5. United States Department of Energy, February 1979.

47. Institute of Gas Technology, Experimental. Program for the Development of Peat Gasification. Interim Report No. 6. United States Department of Energy, March 1979.

48. Institute of Gas Technology, IGT Forecast of U.S. Energy Consumption in 1977. Chicago, IL: Energy Topics, February 14, 1977.

49. Institute of Gas Technology, Peat and the Environment. Chicago, IL: January 1979.

50. Institute of Gas Technology, U.S. Fossil Fuel Resources. Chicago, IL: Energy Topics, 1977, 2 pages.

51. Institute of Gas Technology, Conference Proceedings Management Assessment of Peat as an Energy Resource. Conference held at Arlington Va, JuTy 1979.

52. Institute of Gas Technology, World Nonrenewable Energy Sources. Chicago, IL: Energy Topics, 1979,5 pages.

53. Institute of Gas Technology gaScope, Peat: Second Largest U.S. Fossil Fuel Resource. No. 41, Winter 1977-1978, 4 pages.

54. International Peat Society, Combustion of Peat. Proceedings of the Symposium of Commission II, Kuopio, Finland, T975, pages 8-13.

55. International Peat Society, Peat Industry, Proceedings of the Symposium of Commission II, Kouvola, Finland, 1978

56. Kurmis, Villis, Hansen, Henry L., Olson, Hohn J. and Aho, Allan R., Phase IIPeat Program Forestry - Plant Communities Report. Minnesota: Minnesota Department of Natural Resources, May 1978.

57. Laboratory Techniques of Measuring Water Storage Properties of Organic SolTs. Vol. 28, No. 6, Madison 11, Wisconsin: Soil Science Society of Timerica Proceedings, 1964; pages 823-824. 
58. Lagowski, James P., Peat - A Michigan Fuel Resource? Report No. 76-28, Detroit, Michigan: Detroit Edison, December, 1976.

59. Lagowski, James P., Peat Utilization in Finland. Report No. 77-24, Detroit, Michigan: Detroit Edison, September, 1977.

60. Lovering, T. G., Lead in the Environment. Washington, D.C.: Geological Survey Professional Paper 957, 1976, 90 pages.

61. McDowe 11, L. L., Stephens, J. C., and Stewart, E. H., Radiocarbon Chronology of the Florida Everglades Peat. Vol. 33, No. 5, Madison, Wisconsin: Soil Science Society of America Proceedings, 1969, pages 743-745.

62. Maki, Wilbur R., Laulainen, Leonard A., and Meagher, Patrick D., SocioEconomic Effects of Peat Resource Development in Northern Minnesota. St. Paul, MN: Department of Agriculture Experiment Station, University of Minnesuta, Máy 31, 1978.

63. Marshall, William H. and Miquelle, Dale G., Terrestrial Wildlife of Minnesota Peatlands. St. Paul, MN: Minnesota Department of Natural Resources, May 1978.

64. Meagher, Patrick D., Maki, Wilbur R., and Laulainen, Leonard A., Economic Effects of Minnesota Peatiand Development. Minnesota: Minnesota Department of Natural Resources, February 1979.

65. Midwest Research Institute Center for Peat Research, Socioeconomic Impact Study. Minnesota Gas Company, March 1, 1977.

66. Minnesota Department of Natural Resources, Minnesota Peat Program Legislative Status Report. Minnesota: Minncsota Statc Lcgislature, Apri1 1379.

67. Minnesota Department of Natural Resources, Minnesota Peat Program Policy Report. Management Goals and Objectives and Policy Alternatives. Minnesota: Minnesota State Legislature, April 1979.

68. Minnesota Department of Natural Resources, Peat Program 1978-1979 Biennium Legislative Appropriation. Progress Report No. 5 Minnesota: Minnesota State Legislature, January $19 / 9$.

69. Minnesota Department of Natural Resources, A Report on European Peat Terhnology, May 1976.

70. Moore, P. D. and Bellamy, D. J., Peatlands. New York, NY: Springer-Verlag New York Inc., 1974.

71. Murray, R. G., Production of High Value Solid Fuels from Cellulosic Feed Materials by the Koppelman Process. Menlo Park, CA: SRI International, 1979, 17 pages.

72. Murray, R. G., Stable High Energy Solid Fuel From Lignite. Paper 47e, Menlo Park, CA: SRC International, 1978, 22 pages. 
73. Othmer, D. F., Peat for Power. Combustion, Polytechnic Institute of New York, 1978, pages 44-47.

74. Phililips, R. C., Koppelman, E., and Murray, R. G., Upgrading Lignite by the Koppelman Process. Houston, Texas: SRI International, 1978, 15 pages.

75. Radforth, N. W. and Brauner, C. 0., Muskeg in the Northern Environment in Canada. University of Toronto Press, 1977.

76. Radian Inc., Harner, D., Socioeconomic Issues Associated with Use of Peat as an Energy Source. DCN 79-217-151-17-01, 19 0ctober 1979.

77. Robinson, W. 0. and Dever, R. F.; Composition of Soils, Peats, and Plants Associated with Cattle Malnutrition. Vol. 82, No. 4, United States Department of Agriculture, 1956, pages 275-285.

78. Scholl, W. and Davis, R. 0., Ammoriation of Peat for Fertilizer. Vol. 25, Industrial Engineering Chemistry, October 1953, pages 1074-1078.

79. Singleton, R. H., Mineral Commodity Summaries. 1979, pages 110-111.

80. Singleton, R. H., Peat. Reprinted from Bureau of Mines Minerals Yearbook, United States Department of the Interior, 1977, 10 pages.

81. Sixth International Peat Congress. Information Bulletin No. 1, Duluth, Minn., 1979, 5 pages.

82. Soper, E. K. \& Osbon, C. C., The Occurrence and Uses of Peat in the United States. USGS Bulletin 728, 1922.

83. Stoeckeler, J. H., Drainage Along Swamp Forest Roads. Vol. 63, No. 10, Journal of Forestry, 0ct. 1965, pages 772-776.

84. Stoeckeler, J. H., Size and Placement of Metal Culverts Critical on Peatl and Woods Roads. Research Note NC-37, St. Paul, Minn.: U. S. Forest Service, Aug. 1967, 4 pages.

85. Stoeckeler, J. H., Wetland Road Crossings: Drainage Problems and Timber Damage. Research Note NC-27, St. Paul, Minn.: U. S. Forest Service, Apri1, 1967,4 pages.

86. Suoninen, A., A Short Review of the Use of Fuel Peat in the World. Helsinki, Finland, 3 pages.

87. Terry, J. E., Hosinan, R. L., and Bryant, C. T., Summary Appraisals of the Nation's Ground-Water Resources - Lower Mississippi Region. Washington, D.C.: Geological Survey Professional Paper 813-N, T979, 41 pages.

88. The UNESCO Press IAHS, Hydrology of Marsh-Ridden Areas. Paris, 1975, Proceedings of the Minsk Symposium, June, 1972, 562 pages. 
89. The U.S. Geological Survey and the U.S. Bureau of Mines, Mineral Resources of the Appalachin Region. Washington, D.C.: Geological Survey Professional Paper 580, 1968, 492 pages.

90. Argonne National Laboratory, Regional Energy-Environment Data Book Draft. ANL/EES-TM-25, 1978, 844 pages.

91. U.S. Department of Energy, Fuel Use Act. DOE/EIS-0038, Washington, D.C.: Final Environmental Impact Statements.

92. U.S. Department of Interior, Energy Perspective 2. 1976, 224 pages.

93. U. S. Department of the Interior, Mineral Industry Surveys. Washington, D.C.: Bureau of Mines, 1978, 1 page.

94. U.S. Department of the Interfor, Mineral Industry Surveys. Washington, D.C.: 1979, 10 pages.

95. Utilizing Peat as a Fuel, Feasibility Study for the DNR State of Minnesota Report No. UE 68380 EKONO Inc., October 1977.

96. Verry, E. S., Some Tentative Thoughts to Manage the Scale of Peatland Development. Based on Water Quality Considerations Only. Dec. 14, T978, I page.

97. Verry, E. S., Streamflow Chemistry and Nutrient Yields from Upland-Peat land Watersheds in Minn. Ecology, Vo1. 56, No. 5, 1975, pages 1149-1157.

98. Verry, E. S. and Boelter, D. H., The Influence of Bogs on the Distribution of Streamflow from Small Bog-Upland Catchments. Hydrology of Marsh-Ridden Areas, Paris, 1975: Proceedings of the Minsk Symposium. Unesco Press, June 1972, pages 169-178.

99. Verry, E. S. and Elling, A. E., Two Years Necessary For Successful Natural Seeding In Nonbrushy Black Spruce Bogs. Research Note NC-229, St. Paul, Minn.: USDA Forest Service, 1978, 3 pages.

100. Vigerstad, Torgny J., Cohen, Arthur and Abbott, William, Peat Resource Estimation in South Cárolina. First Qudrlerly Report. south Carolina: South Carolina Energy Research Institute, October 31, 1979.

101. Walden, W. A., Michigan Peak Reserves. Geological Survey Division, Unedited Draft, T976, 21 pages.

102. Wildlife Management Institute, Proceedings of the National Wetland Classification and Inventory workshop. FWS/0BS-76-09, Washington, D.C.: Fish drld Wildlife Service, 1975,110 pagcs.

103. Zenone, C. and Anderson, G. S., Summary Appraisals of the Nation's Ground-Water Resources - Alaska. Washington, D.C.: Geological Survey Professional Paper 813-P, 1978, 28 pages. 
104. Assessment of the Technical and Economic Feasibility of Peat Resource Development in Northern Saskatchewan Communities. Canada: Department of Regional Economic Expansion, Department of Energy, Mines and Resources, Department of Mineral Resources, March 1979.

105. Salmgren, 0., Exploitation of Peatlands and Its Consequences on the Ecology, Climate, and Hydrology of the Peatland Area, NTIS, Technical TransTation SNV PM1048, Aug. 1979.

106. Proceedings of the National Wetland Protection Symposium, FWS/0BS-78/09, Reston, VA: Fish and Wild Tife Service, 1977, 255 pages.

107. Johnson, B. V., Connor, K., and Swan, S. A., An Environmentally Sound Peat Harvesting Technique. Presented at the 40th Annual Mining Symposium, Duluth, Minn., 1979, pages 2-14.

108. Kopstein, M., Peat Prospectus. U. S. Department of Energy, Division of Fossil Fuel Processing, July 1979.

109. Dachnowski and Stokes, Peat Resources in Alaska. USDA Technical Bulletin, No. $769,1941$.

110. Otte, L. J. \& Ingram, R. L., Quarterly Progress Report, Peat Resources in North Carolina. October 1979.

111. State of South Carolina, Coastal Zone Management Program DEIS. United States Department of Commerce NOAA, 1979.

112. Our Nations Wetlands. An Interagency Task Force Report coordinated by Council on Environmental Quality, 1978.

113. Davis, J. H., The Peat Deposits of Florida - Their Occurrence, Development, and Uses. Florida Geological Bulletin, No. 30, 1946.

114. Brupacher, Sedburg, Wiltes, Coastal Marshlands of Louisiana and Chemical Properties of the Soil Properties. LSU Ag Exp Sta, 1968.

115. Chabreck, R. H., Vegetation and Water Soil Characteristics of Louisiana Coastal Region. LSU Ag Exp Sta, Bulletin 664, 1972.

116. Frazier, Asanik, Elsik, Environments of Peat Accumulation. Paper presented at Gulf Coast Lignite Conference held by Bureau of Economic Geology, Austin, Texas, June 1976 . 
APPENDIX $F$

GLOSSARY OF TERMS

F-1 


\section{GLOSSARY OF TERMS}

Adsorption - Adhesion of the molecules of a gas, liquid, or dissolved substance to a surface.

Aeolian - of the wind; used in reference to wind-borne particles, etc.

Anadromous - Going up rivers to spawn; said of salmon, shad, etc.

Anaerobic - With reference to decomposition, occurring in the absence of air or free oxygen; with reference to microbes, able to live and grow under those conditions.

Anthracite - The oldest form of coal. It is hard and black, burns with little smoke, and has a heating value above $14,000 \mathrm{Btu} / \mathrm{lb}$.

AQCR - Air Quality Control Region.

Aquifer - A layer of porous rock, sand, etc., usually underground, from which significant quantities of groundwater can be extracted. An aquifer may be unconfined, in which case it is underlain by an impervious layer of rock or clay; or it may be confined, in which case it is encased on all sides by impervious material and secures recharge water at its end.

Artesian well - A well drilled into a deep aquifer in which water pressure is high enough to force water to the surface through the drill pipe.

Ash Content - The incombust ible mineral content of a fuel.

BACT - Best Available Control Technology.

Bacterial Fixation - Microbial oxidation and reduction processes that result in the transformation and synthes is of organic and inorganic compounds.

Base flow - The amount of flow in a surface stream that is contributed by groundwater. 
Bench Scale - A processing unit used to test a concept in a laboratory.

Bioassay - A technique for determining the biological effects of a substance by measuring its effects on a test specimen against those of a standard substance.

Bioconversion - Conversion of a substance into a different substance through biological action.

Biogasification - Conversion of liquid or solid matter into a gas by digestion of the matter by microorganisms.

Biomass - The total amount of living organisms in a particular area or volume.

Biota - The plant and animal life of a region.

Bituminous - A coal, younger than anthracite, that yields pitch or tar when it burns and produces much smoke and ash; heating values range between 10,500 and $14,000 \mathrm{Btu} / \mathrm{lb}$. It is the most common coal.

BOD - Biochemical 0xygen Demand, a measure of the biodegradable material in water determined by incubating a water sample and measuring the decrease in dissolved oxygen as bacteria decompose the material.

Bog - A peat-covered or peat-filled area, generally with a high water table, dominated by mosses, especially sphagnum. Trees may or may not be present. Although the water table is often close to the surface, usually there is little standing water. Typically the upper peat and bog waters are strongly acid.

Briquette - When used in reference to peat, a small brick-shaped mass made up of compressed fine particles of peat.

Btu - (British Thermal Unit) the amount of heat required to raise the ternperature of one pound of water one degree Fahrenheit. 
Bulk Density - The mass per unit bulk volume of a dry material.

Cation - A positive ion.

CEQ - Council on Environmental Quality.

CO - Carbon monoxide.

$\mathrm{CO}_{2}$ - Carbon dioxide.

Coalesced Domes - Subarctic bogs developed through the lateral growth and joining of adjacent domed peatlands.

Coal Rank - A classification of coal according to one of its characteristics. A common system classifies coal according to its age. In this system, the four major coal classes are (in descending order of age) anthracite, bituminous, subbituminous, and lignite. The American Society for Testing and Materials uses a combination of characteristics in its ranking system: coals having a fixed carbon content about $69 \%$ are ranked by fixed carbon content, those having a lower fixed carbon content are ranked by Btu content.

Coastal Zone Management Agency - An agency of the U.S. Department of. Commerce established to manage the U.S. coastal zones.

Co-current - A flow of process materials in the same direction.

COD - Chemical 0xygen Demand, a measure of the amount of oxidizable chemicals in water determined by chemical oxidation of a water sample with dichromate or permanganate.

COE - Corps of Engineers. 
Colloidal - Adjectival form of the word colloid, which is a substance comprised of insoluble particles so fine that they will not settle out from suspension and are extremely difficult to filter. All living matter contains colloidal material.

Conterminous - Contained within the same boundaries or limits. The conterminous United States includes all states except Alaska and Hawai

COS - Carbonyl sulfide.

Counter-current - A flow of process materials in opposite directions.

Cross-flow - A flow of process materials at right angles to each other.

$\mathrm{CS}_{2}$ - Carbon disulfide:

CZM - Coastal Zone Management.

CZMP - Coastal Zone Management Program.

Degree of Decomposition - A quantity the value of which is usually approximated by measuring a chemical or physical characteristic that changes with the breakdown of organic materials. With increasing decomposition in peat, the size of organic particles decreases, resulting in smaller pores and more dry material per unit volume.

Depressed Bog - A bog the surface of which is lower than the surrounding terrain.

Dewatering - The process of removing water from peat.

DOE - The U.S. Department of Energy.

DOI - The U.S. Department of the Interior. 
Ecosystem - A system made up of a community of animals, plants, and bacteria and its interrelated physical and chemical environment.

EIA - Environmental Impact Assessment.

EIR - Environmental Impact Report.

EIS - Environmental Impact Statement.

Fn - Fimission offset.

EPA - Environmental Protection Agency.

Estuary - An inlet or arm of the sea, especially the wide mouth of a river, where the tide meets the current. The adjectival form is estuarine.

Eutrophication - Increased nutrient enrichment of a body of water, resulting in promotion of aquatic plant growth.

Evapotranspiration - The total water loss from the soil caused by direct evaporation and by transpiration from the surfaces of plants.

Fen - A peatland dominated by grasses, sedges, and reeds, often with some shrub cover and a scanty tree layer. The water table is at the surface most of the time. Waters and peats are less acidic than in a bog.

Fibric - A peat composed primarily of partially decomposed sphagnum and other mosses (also called sphagnum peat). It has a low degree of decomposition, is reddish brown to dark reddish brown in color, and has a $\mathrm{pH}$ ranging from 3.5 to 4.5 .

Fixed Carbon - The solid combustible materials remaining after volatile materials have been expelled from a solid fuel by heat. 
Flyash - Airborne particles of ash resulting from direct combustion.

Food Web - All the individual food chains in a community (also called food cycle). A food chain is a sequence (as grass, rabbit, fox) of organisms in a community in which each member of the chain feeds on the member below it.

FWPCA - Federal Water Pollution Control Act.

g/dscm - Grams per Dry Standard Cubic Meter.

Gasification - Conversion of a solid fuel to gaseous form by burning it in the presence of air or oxygen and steam.

gr/dscf - Grains per Dry Standard Cubic Foot.

Groundwater Recharge - Replenishment of depleted groundwater, either naturally. by percolation of surface water or aritificially from basins or injection wells.

Habitat - The region where a plant or animal naturally grows or lives; native environment.

Harvesting - Extraction of peat from a bog.

Heating Value - The heat content of a fuel, usually expressed in Btus per pound or (for gases) in Btus per standard cubic foot.

Hemic - A peat consisting principally of partially decomposed reeds, marsh grass, cattails, and associated plants. It has a medium degree of decomposition, is dark reddish brown to black in color, and has a $\mathrm{pH}$ between 4.0 and 5.5 .

$\mathrm{H}_{2} \mathrm{~S}$ - Hydrogen Sulfide. 
Hydrogasification - A gasification process in which peat or coal is reacted with hydrogen to form methane.

Hydrogenation - The process of increasing the hydrogen content of a substance through chemical reactions.

Hydrological Budget - An accounting system used to keep a record of the various components of the hydrological cycle.

Hydrological Regime - The hydrological properties of a site or region.

Hydrological Cycle - The constant circulation of water from the sea and land to the atmosphere and back from the atmosphere to the sea and land.

Hydrophilic - Capable of taking up or uniting with water.

Interflow - Unsaturated groundwater flow.

Interstitial Water - Water contained in small crevices within a substance.

Lacustrine - of or pertaining to, or growing in, lakes.

Lignite - A soft, brownish-black coal younger than bituminous and older than peat. Heating values range from 6,300 to 8,300 Btu per pound on a moisture, ash filled basis.

LNG - Liquid Natural Gas.

M - Symbol for thousand.

MAF - Moisture and Ash Free.

Marsh - Grassy wet places, with little peat accumulation and much standing or slowly moving water. The tree layer is scanty or not present. Waters are not acid. 
Min - Minimum.

Minerotrophic - Nourished by mineral water; refers to peatlands that receive nutrients from mineral groundwater (i.e., groundwater that has previously percolated through a mineral soil and extracted minerals from it).

MM - Symbol for million.

Muck - Soil containing a high percentage of well decomposed organic matter.

Muskeg - A term derived from Algonquin, meaning "peatland", used by Canadian scientists to include any area covered by more than a foot of peat.

MW - Megawatt.

NAAQS - National Ambient Air Quality Standards.

NEPA - National Environmental Policy Act.

NESHAP - National Emission Standards for Hazard Air Pollutant.

NIOSH - National Institute of Occupational Safety and Health.

NMHC - Non-Methane Hydrocarbon.

NO - Nitrogen Oxide.

NOX - Nitrogen Oxides.

NO? - Nitrogen Dioxide.

NOAA - National Oceanic and Atmospheric Administration.

NSPS - New Source Performance Standards. 
Ombotrophic - Nourished by rain; refers to peatlands dependent on nutrients from precipitation.

OSHA - Occupational Safety and Health Act.

Overburden - Vegetation overlying a peat deposit.

PAH - Polynuclear Aromatic Hydrocarbon.

PDU - Proçess Development Unit, a unit larger than bench scale in which one operation of a process can be tested.

Peat - A water-saturated organic soil consisting largely of organic residues formed as a result of incomplete decomposition of its plant constituents under anaerobic conditions. The physical and chemical properties of the peat depend mainly on the nature of the plants from which it originated, the properties of the water in which the plants were growing, and the moisture relations during and following its formation and accumulation.

$\therefore$ Peat-fuel - Harvested and dewatered peat ready for use as fuel.

Peat Horizon - The top liyer or small thickness of peat.

Pellet - A small ball or rounded mass of peat.

Permafrost - Permanently frozen subsoil.

pH - A symbol for the degree of acidity or alkalinity of a solution. A pH value of 7 indicates a neutral solution; $\mathrm{pH}$ values from 0 to 7 indicate decreasing acidity, and values from 7 to 14 indicate increasing alkalinity.

Pilot Plant - A test unit, larger than a PDU, in which the integrated operations of a process can be tested. 
Plateau Domes - A well developed bog having the form of a large flat plateau with relatively steep marginal slopes.

Pocosin - A low, swampy region of the coastal plain of the southeastern United States, typically having extensive stands of pond pine and a thick undergrowth of evergreen shrubs. Although the topography appears unusually flat and featureless, pocosins are commonly slightly dome-shaped and sometimes have lakes in their higher central portions.

Porosity - The ratio of the volume of voids of a material to the volume of its mass.

ppm - Parts per million.

Proximate Analysis - An analysis of a solid fuel to determine its content of volatile matter, moisture, ash, and fixed carbon.

PSD - Prevention of Significant Deterioration.

Pyrolysis - Chemical decomposition of a substance by heat in the absence of air.

Raised Bog - A nutrient-poor peatland that has grown above its site of origin. Its center is above its edges and its surface is. convex. Its water is supplied chiefly by rainfall.

Reclamation - The act of converting a harvested peatland to a form that will serve some useful purpose, as to farmland, forest, or wildlife habitat.

RCRA - Resources Conservation and Recovery Act.

Riverine - On or near the banks of a river.

ROW - Right Of Way. 
Saltwater Intrusion - Invasion of saline water into fresh groundwater. This occurs most commonly in coastal aquifers, where seawater moves inland if groundwater levels decline. Salt water can also move upward into fresh groundwater aquifers underlain by saline water in any location if water is pumped from wells that are too close to' the freshwater-saltwater interface.

Sapric - A highly decomposed form of peat having less than $33 \%$ fiber. It is shapeless, brownish black to black in color, and moderately acid ( $\mathrm{pH} 4$ to $5.5)$.

sctd - Standard Cubic reet per Vay.

SDWA - Safe Drinking Water Act.

Semiemergent - Descriptive of a body of land that is partially covered by water, so called because some of the higher land features emerge from the water.

SIP - State Implementation Plan.

Slurry - A mixture of solids and a liquid in which there is far more liquid than solids, usually described by stating the percentage of solids. A $3 \%$ slurry, for example, contains $3 \%$ solids, $97 \%$ liquid.

SNG - Substitute Natural Gas.

Socioeconomic - Of or involving both social and economic factors.

Solvent Extraction - Removal of desired components from a substance by immersing the substance in a liquid solvent that dissolves some components more than others.

$\mathrm{SO}_{\mathrm{X}}-$ Sulfur Oxides. 
$\mathrm{SO}_{2}$ - Sulfur Dioxide.

$\mathrm{SO}_{3}$ - Sulfur Trioxide.

Sphagnum - Any of a genus of highly absorbent, spongelike, grayish mosses found in bogs; peat moss.

Swamp - Type of wet forested peatland nourished by water containing minerals. A swamp is intermittently to permanently covered by water and has more than $25 \%$ tree cover of species that reach at least pulpwood size.

Thermal 0xidation - Incineration.

Tiaga - Russian name for a semicratic vegetal complex associated with a forested muskeg environment.

TSCA - Toxic Substances Control Act.

TSP - Total Suspended Particulates.

Tundra - Any of the vast, nearly level, treeless plains of the arctic regions.

Ultimate Analysis - Analysis of a solid fuel to determine its content of carbon, hydrogen, sulfur, nitrogen, ash, and oxygen. An ultimate analysis may also be carried further to determine the content of other materials.

USDA - United States Department of Agriculture.

USFWS - United States Fish and Wịldife Service.

USGS - United States Geological Survey.

Volatile Matter - Those products (exclusive of moisture) that are given off as gases when a solid fuel is heated under specified conditions. 
Wet Carbonization - A process in which the percentage of fixed,carbon in a peat is increased through removal of oxygen to which the carbon has been bonded.

Wetlands - General term, broader than peatland or muskeg, used to name any poorly drained tract whatever its vegetational cover or soil.

Windrow - A row of material, as harvested peat, hay, or grain, brought together to dry before being processed further. 